DEPARTMENT OF THE INTERIOR

UNITED STATES GEOLOGICAL SURVEY

GEORGE OTIS SMITH, DIRECTOR

BULLETIN 455

\title{
COPPER DEPOSITS
}

OF THE

\section{APPALACHIAN STATES}

BY

WALTER HARVEY WEED

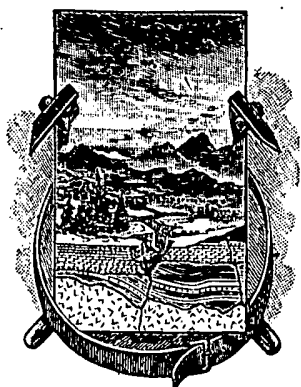

ים

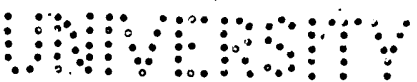

WA S H I N GTON

GOVERNMENT PRINTING OFFICE

1911 


$$
\begin{aligned}
& \text { QE. } 15 \\
& \text { RO } \\
& \text { Copy } 2
\end{aligned}
$$

$$
\text { צ' }
$$




\section{CONTENTS.}

Introduction- Page.

Classification of deposits:- 10

Types discriminated._-_- 10

Ducktown type_._...-_-_-_-_ 11

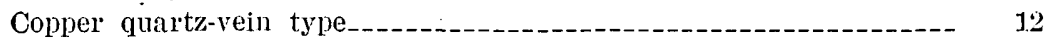

Carolinian type

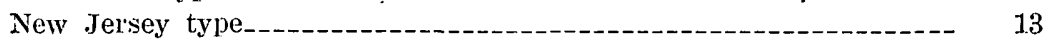

Pahaquarry type-_-_- 13

Blue Ridge or Catoctin type

Occurrence and character of the ores_-_-_-_-_-_-_-_-_-_-_ . 15

Origin of ores of the Blue Ridge type

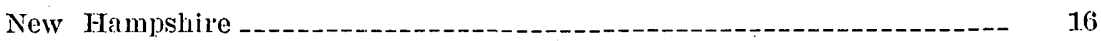

Gatrdners Mountain mines

Warren mine -

Milan mine _-_._- 1.8

Lyman mine _-_.

Vermont_-_-_-_-_.

Features of deposits

Geologic relations._._.

Ore deposits -

General character-_-_- 20

The ores

Origin of the deposits

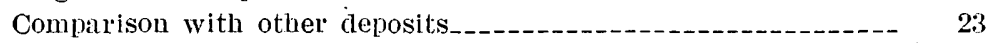

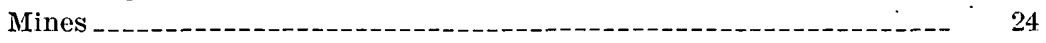

Copperfield or Ely mine (Vershire mine) _-_-_-_-_-__-_._-_-_ 24

History

Production

Development_-_-_. 25

Reduction works_-_-_-_-_._- 25

The ores.

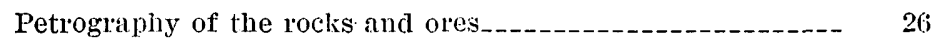

Minerals of the rocks_._- 26

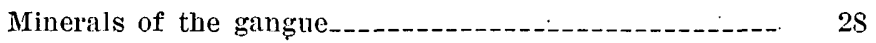

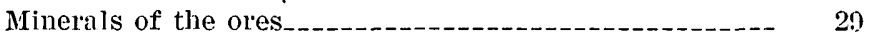

Formation of the ores._- 30

Elizabeth mine_....- 30

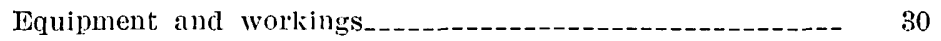

The ores_-_-_-_- 31.

Corinth mines -...- 32

Union mine-_-_-_- 82

Eureka mine 
Tasachusetts . . Page.

Davis mine

Other deposits

Connecticut__. 35

Occurrence and character of ores____ 35

Hartford County deposits_._. 35

Simsbury (Newgate) mines._._. 35

Higley mine

Bristol mine-.._- 36

New Haven County deposits__._. 37

New York _. 38

New Jersey _.

Historical notes

Geologic relations of the deposits_____ 39

Ore deposits _. 40

The ores -

Mines _-_.

Condition _._. 42

Schuyler mine _._._- 42

Griggstown mine

Location _. 42

Geologic relations _._._. 43

The ores___ 44

American mine _..._-_-_- 45

Workings and equipment______._. 45

Ore deposits _. 45

Character and relations

The ores _. 48

Genesis of the oreś_-_. 50

Pahaquarry mine _._._- 54

Exploitation _. 54

Geologic relations _... 55

Ore deposit__._. 55

Development__._._- 57

Pennsylvania__._______ 57

South Mountain region___._. 57

Northern coal region _._. 59

East-central region.___. 61

Copper mined with other metals

Maryland_______- 62

Western belt_:- 62

Middle belt

Eastern belt.

Virginia__-_-_-_-_-_-_-_-_- 65

Distribution of the ores____ 65

Piedmont region___- 67

Virgilina district._._. 67

Location._. 67

Fistory

Rocks___-_._. 69

General features____-_._. 69

Microscopic character._. 71

Chemical composition 
Virginia-Continued.

Piedmont region-Continued.

Virgilina district-Continued.

Rocks-Continued. Page.

Age relations,

Conclusions__._-

The ores_-_-_-_-

Veins

Mines _. 79

Holloway mine

Person Consolidated mines._._- 81

Wall mine____._._. 82

Chappel mine

Copper World mine

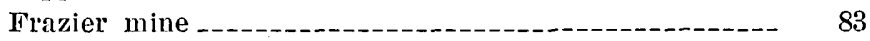

Thomas mine -.-_. 83

Anaconda mine

Blue Wing mine_-_._- 84

High Hill mine

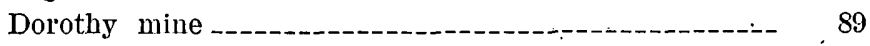

Albemarle County (Southwest Mountain) -____-_-_-_-_-_-_ 89

Triassic area (Loudoun, Culpeper, Orange, and Amherst counties) $\quad 92$

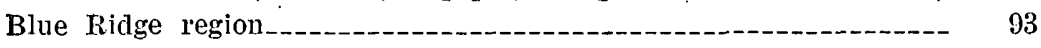

History --

Geology -

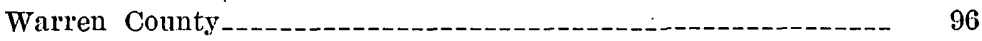

Structural relations_-_-_-_-_-_-_- 96

Front Royal district____- 97

Deposits near Linden_-_-_. 97

Sealoch mine_-_-

Dickeys Ridge district.-_-_-_-_- 99

Mills property (Cove farm) - 99

Rudacill property-_-_- 100

Bentonville-Overall district_-_-_-_-_-_-_-_-_-_-- 101

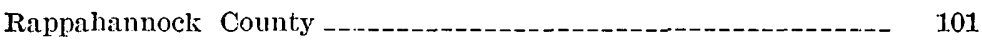

Ambler property

Manassas Gap mine-_-_-_-_-_-_-_-_-_-_-_-_-_-_- 102

Page County _-_- 104

Geology -

Mine near Ida_-_-_-_-_-_-_-_-_- 106

Madison County _...-_- 107

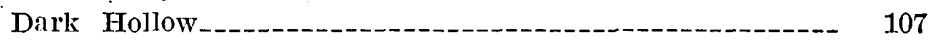

Hawksbill Mountain_-_-_-_-_-_-_-_-_-_-_-_-_-_-_- 109

Stonyman Mountain

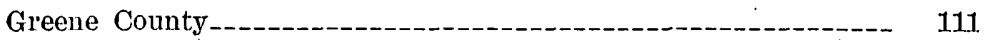

Hightop Mountain property

Piedmont Copper Company's property--_-_-_-_-_-_-_-_ 113

Summary of Blue Ridge ores______- 114

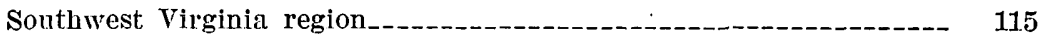

Introduction_-_-_-_-_-_-_-_- 1115

Geology -

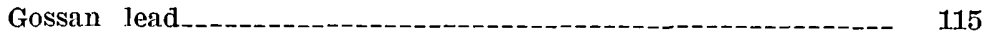

General character-_-_-_-_-_-_- 115

Character of the ore 
Virginia-Continued.

Southwest Virginia region-Continued.

Gossan lead-Continued.

Page.

The mines____ 121

Features of the vein__-_-_-_-_-_ 121

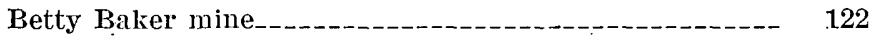

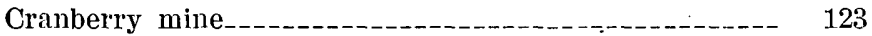

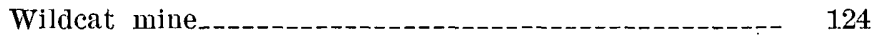

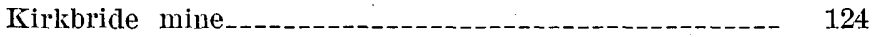

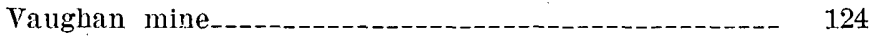

Vein southwest of Vaughan mine_-_____-_._-_-_-_-_- 124

Future of the Gossan lead_-_-_-_._- 124

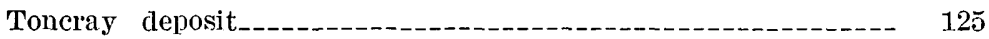

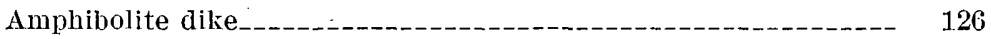

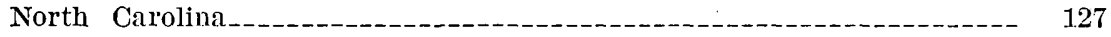

Character and exploitation of the depesits__-_-_-_-_-_-_-_-_-_-_-_ 127

Ashe and Allegheny counties__-_- 128

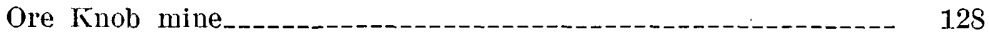

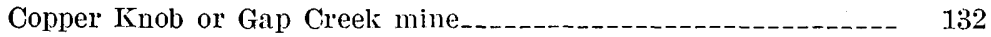

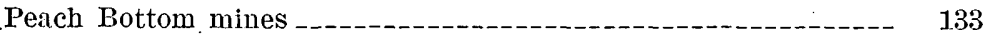

Elk Knob -...-

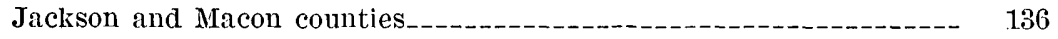

Important properties _-_- 136

Cullowhee mine -.-.-...- 138

Little Tennessee mine

Nantahala mine -._-_-_-_-_-_._- 140

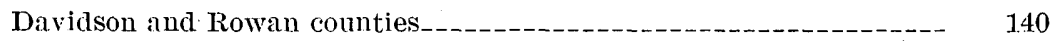

Gold-copper deposits _._-_._- 140

Gold Hill mines_____-_

Miscellaneous copper-gold mines

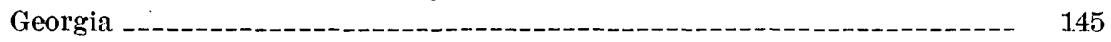

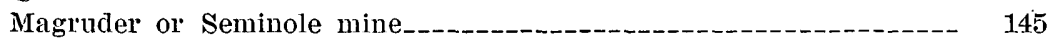

Chestatee property _-_.

Barton pyrite property

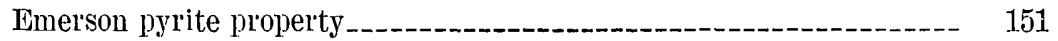

Tennessee _.

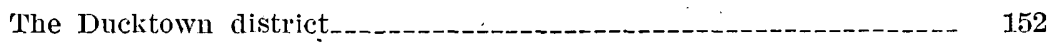

Veins -

Mines _-_-_-_-_._- 154

West vein -

Burra Burra mine

London mine -...- 154

East Teunessee mine

East vein -

Polk County and Mary mines____-__- 155

Callaway mine -

Isabella vein _._.

Ores _._. 157

Alabama _-_-_-_-_-_-_-_-_-_- 157

Geology _...

Mines_._. 158

Stone Hill mine_-_._- 158

Smith mine _._._-_._- 159

Alabama Pyrites Company's property-_-_- 160

Index 


\section{ILLUSTRATIONS.}

Page.

Prate I. Schist from ore bed of Ely mine, Ely, Vt___ 20

II. Polished specimen of Ely ore-_en 22

III. Fyrrhotite ore from Ely, Vt.; natural light_______._- 26

IV. Fyrrhotite ore from Ely, Vt.; same specimen as Plate III; reflected light

V. Diabase from copper deposit at Somerville, N. J_-_____-_- 50

Frgurs 1. Section showing vein structure in Waren mine, New Hampshire

2. Section showing occurrence of Elizabeth ore body, South Stratford, Vt.

4. Figure showing occurrence of native copper in contact rock, American mine, Somerville, N. J

5. Fissures cut by shaft of American copper mine, Somerville, N. J

7. Index map showing occurrence of copper ores in Virginia and other Southern Appalachian States

8. Brecciated epidotized basalt with ore and quartz; from copper mine on summit of Stonyman Mountain

9. Quartz lenticle of rein exposed in railway cut, Virgilina district, showing concentric slate shells

10. Diagram illustrating the formation of lenticular openings by movement of fissure walls

11. Diagram illustrating the structure of veins formed by the tearing apart of schist included between fault fissures or lying adjacent to fissures_.

12. Fitce of the 300 -foot level south in the Holloway mine, January, 1900

13. Ideal horizontal cross section of the Holloway vein, showing quartz spurs following the foliation of the country schist.-

14. Section of Durgy mine, Virgilina district, Virginia_-_-_-_---

15. Section of Anaconda mine, Virgilina district, Virginia_._._-_-

16. Section of Blue Wing mine, Virgilina district, Virginia_-----

17. Specimen of ore from Blue Wing mine, Virginia, showing banded structure

1.8. Blue Wing vein in face of 100 -foot level north

19. Blue Wing vein in roof over stope above the 100 -foot level, 350 feet south of shaft.

20. Blue Wing vein at the south face of the 100 -foot level

21. High Hill vein at shaft No. 4, north face of 60 -foot level

22. High Hill vein, north face, at bottom of shaft No. 4 
FraURe 23. High Hill vein, Virginia; exposure in south wall of shaft Page. No. 9

24. Asbestiform serpentine with native copper, from mine 7 miles southeast of Luray, Page County, Va_____-_._._.

25. Map showing location and course of gossan lead of Virginia

26. Ore from Chestnut Yard mine, Carroll County, Va

27. Pyrrhotite with included quartz fragments, Betty Baker mine, Carroll County, Va

28. Pyrrhotite interleaved with talc, Chestnut. Yard, Carroll County, Va

29. Longitudinal section along gossan lead, showing capping of iron ore

30. Workings of Union Copper Company mine at Gold Hill, N. C_

31. Section of Burra Burra vein, Ducktown, Tenn

32. Section through ore bodies of Mary mine, Ducktown, Tenn_-- 


\title{
COPPER DEPOSITS OF THE APPALACHIAN STATES.
}

\author{
By Walter Harvey Weed.
}

\section{INTRODUCTION.}

Copper ores occur and copper mining has at some time been carried on at many localities in the mountainous region of eastern North America, from . Canada to Alabama. The deposits are interesting scientifically and historically, and their availability as a source of copper is frequently discussed. At present there are few producing mines, but mining development is going on at several places and the openings afford sufficient data for an estimate of the productive capacity of particular properties.

Throughout the region certain broad features of rock structure and scenery persist, modified by differences in climate and vegetation. The rocks are predominantly metamorphic schists and gneisses, varying in texture, color, and amount of folding, but in general composed of similar minerals. They were classed by the earlier.geologists of the country as talcose sches and schists, chlorite schists, etc., but detailed mapping of many parts of the region by the United States Geological Survey and a study of thin sections of specimens of rocks obtained from all parts of the region by many students have shown that the schists are not as simple in character as had been supposed, but are really altered and disguised representatives of many forms of volcanic, igneous, and sedimentary rocks. The present "bedding" of the schists is now generally regarded as the result of regional metamorphism and is supposed to bear no fixed relation to the structure and composition of the original rocks. A homogeneous mass of granite may alter to a dozen types of rock wholly unlike in appearance.

The earlier theories concerning the origin of the ore bodies were based largely on the supposed similarity of the rocks and were consequently erroneous; and it is only since the searching methods of modern petrography and chemical analysis have been applied to the study of the rocks that one can discuss them with confidence. The question of genesis is of peculiar importance in this region, for it involves the value and extent of the deposits. Much money and 
time have been fruitlessly expended because the operator was not familiar with the origin and geologic relations of the rocks on the property he was exploiting.

This report is the result of an attempt to summarize existing information concerning all the known copper properties of the Appalachian region, including the Piedmont area east of the mountains. As it was not possible to visit every locality, and as many of the old workings are inaccessible, previous publications have been used to supplement personal observations. The field examinations were not exhaustive, and time for detailed mapping and prolonged study of thin sections of the rocks was lacking; hence the work is in the nature of a reconnaissance rather than of a detailed study.

The deposits are not great producers, but as they are used as the basis of mining ventures it is a matter of considerable interest to know whether there is any reasonable hope for the ultimate return of money invested from year to year in more or less unsatisfactory attempts to develop them. Moreover, the deposits are of various types, and their investigation is a matter of considerable scientific interest. An attempt has therefore been made to present a brief account of all the known deposits, even of those that are small and but little known, supplementing personal observations by citations from the publications of other observers.

A geographical grouping of the facts is given because it facilitates reference, especially by engineers interested in looking up the deposits in any particular State.

\section{CLASSIFICATION OF DEPOSITS.}

\section{TYPES DISCRIIIINATED.}

Throughout the Appalachian province the copper ores are confined to (1) crystalline schists; (2). altered basalts; (3) Triassic rocks close to trap intrusions; and (4) Devonian rocks, in which they generally occur in insignificant amount. The deposits present very diversified characters, no two being precisely alike, yet if their general characteristics be considered it will be noted that they all fall into six groups, or may be considered as variations of six general types, ${ }^{a}$ the word "type" being used to designate a characteristic example of a certain class, the members of which bear a broad family likeness to each other and possess certain essential characters, though perhaps unlike in many other ways.

The term is useful in bringing together deposits showing some similar features, and it facilitates an orderly discussion of phenomena.

In the detailed descriptions, however, no attempt has been made to group the deposits under types or in classes except in a broad way.

a Types of copper deposits in the southern United States; Am. Inst. Min. Eng., vol. 30,1901 , pp. $451-452$. 
It was deemed better to adopt a geographic rather than a systematic grouping, but tiresome detail is avoided by stating that the deposit described is of a certain type.

The six types are as follows:

1. Ducktown type. Pyrite. lenses and veins in crystalline schists. Occurs at Ely, vt.; Ore Ḱnob, N. C. ; southwest Virginia ; Ducktown, Tenn.; Milan, N. H. ; Davis, Mass.; and Stonehill, Ala.

2. Copper quartz-vein type. Quartz veins containing metallic sulphides:

(a) Virgilina variety; quartz veins with glance and bornite. Occurs at Copper Knob (Gap Creek), N. C.

(b) Gold Hill variety; silicified schists, containing chalcopyrite and pyrite, with ore shoots of quartz and chalcopyrite. Occurs in veins of North Carolina and Virginia gold belt.

(c) Seminole variety; zone of pyritized schists, carrying local shoots of ligh-grade ores.

3. Carolinian type. Bands of amphibolite traversing mica schists and carrying chalcopyrite and pyrite disseminated through the rock or gathered in bunches or, more commonly, deposited in the gray gneiss alongside. Occurs at Ilk Knob, Way-ye-hutta, and Peach Bottom, N. C., and at New Haven, Conn.

4. New Jersey type. Impregnated shale and sandstone adjacent to trap masses; in part in the trap. Occurs at Somerville, Arlington, and Griggstown, N. J., and at Leesburg and Orange, Va.

5. Pahaquarry type. Devonian sandstones impregnated with copper ores; and shales, etc., of Coal Measure regions with occasional ore; not rare, but insignificant in amount.

6. Blue Ridge (Catoctin) type. Bunches and joint fillings in the surficial portions of the basaltic rocks (Catoctin schist) of the Blue Ridge region.

\section{DUCKTOWN TYPE.}

The Ducktown type corresponds to a number of the "Kieslager" of German writers and is well known the world over. A definition of this type is as follows:

Ore beds lenticular in shape, repeated and connected by zones like fahlbands. The essential ore minerals are pyrite, chalcopyrite, and pyrrhotite. Sometimes one, sometimes the other of these ores prevail, but the first two appenr never to be absent; the last-named often fails. Galena, zinc blende, and other ores are on the whole subordinate.

Ore bodies of this class are more or less lenticular in shape and occur interbanded with the inclosing schists. The lenses may be thick or thin, long or short, alone or in many small thin lenses forming a bed. In general they apparently conform with the foliation or " bedding" of the inclosing schists, but detailed study of various deposits shows this to be less general than supposed.

The mineral composition of the Ducktown type is much the same over all the world. The ore may be pyrite or pyrrhotite or a mixture of both, with more or less chalcopyrite as an accessory, and, generally, zinc blende and galena in small amounts. Silver is common in the upper levels. The earthy or gangue minerals present greater variety. The ore in many deposits is impregnated country rock, 
slivers or fragments of which may occur even in the purer material. Garnet and actinolite or other forms of amphibole are common; biotite is found in many ores; quartz is universally present, but gen. erally in small amount; epidote, pyroxene, and zoisite are common.

Detailed studies of numerous deposits of this type disclose marked variations in character, indicating diverse origin and a varied history. The Norwegian, Spanish, Tasmanian, and Californian deposits, though superficially alike, possess very marked and different structural and mineralogic features. For this reason the more general designation of "pyritic beds" has not been used, and the name Ducktown type has been adopted as being noncommittal. It is certain, however, that the group includes deposits of diverse origin and nature: The Quebec deposits occur in altered volcanic rocks; the Vermont examples are genetically connected with granitic batholiths; the Virginia deposits are on fault planes; the Tennessee ore bodies are in altered sediments; and the Alabama ores are associated with basic rocks. It therefore appears certain that the ore bodies vary as widely in nature as do the inclosing "talcose and micaceous schists," which the microscope shows to be of diverse character and origin. Nevertheless, the term is convenient and will be used, as it conveys a definite and readily understood meaning as to the shape, mineral character, and structural relations of the deposits so designated.

\section{COPPER QUARTZ VEIN TYPE.}

The copper quartz veins present considerable differences in character and occurrence. On one hand they merge into the Ducktown type, on the other into pegmatites. In the region under discussion they occur only in schistose rocks. Their course is generally about parallel to the strike of the inclosing rocks, but as a rule they cross the layers in dip. At some localities the veins run at right angles, or nearly so, to the schists.

The quartz veins vary in nature: At Virgilina they consist of coarse and massive white quartz, with bornite and glance. As shown later, they occupy fault planes, are in part filled by friction breccia, and contain ores in well-defined bodies or shoots of quartz. A second variety, occuring throughout the Appalachian gold belt, is a schist vein carrying auriferous pyrite and bunches of chalcopyrite. This type (here designated the Gold Hill variety) is commonly found in areas that border the great granite masses of the region. The veins contain lenticular shoots of quartz carrying more or less copper and iron pyrite, and constitute the workable ore bodies, but grade into silicified and mineralized schist. A third variety (the Seminole) comprises veins composed of pegmatite material, allied to the Caro- 
linian tin veins, but containing copper. The rocks are sheared and metamorphosed and grade probably into veins of pure quartz.

\section{CAROLINIAN TYPE.}

The deposits designated the Carolinian type are a variation of the Ducktown type. They are pyritic and commonly occur in small lenses along a general line of fracturing. Their characteristic feature is their occurrence in or alongside of bands of hornblende gneiss or amphibolite. Many of them show gossan outcrops traceable for long distances, but the ore bodies are of slight extent. The essential minerals are pyrite, chalcopyrite, and pyrrhotite, with their decomposition products. These minerals occur intergrown with various silicates, but lie between and cement together fragments of the original hornblende, etc. Quartz is everywhere present, and at Cullowee corundum is found interlocked with chalcopyrite, indicating ore deposition later than the metamorphism of the country rock and probably connected with acidic granitic dikes. The type is common in the mountain region of North Carolina, and variants of it occur in Connecticut and Georgia.

\section{NEW JERSEY TYPE.}

The group of deposits which for convenience of reference has been called the New Jersey type has similar general characters but marked individual differences. Its members are abundant in the Watchung Mountain, New Jersey, and at various points in Connecticut and Virginia. The copper ores occur at or near the contact with intrusive or extrusive masses of trap rock. The ore minerals include native copper and its oxides and carbonates, rarely. bornite and glance in the oxidized zone, and glance and native copper in the deposit below the water level. The ores are found either in sandstones or in shales. Their genesis is discussed in detail in the description of the New Jersey deposits.

\section{PAHAQUARRY TYPE.}

The Pahaquarry (N. J.) type is an unusual form of impregnated sedimentary rock. At a number of places in the sedimentary areas of the Appalachian region certain beds locally contain nodules and irregular grains of copper ores, either glance or carbonates and oxides associated with coaly or animal matter. The ore is usually very small in amount and uncertain in occurrence. Many deposits carry silver. The source of the ore is supposed to be the decomposing sulphides of older rocks or deposits. The deposits occur either in gray rocks or in grayish to greenish spots in red rocks, but are found only in formations composed essentially of red rocks. 
At Pahaquarry Mountain, east of the Delaware Water Gap, a group of beds about 200 feet thick consists of alternating layers of gray glance, impregnated sandstone, and red shale. With this possible exception none of the deposits are workable.

\section{BLUE RIDGE OR CATOCTIN TYPE.}

\section{OCCURRENCE AND CHARACIER OF THE ORES.}

The Blue Ridge type, or, as it has elsewhere been called, the Catoctin type, comprises deposits of native copper and cuprite in green epidotic rocks that have been found at many places throughout the Blue Ridge region in the Appalachians and in the Piedmont Plateau. These deposits commonly occur in basalt and in the Catoctin schist. The barren rocks are dark gray or slate colored, but when ore bearing are yellowish-green, epidotic, and, in part, chloritic massive igneous rocks, altered by hydrometamorphism. 'The ore consists chiefly of cuprite and native copper, the latter often as nucleal masses surrounded by cuprite, together with small amounts of azurite and malachite and, very rarely, of copper sulphide. At the High Top mines east of Elkton, in Greene County, Va., and the Cove farm on Dickeys Ridge, south of Front Royal, bornite with scant chalcopyrite forms the most abundant ore. The ore occurs along crevices and joint planes, in small or curving crescent or S-shaped lenses of quartz, and to some extent as grains disseminated through the epidotized parts of the rock. Where the ore occurs the rocks are fractured and epidotized, or are irregularly checked by close and intersecting fissures, or, more commonly, are sheeted by parallel fissures. The quartz veinlets are rarely over 1 or 2 feet iong and 4 inches wide, and their. depth is usually proportional to their lateral extent. These individual quartz veinlets, many of which occur in one zone of sheeted rock, may be regarded as what were once commonly designated segregation veins. Much of the quartz is clear and limpid, and includes bright metallic copper. The ore is usually seen in the outcrop and masses of native copper are not uncommon. Generally the surface quartz is crackled, dull, and opaque, and the copper is dull.

At many of the localities visited the ores extend not more than 30 to 50 feet below the surface, usually less. Their occurrence in shear zones in the rock, which is generally massive or but slightly schistose; their confinement mainly to the secondary epidote and quartz veinlets; and their character indicate that deposits of this type were formed by the local concentration of material leached out of copper-rich portions of the altered igneous rock, in which the copper is believed to have been present as minute particles of pyrite or chalcopyrite. The deposit is therefore a product of superficial alteration, the shear zone affording a place for the gathering of the 
solutions and the deposition of material. These ores seldom occur in continuous masses, but can be traced for miles by the copper-bearing débris.

In general, no veins are seen, and the tendency of various observers to connect isolated outcrops by hypothetical veins has led to much misconception. As a rule, the ore is found in quantity only in the upper 10 to 30 feet of rock, occurring either in joints or impregnating the rock on either side. The flat joints, dipping only $5^{\circ}$ to $20^{\circ}$, are most commonly the joints that bear ore. Small and irregular patches of quartz and cuprite and native copper that have no recognizable connection with intersecting fissures also occur in the rock. The little gash veins of the quartz and the horizontal strain cracks of the serpentine and the ore both indicate the recent origin of the ores and their concentration from surface waters. In fact, the ores are confined to the epidotized rock and do not occur below the general zone of epidote alteration except where crushing and fissuring hâve carried this action exceptionally far down.

ORIGIN OF ORES OF 'THE BLUE RIDGE TYPE.

It is well known that many diabasic rocks contain copper. The rock of Orange (Watchung) Mountain, New Jersey, contains about one-fortieth of 1 per cent. Concentration of the basic constituents by the author showed that they contained a large amount of copper. The Blue Ridge rock (basalt) is itself undoubtedly the source of the copper. The Triassic traps do not show copper ores everywhere, though there are but few areas in which copper ores do not occur in or about some part of the mass. The localization of the ores is due in part, it is believed, to original differences in composition and in part to local conditions of fracturing and of water circulation.

The areas of basalt in the Blue Ridge are notable for the large amount of epidote which occurs in bands in the rock and is strewn in abundance over, the surface of the ground. In the massive form in which the rock occurs on the western slopes of the Blue Ridge in the vicinity of Front Royal, mining has shown that the epidotization is primarily a surface phenomenon, though it may extend downward along shear zones to a considerable depth. This epidotized rock, which by its color is readily distinguishable from the underlying blue, less altered rock, in many places contains nests and veinlets of calcite and of fibrous serpentine. There seems good reason to believe that some of the irregular, isolated bunches of ore and all of the little veinlets filled by serpentine were produced by tension resulting from the expansion of the rock, due to serpentinization, which has increased its volume, roughly speaking, about one-third. ${ }^{a}$ The epidotization appears to be a later phenomenon and to be due mainly 
to surface waters. It is closely connected with the appearance of native copper and copper oxide, more rarely of bornite and chalcopyrite, as films and minute nodules scattered through the rock. According to Rosenbusch ${ }^{a}$ epidote is a constant side product wherever calcareous iron and iron-magnesian silicates are chloritized, the lime being separated out and either deposited or removed as a carbonate. Thus, epidote accompanies the atmospheric decomposition of pyroxene, amphibole, mica, and garnet. It is most common in the altered igneous rocks, but is also a constant and characteristic constituent of certain stratified garnet rocks and certain amphibolites which are the equivalent of granular limestones. At the localities. where copper ores are found the deep workings show bunches and stringers of calcite and serpentine but no copper, though various transitions may be observed to the surface ores, with gradual repiacement of calcite by copper as a result of the action of infiltrating waters.

\section{MAINE.}

Early in the nineteenth century attempts were made to work the deposits on the northern borders of Maine and about 1880 the Blue Hill mine was opened, but as the deposit consists of lean slate ore, the ore bodies wedging out in depth, the work was unprofitable. According to the Tenth Census there were in Grafton County, Me., in 1880, three producing mines, whose aggregate product was 102,500 pounds of copper from 1,225 tons of ore. So far as known, none of the remaining deposits in Maine are either rich enough or large enough to warrant the expenditure of capital.

\section{NEW HAMPSHIRE.}

The copper ores found in New Hampshire occur in pyrite deposits inclosed in metamorphic schists or with other ores in quarts veins. Copper-bearing pyrite is worked at Milan, Coos County, and some copper ore is obtained in the magnetic separation of the zinc minerals of the Warren vein. Pyrite deposits occur in Grafton County at the Gardners Mountain or Lyman mines, at Haverhill, Lyme, and Oxford, and in southeast Hanover, northwest Enfield, and southwest Lebanon Townships; in Coos County, at Milan; and in Sullivan County, at Croydon, Unity .(4 miles from North Charleston), and in south Claremont Township. ${ }^{b}$

\section{GARDNERS MOUNTAIN MINES.}

The Gardners Mountain mines have been the basis of several mining ventures, and one property, the Paddock mine, produced 34,050 pounds of copper in 1880 .

a Iddings-Rosenbusch, Microscopical physiography of the rock-making minerals, 1893, pp. 294-295.

${ }^{b}$ Hitchcock, C. H., The geology of New Hampshire, vol. 3, pt. 5, pp. 50-52. 
According to Hitchcock, ${ }^{a}$ who gives a detailed description and map of the properties, the copper occurs as chalcopyrite and its oxidation products, together with zinc blende, some glance, and considerable pyrrhotite. The ore occurs in "veins" in four well-marked cupriferous belts, traceable for 12 miles. The rocks are greenstone schists (chlorite schists) with altered diabase and diorite, and argillaceous and calcareous schists. The veins are usually situated in broad belts of intermingled pyritiferous and siliceous layers separated by **** diorites. They are a foot or more thick and lie close together, forming a lode 6 to 10 feet broad. The ore is massive and is richest where it lies next to quartz. The vein matter consists of slate and quartz impregnated with chalcopyrite, pyrrhotite, and ankerite. The dip is $70^{\circ}$ to $75^{\circ}$ SE. Hitchcock discriminated three beltsthe westernmost, 178 feet wide; the middle 87 feet wide; and the easternmost, a zone of impregnated schist, 150 feet wide. From this it is evident that the ore occurs in thin layers, 2 to 6 inches thick, lying in a zone or fahlband of pyritized schist.

The Gardners Mountain properties were reopened in 1902 and glowing accounts of their richness were spread broadcast.

\section{WARREN MINE.}

The Warren mine is worthy of notice, as it has been worked for many years, at first as a copper property and later for its zinc ores. The vein occurs in a 50-foot layer or bed of tremolite inclosed in mica schist. The rock dips N. $50^{\circ}$ E. at an angle of $45^{\circ}$. Stringers

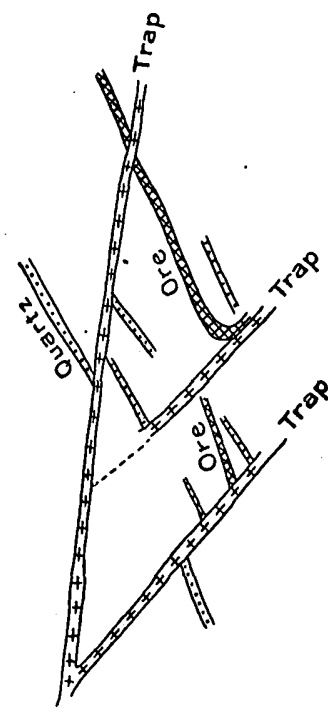

Figure 1.-Section show. ing vein structure in Warren mine, New Hampshire. After Hitchcock. of chalcopyrite and quartz occur along the hanging and foot walls of the bed, and bunches and disseminations of copper pyrite and zinc blende occur throughout the tremolite. The deposit is cut and faulted by trap dikes. Figure 1 shows the quartz vein (10 feet wide), the ore vein, and the trap dikes. The pay ore seems to form a pipe 15 feet wide and 20 feet broad.

The mine has been worked since 1840, the ores being concentrated and shipped for acid burning and the residue smelted at Bethlehem, Pa., for zinc. 
MILAN MINE.

The well-known pyrite mine at Milan, Coos County, N. H., which has been operated since 1881, though not now worked as a copper mine, has yielded considerable amounts of chalcopyrite. In early years 75 per cent of the ore was iron pyrite carrying 1.6 per cent of: copper, and 10 per cent was copper ore carrying a little blende and rarely some galena. ${ }^{b}$

The deposit consists of overlapping lenses 9 to 21 feet wide and a veraging 8 feet thick and 600 feet long, with a dip of $21^{\circ}$. The ore is incased in schist with chloritic slate hanging wall. The mine has long been an important producer of pyrite.

\section{LYMAN MINE.}

A property at Lyman was developed in 1902-3. The ore occurs in several bands of schist having an average width of 5 feet and containing iron pyrite with chalcopyrite and rich oxidized ores. No details are available of development work, as the property has not been visited.

\section{VERMONT. \\ FEATURES OF DEPOSITS.}

Copper mining was for many years an important industry in Vermont, and the Ely mine was at one time the largest copper producer of the country, but the mines are now either idle or have an insignificant output. The metal occurs in pyritic deposits in metamorphic schists, a type familiar the world over. The ore bodies consist of low-grade copper ore, showing considerable differences in the amount of insoluble matter present but being of fairly constant mineralogic character and of uniform copper content.

The deposits closely resemble those of Ducktown, Tenn., in mineral character and occurrence; they consist of a mass of pyrrhotite (magnetic pyrite), sparsely disseminated chalcopyrite and pyrite, and scattered and irregular grains and growths of quartz.

\section{GEOLOGIC RELATIONS.}

The deposits occur in the hilly region forming the eastern part of the Green Mountains, in Orange County, Vt. The three principal localities-Corinth, Copperfield, and South Strafford-are 7 to 10 miles west of Connecticut River, and lie on a north and south line, practically coincident with the schistosity of the neighboring rocks.

The ore bodies occur on the eastern flanks of a broad anticlinal uplift having a northerly pitch. This uplift is composed of schistose

a Wendt, A. F., Scl.ool of Mines Quart., vol. 7, p. 311. Martin, W., Pyrites: Mineral Resources U. S. for $1883-84$, U. S. Geol. Survey, 1885, p. 877. Davis, H. J., Pyrites : Mineral Resources U. S. for 1885, U. S. Geol. Survey, 1886, p. 501. 
rocks of undetermined but probable Silurian age, the nucleal core of the arch being formed of schists carrying much calcite, and hence called calcareous mica schists by the geologists of the Vermont and New Hampshire geological surveys. This "calcareous mica schist" grades upward into sericite schist with interfoliated impure limestones, and this series is overlain in turn, along the north and west sides of the arch, by an incomplete ring of impure semicrystalline limestone. To the east these limestones are wanting, but the overlying slates, partly roofing slates, occur on both the east and west sides of the uplift. Granite and pegmatite dikes, the latter carrying chalcopyrite, pyrite, and tourmaline as primary constituents, occur; and a few miles north of the copper range are the Barre granite quarries. Amphibolites also occur. The structural conditions indicate an underlying, deep-seated, but extensive batholitic mass of granitic material. According to the State geological reports, the rocks of the region may be divided into two formations, viz, Waits River ("Washington") limestone and Vershire ("Bradford") schist. The copper deposits occur only in the micaceous schists grouped under the latter name and corresponding roughly to the Savoy and Hawley schists of the Massachusetts area to the south. The rocks are in places mantled by glacial drift, and large areas are completely concealed by glacial moraines. Camptonite dikes occur at many places in Orange County, but none are known near the ore bodies. In the extension of the belt into Quebec similar dikes are later than the ore.

The ore deposition is, according to Smyth and Smith, ${ }^{a} \cdot$ dependent on structural features. The conclusions reached by these authors accord closely with those previously expressed by the writer, ${ }^{b}$ viz, that the rocks are metamorphosed sediments whose original bedding planes strike northwest and have a steep northeast dip. The present schistose structure is secondary and oblique to the bedding, the foliation being west of north, with a dip of $15^{\circ}$ to $35^{\circ} \mathrm{E}$. These relations, which are features of the broad anticlinal arch already mentioned, are further complicated by a crumpling or buckling of the main anticline into minor cross folds, which step down to the southeast, and which are of later date than the main period of folding. ${ }^{a}$ The Ely ore body is deposited in the crushed or open spaces along the crest of one of these cross folds.

The schistose rocks are prevailingly gray or slate-colored, and vary from coarse to fine in texture and foliation, the differences in color being due to variations in the proportions of biotite and quartz. At

\footnotetext{
a Smyth, H. L., and Smith, P. S., The copper deposits of Orange County, Vt.: Eng. and Min. Tour., vol. 77, 1904, p. 677.

${ }^{b}$ Bull. U. S. Geol. Survey No. 225, 1904, pp. 190-191.
} 
the Elizabeth mine the foliation is regular and persistent in direction. At Copperfield the general foliation is north and south and the dip $20^{\circ}$ to $30^{\circ} \mathrm{E}$., but the local foliations show close folding and puckering of the softer, more schistose beds, so that no single layer can be followed for any considerable distance.

The rocks, when crinkled, contain many intercalated masses of quartz, occupying the crests of the little anticlines and filling lenticular spaces along the flanks of the folds. These quartz masses represent in miniature the structure of the pyritic ore body of the Ely mine. (See Pl. I.)

The quartz may represent the residual silica freed in a sericitic alteration of the rocks or may be a pegmatitic exudation from a deeper-seated granitie magma. The study of thin sections of the ores and rocks suggests the origin last named and connects the mineralization of the region with that of the granite intrusions.

The granite masses of the county all resemble the Barre granite and are believed to be parts of a general mass. The Barre rock is a normal quartz-biotite granite, with accessory muscovite and apatite. It has a fairly uniform composition as a whole, but shows varied border facies, a feature noted in the Orange County bosses as well. The Barre intrusion has associated with it numerous dikes of pegmatitic granite, which, according to Finlay, grade into quartz veins and were accompanied by intrusions of camptonite in dikes. ${ }^{a}$

\section{ORE DEPOSITS.}

GENERAL CHARACTER.

The deposits of the Vermont copper belt occur as lenticular masses in foliated micaceous schists. They therefore simulate the type known as bedded deposits, being apparently entirely conformable to the schistosity of the inclosing rocks. The outcrops are generally concealed, however, except where the bed is exposed by mining operations. The ore forms lenses that differ considerably in horizontal extent and thickness, and these lenses overlap, the lower end of one lens overlying the upper end of another. This feature was observed at the Copperfield mine and at the Union mine in Corinth.

Some ore bodies show a clearly defined foot wall, but more commonly they grade into the adjacent rock. As a rule, the foot wall is more regular than the hanging wall, the latter showing frequent undulations.

The horizontal extent of the ore lenses differs considerably at the different mines and indeed in the different lenses of the same mine.

a Finlay, G. I., The granite area of Barre, vt.: Rept. State Geologist Vermont for $1901-2,1902$, p. 50 . 
a.t $x^{2}+2 x^{2}$ Ning

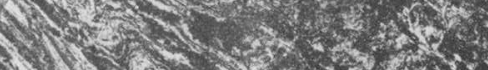
11 2?

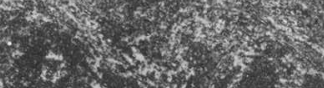

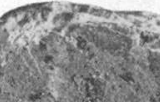

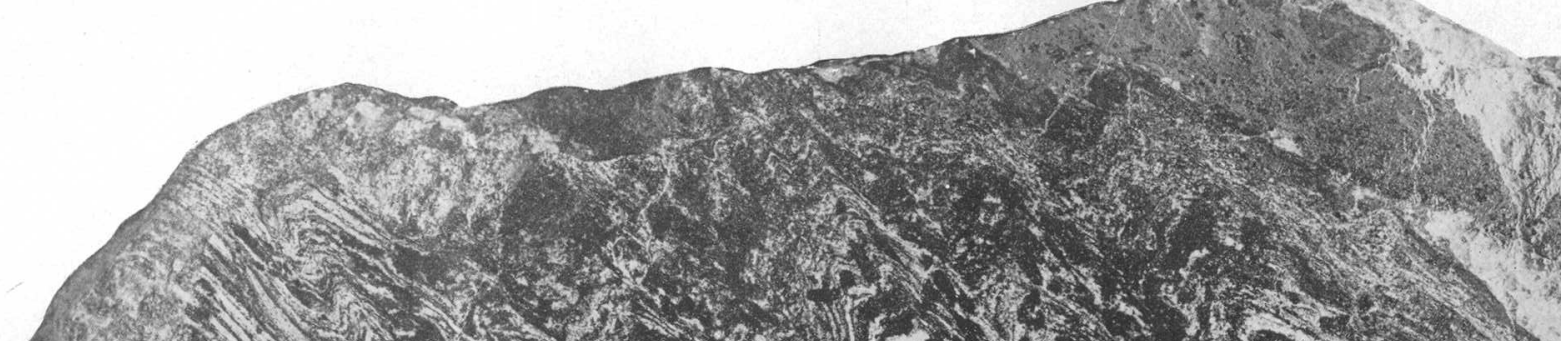

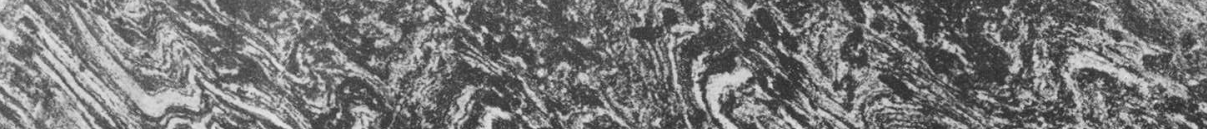

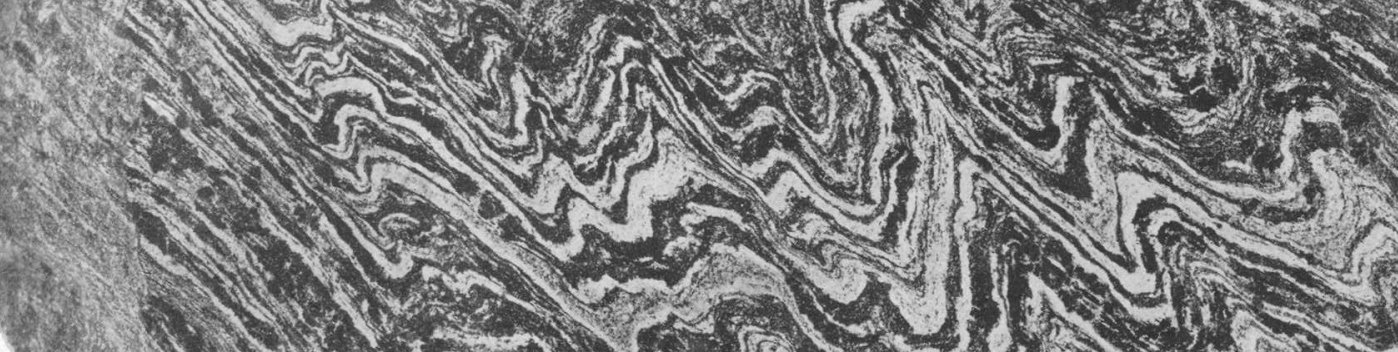
- 1 (n)

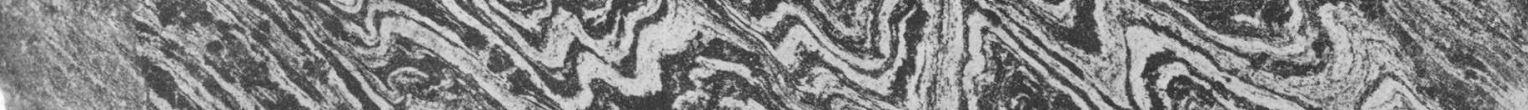

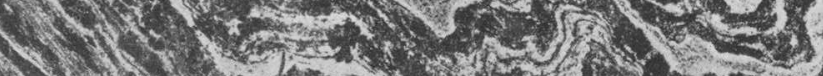
(167) 
In the Elizabeth mine the ore body ha's been extracted for 700 feet horizontally, and in the Ely mine a lens over 100 feet across has been mined. Along its strike the ore mass may either end in a blunt wedge, in some places showing a mere film continuing along the horizon, or the ore may fork into rapidly thinning wedges, or simply grade into country rock by an increasing amount of "slaty" material. The horizon of this Elizabeth ore body is traceable for nearly a mile, and another ore body (Reynolds) is found on its continuation $1 \frac{1}{2}$ miles northward.

The thickness differs according to locality. In the open-cut workings at the Elizabeth mine the ore is as much as 100 feet wide, and on the 225-foot level it measures 35 feet between walls; it has a maximum width of 12 feet at the Union and adjacent properties in Corinth Township, and of 20 feet at the Copperfield property.

The depth to which these deposits extend is not known. At the Ely mine the inclined shaft is 3,400 feet long. As already noted, the ore body consists of several lenses, one of which may pinch out; but in the Union and Ely mines the ore continues in overlapping lenses to the greatest depth attained.

The ore bodies are remarkably free from water. At a depth of 3,400 feet on the dip or 1,500 feet vertically the Ely ore body is very dry, the water of the mine being confined to a few hundred feet of upper workings. The ore and incasing rock are very solid in all the mines and practically no timbering is used.

THE ORES.

The ore consists of pyrrhotite (magnetic pyrite of iron, locally mundic) with scattered grains and irregular masses of chalcopyrite and small amounts of pyrite and zinc blende. The gangue contains quartz, actinolite, garnet, and other metamorphic minerals; in the main part of the ore body it consists of very massive pyrrhotite, with small amounts of quartz, etc.

The copper appears to be confined to the chalcopyrite, and though it is asserted by some observers that the pyrrhotite of the Elizabeth mine contains some copper, an examination of thin sections indicates that the copper is held in minute grains of chalcopyrite. This is shown in Plate II, in which the lightest areas are chalcopyrite, the polished specimen being photographed in reflected light.

The chemical composition of the ores is shown by the following average of chemical analyses of 11 samples of ore, about 8,500 pounds, taken at intervals along the drift in the Elizabeth mine. It should, however, be understood that this ore contains less silica than the ores of other localities. The analyses were furnished by John $\mathrm{N}$. Judson. 
Average composition of copper ore from the Elizabeth mine, South Strufford, Vt.

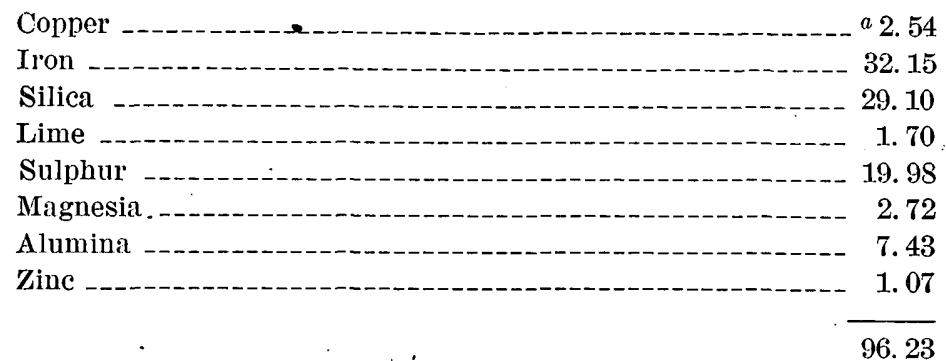

Gold trace to 0.2 ounce per ton.

Silver -trace to 0.2 ounce per ton.

The ore when cobbed to 5 per cent gave: Iron, 30 per cent; silica, 21.4 per cent. The Ely ore carries about 15 per cent more silica and the Corinth ores are of intermediate character. The relative amounts of silver and copper in the ore are about 0.1 ounce of silver to 1 per cent of copper. Gold is commonly present in mere traces, and though the values in some lots run up to $\$ 1.20$ per ton of ore they are spotty and seem to bear no relation to the percentage of copper. The blister copper produced at the Ely smelter in 1899 gave 13 ounces silver and $\$ 2$ in gold per ton.

Unlike the Elizabeth ores the product of the Copperfield mine shows a very uneven distribution of the silver values, as shown by the following assays of selected ores:

Assay of copper ores from the Copperfield or Ely mines, West Fairlee, Vt.

[In ounces per ton.]

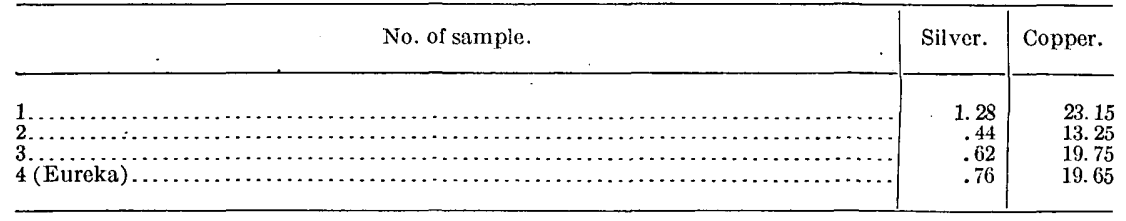

ORIGIN OF THE DEPOSITS.

The Ely ore body at Copperfield occurs along the line of one of the minor buckles or folds of the schists, where the beds have slipped and parted in folding, leaving a series of connected open spaces like the saddles along certain anticlinal folds. These spaces were found and followed by the mineralizing solutions. The ore was deposited partly in open spaces and partly by replacement, and it is later than the quartz lenses found in the rocks. In the Elizabeth ore body at South Strafford the ore occurs along the contact of a narrow dike of medium-grained biotite granite, cutting the normal schist. This granite is more or less replaced by ore, as is also the wall rock. 


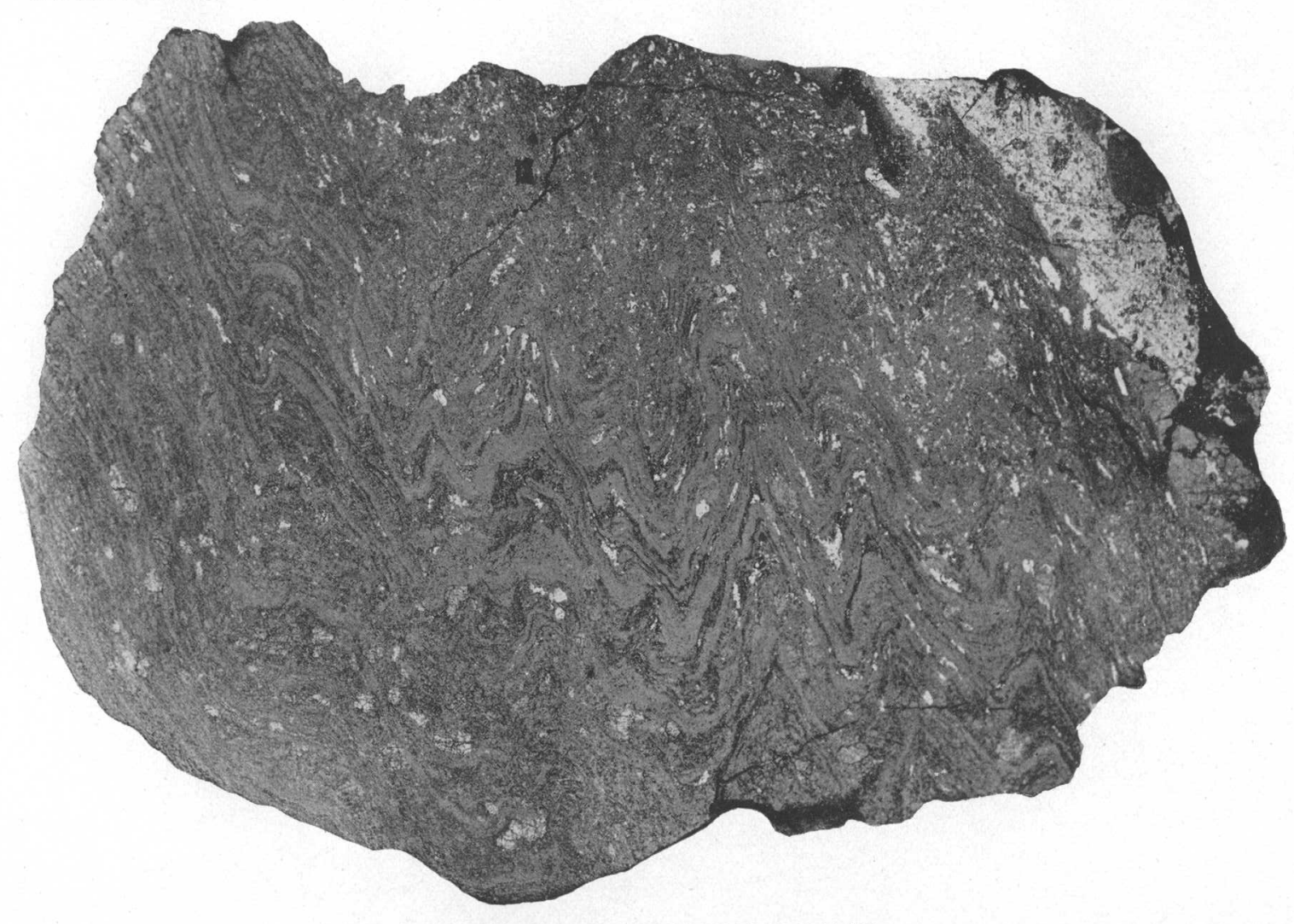

POLISHED SPECIMEN OF ORE FROM ELY, VT.

Reflected light. Light areas are chalcopyrite in schist gangue. 
The conclusions reached by Smyth and Smith ${ }^{a}$ as to the origin of the ores are as follows:

1. The two ore bodies have been formed mainly by replacement, at the Elizabeth along a fault fracture, and at the Ely along openings formed by folding.

2. The formation of these ore bodies was not connected with the principal folding and general metamorphism of the region, but was subsequent to it.

3. The regional metamorphism, to which period we refer the formation of the fractured quartz lenses and veins, does not seem to bave been attended in this district. with the formation of metallic sulphides in the open spaces along with the quartz.

4. The formation of the sulphide deposits probably followed closely on the intrusion and consolidation, at the levels now visible, of the biotite granite. There is reason to believe that the broad arch, on the eastern flank of which these sulphide deposits occur, is underlain by a great batholith of biotite granite. The local buckling at Copperfield and the faulting movement at Elizabeth may be explained by the shrinking and settling of such a batholith in cooling, which would necessarily bring down the overlying rocks unequally.

5 . On account of the association in both localities of the ore with the tourmaline, and on account of the vigor with which the country rock has been attacked and the completeness with which it has been replaced, we think it piobable that the mineralizing agents with the ores were derived from the deeper and unconsolidated portions of the granite magma referred to, and that the mineraljzing action was largely pneumatolytic ${ }^{b}$ in character.

The significance of the graphite as a precipitating agent was noted by Cazin. ${ }^{c}$

\section{COMPARISON WITH OTHER DEPOSITS.}

The similarity of these deposits to those of Ducktown, Tenn., has already been remarked. They are also very similar in form and mineral contents to the deposits in the Province of Quebec, Canada, which lie almost due north of the Vermont belt. Almost all previous writers have remarked on this fact and have attempted to correlate the deposits as a geologic unit, basing their conclusions on the similarity of the rocks and their occurrence along the strike of the schists. The danger of such hasty correlation is shown by the study of the Quebec deposits by Dresser. ${ }^{d}$ His work proves that the talcose, micaceous, or chloritic schists at Quebec are disguised volcanics of early geological age and variable composition, but are largely diabasic in character. The so-salled sandstones of the Ascot belt, in which the Capelton, Suffield, and Sherbrooke mines occur, are really a quartz porphyry; and the rocks of the westerly belt, embracing the copper mines of Acton, Upton, Roxton, Wickham, and St. Flavien,

"Op. cit., p. 678.

"Wheeler, H. A., School of Mines Quart., vol. 4, 1883, pp. 219-224. Posepny, F., Trans. Am. Inst. Min. Eng., vol, 23, p. 207, 1894. Wendt, A. F., School of Mines Quart., vol. 7, 1886, pp. 154-18s. Howe, H. M., Eng. and Min. Jour, vol. 12, 1.886, p. 327.

c Cazin, F. M. F., Trans. Am. Inst. Min. Eng., vol. 23, 1894, pp. 605-606.

d Dresser, J. A., Rept. Canadian Geol. Survey for 1903, 1904, pp. 146-147. 
are limestones with associated black graphitic shales intruded by igneous rocks, the copper ores being near and in places included in igneous masses.

\section{MINES.}

THE COPPERFIELD OR ELY MINE (VERSHIRE MINE).

HISTORY.

The Copperfield or Ely mine, near the village of West Fairlee, is the best known, as it is the deepest mine in the State. It was for many years known as the Vermont copper mine, and though other copper deposits have been worked the Ely has been the one great mine of the State.

The Ely mine was discovered in 1821, the burnt appearance of the outcrop leading to digging by the neighboring farmers. The discoverers organized the Farmers Company and opened up a body of good ore which they smelted in a rude furnace. This was continued with more or less success and interruption until in 1853 the Vermont Copper Mining . Company acquired the property, completed an adit (tunnel) and opened up an ore body 8 to 16 feet in thickness that a veraged over 9 per cent copper, as shipped, some shipments yielding as much as 17 per cent. The property was worked successfully, yielding large profits, from 1870 to 1880, but later, in consequence of bad management and litigation, it changed hands. It was then successfully and profitably worked for seven years, clearing over $\$ 4,000$ a month in 1888. The following year further litigation led to a change of ownership, and, with other causes, led to the closing down in 1892-93. It was acquired by Mr. George Westinghouse in 1899.

\section{PRODUCTION.}

No records are at hand to show the production prior to 1854 . The production since that year is, so far as known, given in the following table :

\section{Production of Copperfield mine.}

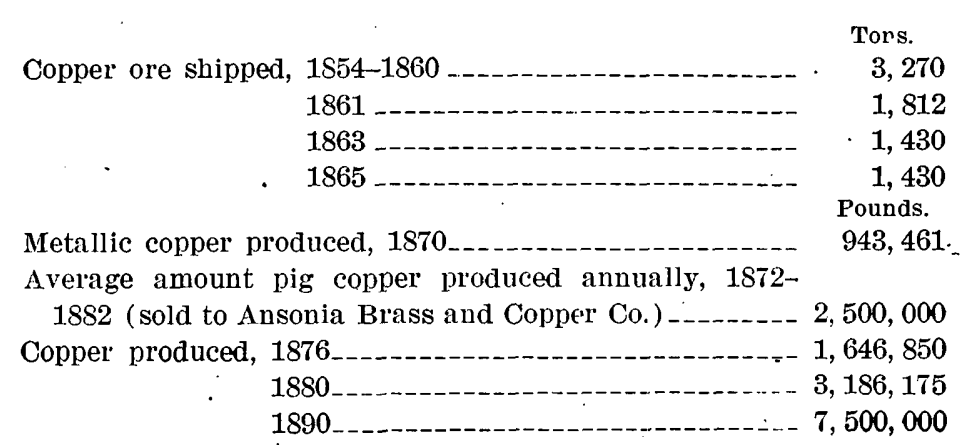


DEVELOPMENT.

The deposit was first developed by long crosscut adits (tunnels) - which, however, opened up comparatively small amounts of ore. An incline shaft was then begun and gradually extended downward, the ore being stoped out on each side as the worked progressed. When the ore pinched out downward, which has happened four or five times in the history of the mines, winzes were sunk in the foot wall and the upper end of the new lens was opened. This incline was 315 feet long in 1861: its depth was 1,800 feet in 1886 and 3,386 feet in 1903.

\section{REDUCTION WORKS.}

The property was equipped with smelting works early in its history, and was for many years regarded as a model in this respect. In 1885 there were 24 : brick furnaces of a type originating here and called the Vershire type. Rapid advances in metallurgical treatment soon made the plant antiquated, and it was remodeled by Cazin . in 1888-89 and a 100-ton concentrator built at an expense of $\$ 53,000$. The plant erected at that time is estimated to have cost $\$ 700,000$.

After the purchase of the property by the present owners various changes were made and a year's work done. The result was not satisfactory, for although equipped with modern water-jacket blast furnaces, reverberatories, and a Bessemer plant, the treatment of raw sulphides resulted in low-grade mattes (14 per cent) and the retreatment of material so increased the cost as to render the work unprofitable. The ore was found to be lower grade than had been expected and very siliceous.

\section{THE ORES}

The ore deposit is composed of two lenticular masses, averaging 100 feet in horizontal extent, 10 feet in thickness, and 100 to 300 feet along the dip. The ore bodies appear to be conformable to the foliation of the inclosing schists and therefore simulate bedded deposits. The strike is north and south and the dip is $24^{\circ} \mathrm{E}$.

The ore consists of magnetic pyrite and chalcopyrite, with some pyrite and sphalerite and intergrowths of quartz and actinolite; in the leaner ores biotite, calcite, garnet, and other characteristic metamorphic minerals occur. The chalcopyrite is partly of the same age as the pyrrhotite, but the larger masses of this mineral fill fractures in the pyrrhotite and represent the filling of later fractures.

A study of the thin sections of the ore made for me by $\mathrm{T}$. $\mathrm{L}$. Watson shows conclusively that the sulphides are of later formation than the silicates. The lean ore consists of quartz, with a mesh of hornblende needles, all more or less altered: Actinolite is present in small amount. Zoisite, so common in the analogous ores of Tennessee, is 
entirely absent. Brown biotite mica is very common in the ore, forming tufts and groups of elongated shreds. In some samples much of the biotite is altered to brownish red rutile. An examination of the ore on the dump shows that although in some specimens hornblende and biotite occur together, yet there is a general tendency toward segregation of one or the other.

The ores, as mined, carry an average of 3 per cent copper. They contain small amounts of gold and silver and a little zinc, and are free from arsenic and antimony. The Bessemer copper contains about 13 ounces of silver and $\$ 2$ in gold per ton.

The average composition of the ore (from information furnished by the owners) is:

Average composition of ore of Copperficld mine,

$\begin{array}{lr}\text { Copper } & \\ \text { Iron_- } 31 \\ \text { Sulphur } \\ \text { Insoluble }\end{array}$

An interesting feature of the ore and one that has an important bearing on its treatment, is the brittleness of the quartz. So marked is this that when the ore is subjected to coarse crushing it yields about 40 per cent of fines which carry more silica than the lump ore. The following analyses, kindly furnished by the owner, show the results of actual tests on large samples of No. 1 ore: $\quad$.

Analyses of coarse and fine ore.

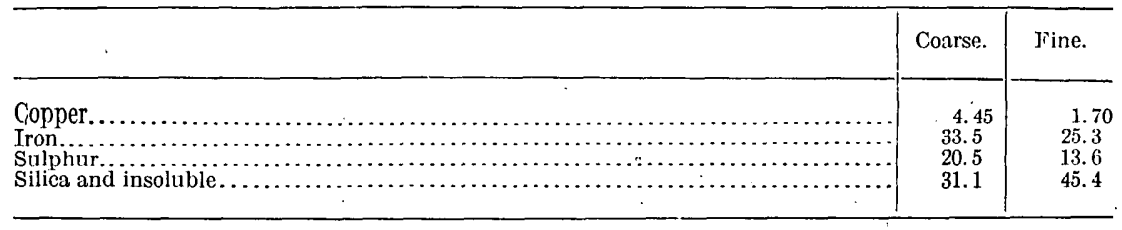

PETROGRAPHY OF THE ORES AND ROCKS.

MINERALS OF THE ROCKS.

Thin sections of the rocks and ores of the Ely mine at Copperfield have been carefully studied under the microscope by Prof. T. L. Watson, and as the ores and rocks are fairly typical for the entire district the results of his study are given here in detail.

The thin sections show the rocks to be crystalline schists, usually of a pronounced and thinly foliated type. Several exceptions, however, may be noted, in which the thinly foliated structure is not apparent in the thin sections and the rock would probably be more properly classed as a mica gneiss. Except for the coarse foliation the rocks are the same as the schists in all essentials. 


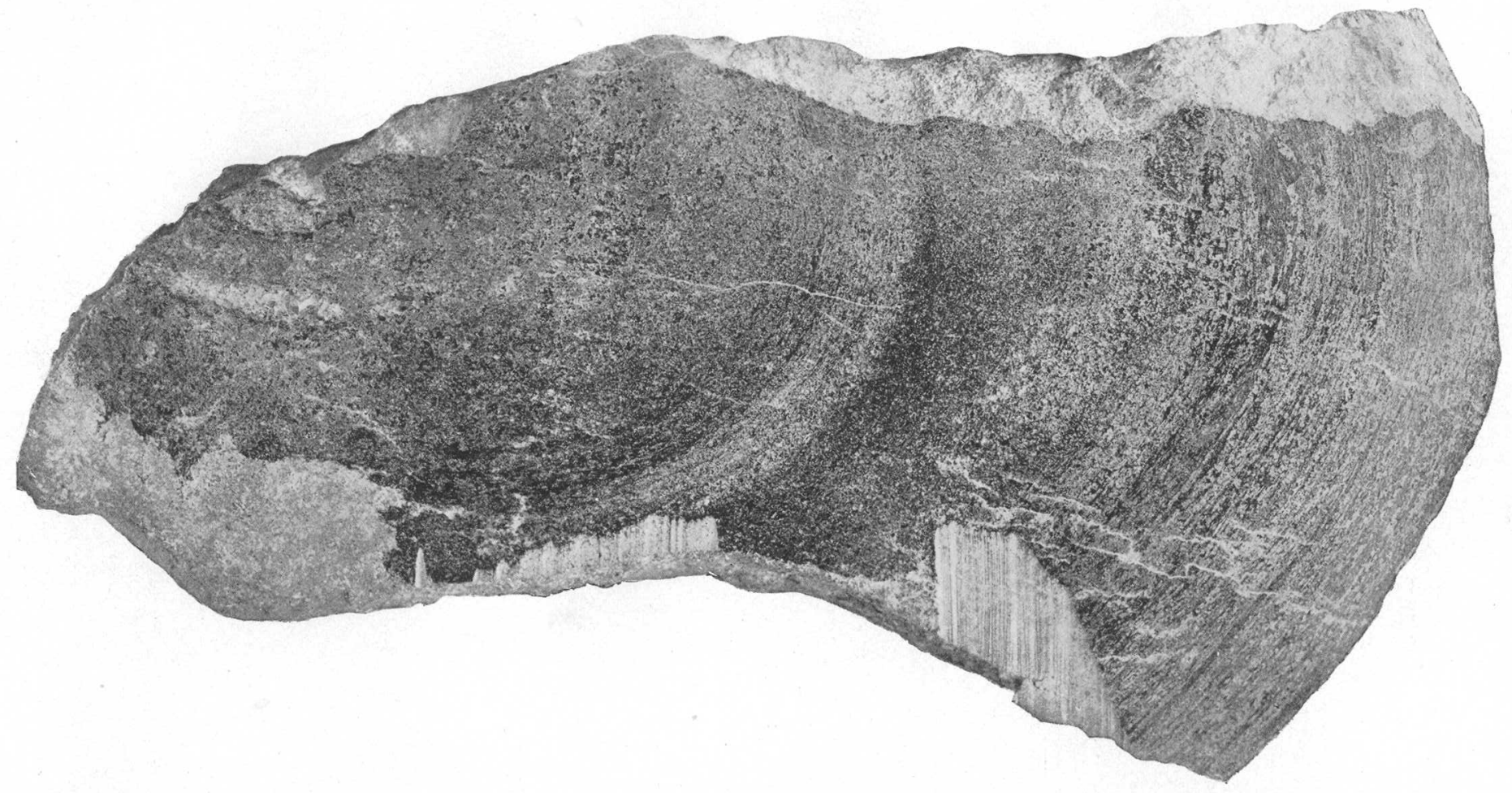

PYRRHOTITE ORE FROM ELY, VT

Natural light. 


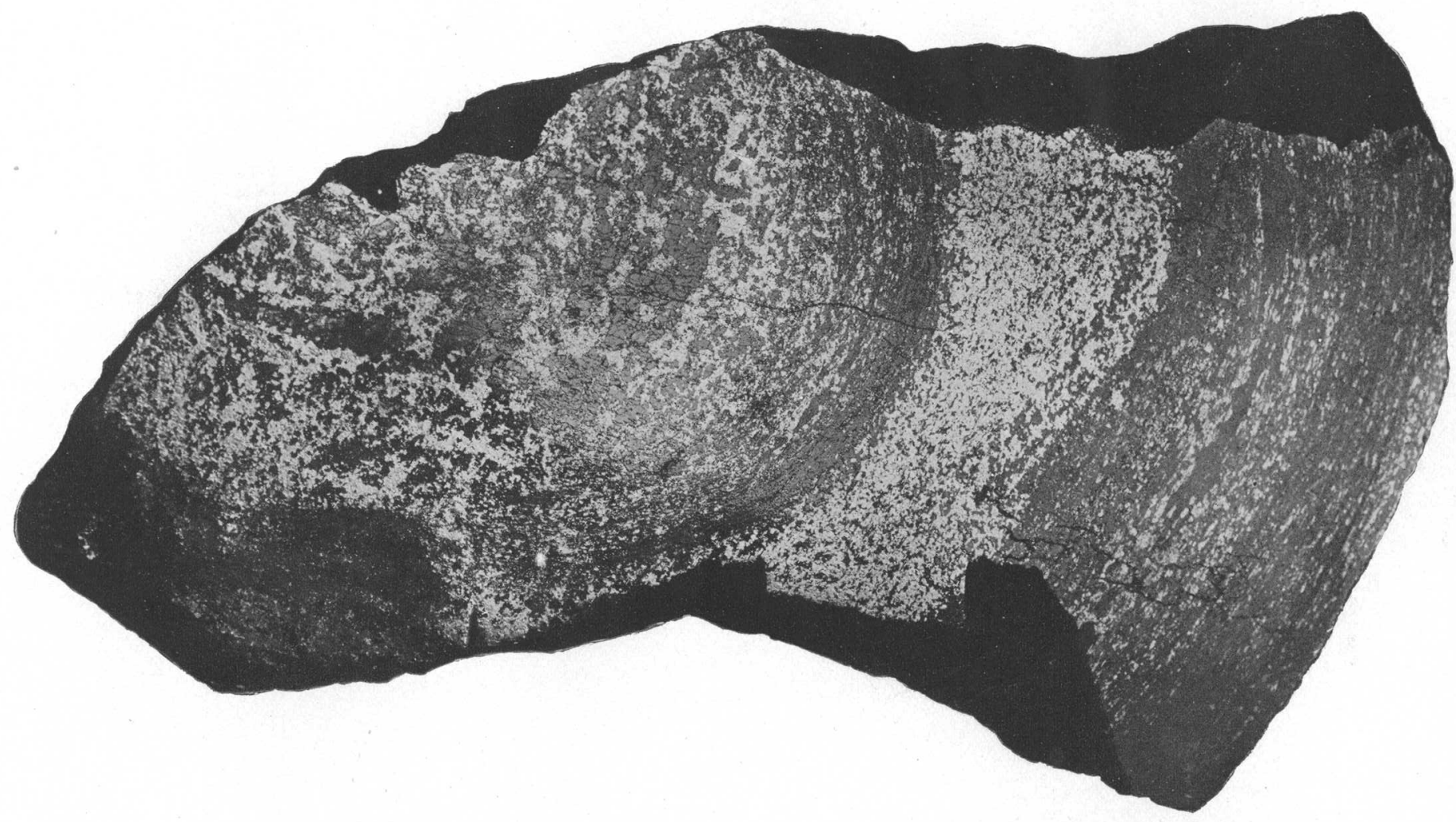

PYRRHOTITE ORE FROM ELY, VT., SHOWING DISTRIBUTION OF CHALCOPYRITE (WHITE AREAS) IN PYRRHOTITE. 
The thin sections show that the dominant type is a biotite gneiss containing some muscovite and feldspar; the thinly foliated rocks from the mine are alterations of this gneiss, impregnated with pyrrhotite and chalcopyrite.

In studying the thin sections of the rocks two types are distinguished. In one type the principal ferromagnesian mineral is biotite; in the other it is hornblende.

The type most abundant is a biotite rock, noted as gneiss or as schist-gneiss if thick banded and schist if thin banded. The principal minerals of this rock are quartz and biotite, some muscovite, and a little feldspar. Much calcite appears in several of the thin.sections, and garnet is present in all, but is more abundant in some than in others. All the rocks are mineralized to some degree with the sulphides-pyrrhotite and chalcopyrite.

The second type of rock, represented by only one section (No. 106), is a hornblende schist. The principal minerals are large, stout blades of bluish-green hornblende, quartz, some feldspar, and a little calcite. Hornblende is very abundant, with prismatic cleavage developed in one direction parallel to the longer axis of the shreds; it is more or less altered and frayed out around the edges, and is filled with grains of other minerals, which impart to it a mottled appearance. Much calcite is associated with the hornblende as a secondary mineral, replacing in part the hornblende substance. A noticeable feature is the absence of biotite. The section shows impregnations of the sulphide ores-pyrrhotite and chalcopyrite.

Only one other section of the rocks showed the presence of hornblende (No. 102). In this section both biotite and hornblende appear, but not in very intimate association. The biotite alternates as thin bands with the light-colored minerals distributed over one part of the section and hornblende similarly distributed over the other part. Very few scattered shreds of the biotite occur with the hornblende. 'The hornblende substance is much leached, and in many cases it is nearly or quite colorless, except along the lines of cleavage and fracture, where yellowish-brown staining from the liberated iron oxide appears. Both garnet and calcite appear, and the section is strongly mineralized with the sulphides-pyrrhotite and chalcopyrite.

A very marked feature of the sections as a whole is the very conspicuous effects from squeezing and mashing shown in the mineral constituents. These are: Conspicuous foliation resulting in the parallel arrangement of the individual minerals along a definite direction; abundant irregular fractures crossing the quartz and feldspar individuals and frequent similar rupturing of the biotite and hornblende; peripheral granulation of many of the larger quartz anhedra; frequent bent and curved shapes of the biotite shreds; and 
prevailing undulous extinction of the individual minerals, especially quartz and feldspar. In several sections micrographic intergrowths of quartz and feldspar are observed, and the usual sprinkling of the common accessories in such rocks is noted in all the sections.

There appears no real evidence for regarding any of the rocks other than the equivalents of profoundly altered and metamorphosed sediments.

THE MINERALS OF THE GANGUE.

The thin sections show the common minerals in association with the ores to be quartz, biotite, tourmaline, hornblende, feldspar, and a little calcite. The relation of the ores to each other suggests that their formation does not belong entirely to a single period, but that at least two periods, separated by an indefinite time.interval, were involved.

Quartz.-Quartz is one of the most abundant if not the most abundant minerals in both the veins and the country rock. It occurs in large and small anhedra, always exhibiting fracture lines and wavy extinction and generally containing inclusions whose exact identity is not determinable in every specimen. It further occurs as irregular small grains of roughly rounded outlines through the ore substance. In every case the quartz seems older than the ores, as shown. by the latter penetrating and filling the cracks in the quartz, and by the distinct replacement of more or less of the quartz substance.

Biotite.-Like quartz, biotite forms one of the most abundant silicate minerals in the veins and the country rock. It is deep brown in color, possesses strong absorption, and occurs as single shreds and aggregates, though most abundant as aggregates. The shreds are frequently bent and curved, and in some specimens they are broken a.cross. The sulphide ores have penetrated along the cleavage and fracture lines, and in many places completely surround and inclose the shreds, indicating that the biotite is the older.

Tourmaline.-Tourmaline, which is fairly abundant in nearly all of the thin sections, is the most interesting of the gangue minerals. Its presence indicates the action of fumarolic vapors. So far as the writer is aware, its occurrence with copper ores is very unusual in America, though it has been occasionally noted in foreign localities.

Its microscopic characters are definite in the sections studied, and there can be no question as to its identity. It is light brown in color, possesses strong absorption, and is usually very much fractured. Both basal and prismatic sections occur, the latter probably being the most common. It is, in every case, older than the ores. The ore fills the irregular fractures of the tourmaline, and in many. instances the tourmaline is inclosed by the ore. 
Amphibole.-Amphibole has been observed in most of the thin sections of the vein material. It can without doubt be referred to the variety hornblende: It forms single grains and shreds, part of which exhibits the two prismatic cleavages strongly and equally developed; the other part develops only one cleavage parallel to the longer axis of the individual. In many specimens the hornblende has suffered much leaching, and it is accordingly rendered nearly or quite colorless. The yellow-brown staining of the liberated iron oxide is very noticeable along the cleavage directions in much of the leached mineral. The sulphides have been deposited along the cleavage directions and in the broken parts of the hornblende, replacing the latter mineral in part.

Feldspar.-Feldspar is not uncommon in some of the sections, though it is less abundant than either of the minerals described above. Both potash and plagioclase species are recognized. It shows more or less alteration, and in common with the other minerals it has suffered from pressure effects. It is older than the ores, the latter bearing the same relation to the feldspar as to the minerals already described.

Garnet.-Garnet has been observed in nearly all the sections of the country rock, but does not appear in any of the sections cut from the more completely mineralized rocks. It occurs in large coarsely crystalline grains without crystal boundaries and is much fractured from dynamometamorphism. It has a slightly reddish cast and its substance is remarkably fresh. The sulphide ores have usually filled in along the fracture lines.

Calcite.-Calcite is by no means an abundant mineral in the sections, but it is fairly well scattered through a number of them. Like garnet, it has its greatest abundance in the slides from the leaner rocks. Where it is possible to make out the relation of the ore to this mineral, the evidence seems pretty conclusive that the ore entered after the formation of the calcite. It is, of course, not impossible that the calcite has had several periods of formation, though evidence is lacking to confirm this view.

MINERALS OF THE ORES.

The ore is made up almost entirely of pyrrhotite and chalcopyrite, very intimately intermingled. The ore, pyrrhotite and chalcopyrite, is massive granular, with no evidence of banding. In those sections showing the best development of the ores, irregular fracture lines are common alike to the pyrrhotite and chalcopyrite, evidencing movement in the rocks since the formation of the ores. In the larger masses of ore irregular, more or less rounded grains of quartz, biotite, and in some places tourmaline, may be detected through the ore substance. 
Pyrrhotite.-Pyrrhotite is variable in quantity, though present in all the thin sections and predominating in some. There seems good evidence for regarding it in general as the older of the two sulphides, since the chalcopyrite has been observed in several of the sections to penetrate and fill some of the fractures in the pyrrhotite.

Chalcopyrite.-Chalcopyrite predominates in some sections and is in smaller amount than pyrrhotite in others. Both the chalcopyrite and pyrrhotite occur in granular and massive-granular form, and in no case has either been noted with crystal outline. The chalcopyrite may occur alone as disseminated grains through the silicate minerals, but it is very generally closely and intimately associated with the pyrrhotite. So intimate is the association between the two ores that it is in many specimens very difficult, if not impossible, to make out the exact relations between them, particularly as to which is the older. Indeed, the explanation most reasonable to the writer is to regard the relations as due to several periods of filling.

FORMATION OF THE ORES.

- Sufficient detail has been cited above to show that after the formation of the silicate minerals (biotite, tourmaline, hornblende, garnet, and feldspar) the rocks were subjected to considerable movement and crushing, perhaps also to folding and faulting. Later, the solutions of the metallic sulphides entered and were precipitated along and in the fractures, replacing more or less the substance of the silicate minerals. This was succeeded by another period of deformation, which resulted in further crushing and fracturing of the silicates and the precipitated metallic sulphides, followed probably by further mineralization by the metallic sulphides. Much replacement of the silicate minerals by the sulphides has been involved in the formation of the ores of the district.

\section{ELIZABE'TH MINE.}

\section{EQUIPMENT AND WORKINGS.}

The Elizabeth mine, at Copperas Hill, near the town of South Strafford, and about 6 miles due south of Copperfield (Ely mine), is the oldest copper mine in the State. It was opened in 1793, the magnetic pyrite being used for the manufacture of copperas (sulphate of iron). The manufacture of copperas was continued for many years, until the discovery of increasing amounts of copper led to the working of the property for that metal and the building of a smelting plant. The production was 2,804 tons in 1883 , and 3,299 tons from 1881 to 1884 .

The mine is equipped with a power plant, a 4-drill air compressor, ore bins, crusher, picking belt, and a small smelter plant. 
The early development consisted of open-cut work with a 60 -foot drift. In 1886 a vertical shaft 160 feet deep was sunk in the hanging wall, cutting the ore at a depth of 100 feet and continuing in it to the bottom. From this shaft, at a point 50 feet below the surface, two drifts were driven, one 200 feet southward, connecting with the open-cut work, and another 300 feet northward. At the 110-foot level two other drifts were driven, one 100 feet southward and the other 225 feet northward, and a drift at the 160-foot level afforded the main stoping ground. A winze 60 feet deep connects this drift with the 225-foot adit workings. In 1898 a crosscut tunnel 1,340 feet long was finished, opening up the ore body 225 feet below the outcrop. There is 578 feet of drifting on this level.

THE ORES.

Thè ore body (fig. 2) is interlaminated with micaceous schists, forming $a$ lens whose axis pitches gently to the north, making a long

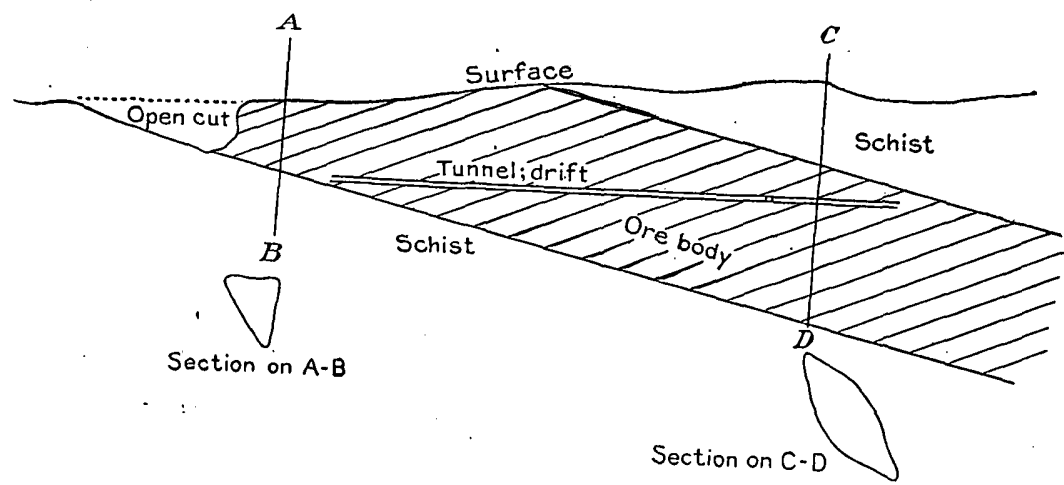

Figure 2.-Section showing occurrence of the Elizabeth ore body, South Strafford, vt.

outcrop and indicating a large lens. The foot-wall rock is harder and more quartzose than the hanging-wall material. The foot wall is smooth and regular and in the open-cut workings is seen to form a well-defined plane with a dip of $70^{\circ} \mathrm{E}$. The ore body has a northeast-southwest course. The ore lens is 60 feet in maximum thickness and not more than 150 feet long and is said to pinch out along the outcrop at a point about 700 feet south of the shaft. Its width varies from 25 to 100 feet along this open cut. On the 225-foot level the ore measures 35 feet between walls, but only 24 feet of this has been extracted. As seen in the open cut, the ore body is a compound one, with a slab of schist 2 to 5 feet thick separating the main mass from the hanging-wall layer.

The ore is similar in mineralogic character to that of the other deposits of the belt. The ore varies from 1.7 per cent to 3.32 per cent; its average composition has already been given (p. 22). The best ore occurs in the central 6 to 8 feet, and becomes lower grade as 
the walls are approached, the ore passing gradually into the country rock. This feature is particularly well shown in the foot wall at the north end of the 225-foot level. Samples from each section of the vein were assayed and yielded the percentages of copper shown in the following table. The figures were furnished by Mr. John N. Judson:

Copper in ore from Elizabeth mine.

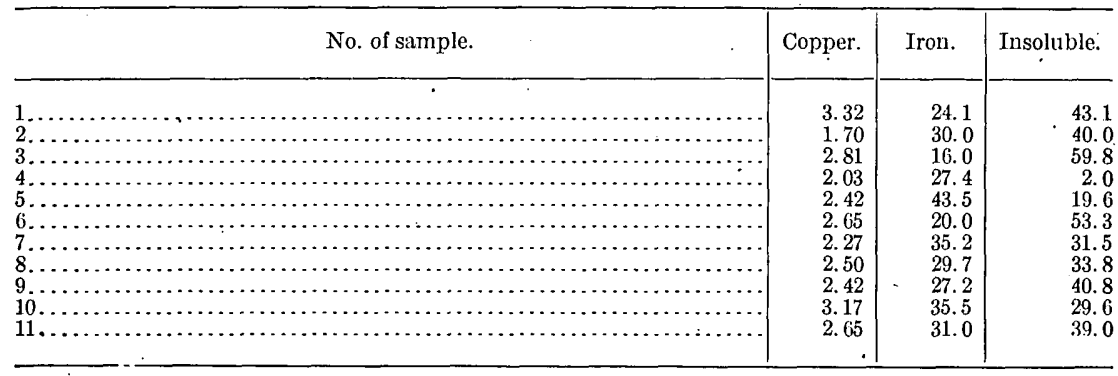

Each sample represents a width of 10 feet. As already noted (p. 21) this ore is low in silica compared with other properties in the State. The total amount developed is estimated by private parties at 275,000 tons of 3 per cent material. In working this mine in 1899 and 1900 the ore was broken and sorted into two grades, the richer portion (No. 1) carrying about 4 per cent copper and amounting to 30 to 35 per cent of the total tonnage, was hauled to the railroad and shipped. The second-class ore (No. 2), averaging but 2 per cent copper, was placed on roast heaps for local treatment. Only 5 per cent of waste was produced in sorting the ore.

\section{. CORINTH MINES.}

The mines of Corinth Township are about 11 miles north of Copperfield and 7 miles west of the Boston \& Maine Railroad. The cre bodies lie in gneissoid rocks that are somewhat harder than the micaceous schists to the south. There are two adjoining mines, the Union and the Eureka.

\section{UNION MINE.}

The Union mine was first opened in 1866. The production from that year up to 1881, inclusive, amounted to 31,504 tons of ore, carrying 8.5 per cent to 10 per cent copper. In 1879 and 1880 a total of $5,712,604$ pounds of fines, carrying 2.7 per cent to 4.5 per cent copper, was sent to the Copperfield smelter.

The property is developed by an inclined shaft about 900 feet long, reaching to 766 feet below the adit level. To a depth of 300 feet four overlapping lenses of ore were worked. The shaft leaves the ore at a depth of 500 feet on the incline below the adit level 
and continues downward in the hanging-wall schists. The lower ore bodies are developed by winzes sunk in the foot wall. Assay of a sample of selected ore from the dump showed 8.15 per cent copper, 25 per cent silica, traces of gold, and 0.3 ounce silver per ton. The vein has a north-south course, dips $30^{\circ} \mathrm{E}$., and has an average thickness of 8 feet.

\section{EUREKA MINE.}

The Eureka mine lies south of the Union. It has been opened by an inclined shaft said to be 500 feet deep and two adit levels, the uppermost cutting the vein at a depth of 200 feet below the outcrop. The vein is said to average 8 feet in thickness and about 100 feet in horizontal extent. Selected samples of the rich ore contained 19.65 per cent copper, 19.52 per cent silica, and 0.76 ounce silver per ton of ore.

\section{MASSACHUSETTS.}

Copper minerals occur at a number of localities in Massachusetts, but the deposits of true copper ore are all small and attempts to work them have so far been unsuccessful. The Triassic sandstones carry native copper at many localities, but not in sufficient abundance to make the deposits workable.

DAVIS MINE.

The well-known Davis pyrite mine at Davis, in Franklin County, 4 miles from Charlemont, is a lens of pyrite interbedded with schist. It has been worked for many years, yielding a firm crystalline pyrite, with a little chalcopyrite which was separated by hand picking mixed with the roasted cinder from the acid works, and smelted, as early as $1885 .^{a}$

The mine is now 1,000 feet deep and produces about 400 tons of mineral a day. Contrary to the usual experience in pyritic lenses in metamorphic schists, the copper contact is as great at this depth as at the surface. The ore, after roasting for the extraction of sulphur. is sent to Garmar, N. J., and its copper content extracted by leaching and precipitation on scrap iron.

The mine is in Rowe Township, only a few miles south of the Vermont line, in the southern continuation of the Green Mountain region. The district has been studied and mapped by Prof. B. K. Emerson," from whose work on Old Hampshire County, Mass.; the following notes are taken.

The Davis pyrite deposit occurs in the Hawley schist, a formation of Ordovician age, composed mainly of sericite schist with intrusive bands of amphibolite. The prevalent rock is a dark-green soft. chlo-

a Mineral Resóurces U. S. for $1883-84$, U. S. Geol. Survey, 1885 , p. 8'6 ; idem for 1885 , 1886, p. 503.

'Mon. U. S. Geol. Survey, vol. 29, 1898, pp. 270, 271. 
ritic schist, crowded with porphyritic grains of brown ankerite a fraction of an inch across. When the rock carries tufts of hornblende it is called fasciculite.

The belt of Hawley schist carries lenticular beds and impregnations of pyrite in Hawley Township and northward. Many beds have been unsuccessfully opened, the Davis mine, near the east line of Rowe Township, being thus far the only continuous producer.

The Davis pyrite deposit is a great lens, 6 feet to 24 feet thick, that lies intercalated between sericite schist on the west and chlorite schist on the east. The deposit has a strike of N. $30^{\circ} \mathrm{E}$. and a dip of $70^{\circ} \mathrm{E}$., both conforming closely to that of the inclosing rocks. The deposit consists of coarsely granular pyrite, with some admixed chalcopyrite, blende, garnet, and gahnite, the two last named being rare. In 1892 the bed had been opened for 700 feet along the strike and to 425 feet in depth. The total output to January 1, 1892, was 334,552 tons.

\section{OTHER MASSACHUSETTS DEPOSITS.}

At most of the other properties the pyrite is not pure, but requires concentration. All the pyrite beds of the region contain small amounts of chalcopyrite, and near Plainfield small amounts of ore have been mined. Bornite occurs in a sericite schist much impregnated with granitic material. ${ }^{a}$

About 2 miles west of the Davis mine a property opened in 1900 and intermittently worked since that date shows, according to information furnished to Stevens Handbook by Prof. W. O. Crosby, an approximately vertical vein, conforming in strike and dip to the inclosing Savoy schist.

It is apparently a fahlband, lacking well-defined walls, the ore being scattered through 15 to 20 feet of schist. There is a seam of well-mineralized quartz, 6 to 12 inches wide, lying along the south wall, and on the north wall there is a streak of chalcopyrite 1 to 2 feet wide. The vein is exposed by stripping and crosscutting for a distance of 700 feet. $^{b}$

At Windsor Bush, 11 miles from Charlemont and 6 miles west of Plainfield, in Hampshire County, a property was opened in 1903, supposedly on the same belt as the Davis mine. In that year, according to information received from Mr. Charles Hallock, the mine was equipped with two steam hoists and had a shaft 100 feet deep, on which the first 60 feet was vertical and the remainder inclined. The vein was said to be 17 feet wide. The mine was supposed to be located on the same belt of hornblende gneiss as the Orange County, Vt., mines and as the copper mine at Simsbury, Conn., but this is not confirmed by Emerson's map. ${ }^{c}$

a Emerson, B. K., op. cit., p. 171.

${ }^{b}$ Stevens, H. J., Copper handbook, vol. 6, 1906, p. $\gamma \hat{s}$.

- Op. cit., Pl. XXXV. 


\section{CONNECTICUT.}

\section{OCCURRENCE AND CHARACTER OF ORES.}

Copper occurs at a number of localities in Connecticut, accompanying the trap ranges which extend south from Granby through Avon, Southington, Cheshire, and Hamden. The ores are observed only where the trap cuts the Triassic rocks, the copper being found either in the trap or in the adjoining indurated sandstone, most abundantly in the latter.

Pyrite deposits of sufficient purity to work have not been found in Connecticut. Pyrrhotite occurs at Prospect Hill, in western Litchfield, near Bradleyville, but the ore is not clean.

The association of the copper ores with the trap rocks was noted by Percival in 1842 . He says: ${ }^{a}$

All the metallic veins *** are found either in the trap or in the shale or sandstone immediately adjoining. When they occur in the trap they are found in its lateral portions, particularly in the amygdaloid. The metallic veins in the trap have usually a matrix of sulphate of barytes, quartz, and calcareous spar, and occasionally contain seams or nodules of indurated bitumen. * * * It [the copper] is also more particularly connected with the range of West Rock and Mount Carmel, the posterior trap range north of the latter, and the fourth eastern main trap range from the Hanging Hills northward.

\section{Percival adds: ${ }^{b}$}

${ }^{\circ}$ Copper ores also occur in the chloritic schists and the hornblendic schists extending along the eastern border of the Norwich range, in the belt in which the Bristol mine occurs, and in the micaceous schist range of South Coventry, Mansfield, and Chaplin, north of New London.

The ores comprise native copper, the green and blue carbonates, and chalcopyrite and bornite. The native metal occurs in the usual platy masses, jagged nuggets, and seams and knots in the trap rocks or the adjacent sandstones. According to Shepard ${ }^{c}$ it occurs at Hamden and Farmington. Bornite occurs in the quartz veinlets cutting the trap rock of the Rocky Hill quarries at Hartford and at Winsted. It is the chief ore of the Bristol copper mine.

\section{HARTFORD COUNTY DEPOSITS.}

$$
\text { SIMSBURY (NEWGATE) MINES. }
$$

Copper glance (chalcocite) is the chief ore mineral at the Simsbury copper mines in the eastern part of Granby Township, New Haven County. The Simsbury properties are probably the oldest

a Percival, J. G., Geology of Connecticut, 1842, pp. 317-318.

o Op. cit., p. $47 \%$.

c Shepard, C. U., Rept. on Geol. Survey of Connecticut, 1837, p. 41. 
copper mines of America, being first worked under a charter granted in 1709, having been operated for about half a century. The property was purchased by the State about 1773 and used as a prison for 60 years, from which fact the main working became known as the Newgate mine. It was eventually sold and was acquired in 1830 by the Phoenix Mining Co. The ore is found in "a fine-grained yellowish sandstone of peculiar character, which here appears to prevail through an extent of 2 or 3 square miles. The ore has been observed in several places in this formation, occurring in beds of greater or less extent, as well as in nodules and strings." Trap rock forms the trap conglomerate ridge south of the Newgate mine. ${ }^{a}$

\section{HIGLEY MINE.}

The Higley mine lies $1 \frac{1}{2}$ miles south of the Newgate mine. The ore, like that at the Newgate mine, occurs impregnating a bed 2 feet thick, dipping eastward at an angle of $25^{\circ}$. Besides chalcocite the green and blue carbonates and red oxides occur. Bornite also occurs at the opening.

\section{BRISTOL MINE.}

The Bristol copper mine is the only one in the State that has been successfully worked. The ore occurs in a well-marked contact deposit at the boundary line between Triassic sandstone and schistose rocks.

The contact runs northeast and southwest, has suffered great decomposition from mineral solutions, and has been largely kaolinized. A broad band of this decomposed material, 30 to 120 feet wide, lies next the sandstone and contains disseminated ore. Then follows micaceous and hornblende slates, with horses of gneiss here and there. The slates are much broken by movements that have formed cavities for the ores. It is reasonable to connect the stimulation of the ore currents with the neighboring trap outbreaks. Unusually fine crystals of chalcocite and barite have made the mine famous the world over. While at one time a source of copper, for many years it has been unproductive. ${ }^{b}$

The following notes condensed from Richardson ${ }^{c}$ on the history of the mine show the conditions existing in 1854:

The copper mine in Bristol was opened in 1839 and worked from 1847 to 1854 , reaching a depth of 240 feet and yielding over $\$ 200,000$ worth of copper in that period. The ores occur in a well-defined vein in a hill composed of gneiss and mica slate, the hill rising 500 feet above the red sandstone plain or valley. The vein has a course of $\mathrm{N}$. $35^{\circ} \mathrm{E}$., is 80 feet thick, has a hanging-wall band of gneiss and a

\footnotetext{
a Shepard, C. U., Rept. on Geol. Survey of Connecticut, 1837, pp. 41-42.

${ }^{b}$ Kemp, J. F., Ore deposits of the United States, 1st ed., 1893, pp. 153-154. Silliman, B., and Whitney, J. D., Am. Jour. Sci., 2d ser., vol: 20, 1855, p. 361 .

- Richardson, C. S., Min. Mag., vol. 3, 1854, pp. 251-254.
} 
footwall composed of black and gray mica slate and black gneiss. The dip of the foot wall is $50^{\circ}$. The vein contains horses of "granite," the largest a rhombohedron 50 feet long, 40 feet thick, and 80 feet deep. The purest ore occurred in solid masses against this rock, with films of vitreous copper running in for 2 feet. The ore consists of bornite, which in its pure state contains 65 per cent copper and occurs in vugs and veinlets 1 inch to 5 inches across and as an impregnation associated with chalcopyrite and glance, this low-grade rock yielding a 5 per cent concentrate carrying 50 per cent copper.

In 1854 the mine was yielding every month 18 to 24 tons of ore worth $\$ 175$ a ton, the ore being treated in jigs, the concentrates carrying 41 per cent copper and the slimes 18 per cent copper. It was observed that ore occurs where black gneiss approaches the granite horses. The gneiss is banded and shows a vertical slip or slide and the more common mica slate of the neighborhood.

NEW HAVEN COUNTY DEPOSITS.

Near Mount Carmel, a few miles north of New Haven, an old working, once known as Tallman's mine, exists in Hamden Township, the ore occurring along the contact between trap and sandstone. In 1835 the incline was 50 feet deep. A crosscut 100 feet long driven through red marly sandstone was inaccessible. ${ }^{a}$

In southeast Cheshire a 3 -foọt dike of trap rock cuts sandstone, and both rocks contain impregnations of chalcocite with barite and copper carbonates. This property was mined in 1812 and again in 1836. Similar ores occur a mile to the west, and also at a locality 2 miles from Walcottville.

The pyritic quartz veins found at a number of places $^{b}$ and the Trumbull topaz-fluorite vein all carry chalcopyrite with galena.

At Carmel Center, 10 miles north of New Haven, a property opened by Mr. R. T. Townsend has furnished very fine specimens of native copper, copper oxides, and chalcopyrite in a hornblende gangue.

The following notes on the Stevenson mine at Bowers Hill, in Oxford, have been supplied by E. C. Eckel:

Copper pyrite impregnates the upper 6 inches to 1 foot of a 6 -foot bed of highly crystaline limestone. The limestone is overlaid by hornblende schist, thinly foliated, and the entire series dips $25^{\circ}$ to $30^{\circ}$ NW., striking about N. $65^{\circ}$ E. An inclined shaft 5 feet wide by 5 feet high follows down on the ore to a depth of 125 feet on the dip. The ore bed is said to yield 20 per cent to 30 per cent chalcopyrite. Andrew B. Hendryx, of New Haven, Conn., is principal owner. 


\section{NEW YORK.}

The High Falls and other pyrite mines at Pyrites, in St. Lawrence County, produced small amounts of copper in their early development, the pyrite shipped in 1885 carrying 3 per cent of copper. The mines have been steady producers of low-grade ( 26 per cent) pyrite for the Cleveland market for many years, ${ }^{a}$ but no return of the copper ore produced is available.

Near Ellenville, Ulster County, a deposit of pyrites was worked in 1885. The vein is 2 to 3 feet wide and carries traces of copper. It consists of pyrite lenses conformably intercalated in metamorphic schist-the "Oswegatchie series," of supposed pre-Cambrian age. The rocks strike northeast and southwest, and pyritic deposits occur for 4 miles, extending from the Cole mine, which lies 4 miles north of Gouverneur, north to the High Falls mines. The ore consists of pyrite with a quartz-feldspar gangue, with pyrrhotite at High Falls. There are three producing mines, the Cole, Stella, and High Falls. ${ }^{b}$

\section{NEW JERSEY.}

\section{HISTORICAL NOTES.}

The copper deposits of New Jersey were worked to a small extent in colonial days, chiefly by short tunnels or by quarrying out bunches of rich surface ores. Deposits in Warren County were mined in a small way in the seventeenth century by Dutch settlers and during Washington's New Jersey campaign the Revolutionary Army, which made its winter camp on Watchung Mountain, near Bound Brook, obtained from the bed of copper ore outcropping at that place enough metal to make a brass cannon, which was afterwards used in the siege of Yorktown. Early in the nineteenth century the Griggstown, Somerville, Plainfield, and Arlington localities were known and worked. In 1824 an expert smelterman from Germany installed and worked a smelter near Bound Brook, and a few years later operated a small furnace near Belleville, N. J., the ore coming from the Schuyler mine, which was worked at intervals for the remainder of the century. Small furnaces were built in at least a dozen different places, and were, for those days, successful. Along Wachung Mountain, from Plainfield west and north to Raritan River, the ore bed was opened by tunnels and open cuts, whose dump heaps and pits, now more or less overgrown by vegetation, are clearly recognizable. The writer has counted 21 of these old workings in a distance of $4 \frac{1}{2}$ miles along the mountain from Chimney Rock (Bound Brook) westward, and has also seen the ruins of three smelting furnaces.

- Mineral Resources U. S. for 1885, U. S. Geol. Survey, 1886, p. 504.

${ }^{\circ}$ See Eckel, E. C., Bull. U. S. Geol. Survey No. 260, 1905, pp. 587-588. Also Brinsmade, R. B., Eng. and Min. Jour., vol. 80, 1905, pp. 770-771. 
The period of greatest activity in the Watchung Mountain region was from 1825 to 1850 . For the 30 years succeeding, the Arlington (Belleville) was the only mine worked in a commercial way. About 1880 the American Copper Co. was organized and acquired numerous small holdings, embracing the woodlots of farmers, scattered along the front of the mountain back of Somerville and Bound Brook, and the old workings mentioned above. These properties were worked as a whole until 1882, when operations were suspended, as the optimistic expectations of the promoters had not been realized. In 1889 exploratory work was resumed and continued for several years, but it was not until 10 years later that the high price of copper, leading to a general renewal of interest in copper properties, caused this property and others at several different localities to be reopened and exploration and development to be resumed.

In 1904, in sinking on the ore bed of the Somerville, N. J., mine, it was discovered that with depth the carbonate and oxide ores gradually passed into native copper, occurring not merely as sheets but disseminated through the rock. This discovery is new in the history of New Jersey and if this change is general and permanent it indicates a possible new era for the New Jersey deposits.

\section{GEOLOGIC RELATIONS OF THE DEPOSITS.}

The red-sandstone series of New Jersey consist essentially of red shale and sandstone, with associated white and gray sandstone and gray shale. The series, which is known as the Newark group, extends from Connecticut southward to Virginia. It contains fossil remains, which determine its age as Triassic, and is furthermore characterized by gigantic footprints of great reptiles. That the rocks were deposited in shallow estuaries, like the bays of our coast, is indicated by mud cracks, raindrop impressions, and the reptilian tracks already mentioned, as well as by the character and color of the rocks themselves. The country in which these rocks alone occur is of but slight elevation.

The trap rocks are basic igneous rocks of very uniform chemical composition but of different physical textures, ranging from the basalts and dolerites of the Watchung Mountains to diabases. The trap rocks of the Watchung Mountains are lava flows contemporaneous with the sandstones. The other trap rocks of the State, whose most familiar example is seen in the Palisades of the Hudson, are intrusive sheets. The smaller intrusions commonly follow shaly bands and often persistently adhere to a single horizon. The rocks adjacent to such sheets show the effects of heat and steam in the baking and alteration of the sediments, but such contact metamorphism is usually confined to a narrow band. Both sandstones and trap sheets are generally tilted at gentle angles and are folded in 
synclines and anticlines. The trap rocks form the ridges and mountains of this part of the State, their superior hardness enabling them to resist the erosion that has carried away so large a part of the shale and sandstone areas.

The trap rock is dark bluish gray when freshly fractured, but turns greenish on exposure. It has an even-grained, compact texture and consists of abundant pyroxene (probably malacolith, an ironlime-magnesia pyroxene low in alumina) and of plagioclase feldspar (labradorite), in part altered to prehnite. The pyroxene and an original olivine has altered to chlorite, giving the dried rock. a greenish tinge. Some magnetite is also present. Analyses 7 and 8, page 48, show the basalt of Watchung Mountain, Orange, N. J., and the diabase of New Haven, Conn., to be rocks of essentially the same chemical composition.

The trap sheets and the ore bodies are very regular. The Somerville ore bed underlies the trap for a distance of at least 8 miles.

Above the trap the sandstones are impregnated, but less regularly. Thus at the Arlington property the ore does not occur in a well-

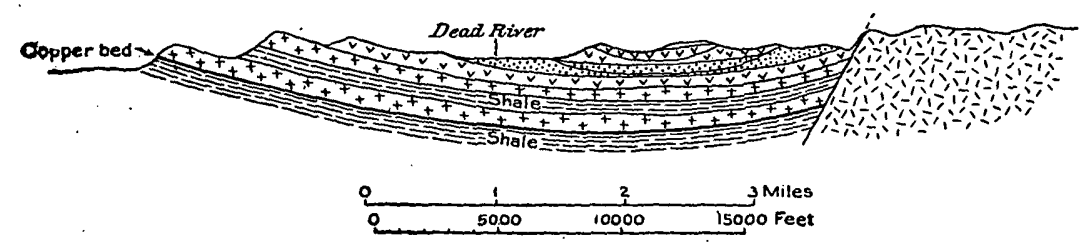

Watchung Mountain, near Somerville, N. J., showing copper-

Figure 3.--Section across Watchung bearing bed.

defined bed or vein, though it is confined to the sandstone for 15 or 20 feet above the trap sheet, occurring in pockets or bunches and seams which ramify through two thick layers of sandstone and a thin bed of shale. There are numerous (slight) faults in the deposit, and it is at these points and in connection with small trap dikes that some of the richest ore is found. Near the contact the sandstone is very generally though slightly impregnated with copper. The grayish sandstone above the traps of Watchung Mountain is similarly impregnated. The structural conditions at Griggstown and the many other localities in the State where copper is found are similar.

\section{ORE DEPOSITS.}

Copper minerals occur at many localities in New Jersey in the crystalline rocks and the red sandstones.

Except for the copper ores in the Paleozoic red sandstone in Pahaquarry Township, Warren County, which were mined by the early Dutch settlers and were recently reopened (see p. 54), the ores in the red sandstone areas are confined to Triassic rocks and are still 
further limited to trap intrusions and extrusions in that series. Deposits of past or prospective commercial importance occur only in connection with such rocks.

As shown by Dr. Cook ${ }^{a}$ many years ago, the New Jersey copper deposits are not veins, but impregnated beds, either of sandstone above the trap rocks or of altered shale beneath them. Where the trap is intrusive, as at Arlington, New Brunswick, Griggstown, etc., the adjacent rocks are more or less altered by the heat of the igneous magma to contact metamorphic rocks, hornstones, etc. At Rocky Hill, glance and hematite occur under conditions that suggest a hydrothermal origin, and at Arlington the conditions also indicate reimpregnation of the overlying rocks, with subsequent slight alterations and migrations of the copper.

\section{THE ORES.}

The copper ores of New Jersey. are commonly the oxides, carbonates, and silicate of copper; cuprite, malachite, and chrysocolla are the most common, the black oxide, tenorite, and the blue carbonate, azurite, being rare. Associated with these ores, sheets and masses of native copper occur in joints and crevices of both trap rock and ore bed. Glance (chalcocite), commonly associated with calcite, is also found. The other sulphides are rare, bornite occurring as a secondary product in the bowlders of decomposed rock of the subsoil at Chimney Rock, and chalcopyrite being found at Arlington and other localities as a secondary mineral filling fractures. Native silver occurs at several localities; it is associated with chrysocolla at Arlington, Somerville, and Raritan River.

In studying the occurrence.and distribution of the ore minerals it is necessary to distinguish the normal ore content of the vein (either unaltered or in its decomposition products) from the ore of secondary fractures extending down to considerable depths. Fractures carry surface waters and produce carbonate ores far below their normal level, but such ores are not a normal constituent of the deposit. The ores of the upper parts of the Somerville deposit are mainly red oxide of copper in nodules and bunches in the ore bed, with films of native copper in joint cracks. The cuprite varies considerably in luster and color; bunches of several pounds weight occur near the surface, where they are commonly surrounded by a crust of malachite and chrysocolla, often grading into a red or green jasperoid. In passing downward along the dip the carbonates disappear and red oxide is more abundant. This, in turn, changes to an earthy orange-colored powder or an aggregate of minute needles of copper oxide, associated with native copper, the latter becoming more and more abundant in depth until no oxide is seen. 


\section{MINES.}

\section{CONDITION.}

The workings early in the century, some of them several hundred feet long, were abandoned because they could not be kept free from water by hand pumps, and at most of the deposits the old workings are inaccessible, tunnels being caved and filled with water and shafts blocked. The extent of the early workings, however, is known from available records and can be inferred from the great dump heaps of waste and low-grade ore. In 1905 the only underground workings accessible were those of the Arlington, Griggstown, Somerville, and Pahaquarry properties.

So far as known, the Somerville property, which is called the American mine, is the only one that has penetrated below the water level and below the zone of surface oxidation and alteration. For this reason the discussion of the genesis and permanency of the New Jersey ores, and of the mineralogical changes they undergo, is in large part based on the facts observed and the specimens collected at this mine. The matter is of great significance, as the commercial value of these low-grade deposits depends entirely upon it.

\section{SCHUYLER MINE, AT ARLINGTON.}

At Arlington the old Schuyler mine is now the property of the Arlington Copper Mining Co. Nearly $\$ 250,000$ was expended here between 1900 and 1905, mostly in the erection of an expensive reduction plant of unique design, with good machinery, but of no metallurgical value. It was designed to treat 125 tons a day, but when run on the ore it was found that the tanks would not hold the solution and the copper would not precipitate.

The property comprises 150 acres, in part honeycombed by old workings, with 42 shafts, all but one now filled, and three drain tunnels, one of which drains the mine to the 100-foot level. Two inclines have been run in from the face of the sandstone bluff overlooking the Newark meadows. One incline is 220 feet long and connects through old workings with an old shaft. The second drift is only 80 feet long. ${ }^{a}$

\section{GRIGGSTOWN MIINE.}

LOCATION.

The Griggstown mine is in a hilly tract about 8 miles north of Princeton and about 3 miles north of Rocky Hill, the terminus of a branch line of the Pennsylvania Railroad running north from

a Geol. Survey New Jersey : Ann. Rept. State gcologist for 1900, 1901, pp. 209-212. 
Monmouth Junction. The high trap ridges, locally known as Tenmile Mountain and Rocky Hill, are cut through by Millstone River, the principal tributary of the Raritan, and are excellently exposed near Rocky Hill. The copper property lies in the open, smooth, cultivated fields on the east side of the river, about 150 feet above' its bed and 200 feet above sea level. A wooded area with an outcrop of trap forms the summit of the hill, the mine being located on the smooth rounded slopes that extend downward to the Raritan Canal.

The property was worked early in the nineteenth century, and was cleaned out and reopened some years ago, but has produced no copper lately. The workings consist of several vertical shafts, now caved, a drain tunnel 1,200 feet long, and a new incline shaft, together with stoped-out chambers. The main vertical shaft is said to be 150 feet deep, but when visited was filled with water to the level of the old drain tunnel, and the accessible workings were all above this point.

\section{GEOLOGIC RELATIONS.}

But two rock types are found in this vicinity-trap (or diabase) and red shales of the Newark group. The trap is a coarse-grained bluish-gray rock of very uniform character. It forms a thick, gently inclined sheet lying conformably with the red-shale beds into which it was intruded. These shales are more or less highly altered near the igneous rock, in some places for a distance of 100 feet vertically above the sheet. This alteration is particularly marked at the copper mine.

The deposit consists of an ore seam from an inch to a foot or more thick, occurring in and conformably to shales altered by contact metamorphism resulting from the intrusive sheet of trap. These shales are hard and dense and have lost their fissile character and may more properly be called hornstones. A noticeable feature of these rocks is a peculiar spotting, due to the presence of dark-colored spherical segregations, which are scattered singly or in groups through the dark purple rock. These segregations are of many sizes, ranging from minute pellets to globes an inch across, but most of them are about one-fourth.inch in diameter. They consist of green hornblende, in part altered to chlorite, and are commonly surrounded by a rim of bleached rock 1 millimeter wide. This is the rock which carries the ore, but when mineralized the groundmass is rotted and altered to a pale, flesh-colored or white, kaolinlike mass, in which the dark-green spherules resemble plums in a pudding. 
THE ORES.

The ores consist of native copper, red oxide of copper (cuprite), black glassy-looking tenorite (black oxide of copper), malachite, chrysocolla, copper glance, and rarely bornite. The ore seam also carries considerable micaceous hematite. These ore minerals occur in the leached and white altered hornstone.

The ore seam appears to be a bedding plane of the old shales, along which slipping has occurred during the tilting of the beds. It is, so far as observed, entirely conformable to the shales, and dips west at an angle of $10^{\circ}$. The trap sheet exposed on the summit of the ridge passes underneath the copper bed, and the exact thickness of rock between the ore and trap was not determined. The ore seam does not outcrop and the mine dumps are in a cultivated field, no rock appearing in place. However, the inclined shaft exposes an excellent section of the altered shales overlying the ore, and the ravine scoring the slope, from which the long drain tunnel was driven nearly a century ago, also shows good exposures of the shales.

The ore seam consists largely of altered, leached, and whitened rock with patches of ore, and of a soft blackish material which proves to be chlorite. Cracks run down and connect with chlorite bunches in the rock below the ore seam proper, but no copper ore was found except in the thin seam mentioned. Samples of the soft chlorite, which in places forms a layer several inches thick, showed no visible copper minerals and on assay yielded only 0.69 per cent of copper. The ore follows fractures crossing the ore seam proper and is not uniformly distributed. The ore body woirked consists of bunches of glance and oxidized ores, which cover irregularly elliptical areas of possibly a couple of hundred feet across. In mining so thin a seam the underlying waste had also been broken down. There is said to be a vertical vein of copper ore exposed in this shaft, and also a lower layer, a sheet of ore on the 150-foot level, but no evidence of this could be obtained on account of the water. Several nearly vertical fractures intersect the ore seam near the incline. These fissures are filled by crushed and altered rock and carbonates, and are said to carry gold, but assays made in the Survey laboratory failed to show even a trace of this.

The scientific interest of this deposit is very great, on account of the evident reducing action of the hornblende and chlorite on copperbearing solutions, but the discussion of the origin of the ore involves a consideration of the several cycles of uplift and erosion to which the region has been subjected since Triassic time and of the accompanying movements of percolating waters, which are supposed to have derived the copper through the alteration of the trap from a fresh basaltic lava or diabase sheet to its present condition. 
AMERICAN MINE.

WORKINGS AND EQUIPMENT.

A copper-bearing bed, which outcrops for several miles along the escarpment of Watchung Mountain, has been worked by the American Copper Mine Company. The main workings are 3 miles from Somerville, at the site of the old Bridgewater mine, where an incline shaft 1,300 feet deep (on the dip) has been sunk on the ore bed, with 1,800 feet or so of drifting. The drifts are 30 feet xpart, alternating on each side, thus blocking out the ground in the same manner as in coal mining. No timber is used save for a few yards near the surface, and no shattering of rock has as yet occurred, the great trap sheet, 600 feet thick, forming a perfect roof when supported by ore pillars and a cribbing of waste. The development is done with power drills, the softer fissile shale beds beneath the ore being first undercut and extracted, as in coal mining, leaving a breast of ore easily shot down and free from waste. Thus far a large amount of ore has been blocked out, but it is low-grade; only below 600 to 700 feet, the depth where the change to native copper occurs, can an ore averaging $1 \frac{1}{4}$ per cent be profitably extracted. It should be stated, however, that systematic sampling by the mine superintendent is said to show over 2 per cent of copper.

The surface plant consists of a 5-drill Rand compressor with 80horsepower boiler, running two drills and the pumps, and a hoist with 12-horsepower Lidgerwood engine. The 50-ton mill is equipped with 60-horsepower boiler and engine, a crusher, two sets roughing rolls, drying screens, a sizer, and two Wilfley tables. Experiments in leaching the oxidized ores were made, but as the ore has changed to native copper in depth and this change appears to be permanent, the problem of treatment is greatly simplified.

The concentrate from the Wilfley tables carries 60 per cent copper as shotlike particles.

\section{ORE DEPOSITS.}

CHARACTER AND RELATIŌNS.

- The Watchung Mountain copper deposits are by far the most extensive in the State. Their character and occurrence throughout are apparently uniform, so that the deposit at the American mine, near Somerville, is typical, and its description will xpply to all the Watchung Mountain deposits. The ore bed is a dense, firm, nearly uniform, purple rock, having a texture like that of a brick on cross fracture, and differing markedly from the underlying shales in its massiveness and uniformity. The bed ranges from 8 inches to $2 \frac{1}{2}$ feet in thickness. The rock also differs markedly from the shale in color, being 
purplish instead of red. This purple tint is characteristic, and even after a half century of weathering on dump heaps is readily recognized. The earlier geologists recognized the changed appearance of the shale and assumed it to be due to contact metamorphism. It is quite possible that there has been a slight baking, for, although the evidence is conclusive that the Watchung basalt sheets originated as lava flows, spreading out over the tidal flats or shallow reaches of a great estuary, yet the same alteration which has been observed under lava flows in the Yellowstone Park and elsewhere is sufficient to produce the changes seen here. That this alteration is not wholly due to mere baking is shown by experiments with the underlying shale, and it is believed that later alteration has taken place. Especially interesting is the porous condition of the rock, which contains a great number of lenticular cavities such as might be made by sticking the point of a penknife into a soft substance. Besides these open gash spaces there are many small irregular cavities. This porous texture is characteristic of both the purple rock and of the ore-bearing white spots in it down to 1,300 feet from the outcrop.

The copper minerals are not uniformly disseminated through the ore bed, but occur only in white spots or blotches irregularly scattered through the purple rock. In the deeper workings these spots, whose white or gray tint is in marked contrast to the surrounding purple rock, invariably carry ore, higher up as oxide dust lining minute cavities, and lower down as small nuggets and pellets of native copper disseminated through the light-colored rock.

As a rule the copper partly or wholly fills these pores in the white blotches of the beds. In large part the rock of the ore bed at 1,300 feet and below is solid, the pores being filled by calcite, the significance of which and of the association of calcite and native copper will be discussed later (p. 54). Throughout most of the workings, however, not only of the American mine but of the adjacent properties as well, the rock of the ore bed is distinguished by the abovementioned pores.

The shale beneath the ore bed, where exposed by weathering, is soft and friable. In the mine workings it is compact and hard and is composed of different layers, which thin out abruptly, are often separated by micaceous partings and streaks, and vary in grain. Immediately beneath the ore the shale is very fine grained and dense, but shows calcite specks, and when treated with dilute acid shows an abundance of pores, often irregularly round and branching, of the same shape as many of the smaller particles of native copper in the ore. 
The base of the trap rock is frequently amygdaloidal at the contact, the smaller cavities being filled by calcite, the larger sometimes with quartz, calcite, laumonite, and manganocalcite.

The trap rock at and for several inches from the contact shows considerable alteration. The rock contains many small amygdules of calcite the size and shape of fine bird shot. Six inches from the contact it is a nearly normal dark-gray color, greenish from chloritic staining when moist, but to the eye quite fresh and unaltered. At 3 inches from the contact the rock is slightly lighter, increasing gradually to a well-marked brownish line a millimeter thick at $1 \frac{1}{2}$ inches from the contact. A second chocolate-colored line is oneeighth inch from the first, and a third is one-sixteenth of an inch, inside of which the lines become indistinct and merged in a general brown staining of the rock for half an inch, with more abundant calcite amygdules. The trap for an inch from the contact is much lighter colored and shows a great abundance of calcite amygdules, mostly of irregular shape and bordered or incrusted with shells of native copper.

An examination of thin sections of the ore under the microscope shows that the purple rock is in reality an altered tuff. Prof. Joseph Barrell, who has kindly examined it, concludes that the rock is a vitrophyric andesite, showing small broken feldspar crystals, and shreds of muscovite in a glass base stained deep red by ferric oxide. The sharp feldspar crystals, in marked distinction to the isotropic groundmass, seem to indicate that this rock is a chilled margin of the diabase. The ore bed shows micaceous partings and streaks of compact very fine-grained shale and in places fossil mud cracks. A comparison of the chemical analyses of the ore rock with those of the underlying normal shales is shown in the table below.

The analyses were made by Mr. A. Borg, formerly the chemist of the American Copper Company and now professor of chemistry in the Cooper Institute, New York, and were furnished to me by the courtesy of Mr. Josiah Bond, former manager. The first column represents the trap rock, the fourth the ore. It will be noted that the large percentage of alumina and the very slight amount of alkalies present in No. 4 shows the rock to resemble a normal sediment. The ore proper-that is, the white copper-bearing spots in the purple gangue evidently results from a reducing action that produced the native copper and changed the red ferric oxide to the protoxide. Tests made in the Survey laboratory by Dr. H. N. Stokes on samples of these rocks showed the presence of ferric oxide in the red and the presence of ferrous iron in the white rock, a conclusion confirmed by an examination of thin sections under the microscope. 
Chemical analyses of rocks and ores, American Copper mine, Somerville, N. J.

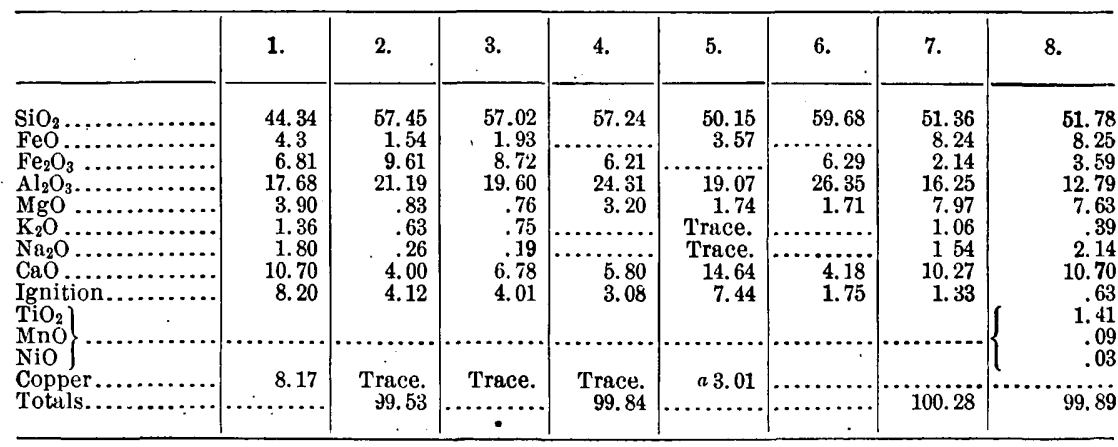

a Silver, 1.9 ounces, per ton.

1. Trap rock from above ore bed.

2. First shale layer below ore bed.

4. Purple rock of ore bed.

5. White spots in ore bed.

6. Ore.

7. Basalt; normal rock of Watchung Mountain, Orange, N. J. (Bull. U. S. Geol. Survey No. 148,1897 , p. 80 .)

8. Diabase, West Rock, New Haven, Conn.

Analysis 1 shows, in the high percentage of water and ignition, the low silica, and the relatively large proportion of ferric iron, that the rock is much altered from No. 7, which is the normal rock at Orange. It also shows normal alumina, alkalies, and lime, a loss of 50 per cent of magnesia, and a decided loss of silica. These changes indicate a leaching of the rock by alkaline waters, and the unchanged alkalies show that there was no available chlorine or sulphur to combine with and remove them.

The analyses of the shale are unusual in showing no alkalies, which is normal for a slightly calcareous clay shale.

Analysis 4 represents the normal rock of the ore bed. Its silica content is exactly the same as that of the underlying shale and unlike the trap rock. It also resembles the shale in having no alkalies, but differs from it in having much less iron, more alumina, with considerably more magnesia.

The mill tailings from the ore having been tested by several firms and declared to carry values in silver and gold, a sample was collected by the writer and a crucible assay made on a large charge by Dr. E. T. Allen in the laboratory of the survey. The result showed no gold, but 6.94 ounces silver per ton.

The alternation of the trap is evidently the result of normal hydrometamorphism, due to percolating surface waters.

THE ORES.

Copper glance (chalcocite) occurs in small quantities at numerous places in the mine, mainly as a secondary product in fractures. Below the zone of oxidized ores it occurs in and with calcite in 
joint fractures, in many places associated with sheets of native. copper.

The masses of white ore-bearing rock of the lower drifts $(1,300$ feet and 1,330 feet) also carry glance. In the purple rock surrounding the white ore the glance occurs as tiny bunches of glistening crystals, attached to the walls of the gashlike cavities. In the white ore the glance occurs in solid nucleal masses, dull on existing fracture surfaces, and surrounded by sooty glance (an alteration product), a substance which has also in many instances migrated and impregnated the porous rock about the cavity. The most significant feature. is, however, the presence of native copper about this altered glance, usually bordering it, whose very finely divided state and manner of

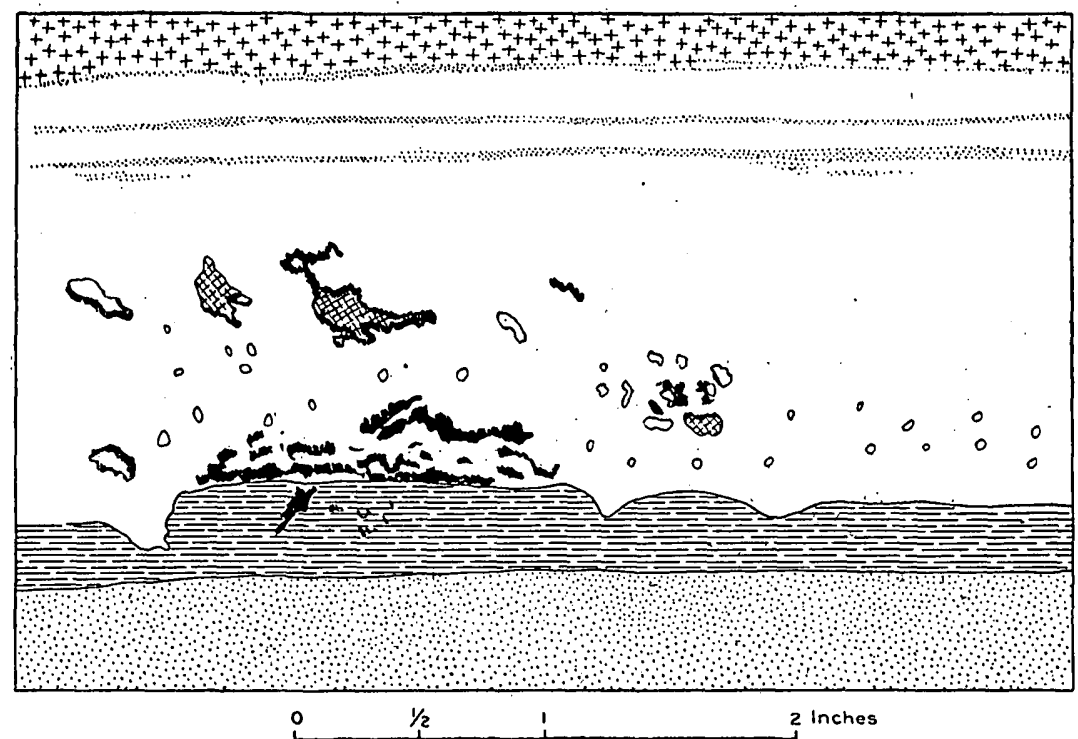

Figune 4.-Diagrammatic sketch showing occurrence of copper in contact rock at the American mine, Somerville, N. T.

occurrence show that it was reduced from the glance in place. Several of these spots of native copper, or of glance and copper, are surrounded by a halo of bleached rock, whose width is one-half the diameter of the copper particle, clearly indicating an alteration due to the product of the reactions involved in reducing glance to native copper. The glance just described is not associated with calcite, but occurs in cavities.

Glance also occurs in drusy masses and along joint fractures in a crystalline mass of calcite inclosing a mesh of very minute mossy hairs of glance. This association indicates the synchronous deposition of both materials. At present it appears as if this glance resulted from a reversed reaction-that is, from native copper and 
calcite being attacked, with removal of calcite and the deposition of glance. Later solutions attack the glance and reduce it in the white rock but not in the red rock. No native copper occurs in the red rock; that is, in the presence of ferric oxide. It is confined to the white rock, which contains ferrous iron but no ferric oxide. If the reduction depends on the ferric oxide, the occurrence of native copper is purely local.

Native copper occurs incrusting and sheathing calcite amygdules in the trap and the similar calcite masses in the white ore. The mineral collection at the mine includes specimens of native copper pseudomorphic after calcite.

This occurrence of native copper in white, bleached spots in the ore bed is characteristic of the great copper deposits of the red sandstones of Corocoro, Bolivia, ${ }^{a}$ and a similar occurrence was noted in this country in 1902 by Emmons. ${ }^{b}$ Native copper pseudomorphic after calcite also occurs at Corocoro and at Lake Superior.

GENESIS OF THE ORES.

Source and deposition of the copper.-The genesis of the ore appears to have been simple. The diabase commonly carries a small amount of copper, partly, it is believed, as primary pyrite and chalcopyrite, these minerals being recognized in similar rocks from other localities; and probably partly in the ferromagnesian silicates. Careful chemical tests made on large quantities of the diabase from Somerville showed that it carried one-fortieth of 1 per cent $(0.025$ per cent) copper. ${ }^{c}$ Specific gravity separations (made by the writer) of the basic ferromagnesian particles in the diabase, crushed to go through a 100-mesh screen, followed by qualitative calorimetric tests, showed that this basic portion contained considerably more copper than the rock as a whole.

The rock exposed in the Watchung Mountain quarries is a typical diabase, having blind joints, whose presence is betrayed on exposed faces by bright-red bands composed of material which in places is sufficiently abundant to form a red clay in the joints. It is reported. that tests made of this clay by Mr. Borg and other chemists showed red oxide of copper, but the coloring matter in specimens collected by the writer proved to be ferric iron. Plate $\mathrm{V}$ shows two of these specimens, in which the joints have served as channels for circulating water, with concurrent alteration of the rock adjacent to the joints and the leaching out of material and its concentration close to the

a Forbes, David, Quart. Jour. Geol. Soc. London, vol. 17, 1861, p. 41.

b Oral communication.

c The writer is indebted to Mr. Josiah Bond, former manager, for this information. The determination was made by $A$. Borg, former chemist at the American mine, Somerville, N. J., and later professor at Cooper Union Institute, New York City. 


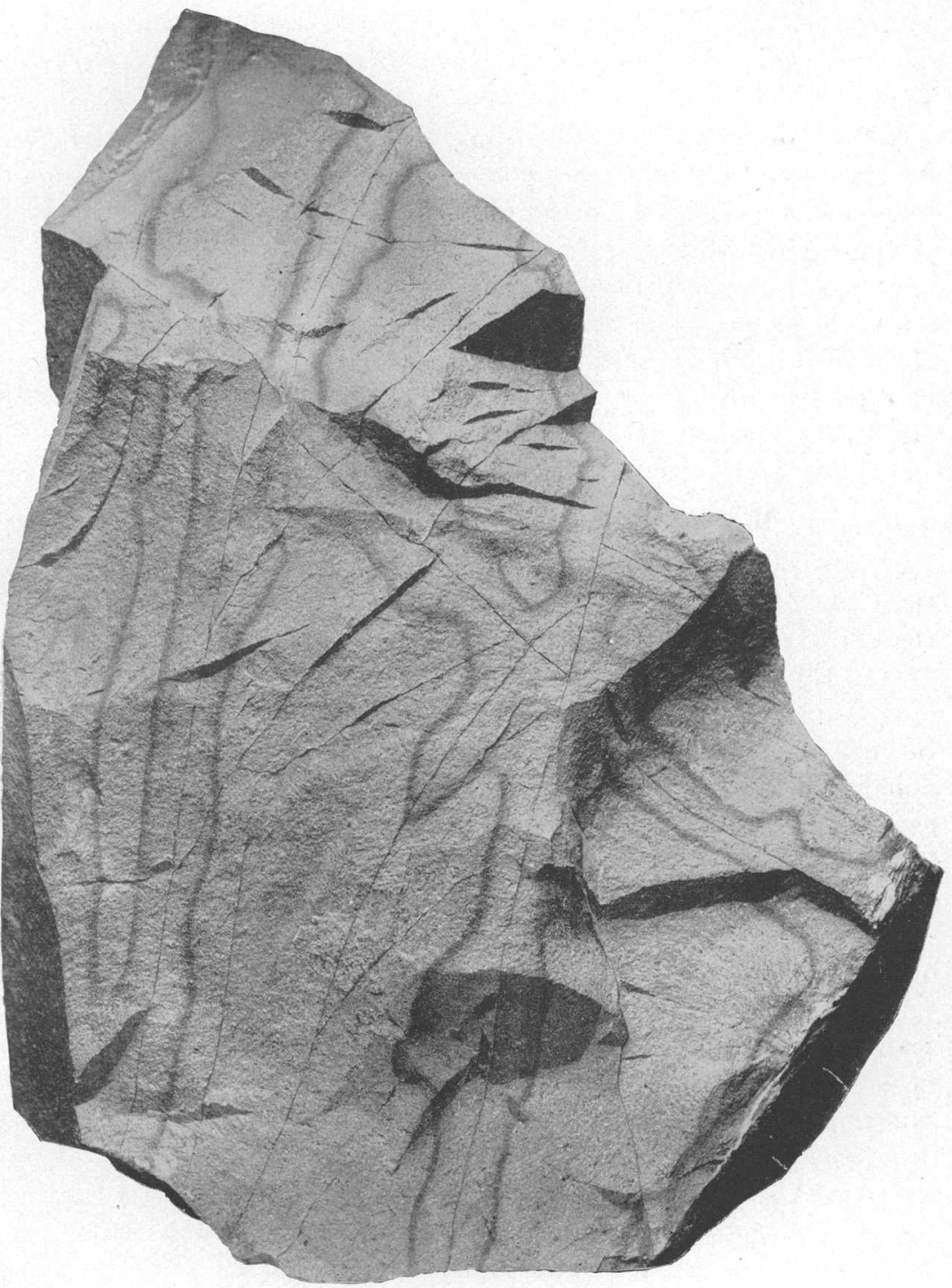

DIABASE FROM COPPER DEPOSIT NEAR SOMERVILLE, N. J.

Showing occurrence of copper and iron in cracks. See page 50. 
joint. Many of these joints are, however, microscopic or potential joints and of course are not discolored. It is believed that the circulation of the water in the diabase is mainly along the joints, and that the material leached out comes from the rock on each side of the fractures.

A further proof that the source of the copper is in the diabase is shown in the association of all the copper deposits of the Mesozoic region of New Jersey with intrusions of diabase. Where such association exists there is evidently no need to compare these ore beds with the Permian red beds of Europe. The hypothesis that the copper was precipitated by solutions in the shale mixing with solutions from the diabase is not in accord with the observed facts. The presence of organic matter, animal and vegetable, both in the New Jersey deposits and in those of red beds everywhere, is sufficient to account for the preciptation of the copper. In Bolivia, Germany, and New Jersey the native copper of the deep-seated workings is found only in association with the white or green spots or patches in the red sandstone-that is, places where the ferric oxide has been reduced to a ferrous condition. In the New Jersey deposits the diabase near the copper ore is always altered. It has suffered from what Lindgren has designated hydrometamorphism. Infiltrating waters have attacked the ferromagnesian minerals and, presumably, have dissolved the copper and taken it into solution. During past periods, when base-leveling has taken place, the drainage differed from that of to-day and the slowly circulating waters at one period moved upward and at another period downward. Whatever their course, the waters coming from the diabase carried a minute content of copper derived from that rock, either as sulphate or, perhaps, more commonly, in alkaline carbonate solutions. The waters encountering the incasing sandstones and shales lost their copper by a reaction of the organic matter present. The recent discoveries of Sullivan have, however, shown that both true clays and crushed rock act chemically and extract the copper, forming a silicate which may in turn be altered to another ore. This chemical action is so prompt and so vigorous that it is certainly an important factor in ore deposition.

The presence of glance and native copper in the deep levels of the American mine in New Jersey indicate, however, a reduction from solutions carrying copper sulphate, the waters being possibly a mixture of alkaline carbonates and alkaline sulphates.

Alteration.-Secondary alteration of the ore is seen in every stage in the workings of the American mine. The ore bed at a depth of 800 feet below the surface, measured on the dip, carries native copper and minute specks of glance in the nodular masses of white rock mentioned above. At a little higher level this ore is seen to be altered to orange-colored copper oxide in little tufts of needle-like crystals 


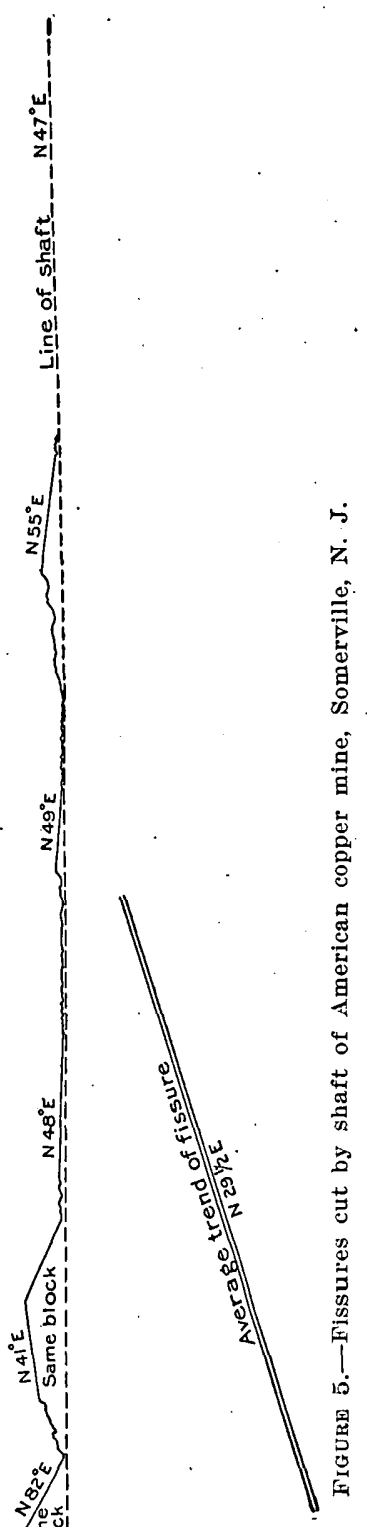

in little cavities; at higher levels the oxide is found as a coloration disseminated through the rock; and at still higher levels as little concretions, which increase in size toward the surface until at shallow depth small balls and kidneys of red oxide ore are found. Still nearer the surface the outer parts of these concretions are converted into malachite. Quite rarely the rocks immediately beneath the surface soils carry bornite.

It is realized that this distribution of the ore involves a second solution, with migration and concentration of the material, but each step and gradation of the process is observable in the Somerville mine, and the nodules and kidneys of oxide ore, for which the ore bed was formerly worked for a distance of 2 miles or more along the mountain front, go down for only 100 or 200 feet.

The copper ores occur both above and below the diabase sheets. In several deposits the overlying rock is a sandstone and the deposit is impregnated with brightcolored copper minerals. The solutions have penetrated the sand rock, but only that portion of it which lies close to the fractures. The diagram given by Darton, which at first glance indicates impregnation by magmatic vapors given off by the diabase at the time of its eruption, may be explained by the circulation of waters along the diabase contact under a low head and the checking of the water in the open spaces of the crushed sandstone, accompanied by a deposition of copper either by chemical reaction or by reduction due to organic matter.

Kemp ${ }^{a}$ notes that the comparison drawn by early investigators between the Lake Superior and New Jersey deposits is significant, although there is a very great difference of age. The Lake Superior deposits, however, do not

a Ore deposits of the United States, 2d ed., 1895, p. 168. 
pass into sulphides in depth except locally-for instance, at the Huron mine copper arsenide occurred-and in the Mamaisne mine near Sault Ste. Marie native copper changes to glance at a depth of 90 feet. At Corocoro, Bolivia, similar ores occur.

The relative ages of the native copper and of the glance in lower levels of the American mine is of much practical importance, for if the copper occurs as sulphide at a great depth the ore could not be treated so cheaply as if the copper were native. In other words, it is important to know whether the glance now found in the lower levels is secondary after native copper, or whether the two are contemporaneous. There is no doubt that at other localities the glance is due to reduction by carbon, and the native metal may be taken as the extreme form of this reduction. . The doubt led to the making of a series of tests on the samples from the deeper levels, taken at 200 -foot intervals from the 1,200 to the 3,600 foot levels, but the results are hardly conclusive. The lowest 200 feet contained only a trace of sulphur; from 3,200 to 3,400 feet the sample showed none; from 3,000 to 3,200 it contained 0.11 per cent. This increased to 0.18 per cent in the next 200 feet, but fell to 0.075 in next 1,000 (from 2,800 to 800 feet). From 1,800 to 1,400 feet the ore carried only a trace of sulphur, but at 1,200 feet it carried 0.06 per cent sulphur.

The lack of gradation in these analyses seems to be due to the proximity of the great fissure which cuts through the trap-rock between 2,600 and 3,200 feet. This fissure brings down percolating waters, and may have altered the native copper into sulphide.

Table showing sulphur content of ore from American mine.

$\begin{aligned} & \text { Depth in feet. } \\ & 3,600 \text { to } 3,400 \text { (lowest work, } 1,300 \text { feet) }\end{aligned}$
3,400 to 3,200 Trace.
3,200 to 3,000
3,000 to 2,800
2,800 to 2,600
2,600 to 2,400
2,400 to 2,200
2,200 to 2,000
2,000 to 1,800
1,800 to 1,600
1,600 to 1,400
1,400 to 1,200

Recapitulation.-The observed facts that bear on the discussion of origin of the Somerville deposits indicate that the basalt is chloritized as a result of ordinary hydrometamorphism. It is vesicular in places, the cavities now being filled with calcite amygdules. Native copper sheathing these amygdules occurs in the leached and green rock an inch or two thick which lies next above the contact, but only where 
the underlying rock of the ore bed is dense; where it is porous the copper is absent in the basalt but occurs in the altered shale.

The ore bed is an altered tuff beneath the basalt. It has a purple color, contains a large amount of ferric iron, and is distinguished by cavities whose shape, size, abundance, and inner surface closely resemble the pores of an ordinary red brick, suggesting a slight baking of a wet silt or mud. These pores are either open or partly or wholly filled by native copper below the zone of surface alteration; by a loose powder of orange-colored oxide at the transition line between oxidizing and deep waters; and by normal oxides encrusted by carbonates above this line. The native copper and most of the oxide ore is confined to patches of white bleached parts of the ore bed, irregularly distributed. In depth, the cavities of the white ore are filled by calcite sheathed by native copper, but other parts of the bad show fresh glance crystals in cavities in the purple ore and altered glance and native copper reduced from it in cavities in the white ore. The latter are surrounded by a halo of whitened gangue. The sheet copper of these bottom workings occurs in joints parallel to the bedding and near the trap contact; the native copper lies alongside of layers of black calcite, shot through with minute spicules and mossy fibers of glance.

These facts are believed to show that the copper comes from the basalt and that the solutions carrying it contained alkaline carbonates and precipitated copper and glance with calcite. If the copper came from the decomposing chalcopyrite of either the shale or basalt the solution would be acidic and the calcite would be attacked. Where organic matter, such as plant remains, occurred the copper sulphide would be reduced to native copper.

\section{PAFLQUARRY MINE, ON KITIATINNY MOUNTAIN.}

\section{EXPLOITATION.}

Near Delaware Water Gap, where Delaware River cuts through a long mountain ridge composed of uniformly and steeply tilted sandstones, there is a copper deposit, which was worked 200 or more years ago by the earliest Dutch settlers of the country. This property, long known as the Pahaquarry copper mine, is about 8 miles from the town of Water Gap and 10 miles from Stroudsburg, Pa., at a point known as Dimmicks Ferry.

The early workings were extensive, comprising a tunnel driven for a distance of 200 or more feet, with a crosscut at the end, and two inclined shafts, 60 and 40 feet deep, respectively, sunk on the bed, presumably following pockets of rich ore. The property was reopened and cleaned out in 1860, but the ore proving low grade all mining work was soon stopped. About 1900 another attempt was made to work the property, but without success. 
GEOLOGIC RELATIONS.

The ore-bearing beds occur in the red and gray sandstones of the High Falls formation, of upper Silurian age, which forms the second or northern ridge on the slopes of Kittatinny Mountain. The formation was formerly classified by the New. Jersey geologists as Medina sandstone, but has recently been determined to be of Salina age. It has an estimated thickness of 800 feet and consists of massive sandstones and interbedded shales. The strike is N. $20^{\circ} \mathrm{W}$.; the dip is $40^{\circ}$ to $45^{\circ} \mathrm{W}$., as observed in the ravine at the Pahaquarry copper mines. The shaly members show cleavage that dips at steep angles to the southeast, and are slaty, as may be seen at the copper mine. The harder, coarse-grained rocks show no cleavage, but exhibit numerous joint planes, which correspond to the cleavage planes seen in the more shaly. beds and were formed at the same time. The prevailing colors of the High Falls ("Medina") formation are red and brownish red, but grayish green rocks appear in it in places. At the Pahaquarry mine the rocks are locally gray. The texture varies, being fine at the bottom. The top of the formation is nearly all of red shale, split by cleavage, and carrying intercalated red and gray sandstones. The shale occurs in thin beds and the sandstone in thick beds. No fossils have ever been found in these rocks in New Jersey: Copper and iron pyrite have been found in this formation at a number of places.

The demarcation between the Shawangunk ("Oneida") conglomerate and the High Falls ("Medina") formation is seen at the Warren Slate Works. The strike at this place is N. $20^{\circ} \mathrm{W}$. and the $\operatorname{dip} 40^{\circ} \mathrm{N}$. The red rock continues subordinate and is fissured and occurs mainly on the lower western slope.

\section{THE ORE DEPOSIT.}

The region of Kittatinny Mountain has been known to be ore bearing for many years. The basal bed of the graat Shawangunk ("Oneida") conglomerate which forms the bold bluffs of the mountain is very pyritous. According to Dr. Cook, ${ }^{a}$ late State geologist of New Jersey, the lower few inches of this conglomerate carries gold over many square miles, in places to a value as high as $\$ 11$ a ton. Anywhere along the outcrop of the contact between the base of the conglomerate and the Ordovician ("Hudson") slate one can obtain pyrite ore that is rich in gold.

At the copper mine the ore beds outcrop in a ravine known as Mine Run, the lowest exposure being at an elevation of about 150 feet above the river. From this point to the height of 750 feet above sea level the rocks appear to be more or less continuously cupriferous. 
The portion of the formation that carries the copper consists of gray sandstones in beds from 2 feet to 6 feet thick, separated by reddish shales, usually massive and arenaceous, in beds from 6 inches to 2 feet thick. These rocks show a slight local disturbance with flexure near Mine Run, but in general the outcrops show an unusual uniformity of strike and dip. One of these outcrops, forming what is known as the "watershed," is conspicuously exposed, showing in the center a surface between 30 and 40 feet wide, and having been stripped for a distance of 2,000 feet: The strike of the red shale forming this "watershed" is N. $60^{\circ} \mathrm{E}$. and the dip is $43 \frac{1}{2}^{\circ} \mathrm{N}$. Several crosscuts expose good sections across the various ore-bearing strata, and old workings enable one to note the change in character of the ore in passing from the surface inward.

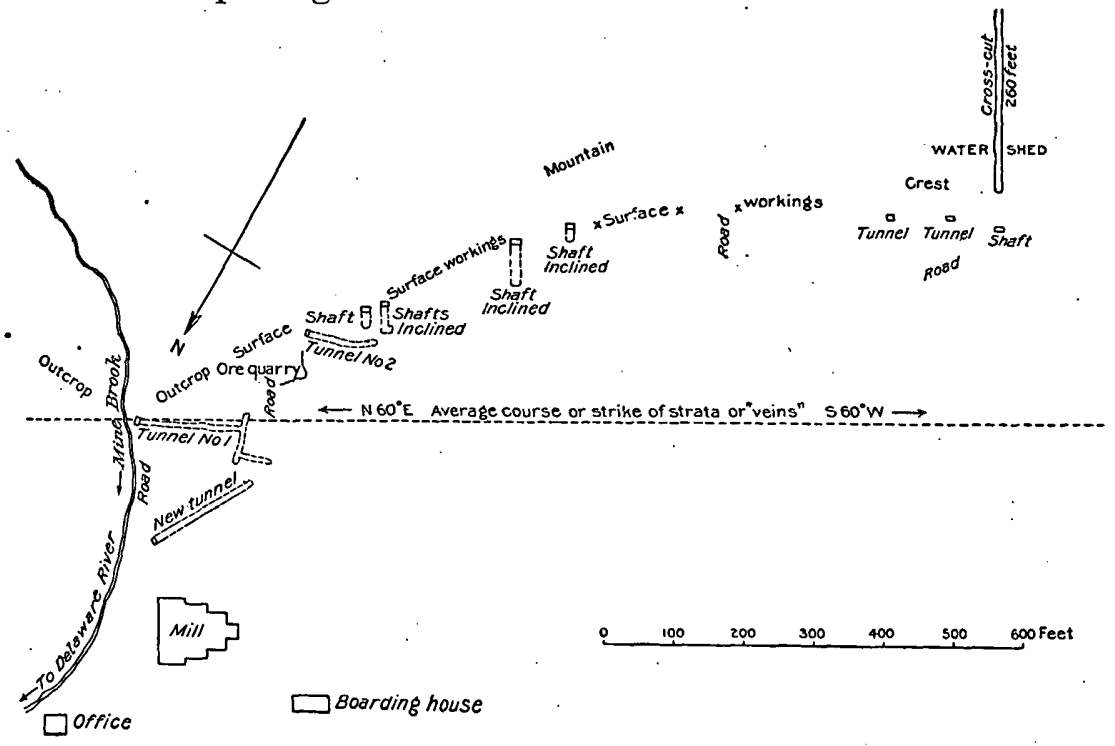

Figure 6.-Map of Pahaquarry copper mine, Delaware Water Gap, Warren County, N. J.

The copper was undoubtedly discovered by reason of the green malachite stains in the outcrop. These stains occur on joint planes and do not extend more than a few feet beneath the surface in the workings visited. In places dark-colored nodules and balls of somewhat irregular form are seen in the sandstone and are found to consist chiefly of copper glance. Such nodules tend to occur in local patches. The engineer in charge, Dr. Keith, states that over 100 samples, taken at different points over the property, show that the ordinary gray sandstone carries 3 per cent copper in the form of copper glance. In the richer ore this mineral can be seen in minute specks impregnating the sandstone. In the leaner ore it can not be recognized with the naked eye, but samples of the rock when pulverized can be panned and the copper glance concentrated. The 
ore-bearing sandstone is dense and not readily permeable, and is traversed by vertical joint planes having a direction of N. $20^{\circ}$ E., or $40^{\circ}$ to the strike. The intervening red shaly members have a splintery fracture, due to rudely developed cleavage, corresponding in direction to that of the joints in the sandstone.

The copper-bearing sandstones have been traced for 3 miles along the mountain flanks, and have been proved by. workings to be cupriferous for a thickness of about 230 feet, about 10 per cent of which, or 23 feet, is red shale. The value of the deposit depends entirely on cheapness of working. The amount of low-grade material available is enormous.

The structural geology of this interesting occurrence is extremely simple, but the presence of disseminated glance in the sandstones is somewhat difficult to explain. No fossil remains have ever been found in the sandstones of this age in New Jersey, nor has any organic matter as yet been found in them.

\section{DEVELOPMENT.}

It is purposed (1905) to treat the ore by the Keith process. A large mill capable of handling 200 tons of ore daily is in process of erection, the building itself being nearly completed. In the Keith process the sandstone would be ground to a 60 -mesh powder. This material, mixed with 2 or 3 per cent of coal dust, will be charged in the top of a 40 -foot shaft furnace having numerous jets of burning gas near its top. As the powder falls through the gas it is heated and drops to the bottom of the shaft, where it is caught in a shallow V-shaped trough. It is assumed by Dr. Keith, as a result of experimental work, that the carbon and the reducing character of the gases will reduce the sulphide to the metallic form, making minute globules of native copper, which can be concentrated on Wilfley tables and smelted in appropriate furnaces. The dust from this furnace will be, it is said, gathered in a second tower of equal height, packed with stone or other loosely broken material, and kept wet by falling water. A strong exhaust draft will cause the gases from the furnace to pass up this stack, and the water is expected to eliminate all flue dust and to wash down the material from the furnace into the launders that lead to the concentrating tables.

\section{PENNSYLVANIA.}

\section{SOUTH MOUNTAIN REGION.}

Pennsylvania has many small copper deposits, but no producing copper mines. The South Mountain region has long been known to contain copper, and the finding of native copper and carbonate ores at numerous points along the slopes has led to several attempts to 
develop paying properties. Small amounts of ore have been shipped, but no regular production is recorded. As the properties are occasionally brought to the attention of investors, a few notes on the locality are worthy of record.

The South Mountain copper belt has been investigated very thoroughly by Williams and Bascom ${ }^{a}$ and mapped in detail. The belt extends for 13 miles along the mountain, 9 miles in Pennsylvania and 4. miles in Maryland. The most northerly deposit is on the old Baker farm. To the south the Bigham property, on the north side of Pine Mountain, shows outcroppings and débris of cupriferous rock. Musselman Hill, south of the property last named, shows a well-defined mass of cupriferous greenstone, and a 50-foot shaft, sunk on the summit of the hill obtained native copper from an epidote-quartz rock. Copper is also found at short intervals across different farms, the most southerly being south of the Maryland line. The Bechtel shaft of the old South Mountain Copper Co. is the best known, the shaft having been driven to a depth of 120 feet.

The geology of this South Mountain region was not unraveled until Walcott ${ }^{b}$ found Cambrian fossils in the quartzites and other rocks. This and the discovery of the igneous nature of the slates and greenstones by Williams furnished the key for the detailed work of Bascom and others. It is now known that the mountain consists of both acidic and basic rocks (aporhyolites, basalts, and fragmental forms of these rocks) overlaid by Cambrian sediments. Both sedimentary and igneous rocks are slaty, and the foliation planes of the different rocks are conformable. The foliation and bedding planes in the quartzite are easily confused and the original lamination of the rhyolites closely resembles bedding and led to their classification as sedimentary rocks. The slates are almost entirely sheared igneous rocks, and in some shear zones only 20 feet across carry gradation from porphyry to fissile slate is clearly observable. Williams ${ }^{c}$ has shown that the basic rock in which the copper occurs at the Bechtel shaft is a normal basalt. As this rock is characteristic of the Blue Ridge copper belt of Maryland and Virginia, where it forms the Catoctin schist of Keith, Williams's description is given herewith: ${ }^{d}$

These rocks [basic lavas or greenstones] have been more generally sheared into slates than the acid lavas. The chemical alteration which has gone on in them is also in general greater. Still, large masses of the basic rocks have been but iittle altered and remain quite massive. These, which are locally known as "copper rock," *** are for the most part very fine grained vesicular

a Bascom, F., and Williams, G. H., Volcanic rocks of the South Mountain in Pennsylvania and Maryland: Am. Jour. Sci., 3d ser., vol. 44, 1892, pp. 482-496. Bascom, F., Bull. U. S. Geol. Survey No. 136, 1896.

${ }^{b}$ Bull. U. S. Geol. Survey No.-134, 1896, pp. 17-18.

- Williams, G. H., Volcanic rocks of South Mountain, Pennsylvania : Am. Jour. Sc1., 3d ser., vol. 44 , p. 491 .

d Idem, pp. $490-491$. 
flows, whose original structure is still so well preserved that they may with propriety be called basalts. * * The South Mountain basalts are usually homogeneous, dark to pale green masses, which rarely show any microscopical phenocrysts and whose most constant feature is an amygdaloidal structure. These cavities vary greatly in size, shape, and abundance. They are often elongated by flow motion in the lava and are now filled with a number of secondary minerals, the most abundant of which are epidote, chlorite, quartz, and zeolites.

Williams notes that the alteration of these ancient vesicular basalts is in places surprisingly small. The ferromagnesian constituents are universally altered to epidote, chlorite, or serpentine, but the structure is perfectly preserved in its minutest detail. The ophitic structure, the form of the basaltic magnetite, olivine phenocrysts, and interstitial pyroxene are plainly visible.

According to Bascom, ${ }^{a}$ epidotization is the prevailing feature of the copper belt, and epidote is the constant accompaniment of the metal. This mineral has resulted from the interaction of plagioclase and pyroxene, as well as from the alteration of olivine to epidote, serpentine, and iron oxide. Ilmenite has also altered to leucoxene and magnetite to hematite. Bascom's observations ${ }^{b}$ show that the ore occurs in many places at the contact between greenstone and the acidic volcanic slate. The copper occurs in quartz-calcite veinlets, in fractures in epidosite, greenstone, and acidic amygdaloids, and in fissures in the massive greenstone itself.

The copper is secondary throughout the belt, occurring in seams and amygdules, where it has been deposited from solution. *** The replacement of feldspar by chlorite and epidote, and their replacement in turn by copper, characterizes the amygdaloids of South Mountain also.

Further information on the genesis of copper of this type is given in the description of the deposits of the Blue Ridge region of Virginia (pp. 93-115).

\section{NORTHERN COAL REGION.}

The occurrence of copper ores in the Catskill group of northern Pennsylvania beneath the upper coal seam of that region was known as early as 1850, and in 1854 the Towanda Copper Co. was organized to work the Carpenter mine, near New Albany, Bradford County, Pa., 12 miles from Towanda and one-half mile north of the Pennsylvania Railroad and canal. According to August Partz, ${ }^{\circ}$ the copper ores occur in a gray shale that forms part of the Devonian rocks underlying the Carboniferous mesas east of the Susquehanna coal region. The copper-bearing rock is a gray clay shale forming a bed $2 \frac{1}{2}$ to 4 feet thick and lying horizontally or dipping at a low angle

a Bascom, F., Bull. U. S. Geol. Survey No: 136, 1896. p. 85.

${ }^{\circ}$ Idem, pp. $26,27$.

- Min. Mag., vol. 3, 1854, p. 433. 
to the west. The beds are exposed at the base of a hill 100 feet high in a small ravine or branch of Towanda Creek. The exploration work of 1854 consisted of two tunnels, 20 and 30 feet in length. The seam was found to contain disseminated copper throughout its entire thickness, but the best ore was struck at the bottom of a bed ranging in thickness from 4 inches to 16 inches and averaging about a foot. The ore consisted of black oxide, both tenorite and melaconite, of green carbonate, and of copper glance. It was associated with stringers of soft red clay and abundant lignite, found as branches of trees and other forms of plant remains. The floor of the seam was a limestone conglomerate 6 inches thick, containing copper associated with fossil plant remains. The ore bed was overlain by red shale. Samples of the better grade of ore carried from 20 to 30 per cent copper; the lower-grade ore carried 3.15 per cent copper.

This and other properties near the town were visited by the writer in September, 1905. The locality is a part of the Allegheny Plateau, whose limit extend to Wilkes-Barre and Williamsport. The plateau is underlain by a series of red shales and sandstones, the Catskill formation, which is underlain by the marine grayish-green to buff-colored sandstones of the Chemung formation and is characterized by calcereous sandstones. The copper ores near. New Albany are found in the hills immediately surrounding the town in a bed of shale intercalated in a dark reddish to purplish sandstone belonging to the Chemung formation. The Carpenter mine is about $1 \frac{1}{2}$ miles from the town; the "new" workings are nearer, being only three-fourths mile to the northwest.

The Carpenter workings were driven into the nearly horizontal beds forming the walls of a ravine that lay close to the main road. Inasmuch as the workings were full of water it was impossible to estimate their extent, but inspection showed that a chamber at least 20 feet wide had been cut out along the ore seam and the roof supported with wooden props. The seam runs about 8 inches thick, reaching in places a thickness of 18 inches. It consists of a clay shale, showing films of malachite on bedding planes and small cross fractures, along which the ore makes down in places, forming little pockets in the red shale of the floor. The roof consists of a red shale bed 2 feet thick, capped by an impure red standstone. Near the point where the stream makes a little waterfall over the cliffs the ore seam rests on a leafy gray shale, which in turn is underlain by a sandstone forming the creek bed. No glance was seen, but the ore is associated with lignite, and its occurrence evidently depends on the presence of carbonaceous matter. The rocks dip $2^{\circ}$ to $3^{\circ}$ downstream.

At the "new" workings, as they are commonly called, a drift has been run from the level of the creek into the wooded hillside, open- 
ing up a seam, about 18 inches thick, of indurated dark-gray shale, showing malachite films and containing nodules of soft black material, which appear to be glance mixed with carbonaceous matter. A small amount of ore is reported to have been shipped to New York in 1903 and to have yielded $2 \frac{1}{2}$ per cent copper and a little silver. The ore seam is capped by red sandy shale, forming the overlying hill. The dip is about $2^{\circ}$ or $3^{\circ}$ into the hill, and the adit, which is 30 feet long, is filled with water and is not workable. The workings are about one-eighth mile below the dam which supplies the town with water.

The hill immediately east of New Albany, overlooking the railroad station, rises to a height of about 250 feet above the railroad. This hill is composed of gray shale capped by red sandstones, and near its summit is a belt of red sandstone which weathers in a persistent cliff running around the slope. In this cliff there is an irregular bed of shale ranging in thickness from a few inches to a foot or two. Parts of this bed are impregnated with malachite.

\section{EAST-CENTRAI REGION.}

Similar ores occur in Monroe and Pike Counties, Pa., the copperbearing strata stretching for several miles across the country. The ore is scattered in little patches through a bed 1 to 2 feet thick, which is underlain by red shale and overlain by blue flagstone. According to Mr. Josiah Bond, ${ }^{a}$ there is a vast quantity of the material, and his samples, taken with some pains from the surface and disregarding the ore bunches, ran 0.6 per cent copper, 1 ounce silver, and a trace of gold. The ore is most abundant in cavities and segregations, some of which carry small amounts of 8 to 10 per cent ore. These localities have not been visited by the writer.

Above the seam sampled there are several seams at different horizons, in which little ore occurs. According to Mr. Bond, the copper occurs in the Catskill formation.

The Perkiomen mine, in Montgomery County, was formerly worked. for copper, the ore occurring in sandstone near a gneiss contact.

\section{COPPER MINED WITH OTHER METALS.}

The Gap mine, Lancaster County, was originally opened for copper, but was not.profitably operated until the nickeliferous contents of the ore were recognized and it was worked for that metal. The property has been closed down in recent years.

Copper is found in the iron-ore deposits along the edges of the Triassic belt and its trap intrusions, usually in the limestone and green shale, as at Cornwall, Dillsburg. (York County), Boyertown (Berks County), and at Fritz Island and Wheatfield, near Reading. 
The Cornwall iron mine, near Reading, has produced about 300,000 pounds of copper from ores consisting of chalcopyrite and magnetite and the decomposition products. The iron ore bodies are large and occur above a great diabase dike in a fault separating Cambro-Ordovician shale and limestones from Triassic sandstones. The chalcopyrite occurs in irregular nodules and veinlets in the calcareous shale (Cambrian).

In all these deposits the copper is supposed to come from the alteration of the trap. It is suggested by Spencer that the ores are really contact deposits, due to emanations from the dike.

\section{MARYLAND.}

There are three copper belts in Maryland which were of considerable importance before the Lake Superior mines were exploited. The first belt extends from New London, in Frederick County, northeastward to Union Bridge. The second extends from Sykesville through Carroll County to and beyond Finksburg. The third is in the Bare Hills, north of Baltimore.

\section{WESTERN BELT.}

Description.-The western or New London-Libertytown copper belt is still the scene of intermittent mining operations. The copper occurs in or alongside of masses of dolomitic limestone and marble included in micaceous schist. According to the geological map published by the State survey and a detailed survey of the Frederick quadrangle by Keith this belt consists of several narrow but long bands of greenstone, Catoctin schist) - amygdaloidal, extrusive, basaltic rocks which have been folded in the gray and black phyllitic schists. In most of the area from New London northeastward belts of marble in long, narrow, closely compressed folds with very steep dips, in places saddle-shaped and in others canoe-shaped, lie east of the greenstone. The copper ores appear to be confined to these marbles and to the schists alongside of them, occurring either along the contact or in the fractured rock itself, as, for example, in the recent workings of the Liberty mine. This association was recognized by Persifor Frazer in his examination of the New Windsor deposit. Before that the slaty or schistose greenstone had been overlooked and its significance not recognized.

- The meager facts cited would not warran $₫$ any generalizations were it not for the frequent presence of copper in the greenstone belt from Pennsylvania to the Carolinas. It is believed that this rock furnished the copper for the solutions and that the limestone and its graphitic matter supplied the precipitant for the copper. 
Mines.-The New London, Liberty, Dolly Hyde, and Union mines were formerly extensively worked.

The New London mine is at New London, Frederick County, 10 miles east of Frederick and 4 miles from Monrovia station on the Baltimore \& Ohio Railroad. The mine workings are in the southwest corner of the first crossroads west of New London. The surface exposures show greenstone schist on the east, and normal dark-gray or black phyllite schist on the west. The marble is intricately and minutely plicated, with consequent slipping along the sides of the plications and the infiltration of ore-carrying solutions along the crushed masses and cross fractures.

The deposit has been stoped where richest, the ore shoots worked lying on each side of the incline and being about 80 feet in length. The ore is supposed to average 3 per cent copper.

The Dolly Hyde mine has been idle so many years and the ground about it has been so thoroughly tilled that no observations of value can be made. The ores consist of bornite in marble and occur in volcanic rocks altered to gneisses and schists.

The Liberty mine was visited in company with Prof. E. B. Mathews. It is the largest and has been the most productive copper mine of Maryland, and the great dump heaps attest the extent of the underground workings. . In 1905 these were filled with water, and the ore mined came from a new opening to the east.

The property lies on the flat summit of the Linganore Hills, about one-half mile west of the main turnpike between Libertytown and Union Bridge. The deposit occurs in a narrow limestone band, possibly one of those seen in the limits of the town of Liberty, west of but near a greenstone belt. The ore body seen in the new workings is composed of white and pink marble, which in places is broken, with the cracks and spaces filled by bornite, glance, and less commonly by chalcopyrite. The ore is easily mined and cheaply crushed and concentrated, as the gangue is either marble or coarsely crystalline calcite. The upper surface of the marble is deeply pitted and irregularly corroded with deposits of black oxide of manganese upon it.

About 7 miles northeast of Liberty a similar deposit has been described by Persifor Frazer. ${ }^{a}$ The ore occurs along the contact between the "hydromica" schists and narrow troughs of marbleized dolomitic limestone. It consists of 6 to 18 inches of rich copper sulphides and iron oxide and of an impregnation of the limestone for 12 to 15 feet from this contact. The dip is steep, $60^{\circ}$ to $72^{\circ}$, and the strike is about N. $20^{\circ}$ to $30^{\circ}$ E. Some of the openings showed zinc blende and galena. An analysis of the impregnated. 
limestone ore gave 4.55 alumina, $0.51 \mathrm{Fe}_{2} \mathrm{O}_{3}, 23.34$ lime, 8.94 magnesia, 0.87 silica, and 12.90 copper, with 44.44 carbon dioxide.

\section{MIDDLE BELT.}

A copper-bearing fissure vein that has been worked at various localities is distinctly traceable across Carroll County from a point south of Patapsco River at Sykesville to .Finksburg, in Carroll County, and less clearly to Bluemont, south of Whitehall, on the Northern Central Railroad, and to Cooptown, in Harford County. The Springfield mine at Sykesville, the Mineral Hill mine, and the Patapsco mine near Finksburg are all on this vein, and have been valuable producers in their day.

The Sykesville mine was opened by James W. Tyson as a magnetite mine in 1849 , and the product smelted at his Elba furnace nearby. With increasing depth the magnetite gave way to chalcopyrite. It yielded between 500 and 1,700 tons a year until abandoned in 1868.

The Mineral Hill mine, half-way between Sykesville and Finksburg, opened in revolutionary time, was reopened by Tyson in 1849 and worked intermittently until 1890 . The dip is $50^{\circ}$ and the vein is developed for 370 feet on the dip and by adits (tunnels). The ore is chalcopyrite, with bornite, glance, and some magnetite.

The Patapsco mine at Finksburg, like the others, has long been abandoned. The vein is a line of dislocation and faulting, as shown by the greatly contorted and crushed material seen on the dumps. The gangue is steatite, in many places containing siderite (ironspar) rhombs, with accessory actinolite, quartz, and epidote, and quartzose slate in places. The vein has yielded various rare minerals, particularly those of cobalt-carrolite, remingtonite, siegenite, and locally native gold in magnetite. ${ }^{a}$

\section{EASTERN BELT.}

The Bare Hills vein carries chalcopyrite, bornite, magnetite, and pyrite, mixed with amphibole-anthophyllite in broad brown blades, together with hornblende and chlorite. The vein cuts hornblende gneiss, and is exposed about a mile south of Mount Washington, where it has been developed by an incline shaft, following down the dip of $45^{\circ}$ to a depth of 800 feet.

The Bare Hills copper mine is situated on the summit of a ridge immediately west of Jones Falls, at Mount Washington, Md. The property was opened in 1866 and worked intermittently for many years, yielding a large output of ore, which was shipped to the Baltimore Copper Works. It was not in operation for 15 years between

"Williams, G. H., Geology of Baltimore and vicinity, in Guide to Baltimore, 1S92, pp. $122-123$. 
1886 and 1900. At the last-named date a stock company was formed to reopen the property, new machinery was installed, and the mine was unwatered. No new development, however, was begun and the property was sold under a deed of trust. In 1905 the mine was in the possession of Mr. Herbert Brown, who was preparing to unwater and work the property.

The mine is equipped with all necessary surface buildings, boilers, air compressor, an old-fashioned hoisting engine, and a Cornish pump.

The main shaft is 832 feet deep, and drifts have been run at frequent intervals and the intervening ore practically stoped out. Two other shafts afford ventilation but are not accessible. When the property was visited the water stood within 100 feet of the collar of the shaft, and the 90 -foot level was the only one accessible.

According to Doctor Lehmann, of Baltimore, this mine was operated almost continuously from 1866 to 1887 , the entire output going to the Baltimore Copper Works, the sampling and assaying being under Doctor Lehmann's supervision. The records of both his office and of the copper company were destroyed by the great Baltimore fire, but the old samples, labels, and memoranda at hand enable him to give the following rough estimate of the total output.

Prior to 1866 the yearly shipments varied between 2,000 and 2,500 tons of 15 to 20 per cent ore. From 1866 to 1876 the annual output was from 800 to 1,200 tons of "cobbed" ore, averaging 18 per cent copper, with 1,000 to 1,500 tons of "hutched" ore or concentrates. From 1866 to 1887 the shipments gradually lessened, being about 50 tons a month of 18 per cent cobbed ore from 1883 to 1886. Taking the average of these figures the total output from 1864 to 1887 is about 32,500 tons of 18 per cent material. At 15 cents a pound for copper this represents a gross valuation of $\$ 54$ per ton, or a total value of $\$ 1,755,000$. According to the Tenth Census, ${ }^{a}$ the mine in 1880 yielded 17 tons of concentrates, from which 1,275 pounds copper were produced.

\section{VIRGINIA. $b$}

\section{DISTRIBUTION OF THE ORES.}

Copper ores are widely distributed throughout the State of Virginia, though there are but few producing mines. The ores are confined to the crystalline rocks of the Piedmont and Blue Ridge areas and to the red Triassic beds which form separate, disconnected, smaller areas over the Piedmont province.

a Vol, 15, p. 798 .

- These notes on the Virginia deposits, combined with others made by Prof. T. L. Watson, are in large part incorporated in a report written for the Virginia Geological Survey, in which the petrographic notes are furnished by Professor Watson. 
The known copper districts of the State are grouped geographically below :

1. The Piedmont region:

(a) Virgilina district (includes Halifax County, Va., and Person and Granville counties, N. C.).

(b) Albemarle County (Southwest Mountain).

(c) Keysville, Charlotte County, and Dillwyn, Buckingham County ("Eastern belt").

(d) Triassic area (Loudoun, Culpeper, Orange, and Amherst counties).

2. Blue Ridge region:

Districts from near Front Royal southward, embracing parts of Warren, Iappahannock, Madison, Page, and Green Counties.

3. Southwest Virginia region:

Floyd-Carroll-Grayson County plateau. (Gossan leads.)

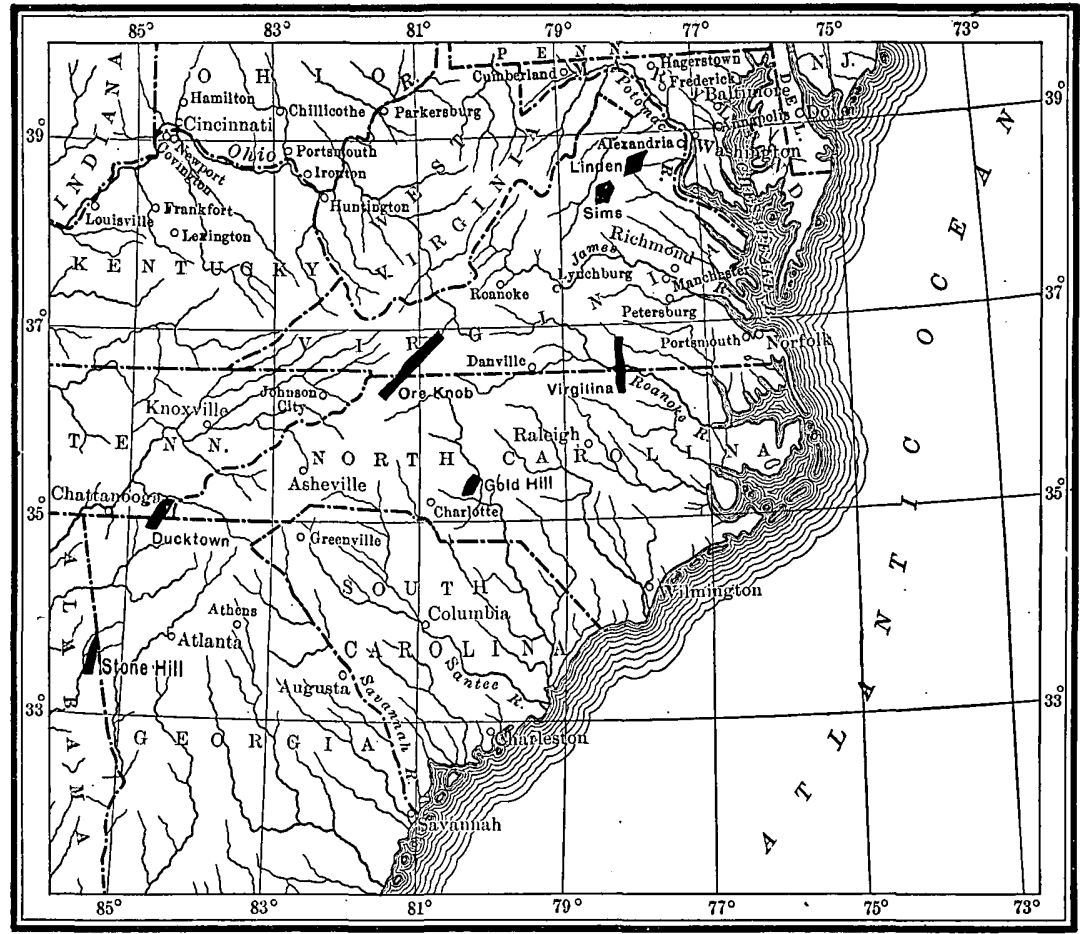

Figure 7.-Index map showing copper deposits of Virginia and other Southern Appalachian States.

The copper ores are confined to the crystalline rocks, either the slates and schists or the massive igneous rocks of the Piedmont and Blue Ridge provinces, and to the red shale sandstone series of the Triassic areas. In the Virgilina district the ores occur in quartz fissure veins which intersect masses of altered andesite (metaandesite) of pre-Cambrian age. ${ }^{a}$ In the Blue Ridge region the ores are dis-

${ }^{a}$ Weed, W. H., Trans. Am. Inst. Min. Eng. 1901, vol. 30, p. 454 ; Watson, T. L., Bull. Geol. Soc. America, vol. 13, 1902, pp. 353-376. 
seminated through and segregated in basaltic flows (fig. 8) of preCambrian age, designated by Keith ${ }^{a}$ the Catoctin schist. In the Floyd-Carroll-Grayson County plateau the so-called "gossan leads" are apparently mineralized faulted zones in schists of doubtful age,

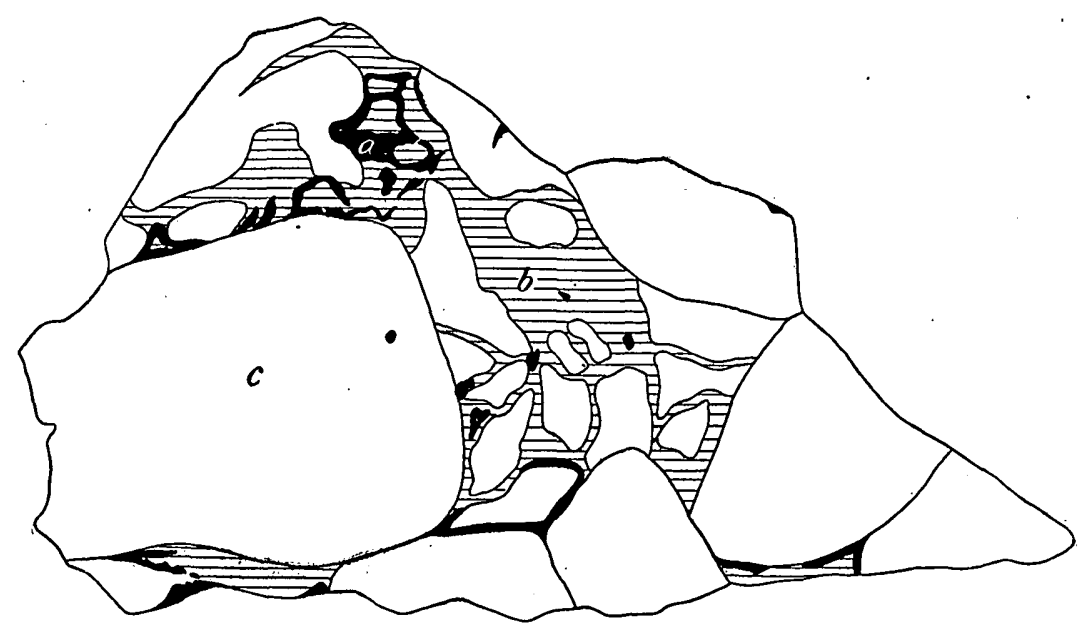

Figdre 8.-Brecciated epidotized basalt, showing ore and quartz. Stonyman Mountain. $a$, Native copper; $b$, quartz; $c$, epidote rock.

probably pre-Cambrian in part and in part altered igneous masses of the basic type. In the London-Culpeper County region the deposits are sparsely desseminated copper compounds in Triassic red sandstones and shales.

\section{PIEDIMONT REGION.}

VIRGILINA DISTRICT.

LOCATION.

The Virgilina district, in Halifax County, Va., and Granville and Person counties, N. C., takes its name from the town of Virgilina, situated on the line between the two States. The Danville division of the Southern Railway passes through the town, which is 47 miles east of Danville. The Norfolk \& Western and the Richmond \& Danville roads lie not far to the north and west.

The topography is hilly or undulating, like much of the Piedmont plateau. The mines thus far developed all lie upon a low ridge, a flat-topped elevation 100 to 250 feet above the neighboring stream valleys, and from one-half mile to 2 miles or more in width. This ridge is cut by numerous cross drainages and stream hollows, and it is only at the northern end near the Hyco River, where it is called High Hill, that its elevation above the surrounding country is apparent.

$a$ Keith, Arthur, Fourteenth Ann. Rept. U. S. Geol. Survey, 1895, pp. 285-295. 
The ridge is traced northward to the Dan River valley, in Virginia, approximately 10 miles north of the State line. In North Carolina it is estimated by Hanna ${ }^{a}$ to extend south for about 30 miles, reaching nearly to Durham. Prospecting is confined, however, to an approximate north-south distance of 18 miles along the ridge and to an average cross distance of from 2 to 3 miles. Although of no conspicuous height, the ridge forms a somewhat prominent feature in the landscape.

Water is abundant in winter but scarce in summer, when most of the small creeks run dry. Hyco River is the nearest available source.

Much of the district is timbered with hardwood and locally with pine, but the timber has been largely culled and it is only in small tracts that it is found of sufficient size to serve for mining purposes. The land is owned in large tracts, usually of several hundred acres, the title to which generally carries the mineral ownership.

\section{HISTORY.}

The district has been more or less prospected for the last forty or fifty years, as shown by the pits and shafts found for 8 miles north and an equal distance south of the State line. ${ }^{b}$ The Gillis mine was opened in $1856^{\circ}$ and a fine body of glance ore exposed. The district remained practically unexplored, however, until 1897, though considerable money was spent there in 1886-87, when the Blue Wing mine was opened and 500 tons of ore were extracted. Some prospecting was also done on the Yancey mine, but unfavorable reports were made by experts and the property remained idle until 1897. In that year the district was again the scene of active operations, and 225 carloads of ore were taken out and shipped to the Orford Copper Company.

From 1898 to 1904 active prospecting was carried on, and several hundred thousand dollars were spent in opening up the various veins. The most extensive work was done on the property of the Virginia Copper Company, Ltd., at the north end of the belt immediately south of Hyco River. The workings on this vein aggregate 2,306 feet of levels, and one shaft is 339 feet deep. At the south end of the belt the Person Consolidated Copper Company has extensive workings and a shaft 300 feet deep. Both companies possess concentrating mills and have shipped both high-grade ores and concentrates. While these two properties were being developed and equipped with modern machinery, the other mines of the belt were

a Ores of North Carolina, Raleigh, 1888, p. 215.

${ }^{b}$ Phillips, W. B., Eng. and Min. Jour., Apr. 1, 1899 ; also, Am. Manufacturer, Mar. $17,1899$.

- Emmons, E., Geology of midland counties of North Carolina: Geol. Survey. North Caroliná, 1856 , p. 344. 
also deepened and the workings carried forward. The two mines mentioned, however, are the only ones having large plants. In 1905 the Person Consolidated was the only producing company. The Holloway mine, formerly the largest mine in the district, was reopened in the summer of 1905 . The idleness of most of the properties is attributed to several causes, but it is reasonably laid to the low-grade ( 2 per cent) highly siliceous character of the ore and the impossibility of smelting it at a profit on the spot, owing to the lack of fluxes and of cheap fuel. Overcapitalization may also be responsible for the present depression, and the expenditures so far made have been directed rather toward making an attractive showing than toward conservative development.

ROCKS OF THE DISTRICT.

GENERAT. FEATURES.

The country rock is schist, in few places massive enough to be called gneiss. Natural outcrops are rare, few are more than 2 or 3 feet high, and those few are sharp and narrow reefs, persistent for short distances only. The covering of loose, decayed surface rock, and soil is, however, very thin, and moderately firm rock lies at slight depths beneath the surface.

The numerous shafts sunk over the greater'part of the belt to depths of 40 to 300 feet afford excellent opportunity for exceptional collections of the rocks and ores.

At the mine openings some oxidation of the vein constituents is indicated to the entire depth of the workings, 100 to 300 feet. This is shown in the case of the sulphide ores, which in several places are slightly changed by the percolating carbonated waters to the green copper carbonate (malachite) found slightly staining the vein material and the unaltered ores. The rocks at these depths are of the characteristic green color, and the thin sections indicate the same amounts of chlorite and epidote as those from the shallow depths. Specimens of the rocks collected at different depths are macroscopically and microscopically indistinguishable.

The rocks are shown by the microscope (p. 71) to be of igneous origin, though, with few exceptions, their nature is not apparent in the field. They are prevailingly finely laminated and schistose in structure, having the general characteristic features of a soft green to purple schist, in this report called a greenstone schist. Observations at a number of good exposures show the prevailing strike of the schistosity to be N. $10^{\circ}$ to $20^{\circ} \mathrm{E}$. and the dip $70^{\circ}$ to $80^{\circ} \mathrm{E}$.

The condition of these rocks results primarily from metamorphism while the rocks were deeply buried. Subsequently, when the rocks were brought near the surface, they were further changed by weather- 
ing. The mineral products resulting from the alteration are very apparent. Epidotization and chloritization are manifested on a considerable scale.

The schists are cut in several places by diabase dikes of later geologic age. One of these dikes, 12 feet wide, is exposed in the Blue Wing mine at the 100 -foot level, where it is observed to cut across the schistosity of the rocks. These dikes are described in the reports of the North Carolina geological survey as being numerous in parts of Granville and Person counties.

According to Watson ${ }^{a}$ the rocks show a pronounced schistose structure; in only a few places are massive eruptives found in the field. In degree the schistosity ranges from the banding. of a gneiss to the typical foliation of micaceous schists. The very finely banded structure is more characteristic of the purple-colored rocks. The color of the rocks ranges from some shade of medium to dark green (the prevailing color) to a slate purple.

\section{Professor Watson continues:}

The rocks are aphanitic in texture, displaying at times a distinct porphyritic structure in the massive phases, which becomes more apparent under the microscope. The massive phases of the rock are indicated at several places within a few miles to the north and south of the town of Virgilina. With one exception this type is prevailingly dark in color, showing on close examination a mingling of green and purplish shades, with the greenish tint so predominant that the rock appears dark green on first glance. Both the characteristic chlorite and epidote shades of green are contrasted at times in the same specimen. On a freshly broken surface the fracture is conchoidal to subconchoidal, with a more or less waxy luster.

Approximately half a mile south of Virgilina a shallow opening (Cornfield) is made, showing the massive rock in its least-altered condition [analysis 1 , p. 73]. The rock is porpbyritic in texture, and the color is a medium darkpurplish shade which contrasts with the surrounding more-altered green schistose rock.

Epidote of the usual pistachio-green color enters largely in places into the composition of the rocks, and it is mixed locally in considerable proportion with white quartz as a vein mineral. The schistose greenstone is easily scratched with the knife, and suggests approximately the same degree of hardness as that of ordinary clay slate.

At the Copper World mine, $6 \frac{1}{2}$ miles south of Virgilina, in the Carolina portion of the belt, a partially loose-textured, fine-grained, purple rock is mixed with the surrounding green schists. The material bears every resemblance to a tuff, and is streaked in places by the characteristic actinolite shade of green due to alteration, and contains inclosures of a dark-colored massive material, usually of small but varying dimensions and partially rounded in outline. The fragmental or clistic nature of the mass is plainly visible. The microscope confirms the clastic' nature of this rock and shows that it is composed of fragments of igneous rocks of the same character and composition as the igneous rocks of the district. Microscopic study also indicates the presence of similar clastic material at a number of other points in the district.

$a$ Watson, T. L., Copper-bearing rocks of the Virgilina copper district: Bull. Geol. Soc. America, vol. 13, 1902, pp. 353-376. 
MICROSCOPIC CHARACTER.

\section{Professor Watson has carefully examined the rocks under the microscope. He says :}

The rocks vary in texture from dense aphanitic to medium fine-grained with the porphyritic structure shown usually in the massive types. The original minerals are entirely altered to secondary minerals in many of the sections, but with few exceptions some trace of the original outline of the feldspar constituent is shown and more or less of the original rock texture preserved. While this is true for the feldspar constituent, the original bisilicate constituent is completely altered in every slide studied, without any indication as to what the original mineral was. Considering the age and composition of the rocks it seems remarkable that any of the original minerals or structures should be preserved at present. When shown, the texture varies from a partial microophitic to microlitic in the nonporphyritic types, with the same variation and composition of the groundmass in the porphyritic rocks denoted.

The constituents present are plagioclase, bluish to light-green amphibole, chlorite, epidote, zoisite, calcite, iron oxide (partly magnetite), quartz, and apatite. Of these only the feldspar, a part of the iron oxide (magnetite), and apatite are original. Both chlorite and epidote, intimately associated with more or less hornblende, are abundantly developed in most of the sections, sometimes one, sometimes the other predominating; but the two are at all times intimately connected.

In the porphyritic and nonporphyritic types the feldspar is present as lathshaped crystals, showing the broad twinning lamelle of the albite type. Twinning after the Carlsbad law was observed in several instances. In the groundmass of the porphyritic rocks and in the fine-textured nonporphyritic types the feldspars are microlitic, with the boundaries less sharp and well defined than for the lath-shaped feldspars, and the twinning is not at all or only slightly indicated. Sometimes the feldspar grouping is suggestive of the sheaflike arrangement described by Clements ${ }^{a}$ in similar volcanic rocks of the Hemlock formation of Lake Superior. Poikilitic texture is well developed in many of the larger feldspar laths.

Feldspar is the only porphyriticallỹ developed minerai, and it consists of fairly large stout laths of broadly striated plagioclase, with maximum extinction angles measured on the twinning planes of $14^{\circ}$ to $20^{\circ}$, which would apparently indicate an acid plagioclase, probable near oligoclase.

The feldspars of both the groundmass and phenocrysts are frequently fractured and mashed, showing the effects of pressure, which is seen to best advantage in the schistose rocks.

Not a trace of original hornblende was positively identified in any of the sections. Amphibole is fairly abundant in most of the slides as a secondary product, and as such it is usually light-green to slight bluish-green in color and as fibrous and frayed-out masses. A more common occurrence, perhaps, is as a felt of actinolite needles admixed with the other constituents, particularly chlorite, epidote, and iron oxide. The needles are very long and slender and are frequently much curved and bent. The pleochroism of the actinolite is usually quite strong.

No trace of either augite or olivine was indicated in any of the slides. On account of the greatly altered condition of the rocks, it would not be safe to state that they were not present as original constituents.

a Mon. U. S. Geol. Survey, vol. 36, 1899, p. 99. 
Chlorite is a constant and abundant constituent of the rocks, but is variable in amount, and presents the usual occurrence, for such rocks. A striking feature is the intimately associated grains and plates of epidote distributed through the chloritic mass in a manner to indicate the simultaneous development of the two minerals, a characteristic occurrence in some of the Lake Superior greenstones described by Williams. ${ }^{a}$ Clements ${ }^{b}$ bas shown that in some of the basic volcanics of the Hemlock formation the great abundance of chlorite in some sections is more than could result. from the alteration of that amount of the original bisilicate present, and he points out that it is derived in part from the altered glassy base. This explanation is likely applicable to some of the sections of the Virgilina rocks, since the amount of chlorite is in excess of the original bisilicate, and is probably a derived product in part from an altered glassy base.

Epidote in the form of small and large irregular grains and plates is abundantly present, closely associated with chlorite and amphibole. It varies in color from deep yellow to nearly colorless grains, with high single and double refraction, and showing strong pleochroism in the colored individuals. The somewhat idiomorphic plates show the $M(001)$ and $T(100)$ cleavages in their usual development.

Zoisite, when identified, was closely intergrown with the epidote, forming an epidote-zoisite aggregate, the individuals of which are differentiated by their contrasted double refraction.

Iron oxide is extremely abundant in portions of some of the sections and to some degree in all. It is not all magnetite, as indicated by the red color of much of it. It is separated from the other constituents of the powdered rock by means of the magnet. It occurs as minute grains and crystals, and is in part primary and in part secondary. It is so abundant in some sections as to entirely mask some of the more important constituents. Its secondary nature is frequently shown in its peripheral position surrounding the iron-bearing constituent from which it was derived.

The remaining minerals occurring in the rocks present no noteworthy features.

In the thin sections of the purple-colored slaty rocks of the Copper World [mine], the [Person Consolidated] Durgy and Yancey mines, and the "slate vein " in the Carolina portion of the belt, and probably the fissile" greenstone from the Halifax copper mine in Virginia, there is strong evidence for regarding the rocks as clastic volcanics. The evidence is less plain in some sections than in others, on account of extreme alteration having destroyed nearly all trace of the rock structure. When the texture is not entirely destroyed the microscope shows a clastic composed of igneous fragments similar in all respects to the true igneous rocks of the district.

The microscopic study entirely fails to indicate what the original characterizing bisilicate component was in these rocks-whether augite or hornblende or both, with possible biotite and olivine. We are in doubt, therefore, as to whether the rocks were originally augite or hornblende andesites.

CHEMICAL COMPOSITION.

Professor Watson has also made a chemical study of the rocks. Speaking of this, he says:

Six analyses of the Virgilina greenstones, four complete (analyses 1-5 inclusive) and two partial ( 6 and 7 ), were made by the writer in the chemical

a Bull. U. S. Geol. Survey No. 62,1890 , pp. 56 et seq.

- Mon. U. S. Geol Survey, vol. 36, 1899, p. 101. 
laboratory of Denison University. These are compared with analyses of socalled greenstones (Catoctin schist) of the Catoctin belt of northern Virginia (analysis $\$$ ). ***

Analyses of rocles from Virgilina district, Virginia.

\begin{tabular}{|c|c|c|c|c|c|c|c|c|}
\hline & 1 & 2. & 3. & 4. & 5. & 6. & 7. & 8. \\
\hline \multirow[t]{2}{*}{ 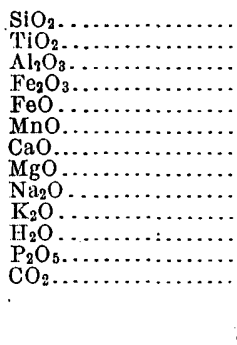 } & $\begin{array}{r}64.12 \\
\text { Trace. } \\
16.32 \\
6.72 \\
1.38 \\
.64 \\
3.49 \\
.33 \\
6.22 \\
.53 \\
.34 \\
\text { Indet. } \\
\text { None. }\end{array}$ & $\begin{array}{r}62.32 \\
.06 \\
15.79 \\
3.57 \\
4.61 \\
.35 \\
3.65 \\
2.53 \\
4.51 \\
.76^{-} \\
1.89 \\
\text { Undet. } \\
\text { None. }\end{array}$ & $\begin{array}{r}63.22 \\
.03 \\
16.05 \\
5.15 \\
2.49 \\
.49 \\
3.57 \\
1.43 \\
5.37 \\
.64 \\
1.11 \\
\text { Undet. } \\
\text { None. }\end{array}$ & $\begin{array}{r}51.34 \\
.38 \\
20.07 \\
7.03 \\
4.03 \\
.38 \\
2.83 \\
4.18 \\
1.83 \\
5.53 \\
2.90 \\
\text { Undet. } \\
\text { None. }\end{array}$ & $\begin{array}{r}48.20 \\
.24 \\
22.10 \\
7.61 \\
3.95 \\
.35 \\
8.86 \\
.86 \\
4.90 \\
1.16 \\
2.31 \\
\text { Undet. } \\
\text { None. }\end{array}$ & $\begin{array}{r}46.45 \\
\text { Trace. } \\
13.79 \\
7.60 \\
6.41 \\
\text { Trace. } \\
10.13 \\
9.81 \\
\text { Undet. } \\
2.66 \\
\text { Undet. } \\
2.27 \\
\end{array}$ & $\begin{array}{r}49.51 \\
.57 \\
22.42 \\
10.03 \\
2.42 \\
.42 \\
7.68 \\
2.81 \\
\text { Undet. } \\
3.41 \\
\text { Undet. } \\
.90 \\
\end{array}$ & $\begin{array}{r}51.08 \\
2.67 \\
11.37 \\
11.17 \\
5.64 \\
.22 \\
5.20 \\
3.96 \\
5.54 \\
1.50 \\
1.50 \\
\ldots . .39 \\
\end{array}$ \\
\hline & 100.09 & 100.04 & 99.55 & 100.50 & 100.54 & & & 100.24 \\
\hline
\end{tabular}

1. Andesite, dark-purplish gray, massive, and slightly porphyritic in texture, 0.5 mile south of Virgilina; Granville County, N. C.; Cornfield opening. Analysis by Thomas L. Watson.

2. Dark, massive greenstone; Overby opening. Analysis by Thomas L. Watson.

3. Average of 1 and 2 .

4. Iight greenstone schist, Blue Wing mine, 3 miles south of Virgilina, Granville County, N.C. Analysis by Thornas L. Watson.

5. Light greenstone schist, Fourth of July mine, 2,5 miles south of Virgilina, Granville County, N. C. Analysis by Thomas L. Watson.

6. Light greenstone schist, Anaconda mine, 1,5 miles south of Virgilina, Halifax County, Va.'Analysis by Thomas L. Watson.

7. Partially decayed greenstone schist from same locality as 6 . Analysis by Thomas L. Watson.

8. Andesite, orendase, subrang 4 (dosodic), 3.5 miles east of Front Royal, Va. Analysis by George Steiger, Bulletin U. S. Geol. Survey No. 186, 1900, p. 51; described by Keith, Fourteenth Ann. Rept. U. S. Geol. Survey, pt. 2, 1894, p. 305.

A cursory examination of the analyses is sufficient to indicate the andesitic character of the rocks. with an advanced stage of alteration shown in $4,5,6$, and 7 . Furthermore, the ratio of the $\mathrm{SiO}_{2}$ to the base-forming elements in 1 and 2 , the least-altered material, suggests an intermediate rather than an acid or basic andesite. The prevailingly low $\mathrm{SiO}_{2}$ in the remaining analyses $(4,5,6$, and 7 ) is explained on the basis of advanced aiteration, since the rocks yielding these results were the most altered and were highly schistose in structure. Other apparent irregularities in the analyses are likewise explained on the same basis, since the greatest irregularities are indicated in the analysis of the mostaltered specimens. To what extent the ore-bearing solutions bave aided in the alteration it is not possible to say, but that the change has resulted in part from such action is doubtless shown in the metalliferous veins of the district.

When 1., 2, and 3, analyses of the least-altered rock, are compared with analyses of recognized andesites occurring elsewhere, no marked differences in the essential constituents are shown.

Higher $\mathrm{SiO}_{2}$ and $\mathrm{Al}_{2} \mathrm{O}_{3}$ and lower $\mathrm{Fe}_{2} \mathrm{O}_{3}, \mathrm{CaO}$, and $\mathrm{MgO}$ in the Virgilina rocks than for the similar rocks in the Catoctin belt are noted: $\mathrm{Na}_{2} \mathrm{O}$ is approximately the same for the two rocks, with increased $\mathrm{K}_{2} \mathrm{O}$ shown in the Catoctin andesite. The Catoctin andesite is characterized by very high iron oxide and correspondingly low $\mathrm{SiO}_{2}$, and clearly represents the basic type of andesite, which readily accounts for the apparent variations shown in the comparison with the Virgilina rock. 
So far, then, as chemical analyses are trustworthy, the percentage ratios of the various constituents in the Virginia-North Carolina rocks, as indicated in 1 and 2, and their average 3, are those of andesite. Passing, then, from the least to the most altered phases of the rocks, the change is observed to consist largely in the increase in the amount of chlorite, as clearly manifested by the assumption of water (bydration), and in the increased $\mathrm{Al}_{2} \mathrm{O}_{3}, \mathrm{FeO}$; and MgO. A similar change in the rocks of the greenstone area of Michigan has been emphasized by Williams. ${ }^{a}$

A second and no less important change in the Virginia-North Carolina rocks is the increased amount of epidote in the much-altered phases of the rocks, a fact indicated microscopically as well as in the field, and further confirmed chemically in the greatly increased amounts of $\mathrm{CaO}$ in the analyses of the altered over those of the fresher rocks.

Attention is finally directed to the alkalies' ratio in these rocks, in which it is observed that $\mathrm{K}_{2} \mathrm{O}$ is reduced to practically a minimum, while the $\mathrm{Na}_{2} \mathrm{O}$ is proportionately increased. The constant presence of $\mathrm{TiO}_{2}$ and $\mathrm{MnO}$ in the analyses is a noteworthy feature.

The evidence here adduced from the descriptions of the rocks of the several areas indicates the striking fact that the present altered rock, greenstone, is remarkably similar for the several districts, but when, through chemical and microscopic means it is traced to the original rock, distinct differentiation, such as distinguishes the various basic igneous types from each other, is shown. Moreover, not only is this striking similarity indicated in the altered rock in each instance, but the processes involved in producing the alteration have been uniformly alike. The alteration has been one of structural and chemical metamorphism, resulting in the formation of abundant chlorate and epidote and smaller amounts of other secondary minerals and the accompanying secondary schistose structure.

AGE RELATIONS.

Concerning the age relations of the rocks, Professor Watson speaks as follows:

Excepting the northernmost extension of the Juratrias to the south and southeast in the vicinity of Oxford, Granville County, N. C., no known clastics of definite age are found close to the area. Dikes of Mesozoic diabase are reported to be rather numerous in parts of Granville County, and in several instances are observed cutting the rocks of this area. * * *

The occurrence of similar ancient voicanic rocks in the adjoining counties to the southeast of the Virgilina area, described by Williams ${ }^{b}$ and others ${ }^{c}$ as closely resembling those of the South Mountain area, are grouped as preCambrian in age, and can be most likely correlated with the rocks of the Virgilina district.

The rocks of this district are shown to be quite similar in many respects to the volcanics farther north in Virginia and Maryland of the Catoctin belt and of. South Mountain, a continuation of the Catoctin belt in Pennsylvania. Keith $d$

a Williams, G. H., Bull. U. S. Geol. Survey No. 62, 1890, pp. 192-217.

$b$ Williams, G. H., Jour. Geology, 1894, vol. 2, pp. 1-31.

c Nitze, H. B. C., and Hanna, G. B., Gold deposits of North Carolina : Bull. Geol. Survey North Carolina No. 3, 1896, pp. 37-43. Nitze, H. B. C., and Wilkens, H. A. J., Gold mining in North Carolina and adjacent southern Appalachian regions: Bull. Geol. Survey North Carolina No. 10, 1897, pp. 15, 16.

$d$ Keith, Arthur, Geology of the Catoctin belt: Fourteenth Ann. Rept. U. S. Geol. Survey, pt. 2, 1894, p. 319, and map, Pl. XXII, opposite p. 308. 
has shown the rocks of the Catoctin belt to be pre-Cambrian-Algonkian-in age. Likewise Williams ${ }^{a}$ and Bascom $^{b}$ have shown the series of both acid and basic volcanics of South Mountain in Pennsylvania to be of the same age-Algonkian.

The rocks of the Virgilina district are, with few exceptions, shown to be highly schistose in structure, which is a secondary structure and indicates that the area has been subjected to long-continued dynamo-metamorphism. In view of these facts and in the absence of contradictory field evidence, the rocks are placed as pre-Cambrian in age. This is in accord with the work of Kerr and Holmes, who agree in assigning the rocks of this area to the Huronian (Algonkian), ${ }^{c}$ and with that of Keith, ${ }^{d}$ Williams, $^{a}$ and Bascom ${ }^{b}$ for somewhat similar volcanics occurring to the north in Virginia, Maryland, and Pennsylvania.

It further harmonizes with the work of Williams ${ }^{a}$ and Nitze ${ }^{e}$ in the adjoining counties to the southwest of the Virgilina district, where similar rocks are described and classified as pre-Cambrian in age. Subsequent, work will probably establish the contemporaneous origin of the rocks for the several scattered areas.

\section{CONCLUSIONS.}

The principal points developed in this study are summarized by Watson as follows:

1. The rocks of the area here described have been greatly altered through pressure and chemical metamorphism, as indicated in the prevailing secondary schistose structure and the abundant development of the secondary mineralschlorite, epidote, and hornblende-and small amounts of others. The alteration has advancedi sufficiently far in the schistose phases to destroy in most cases the original structure and minerals of the rock.

2. From structural, petrographic, and chemical evidences the rocks are shown to have been derived from an original andesite, but in their present much-altered state they are, according to present usage, more properly designated meta-andesites; that these are intimately associated with the corre-1 sponding volcanic clastics. Furthermore, the popular name "greenstone,".applied to many areas of greatly altered massive and schistose rocks along the Atlantic coast and Lake Superior regions, shown to have been derived from an original basic eruptive rock type, has equal application to the existing rocks of the Virgilina district.

3. The rocks are pre-Cambrian in age and represent an area of ancient volcanics similar to others described as occurring along the Atlantic coast region from eastern Canada to Georgia and Alabama and in the Lake Superior region.

4. The rocks are cut by numerous approximately parallel quartz veins which contain workable copper deposits. The veins are described as true fissure veins, and the ore is glance and bornite, without chalcopyrite and pyrite.

a Williams, G. H., The volcanic rocks of South Mountain, in Pennsylvanla and MaryIand: Am. Jour. Sci., 3d ser., vol. 44, 1892, pp. 493-494; Jour. Geology, vol. 2, 1894, pp. $1-31$.

${ }^{b}$ Bascom, F., Volcanic rocks of South Mountain, Pennsylvania : Bull. U. S. Geol. Survey No. 136,1896 , p. 30 ; Jour. Geology, vol. 1, 1893, pp. 813-832.

c Van Hise, C. R., Correlation paper's-Archean and Algonkian : Bull. U. S.-Geol. Survey No. 86, 1892.

${ }^{a}$ Keith, Arthur, op. cit:

- Nitze, H. B. C., op. cit. 
THE ORES.

The workable ores comprise glance and bornite mixed with quartz and country rock. At shallow depths cuprite and malachite occur as alteration products of the original sulphides. A little native copper occurs in places. Chalcopyrite, chalcocite, malachite, chrysocolla, cuprite, and native copper comprise all the known copper minerals. Chalcopyrite and pyrite are very rare, but were observed at several shafts on the High Hill property in 1901. The ores are free from arsenic and antimony, but show traces of gold and silver, particularly the latter. The following assays of rich ore from the Yancy mine in Person County, N. C., given by Hanna, ${ }^{a}$ show the relative values of gold, silver, and copper.

Assay of gray ores from Yancy mine, North Carolina.

\begin{tabular}{|c|c|c|c|}
\hline . & 1. & 2. & 3. \\
\hline 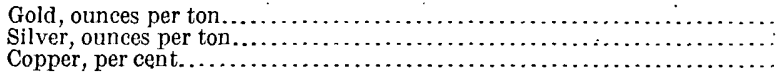 & $\begin{array}{l}0.1 \\
6.7 \\
48.17\end{array}$ & $\begin{array}{l}0.1 \\
5.1 \\
26.16\end{array}$ & $\begin{array}{r}0.1 \\
.5 \\
31.1\end{array}$ \\
\hline
\end{tabular}

The ores contain from one-half ounce to $2 \frac{1}{2}$ ounces per ton in silver, which is carried by the massively crystalline glance. Gold occurs in traces only, though gold-bearing quartz occurs on the borders of the copper area and is being worked at two mines.

The ore occurs characteristically in quartz veins. It also occurs in some places in finely divided particles disseminated through the more massive greenstone found in the schist. The workable ore is confined entirely to the veins. The vein stone or gangue consists principally of quartz with considerable calcite and epidote mixed locally. The altered country rock is intimately mixed with the quartz and calcite as thin lenses and stringers, which impart, in places, a banded structure to the vein. The included portions of the altered rock vary from mere films and dark streaks in the quartz to a preponderance of the schist with quartz infiltrated between the layers. The quartz is further frequently incased by layers of schist wrapped around it.

\section{THE VEINS.}

Though the district has many veins, some of them do not outcrop and few can be traced very far. Those of the High Hill and Yancy mines are exceptions, having well-defined outcrops, which can be followed for a mile or more in each case. In driving over the region one notices an abundance of white quartz, distributed in well-defined belts which correspond in a general way to the outcrops of the quartz

a Hanna, G. B., Ores of North Carolina : Geology of North Carolina, vol. 2, 1888, p. 220. 
veins. In general, there are a number of more or less parallel veins which strike $\mathrm{N}$. $5^{\circ}$ to $10^{\circ} \mathrm{E}$. and whose ends overlap. The veins cross the country rock in part, and are parallel in part to the schistosity. There is no gossan as commonly understood, and the surface outcrops of quartz are not much altered, but are solid and massive.

The mining development of the past five years shows that copper occurs in almost all of these veins in greater or less quantity. The most northerly mine is the High Hill, 9 miles north of Virgilina. The Person Consolidated mine is an equal distance south of this town, and other properties similar in character are said to have been found 5 or 6 miles still farther south. The ores occur in a belt at least 18 miles in length and about a mile wide.

The veins are lenticular deposits of quartz, connected, and forming, in the High Hill and Yancy mines, very uniform continuous quartz outcroppings at the surface. They are not persistent in width, however, and it is somewhat doubtful if they are all persistent at all for long distances as continuous bodies of quartz. Their lenticular structure is well illustrated (see fig. 9) by an example in the railroad cut near the town of Virgilina, where a quartz seam follows the plane of schistosity and is cut across by the railroad, so that it shows on both sides of the track. The decomposition of adjacent schist emphasizes the lenticular form of the quartz by disclosing the

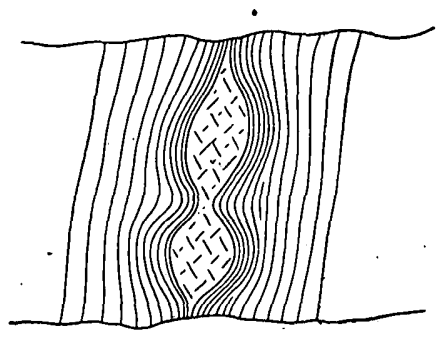

Figure 9.-Quartz lenticle of vein exposed in railway cut, Virgilina district, showing concentric slate shells.

concentric shelling of a slaty material that incases it. This structure is seen on a large scale at many of the mines. Where the schists are crossed by the main street of the town of Virgilina, small stringers of quartz are noted. The schists adjacent to this show green and blue copper stains when broken open.

The veins, like the gold veins of the Appalachian region, appear to be a succession of lenses connected by strings of quartz. The explamation given by Becker, ${ }^{a}$ which seems to be adequate, is graphically shown in figure 10, in which $a$ represents an irregular fracture traversing the metamorphic schists along which no movement has taken place, and $b$ a vertical section in which one wall has moved relatively upward and the other wall downward, producing lenticular spaces by a simple faulting amounting to a very few feet. In the case of the Blue Wing vein and others in the same district, the fracture has not been a simple one and the lenticular spaces are in part

a Becker, G. F., Trans. Am. Inst. Min. Eng., vol. 24, 1895, pp. 130-138. 
filled by the sheeted country rock. This structure is illustrated in the ideal diagram, figure 11.

The largest veins show outcrops nearly continuous for half a mile

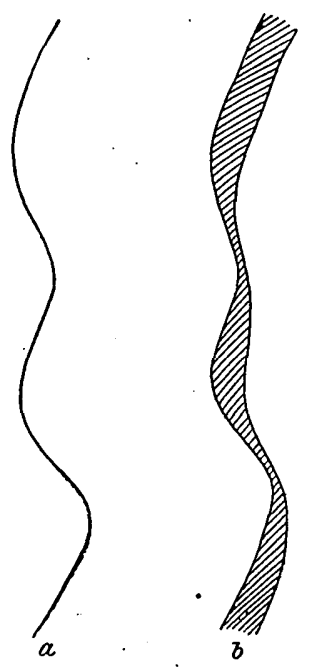

to a mile or more, and the underground workings show a continuous body of quartz; but even the largest veins have a bulbous or lenticular form, the vein pinching and widening both horizontally and vertically. The smaller veins show this very markedly, their lenses being in many places connected by a mere film or plate of quartz, which may be lacking in certain horizontal cross sections, so that the vein appears to have given out. In the largest veins, such as the High Hill, the outcrop is lacking in certain places, probably by reason of this thinning out.

Many parts of the veins show a very Figure 10.-Diagram il- marked bandlustrating the formation ed structure.
of lenticular openings by the movement of fissure 'This is comwalls.

monly seen near the walls, though in many places it prevails for the entire width of the vein. This banding is due to included plates of altered schist, in many places so thin as to be mere films, or to dark streakings in the white gangue. Many of these films are marked by ore, and in some of them the schist appears to have been replaçed by dark quartz, unlike the white quartz of the vein. In very many places this banded structure is most marked where the gangue consists largely of calcite. In some places it appears as if a slight movement had torn the walls raggedly apart and quartz had filled in cavities. (See fig. 11.)

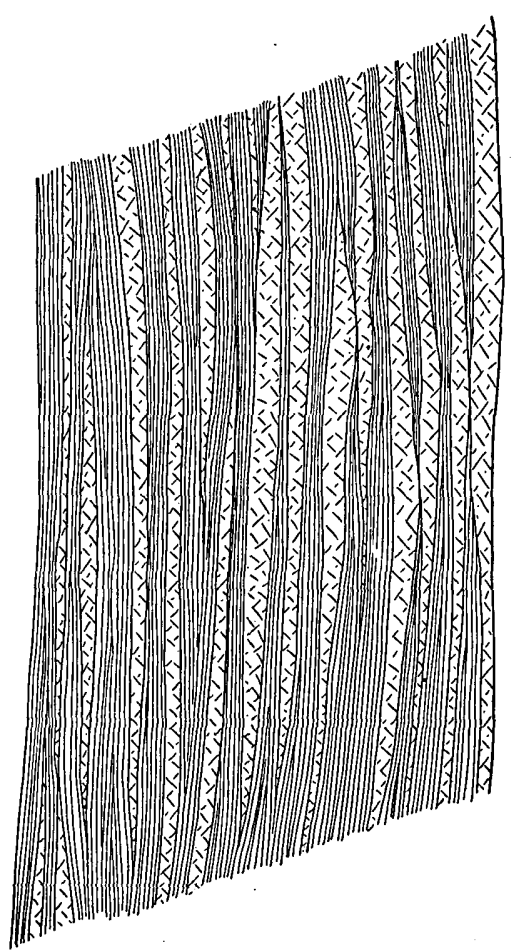

Figure 11.-Diagram illustrating structure of veins formed by the tearing apart of schist included between fault fissures or lying adjacent to fissures.

The quartz is commonly cased in a shelly micaceous material, locally called slate. In some places these films are undoubtedly of schist, 
but more generally they appear to be either an altered fault mud or an attrition material, possibly laminated by the pressure of the crystallizing quartz mass.

The footwall is generally well defined. In the Blue Wing mine it is regular in dip and strike and shows only slight undulations. The hanging wall is much less regular and swells out around the lenses. The cross dike of the Blue Wing mine interrupts the footwall and deflects the hanging wall, which becomes irregular as the vein passes through the tough rock. In the Holloway, which is a cross vein, the footwall is not regular but is deflected in and out as harder or softer bands of schist are crossed by the vein.

Slickensides were observed where the Blue Wing vein crosses the dike on the 150-foot level. The hang-

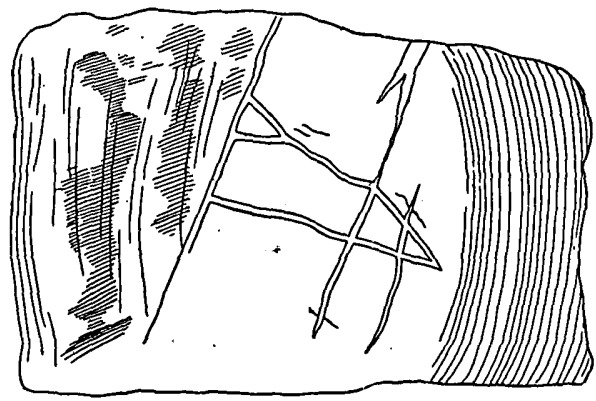

Figure 12.-Face of 300-foot level in Holloway mine, January, 1900 . On the left, black quartz. ose ore; in the center, white quartz stringers, cutting gangue. ing wall of the Holloway vein above the second level north shows flutings whose dip is about $70^{\circ} \mathrm{S}$. The ore shoots have a similar dip.

No clay selvage was observed at any of the mines, but water commonly penetrates the vein along the foot wall.

The veins have a generally uniform strike of N. $3^{\circ}$ to $5^{\circ} \mathrm{E}$. The vein of the Holloway is an exception, running N. $20^{\circ}$. E.; and there

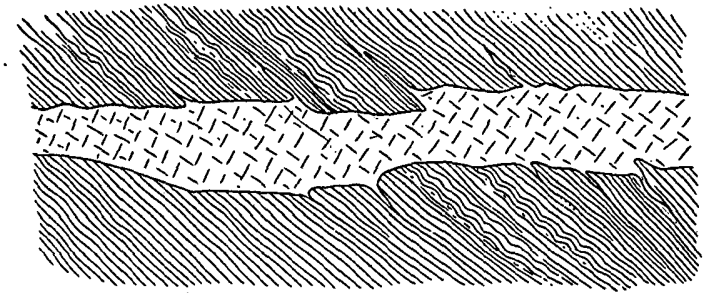

Figure 13.-Ideal horizontal cross section of Followay vein, showing quartz spurs following the foliation of the country schist. is also a cross vein on the Yancey property.

MINES:

HOLLOWAY MINE.

The Holloway mine, $3 \frac{1}{2}$ or 4 miles south of Virgilina, with which it is connected by a branch of the Southern Railway, was for several years a steady producer. In the three years from 1898 to 1901 , it was developed from a prospect pit 47 feet deep to a mine 300 feet deep, and yielded about 6,000 tons of ore, averaging 12 per cent for the second-class ore and running up to 30 per cent or more for first-class ore.

The mine is equipped with steam hoist, pumps, and air compressor, together with necessary buildings. It is developed by four levels at 
$75 ; 150,200$, and 300 feet, respectively, the fourth being at the bottom of the shaft.

The vein varies in width from 3 feet to 75 feet or more, showing the lenticular structure noticed on a small scale in the veins in the railroad cut (see p. 77), and, in fact, repeated in the ore body itself. In general, the footwall is fairly defined, showing a dip of $75^{\circ}$. The hanging wall is less defined, and both foot and hanging walls show irregularities, due doubtless to the crossing of the schists by the vein at a slight angle and the presence of projections where the rocks are slightly harder than the usual schists. The Holloway is a cross vein and its course, N. $15^{\circ}$ to $20^{\circ} \mathrm{E}$., is not that of most of the veins of the district. In the lower or third level of the mine the vein at the south face is 12 feet wide, and shows white and gray quartz, including $2 \frac{1}{2}$ feet of epidote and gray chalcocite. Figure 12 shows the roliing hanging wall and the ill-defined footwall on the fifth level. The vein sends out little feeders into the schists in stringers parallel to the schistosity (fig. 13).

On the third level, south of the shaft, the vein was lost in following the footwall, necessitating a short crosscut into the country rock. Figure 12 shows the cross section of the ore body on the fifth level south of the shaft. In general, the vein south of the shaft is well defined and has good walls up to the first level. The quartz is incased in a soft micaceous slate, not a gouge or selvage in the ordinary sense, which may be a schist-forming part of the country rock. Probably, however, it is an alteration of the sheared country rock, since it seems to be continuous across differing bands of schist and to be a constant accompaniment of the quartz. On the third level the vein pinches toward the shaft to about 3 feet, and continues with this width to the shaft and northward for a short distance, beyond which it widens to 6 or 8 feet. North of the shaft the vein is broken by a fault fissure dipping about $30^{\circ} \mathrm{E}$. and filled by a mud containing sharp angular fragments of ore and quartz. It does not throw the vein, though it shatters the walls.

The ore body on the third level is altered along cracks, showing films of green carbonates in both the ore and the white quartz. In the bottom of the shaft, however, no decomposition was observed. A prospect drift, started about 25 feet above the face of the third level, showed a black jaspery rock, with crossings of white quartz. No ore is exposed except on the north wall, where there is a slight green stain.

On the second level the vein is not accessible: North of the shaft a crosscut 8 feet into the hanging wall shows hard finely laminated micaceous schists, the schistosity of which makes an angle of about. $30^{\circ}$ with the vein. At the north end of this level the vein has a slaty hanging wall into which quartz feeders project. These feeders 
usually carry ore, but wedge out in a few feet. The quartz ore body does not show any true breccia, but in this, as in all mines of the district, there are the usual thin plated masses of decomposed schist. In general, the richer ore is found near the foot wall. No.definite association was observed between the occurrence of ore anci the character of the schists cut by the vein.

On the first level, 75 feet below the surface, south of the shaft, the rein is 133 feet wide but converges rapidly in both directions. The output in 1901 was 30 to 40 tons of ore per day. As tilen mined, the ore was picked and cobbed, and 18 to 20 tons per day were shipped, the remainder being thrown on the dump, awaiting some means of concentration. An air compressor running seven drills was at work, and a bucket hoist was used in the inclined shaft. The mine is situated on a rather gentle slope, so that facilities for dumps are not especially good.

A prospect shaft 30 or 40 feet deep, known as No. 5, shows vein matter but no quartz or ore. If situated on the vein it indicates a sharp twist at this point.

The Thomas mine (p. 83) is apparently on the direct extension of the Holloway vein, though that vein has not been traced continuously to it.

PERSON CONSOLIDATED MINES.

The Person Consolidated Copper and Gold Company's mines lie 8 miles south of Virgilina, and are on the same vein.

Yancey mine.-The mine formerly known as the Yancey is one of the oldest mines of the district, and was vigorously worked in 1892 , when concentrating works were erected, two shafts, one 150 feet and the other 88 feet deep, were sunk, and some ore was extracted. The old Yancey shaft is large and well timbered, and appears to be in good preservation.

The mine dump shows the usual gray and purple schist, with white quartz and epidote. The ore carries a gray copper glance. The schist on the dump is much decomposed and altered by long exposure, the fragments having slacked down to a rather small size with much soft micaceous débris. Some carbonate is still present and so is a little gray copper ore, spotted with bits of bornite.

The quartz vein was followed southward from the old Yancey shaft along a very strong outcrop, on a rising slope, to another old shaft, where, however, no ore was found. The course is N. $3^{\circ}$ to $5^{\circ}$ E., and the vein has, it is said, been traced for more than 1.5 miles south of the Yancey shaft. It has been exposed also in a cut a few feet south of the new opening made by Mr. Durgy.

A new shaft has been sunk a hundred yards south of the Yancey shaft. The rock extracted is purple and gray schist with some quartz. 
The rocks in the field near by are not schistose, but occur in angular blocks 6 to 20 inches across, showing a massive structure, and look rather like epidote bowlders, but probably are really a volcanic breccia. The openings are lower than the office and buildings constituting the mining settlement.

Durgy mine.-The Durgy mine shows a well-defined and persistent vein opened to a depth of 340 feet. The average width is about 8 feet, with extremes of 2 and 15 feet. The vein is not always copper bearing, and the quartz streak narrows down in places to a few inches with crush country rock as vein filling, but there is no reason why such a vein should not widen out beyond or below. The mine shows two ore shoots, the main or north one being 450 feet long. The map shows the extent of development work.

The mine is equipped with a good shaft, hoist, compressor, engines, boilers, etc., with all necessary houses, and with a concentrating mill.

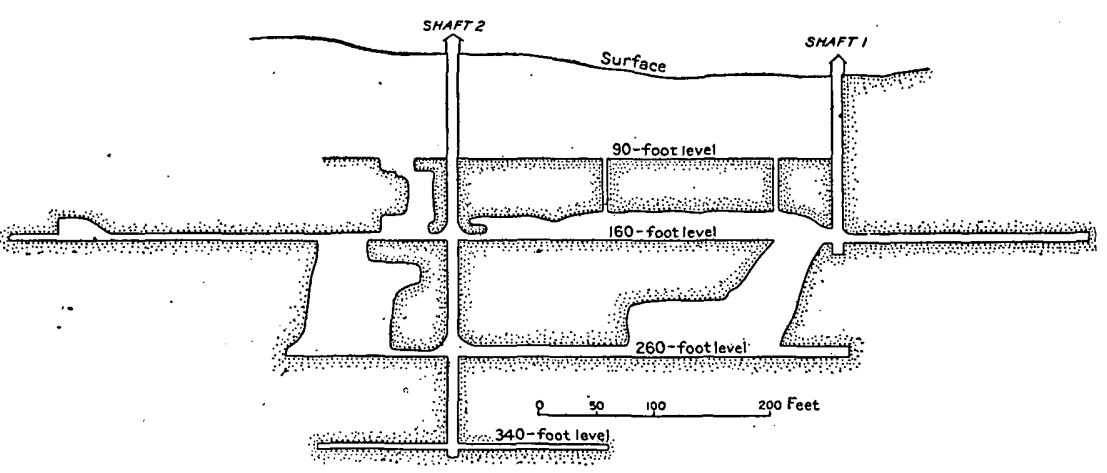

Frgure 14.-Section of Durgy mine, Virgilina district, Virginia.

Shaft No. 1-64 is a new one alongside of an old pit one-fourth mile northeast of the Yancey. The foot. wall is a rather massive epidote rock; the hanging wall a fissile gray mica schist, resembling that common to all the veins. The ore shoot where crossed by the shaft is about 15 inches wide, the gray glance occuring in white quartz, with some impregnated schist. The vein is composed of white "filling quartz" but is in part a breccia. Ore and epidote seem to replace square and angular fragments embedded in white quartz. In other masses the glance appears in branches of mossy aggregates, penetrating white quartz, or is found in threads in the altered schist.

\section{WALL MINE.}

The Halifax Mining Company owns the Wall mine. The vein has an average width of 3.75 feet and is developed by a shaft 135 feet deep, with drifts north and south for 50 and 40 feet, respectively. The vein ranges in width from $2 \frac{1}{2}$ to $5 \frac{1}{2}$ feet and carries from 0.2 per cent to 3 per cent of copper. 
CHAPPEL MINE.

The Chappel mine lies northeast of the High Hill mine. The workings consist of two shafts, one 87 the other 55 feet deep, and. about 150 feet of drifting.

COPPER WORLD MINE.

The Copper World mine was first opened in 1882. A shaft 60 feet deep, with drifts at 30 and 60 feet, was sunk by the owner, Colonel Stiff, in 1901. The vein shows the usual white quartz, with some epidote, incased in gray and purple schist. But one ore shoot was crossed, from which 8 to 10 tons of high-grade glance ore were stoped and shipped.

FRAZIER MINE.

The Frazier mine deposit is like that in the "native" shaft of the Eustis property. It shows no defined vein, but contains quartz stringers and ore strealkings in cracks and fissure seams in a very massive epidote rock. The ore is bornite.

\section{THOMAS MINE.}

The Thomas mine is about one-half mile from the Holloway, and is supposed to be on the direct continuation of the same vein. The mine was not working when visited in 1901, and the ore dump had been thoroughly cleaned up. The gangue is white quartz with included fragments of slate, which generally show a parallel banding, so that it is difficult to account for them as replacement nuclei. Such fragments could not exist in open space and hence the filling quartz, which is clearly not replacement, must have been largely inserted between the schist plates. The rock distinctly shows its former igneous origin and is markedly porphyritic. It is an altered andesite.

\section{ANACONDA MINE.}

The Anaconda mine is located close by the road, in a field 1.5 miles north of Virgilina. The Anaconda vein lies in the green schists and is opened by a shaft 5 by 7 feet wide and 140 feet deep. Drifts 85 and 115 feet long, respectively, run north and south on the 100-foot level.

The ore shoot is from 4 to 18 inches wide and carries a 2 to 4 inch. streak of 15 per cent copper ore, the balance averaging about 4 per cent. The vein outside of the ore shoot is well defined and is from 12 to 24 inches wide, but it is barren or nearly so. The ore is a mixture of glance and gray copper in quartz. The dump shows bright green schist, largely impregnated with epidote. About seven 
carloads of ore, carrying from 3 per cent of copper in the first carload to 12 per cent in the last five, have been shipped from this mine.

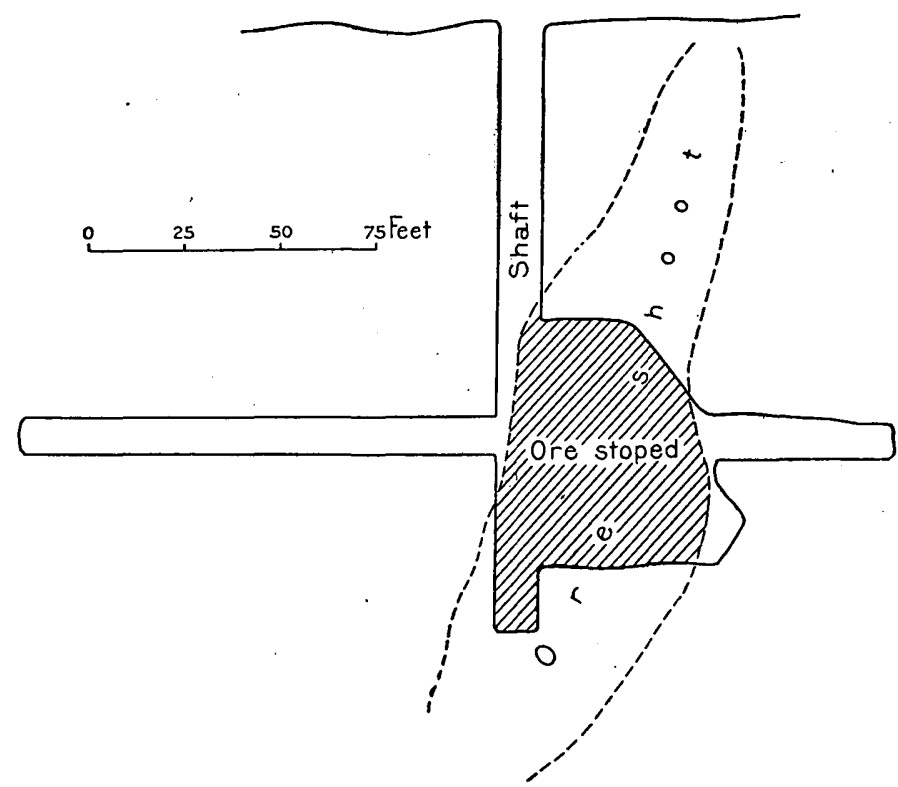

Figure 15.-Section of Anaconda mine, Virgilina district, Virginia.

- BLUE WING MINE.

The Blue Wing mine is situated about $1 \frac{1}{4}$ miles south of Virgilina, in Granville County, N. C. The gangue is quartz and calcite.

The Blue Wing vein is an excellent example of a complex fissure vein, in which the space between two fault planes is closely sheeted

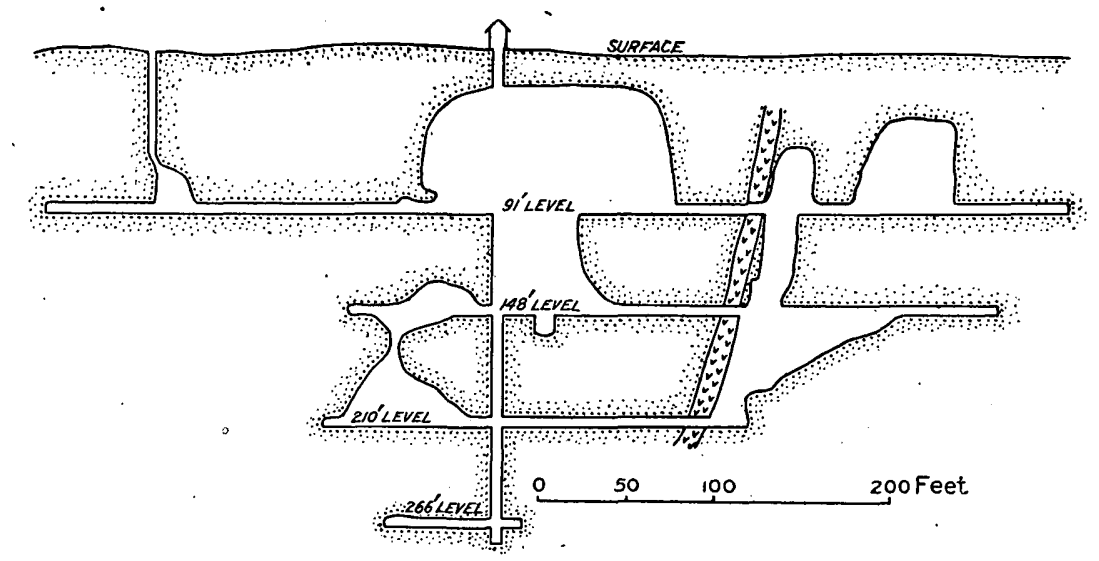

Figure 16.-Section of Blue Wing mine, Virgilina district, Virginia.

by thin parallel plates, more or less torn apart. The ore occurred in part as filling along narrow clefts between these broken sheets. and in part as minute impregnation of quartz lenses in the altered 
rock itself. Definite evidence of metasomatic replacement is apparent, but the bulk of the ore body is quartz, filling open spaces. This structure is shown in figure 17. Where the vein crosses the diabase. dike, the fracture walls are displaced and the fissure becomes a shattered zone between fault planes.

The vein is opened by a shaft 266 feet deep and a horizontal drift of 600 feet. The width averages 4 feet but varies considerably. The ore will average about 2 per cent copper and fourfifths ounce silver per ton. It carries considerable calcite, the excess of silica being about 60 per cent.

There is also a shaft on the Glasscock tract, 203 feet deep, and one on the Julia Tuck tract, 125 feet deep.

The Blue Wing shaft is over 180 feet deep and has 100-foot and 150 - foot levels. The 100-foot level, which runs 348 feet north and 115 feet south of the shaft, shows a vein of very constant width. In fact it maintains a width of about 3 feet from the

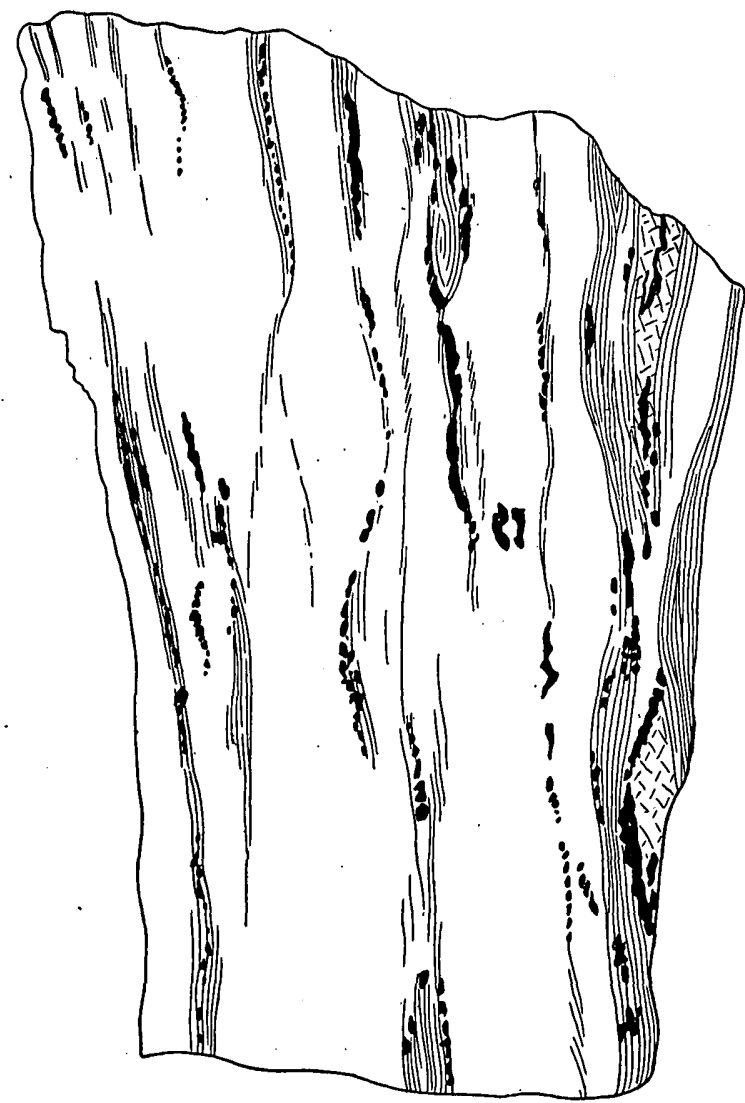

Figure 1.7.- Specimen of ore from Blue Wing mine, Virginia, showing banded structure. The white ground is calcite, containing a little quartz in small lenses; the solid black is bornite; the parallel lines represent schist; the crosshatching quartz. One-half natural size. surface down to the 100-foot level and shows well-defined foot and hanging walls. 'The ground has been stoped out, so that no ore is now known above the 100 -foot level.

Figure 18 shows the face at the north end of the 100-foot level; figure 19, the roof above the stope, a short distance south of the face; figure 20 , a sketch of the south face of the same level, showing quartz lenses holding ore and the slate casing to the ore lenses. This south 
face shows barren white quartz and calcite on the hanging wall, and on the foot wall dark-gray sulphide slate with quartz streaks, holding parallel threads or films of what looks like slate dotted with ore. Ore (harder and darker in color) also occurs in the casing. In many

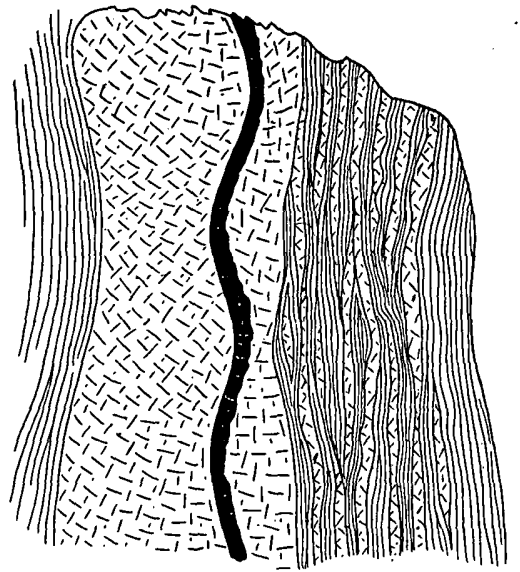

Figure 18.-Blue Wing vein in face of 100 foot level north. On the right, gray slate, with droppers and plates of white quartz. In the center, white calcite with some quartz and a streak of bornite (solid black). On the left, calcite and quartz resting against wall of schist. places the ore body presents a streaked or ribboned appearance, due, not to crustification or to recent movement of the vein, but to partly replaced sheets of schist.

A dike 12 feet wide cuts across the schists and apparently cuts off the vein. This dike is followed continuously down to the 150 -foot level and is there crossed by the vein, which is not well defined and consists of a mass of breccia cemented by calcite and quartz. At this level also the dike shows unmistakable evidence of slickensides and shearing by the vein. So far as could be made out, the dike shows no very great decomposition; it simply pinches the vein because it is very hard and resistant. No definite striations were recognized in this vein, such as were seen in the Holloway. Much of the vein matter shows included fragments of schist, in places angular, but more commonly in thin platy masses. From the 100

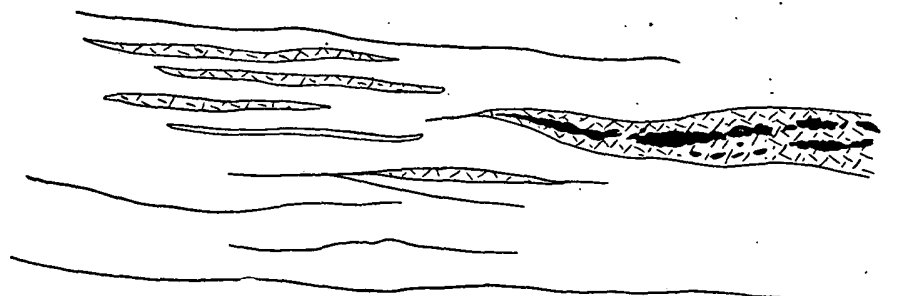

Figure 19.-BIue Wing vein, in roof over stope above the 100-foot level, 350 feet south of shaft. On the left, calcite and a little white quartz, with dark streaks of slaty matter and spots of ore. On the right, ore in dark quartz.

to the 150 foot level a continuous vein section is seen; but as the stopes have been exhausted of workable ore, only the barren gangue now shows. The face supplies a remarkably good example of the streaked or banded structure of these veins, the contrast between the 
white calcite and the dark schist being especially. well marked. The clark schist impregnated with ore shows evidence of the metasomatism that formed the ore at this place.

\section{FIGH HILL MINE.}

In 1904 the most important development in the Virginia part of the field was at the Virginia Copper Company's High Hill mine, where there are several well-defined persistent veins.

In 1904 the main or principal vein was prospected for 9,702 feet and the second parallel vein for 6,204 feet. ${ }^{a}$ Both veins were found to be mineralized for the entire length explored. In March, 1904, the No. 4 shaft was 339 feet deep and the No. 3 shaft 267 feet deep, both vertical. The aggregate amount of shaft sinking is 1,189 feet, with 2,306 feet of levels opened up but not stoped.

The equipment includes two doubledrum 50-horsepower Lidgerwood steam hoists, each capable of hoisting 4,000 pounds at a speed of 400 feet per minute, or 400 tons ore per day; two 150horsepower horizontal return tubular boilers; a McKiernan 24 by 24 by 30 inch air compressor, with a capacity of 1,400 cubic feet of free air per minute; a 54 by 12 inch air receiver, etc., to run twenty $3 \frac{1}{4}$-inch drills. Seven McKiernan and five Sullivan rock drills are used. The mill contains Blake and Sturtevant crushers, pumps to handle 600,000 gallons per day, a picking belt, trammels, jigs, hydraulic classifiers, and a Wilfley table.

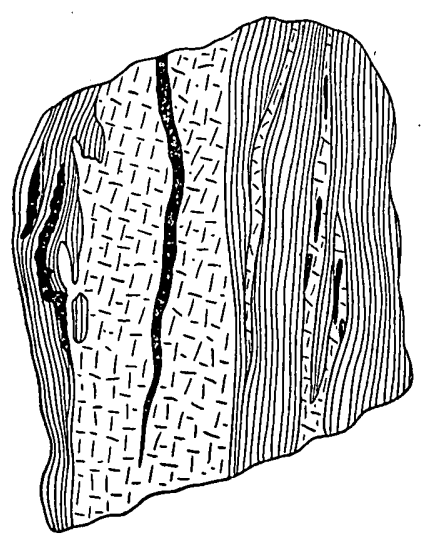

Figure 20.-Blue Wing vein at the south face of the 100-foot level. On the right, slate carrying streaks of quartz. In the middle, bafren quartz and calcite carrying ore streak in center. On the left, schist carrying quartz lenses and ore-the latter both in independent streaks and as a casing about the lenses for one-fourth inch to two inches from the quartz.

Up to March, 1904, this company had produced 212,4.55 pounds of refined copper and 2,485 ounces of refined silver. The concentrates carry $\$ 4$ per ton in gold.

The ore is not in well-defined shoots, but is disseminated and will sample 2 per cent of copper and an ounce of silver per ton.

The following results of various samples of ore from the mine have been furnished by the owners of the High Hill property:

a These statements are based on a letter from Mr. C. P. Voorhees, president of the company. 
Metallic contents of ore taken from High Hill property.

\begin{tabular}{|c|c|c|c|c|}
\hline Number. & Copper. & Silver. & \multicolumn{2}{|c|}{ Gold. } \\
\hline 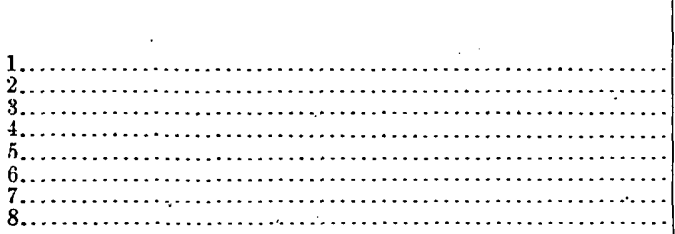 & $\begin{array}{r}\text { Per cent. } \\
26.88 \\
9.29 \\
1.19 \\
8.00 \\
2.01 \\
7.92 \\
1.27\end{array}$ & $\begin{array}{r}\text { Ounces } \\
\text { per ton. } \\
7.05 \\
2.80 \\
.80 \\
.10 \\
1.20 \\
.50 \\
1.50 \\
\text { Trace. }\end{array}$ & $\begin{array}{r}\text { Ounces } \\
\text { per ton. } \\
0.04 \\
.02 \\
.01 \\
\text { Trace. } \\
\text { Trace. } \\
\text { Trace. } \\
\text { Trace. }\end{array}$ & 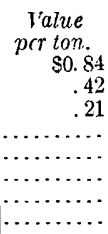 \\
\hline
\end{tabular}

1. Selected ore from No. 2 shaft.

2. Ordinary ore from ore shoot cut in No. 2 shaft.

3. Sample from face of north drift, 65-foot level, No. 4 shaft.

4. Sample across the hanging-wall layer of vein, 2 feet wide; stope, 65-foot level No. 4 shaft

5. Middle streak, 20 inches thick, composed of ore and slate, same face as 4 .

6 . Foot-wall Jayer of vein, 6 feet 8 inches thick; same face as 4 and 5 .

7. Face of north drift, 150 -foot level No. 4 shaft.

8. Face of south drift, 65 -foot level No. 4 shaft.

The property comprises 612 acres crossed by two persistent veins, the western, or High Hill, vein being the best developed. This is a very persistent vein of white quartz traceable for 3 miles, or from Hyco River to a point a mile south of the company's holdings. It

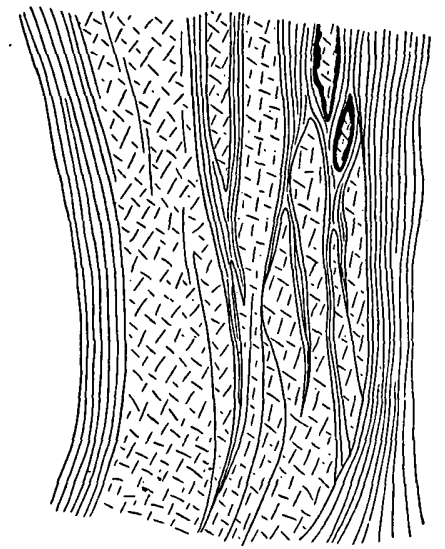

Figure 21.-High Hill vein at shaft No. 4, north face of 60 -foot level. Vein 8 to 9 feet wide. Soft fissile mica schist on the right. has been opened by an adit (tunnel) and by twelve shafts. The adit was inaccessible and the shafts filled with water in July, 1905, but the author had made a careful though brief examination of these and other workings two years before.

The workings show that the vein, though persistent, varies in width from 6 inches to 15 feet, the average width being 4 feet. It is almost continuously copper bearing, though in varying amount. The ore shoot developed by shafts No. 3 and No. 4 is 1,000 feet long and that by No. 2 shaft is 200 feet long.

Figure 21 represents the structure of the north face of the 60 -foot level in shaft No. 4 . Figure 22 shows the north end of the shaft at the bottom. The ore shoot is said to occur along the footwall and is commonly believed to have a southerly pitch. Its character is the same in all the shafts, except, of course, that in the shallow pits only the oxidized ores are found. The bornite decomposes along cracks and films to malachite, and in the ore stacked about shafts Nos. 1 and 2 masses of bornite are seen altered to covel- 
lite and nests of specular iron ore. Malachite is also abundant, and drusy quartz of secondary formation appears. The lenticular form of the ore body is shown in the sketch already given and also in figure 23 , representing the wall of No. 9 shaft.

The shafts nearest Hyco River are 107 feet deep, and are connected by a 180 -foot level, which is continued 130 feet farther south--nearly to daylight-from the shaft. No. 8 shaft is 72 feet deep and has a 9 -foot drift at bottom. The gold and silver values are variable. Occasionally fair assays have been made; for instance, a sample from the stock piles of first-class ore yielded 8.46 ounces gold per ton; but the returns of the carload shipments show but a few ounces of silver and an average of but 0.01 ounce gold.

\section{DOROTHY · MINE.}

The Dorothy mine is located on the west ridge, has two shafts 100 and 60 feet deep,

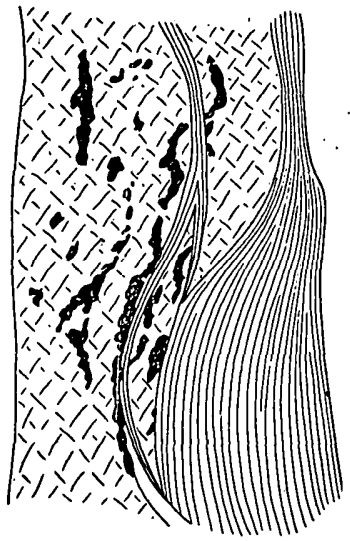

Figum 22.-High Hill vein, north face, at bottom of shaft No. 4. January 29 1900. Vein 8 to 9 feet wide. Ore shown in solid black. respectively, with levels at 25 and 100 feet. The ore is bornite and glance in a quartz gangue. One carload has been shipped and several are on the dump.

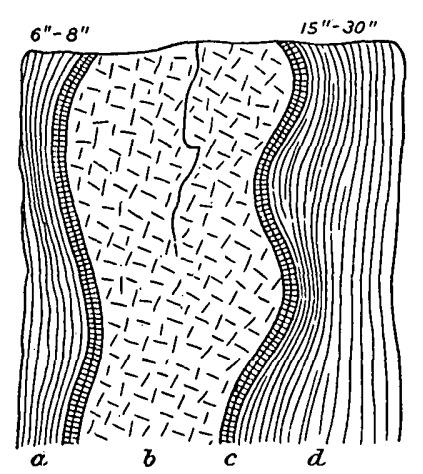

Figune 23.-High Hill vein, Virginia. Exposure ia south wall of: shaft No. 9: (a) Decomposed schist; (b) quartz; (c) gray schist, altered and showing green copper stains; (d) reddish decomposed schist.
ALABEMARLE COUNTY (SOUTHWEST MOUNTAIN).

A vein that was worked at one time as an iron deposit cuts through micaceous schist northeast of Charlottesville, in Albemarle County. The upper part of this vein, the gossan, is composed of limonite, which was shipped to the Pittsburg furnaces.

The mines are in the rolling foothill country at the west base of Southwest Mountain, on a small fork of North Fork of Rivanna River, about 2 miles east of Stony Point and one-fourth mile from the main Charlottesville turnpike. The branch road from the turnpike to the railroad station passes through the property. This foothill region is characterized by flat-topped ridges and perennial. streams coursing through deeply cut valleys. The elevation is about 
400 feet above sea level, and the country is in large part cleared and under cultivation. The mines lie on both sides of the branch road, diverging from the pike at the church and following down Busher Creek. They are $2 \frac{1}{2}$ miles from the railroad and 12 miles from Chariottesville.

The history of the Stony Point mine, so far as it can be ascertained, is short. It was discovered about 1878 and purchased by Major Mason, who worked the property in 1885. A spur of the Virginia Midland Railroad (Southern Railway) was run up to the property, partly for the purpose of loading ties cut on the neighboring mountain but mainly in order to ship the iron ore. Years afterward Major Mason's foreman stated that mining was discontinued on the property about 1890 , because the owner had opened up a newly purchased deposit of magnetite in Pittsylvania County which proved more remunerative; also that the iron ore (gossan) of this vein carried a troublesome amount of silica and the increasing amount of copper ore was detrimental to its use in iron smelting. About 2,500 carloads of the iron ore were shipped. According to this same authority the portion of the vein north of the road was developed by an inclined shaft 130 feet deep and a drainage tunnel run in a little above the creek level. Some water was encountered in the shaft and an 8-horsepower Cameron pump was installed to drain the working, but so large a pump was not needed. The consumption of fuel was from 1 to $1 \frac{1}{2}$ cords of wood a day. The ore was roughly culled and was shipped to the Pittsburg furnaces. Some of it was said to run 75 per cent iron in carload lots. The railroad spur is about 2 miles long, and in 1905 was still in a fair state of preservation except for one trestle near the main line.

The property consists of about 100 acres of land, covering about three-quarters of a mile of vein outcrop, of which one-quarter mile lies north of the wagon road, and is held by mining rights only. On the south side of the road the vein extends through a tract of woodland which is owned in fee simple. This woodland is covered by about twenty years' growth of new timber and with soil from 2 to 3 feet deep. The vein is traceable up the slopes above the little creek to the flat summit of the ridge, the outcrop being practically continuous. Along the summit, pits and crosscuts every few yards expose what is practically a continuous outcrop. Much white quartz is strewn over the ground, but it does not appear to come from the vein.

The course of the vein is $\mathrm{N}$. $35^{\circ} \mathrm{E}$. (magnetic) in the northern portion of the property, and the dip is $55^{\circ} \mathrm{S}$. as determined in the shaft. To the southward through the timber the course of the vein is $\mathrm{S} .80^{\circ} \mathrm{W}$. 
The vein is from 5 to 6 feet wide and maintains a nearly uniform width throughout the entire extent exposed. It consists of a solid mass of gossan, which when broken appears more or less cellular, with siliceous portions and occasionally with quartz streaks.

In 1906 the property north of the road showed several large dump heaps of ore and waste, the largest coming from the inclined shaft previously mentioned. The ore dump is composed of a rather siliceous iron ore and of scattered lumps of milky to horn-like white quartz, 15 or more inches thick, well banded with thin layers of chalcopyrite, in some of which the quartz is spotted with small specks of chalcopyrite. No pyrite was seen either in the quartz or in the altered schists about the vein. Some of the cellular masses of limonite contain undecomposed nucleal masses of chalcopyrite. The country rock consists of bleached and altered, thinly foliated, sericitic schists. The hanging-wall rock is bleached and rusty, and the footwall rock is buff and olive colored and is less altered. No sign of eruptive dikes was seen in the immediate vicinity of the vein, but on the main turnpike, one-quarter mile to the east, dark-green exposures of what is probably an altered basic dike were noticed.

The only underground work accessible in 1905 was a portion of a tunnel about 20 feet below the surface of the ground. This was reached by going down an old caved shaft and turning southwest along the vein. An examination was also made of exposures in the old shafts sunk every few yards to the northeast along the vein until it passes into the cultivated field that slopes northward to the level of the small creek, along which exposures are said to exist. From the road southward the outcrops were carefully examined to see whether there were any signs of lenticular masses or whether the vein appeared to be a continuous exposure. So far as the openings afford any evidence, the vein is one continuous mass of gossan. In ground plan the vein appears to conform very closely to the foliation of the schist, but in the exposures seen in the shaft north of the road it appears to dip a little more steeply than the schists.

From the foregoing facts the following deductions are drawn:

First, the vein has been altered to a depth of at least 130 feet, or about 25 to 30 feet below the present water level, into a somewhat siliceous limonite. As no pyrite was seen in any of the quartzose portions of this gossan nor in the adjacent wall rocks, the iron must have been derived from chalcopyrite.

Second, as the base of the gossan has not yet been reached there is a fair presumption that several feet of secondary copper glance, the so-called black oxide ores, will be found between the gossan and the unaltered primary ore. This is borne out by experience at Ducktown, at Ore Knob, and at various other localities throughout the 
Appalachian belt. As the samples of chalcopyrite which have been assayed yielded $\$ 5$ per ton in gold and 16 per cent in copper, it is fair to assume that the gossan also carried a gold content and that the gold in the primary unaltered sulphide ore will be a valuable constituent. As the vein appears to be quite regular in strike and to be unfaulted, development work will be relatively cheap. Timbering will be needed, as the hanging wall scales off and needs stulls. The footwall is well defined and fairly uniform. Development work, if attempted, should consist of a shaft of sufficient depth to reach the unaltered sulphides, followed by drifting along the vein in order to find out the average assay value of the unaltered ore.

TRIASSIC AREA (LOUDOUN, CULPEPER, ORANGE, AND AMHER'T COUNTIES).

Sparsely disseminated copper compounds are contained in the Triassic red sandstones and shales in places, but are generally too diffused to be profitably worked. Attempts were made in the early part of the last century to mine the ores over parts of Loudoun, Culpeper, and Orange counties. In places the area of mineralization is extensive and considerable work has been done. No veins have been found and no well-defined horizon exists. The ores occur for the most part as films or thin coatings of malachite on the joint surfaces and as disseminated grains of the sulphide and phosphate of copper through the rock. Some rich specimens of copper glance and copper phosphate are obtained, but they are rare.

Five miles east of Leesburg, near Sugar Run, in Loudoun County, the Triassic rocks include greenish or bluish calcareous sandstones and shales, intercalated in the red rocks. These light-colored beds contain films or thin coatings of malachite (green carbonate of copper) on joint surfaces and locally carry specks of the phosphate of copper and of copper glance, commonly associated with carbonized vegetable stems and imperfect leaf impressions. "The area of mineralization is extensive and considerable work has been done, but the ore is too generally diffused to be profitably worked." a

Near Stevensburg, 10 miles east of Culpeper, copper-bearing shales were formerly worked for these ores. No veins have been found and no well-defined ore horizon is seen in the workings, the thin stainings being sparsely disseminated. Though rich specimens do occur, they are rare, and the metal is too sparse to pay for working. Unfortunately the brilliant color of the carbonate gives false impressions of richness, and much time and money has been wasted in attempts to work the rocks. In no instance is the ore in sufficient quantity to warrant mining.

${ }^{a}$ Keith, Arthur, Harpers Ferry folio (No. 10), Geol. Atlas U. S., U. S. Geol. Survey, 1894. 
Professor Rogers's observations (see p. 94) on the ores of this area remain true to-day. He noted the presence of green copper carbonate and copper glance in these beds. Besides the green carbonate found as films and specks of ore associated with carbonized vegetable stems and impressions, and contained in calcareous shales, phosphate of copper and glance occur in good specimens. Splendid specimens of glance are often found. Professor Rogers ${ }^{a}$ adds that this indication "has unhappily kept alive the hope of discovering in these shales veins of a workable copper ore and has led to repeated enterprises in mining, from which no really profitable result appears ever to have been derived. Most of the openings, either ancient or modern, have disclosed nothing more than a calcareous shale slightly filmed with the green carbonate, and making in some cases a superficial show of richness where analysis discovers only an insignificant amount of the enticing mineral."

Orange County contains areas of copper-stained rock in the Triassic sandstones. Taylor's copper mine is mentioned by Professor Rogers, who says: "Though opened with high expectations of profit [it] has long been abandoned." 6

Amherst County contains green-stained rocks at the Folly, and numerous old openings attest the endeavor of early explorers to find workable deposits. "No distinct vein or bed of copper ore is indicated, but rather an impregnation of the talcose rock of the neighborhood, more or less strongly, with the above-mentioned compounds of the metal. *** In some of these places the manufacture of copper has been attempted, but without the success that would justify a prosecution of the enterprise." .

\section{BLUE RIDGE REGION.}

HISTORY.

The Blue Ridge copper region lies in the northern part of Virginia, extending from near Front Royal southward and including parts of Warren, Fauquier, Rappahannock, Madison, Page, and Greene. counties.

The copper ores of the Blue Ridge have been known for a long time. Since the earliest settlement of the country nuggets of native copper of all sizes from small particles up to masses many pounds in weight have from time to time been found in rocky exposures and inclosed in shattered bowlders over many parts of the Blue Ridge. This native copper undoubtedly furnished the Indian

a A leprint of annual reports and other papers on the geology of the Virginias, 1884, p. 133 .

${ }^{b}$ Idem, pp. 87,88 ,

c Idem, p. 87 . 
tribes with the metal from which their ornaments and axes were made. In colonial days the ores were known to various settlers and a few attempts were made to extract the metal.

Prof. W. B. Rogers, who was State geologist of Virginia from 1835 to 1841 , inclusive, and whose conclusions are as true now as when they were written, writes of the deposits as follows: ${ }^{a}$

In many parts of the Blue Ridge, in the neighborhood of the transverse belt whose general characters I am describing, virgin copper and the green carbonate have been discovered in thin veins and small masses in the body of quartzose and epidotic rock. In the neighborhood of Stony Man, one of the loftiest and wildest of the peaks of this range, near Swift Run gap, and at several other points, small specimens have been picked up, and their richness both in the metal and its carbonate have inspired the sanguine with a confident belief of the existence in the bosom of the mountain of treasures of this nature of exhaustless extent. But in regard to all such anticipations it should be borne in mind that the quantity is not less important than the quality of the ore to stamp it with real value, and that until far more minute and extensive researches in regard to these ores have been made in the localities where they are found than have ever hitherto been attempted, it will be impossible to have any grounds for judging of their extent, and it will be as unwise as hazardous to engage in expensive schemes of mining on their account. Yet $I$ would not have it understood that such researches are to be considered as hopeless or inexpedient. I would rather rejoice to see investigation active; at the same time, in duty to the public interest, I would caution against that precipitate and oversanguine spirit-a spirit which in no instance is more likely to terminate in loss and disappointment than when excited by objects of this nature, involved as they may be, even to the diligent scientific explorer, in unavoidable obscurity and doubt.

During the " copper fever," which prevailed throughout the Southern States during the years 1854-1856 as a result of the discovery of the rich black copper ores of the "gossan lead" of southwest Virginia and of Ducktown, Tenn., large sums of money were expended in the Blue Ridge region-over $\$ 300,000$, it is reported, on the Stony Man property alone. At the beginning of the war all mining operations were suspended and were not resumed for twenty years or more.

Keith noted the existence of copper ores in 1894, saying: ${ }^{b}$

Deposits of copper in the schists have long excited interest and led to mining operations. The amount of ore, however, appears not to have justified any considerable work. Such deposits have been worked on the Blue Ridge east of Front Royal and along the northern end of South Mountain.

More recently numerous attempts were made to work ores in the vicinity of Front Royal, Bentonville, and Luray. At the latter locality a property near Ida was developed by a shaft 300 feet deep; but with this exception the workings up to 1905 were relatively shallow. So far as information is available none of the shafts exceeded 90 feet in depth. This shows that although much money and

${ }^{a}$ Geology of the Virginias, 1884, reprint, p. 134.

- ${ }^{b}$ Geology of Catoctin belt: Fourteenth Ann. Rept. U. S. Geol. Survey, pt. 2, 1894, p. 309. 
effort have been expended the work has been comparatively superficial and the extent of the ore bodies in depth had not been satisfactorily answered. In 1905, six companies were prosecuting work and some prospecting was in progress by private individuals, but up to 1906 not a single producing mine had been developed. Numerous stock companies have been formed to acquire and work such properties, and both local and outside investors have furnished considerable sums of money for development purposes. It is therefore important to determine whether or not such work is justified by the deposits themselves. To determine this all known copper prospects were visited by the writer. The following notes are based on his personal observations:

GEOLOGY.

The Blue Ridge region of Virginia is a mountainous tract extending from Harpers Ferry southwestward to the State line. It is made up of a fairly continuous and well-defined ridge, which in places is narrow, as in the vicinity of Harpers Ferry, and in other places spreads out into a number of connected mountains, as in the vicinity of Front Royal. In general the ridge marks the boundary between the older crystalline rocks of the Piedmont Plain on the east and the younger Paleozoic sediments of the Appalachian Valley on the west. It also for the most part forms the divide between the Atlantic and the Gulf drainage, though several streams rise west of it and flow eastward through it in deep and narrow gorges.

Throughout its entire length the Blue Ridge.shows a central core of igneous rocks, mostly of a dense basaltic rock flanked by granite and other igneous rocks, often altered to schistose shalelike rock. Resting against these rocks, usually at the base of the mountains, is a folded sedimentary series, whose basal bed is a quartzite that forms a nearly continuous ledge along the western flank.

The basaltic rock, which is dense, heavy, dark colored, and varies in character from a basalt to a diabase, is at some places altered and schistose. This character prevails in the Harpers Ferry region, where the rock is known as the Catoctin schist. The basic rocks are, according to Keith, ${ }^{a}$ of two varieties, a lower diabase sheet and an upper basaltic sheet, both altered, and the upper one largely epidotized. It is known that the rocks are eruptive and probably represent an accumulation of lava flows, for they are known to rest on a surface flow of andesite near Front Royal, and must therefore themselves be flows. The basaltic area is continuous from the Pennsylvania line halfway through Virginia with an average width of 20 miles, although, of course, many of the cxisting exposures are

a lieith, A., Geology of the Catoctin belt: Fuurteenth Ann. Rept. U. S. Geol. Survey, pt. 2. 
not so wide. The rocks have been generally much altered by dynamic metamorphism and secular decay and now in part form a greenish chloritic and epidotic schist, which Keith ${ }^{a}$ designated the Catoctin schist.

The Catoctin schist is penetrated by a younger and clearly intrusive granite, the two being in places intricately intermingled, so that outside of the main belts of each there are areas where the interrelations can be shown only on a very large scale map. Near the contacts the granite is altered to a fine schist or finely laminated shale or may even resemble a leafy black slate in which no trace of the original character can be recognized by the eye. This is the material seen along the road to the copper mine south of Linden, near the schoolhouse.

At Linden the rock is massive and commonly shows well-defined basaltic characters. It is undoubtedly a part of the younger or upper epidote schist of the Catoctin formation as described by Keith. This upper part, familiarly known as greenstone, is an altered basalt, in which, by the processes of ordinary hydrometamorphism, epidote has been so abundantly developed as to give the rock its characteristic color of bluish green when fresh and yellowish green when weathered. It contains so much epidote that it is very enduring. Knobs and bunches of epidote frequently protrude above the corroded surface. In this region the rock is not schistose except in shear zones, in which the fractures are marked by silky chlorite, often in bunches. Copper occurs in both the schist and the greenstone.

WARREN COUNTY.

STRUCTURAL RELATIONS.

The copper ores in the region east and south of Front Royal have attracted attention for many years. Several mining companies have done more or less exploration work, and their shafts and tunnels have afforded favorable exposures for careful observation of geologic conditions. The district embraces the main Blue Ridge summit, extending from Linden southward to Elkton.

The topography is the direct result of differential erosion of hard and soft rocks, and is therefore a key to a real geologic distribution. The age of the sedimentary rocks near Front Royal is shown by determinable fossils to be Cambro-Ordovician. These sedimentary rocks form part of a broad anticlinal that once arched over the Blue Ridge. The arch is crumpled into several synclines and is broken by faults, mainly of the thrust type. Two of these faults coalesce east of Front Royal, so that the sandstone disappears to the south and the igneous rocks are faulted against limestones. 
The volcanic rocks near Front Royal are of four types, namely, andesite, basalt, Catoctin schist, and granite. East and northeast of the town a small area of andesite forms a narrow strip between the diabase of the Blue Ridge summit and the Cambrian sandstone. Part of this andesite is tuffaceous, and east of Front Royal it is dragged out along the fault line into lustrous micaceous slates. Granite occurs in large masses throughout the region to the east. A considerable area formerly mapped as granite occurs along the western slope of Dickeys Hill, but the material, as seen in the vicinity of Brownsville, appears to be syenite.

The granite on the east side of the Blue Ridge is peculiar, as tongues run from it out into the diabase (Catoctin schist) and contain included fragments of that rock. Such tongues occur east of Linden and in Loudoun County. The boundaries between the two rocks are complex, for the tongues vary greatly in thickness-from a few inches up to 2 or 3 miles, and the boundary line can not be delineated with accuracy.

\section{FRONT ROYAL DISTRICT.}

South of Linden, which lies east of Front Royal and 76 miles from Washington, on the Manassas branch of the Southern Railway, a large tract of land shows outcrops and loose masses or copper "float."

In the early part of the century the occurrence of copper at this place was well known, and shallow pits were sunk at several places, but no shipments were made until 1861, when 35 tons were collected from the surface and from a 50 -foot shaft which was sunk at that time. This ore was, it is said, shipped abroad.

DEPOSITS NEAR LINDEN.

Near the grist mill south of Linden a mass of altered granite, forming so-called "Silurian shale," adjoins the basic rock and apparently intrudes into it. This is the supposed northeastern extension of the copper "vein." It shows a highly altered basic eruptive carrying seams and stringers of quartz. About one-half mile south from Linden the granite "shale" ends and the ground to the south is strewn with a very dark gray basic rock, which extends to the Sealoch mines and for some miles on either side. It does not form prominent outcrops, but shows as abundant angular bowlder masses scattered over: the fields. Most of the fragments are from 1 to 2 feet in diameter, a few being slightly larger. The outcrops show no pronounced jointing, and the rock is massive and without appreciable schistosity. These characters prevail over the entire area except in the immediate vicinity of the Sealoch copper mines, where the basaltic rock is jointed and to the west of which the rock shows wellmarked schistosity.

S1777 ${ }^{\circ}-$ Bull. $455-11-7$ 
Copper float can be traced up the hillside along a line running approximately southeast and northwest, and it was supposed that this marked a lode extending for 6 or 7 miles. Furthermore, the float on the summit of the ridge indicated three parallel veins. However, examination has convinced me that no such definite and persistent veins exist; that the copper occurs along lines of jointing or of schistose movements; and that the rich copper ore found is a product of concentration by surface waters from disseminated particles of chalcopyrite present in the original rock. The ore is more abundant in the upper zone, because there the movement which produced the joints and the schistosity formed open spaces, which have been filled with quartz and ore.

In one shaft the rock is closely sheeted, the planes being from 6 inches to 1.5 feet apart and the fractures running southeast. Another system of fractures, younger and more widely spaced, crosses the first set at an angle of about $60^{\circ}$, running southwest. One of these later fractures forms the east wall of the Phillips shaft, and it was along this that the greater part of the ore taken out was found. Another less-defined system of fractures dips about $20^{\circ}$ S., instead of $80^{\circ}$ or $90^{\circ}$ W., as do the others. At a depth of 30 feet the shaft encounters a clay seam lying on one of the flat fractures and clearly connected with a vertical fracture, down which waters had percolated. This clay seam thins on the north to a few inches and widens on the south to 2 or 3 feet. It is underlain by very solid blue rock and may possibly mark a fault along which.the ore body has slipped to the south. No ore whatever has been found beneath this clay and none immediately above it.

SEALOCH MINE.

The old Sealoch shaft, $i_{2}^{\frac{1}{2}}$ miles farther west, showed much of the blue "trap" rock on the dump. The shaft was driven at an inclination of about $70^{\circ} \mathrm{S}$. and is said to have yielded some good ore. The outcrops in the immediate vicinity form very rugged ledges farther down the mountain side and clearly do not belong to the hypothetical lode on which the shaft is located. At Cottam Rock, one of these outcrops, the ore is irregularly bunched and seems to occur more especially where the vertical fractures are bent over to the north, showing a minute puckering or overfolding of the schist. A few blasts have been made on these outcrops but no well-defined vein was seen.

The ore so far taken out of the mine workings consists chiefly of native copper and cuprite, with small amounts of malachite and, very rarely, of azurite. It is always associated with quartz, and the gangue is a bright-green rock which is clearly an alteration of the 
general country rock. In some specimens taken from the shaft this green rock showed scattered minute metallic specks, some of which appear to be chalcopyrite and others cuprite. In the specimens the copper was not connected with any quartz, and it is believed that they represent the original copper-bearing rock that has been leached in the upper part of the workings, permitting the concentration of the copper:

A brief inspection of the new work on the Sealoch property, lying east of High Knob Peak, was made in July, 1904. A tunnel 200 feet long has been driven into the hillside to cut the vein on which the Solomon shaft was driven. No ore was seen in this crosscut tunnel, but some quartz in very hard epidotized basalt was found at the faces. There is as yet no evidence to show that the copper ores extend down more than 50 feet or so below the surface. Professor Phillips's shaft was, it is said, sunk to a depth of 80 feet, but although the fractures continued downward, they were local, nonpersistent joints in blocky diabase and carried no ore.

\section{DICKEYS RIDGE DISTRICT.}

Dickeys Ridge is a high outlier of the Blue Ridge proper, lying west of the main divide. It is composed of the same dark-colored basaltic rock as the main ridge, and is intruded at the south end by a coarse-grained granitoid rock, whose weathered forms are light colored, but whose unaltered material is dark gray. When examined in thin section under the microscope it is seen to be a syenite similar to that found at various points along the western slope of the Blue Ridge as far as the vicinity of Elkton.

Copper ore is not uniformly distributed over the mountain, but occurs in only a.few localities, at which more or less work has been done to determine the size and character of the deposits.

\section{MILLS PROPERT' (COVE FARM).}

The Mills property (Cove farm) lies about 8 miles from Front Royal, on the west side of the mountain. The rock is a dense basalt, showing wide sheeting and occasional vesicles. Copper staining occurs only where the sheeting is close: A copper-bearing outcrop of epidotic rock, forming a ledge 50 feet long and 20 feet wide, located about 200 feet below the summit of the mountain, led to the mining work. The rocks constitute no well-defined vein, but show prominent jointing, or, rather, sheeting, that runs N. $50^{\circ}$ E. The deposit has been opened by a cut about 7 feet wide and 35 feet long, extending back into the hillside and encountering the copper-bearing rock. The copper ore near the surface was confined to the epidotized material and showed some native copper, with carbonates, chrysocolla, and lower down, a little bornite. The only semblance of a vein is the 
epidote band, a layer of dense pistachio-green rock 2 feet thick. On the hanging-wall side minute specks of bornite are shown in the dense blue basaltic rock. There can be no doubt about the cupriferous nature of the descending waters, for they have stained both the flat joints and the sheeting planes with carbonates and oxide of copper and have produced scattered spots up to an inch in diameter in the epidotized rock and to some extent along veinlets in the bluish trap, in which bornite is found associated with quartz and massively crystalline epidote. That the bornite was deposited by the descending waters is shown by its occurrence near the bottom of the cut, whose face is about 15 feet below the hillside at its rear. Epidote occurs in veinlets cutting the fresh rock, but in the main vein of the mine it grades into normal basalt; where there are joints its boundaries vary from one to another without apparent reason and without any cross joints.

The smaller joints of the rock are not persistent. The larger joint, which forms the east wall of the cut and is exposed for about 26 feet, shows an iron-stained coating of honeycomb and cellular quartz, which evidently represents the partial filling of a more or less open fissure.

RUDACILL PROPERTY.

At the time of my examination in August, 1905, the Rudacill property was being worked by the Virginia and Pittsburg Copper Company. The company has made openings at two points on the south end of Dickeys Ridge; the first is on the west side of the ridge, near the summit, where some shallow openings have been put down, and a couple of cabins erected. More recent workings are in the cove southeast of the end of the ridge, at a point about halfway up the slope. The first opening is a cut about 75 feet long, in which the usual basaltic rock is exposed, with more or less epidotization running north and south. Well-marked fractures occur at right angles to this, but do not cross the epidote band. The rocks do not show the strong persistent jointing observed in the other property, and there is no sign of a true vein. The ore examined is mainly a staining by carbonates and possibly by bornite upon the joint surfaces. It is said that considerable carbonate and native ore were taken out from the uppermost portion of the working.

The latest working is being carried on at a point about 100 yards from the open cut just mentioned. At this point jointed rock showing carbonate stains is exposed in the walls of a cut, about 18 feet across, in which a shaft about 20 feet deep has been sunk. The material on the dump showed some red oxide of copper and considerable carbonate coating on the joint surfaces. If the ore dump is any indication of the rock exposed in the bottom of the shaft, the opening 
shows no vein nor any pay ore in depth. The shaft is being worked with a hand winze and tub, and is closely timbered. The bottom of the shaft was not inspected, but the material last brought out, still wet from mine water, was on the dump, and was carefully examined.

The rocks are of the Catoctin type, and present no unusual features.

BENTONVILLE-OVERALL DISTRICT.

The Bentonville-Overall district is located 12 to 15 miles south of Front Royal, south of Bentonville, a station on the Norfolk and Western Railway, where some of the earliest prospecting for copper in the Blue Ridge region was carried on. After 1890 considerable .work was done on a number of properties in this district, but in 1905 all operations had ceased, except some prospecting work on a small scale by Front Royal parties on the so-called Empire vein, on the summit of the ridge known as Matthews Arm, near the Page-Warren county line.

At the time of visit the shaft on this property was nearly filled with water. It is reported to have reached a depth of 90 feet before work was stopped in 1904. An inspection of the material on the dump showed it to consist essentially of malachite, azurite with some bornite, and quartz, calcite, serpentine, asbestos, and pink feldspar, in an epidotic phase of the basalt. Within a radius of a few hundred yards a few holes in the rock have been blasted out, in every case the local richness in malachite along the joint planes serving as a motive. None of this material, however, would average more than 1 or 2 per cent.

A second and older shaft is situated lower down on the ridge toward the southwest, on the land of F. C. Hartley. This is an old opening, worked about thirty years ago. The country rock is the common basalt altered and epidotized, the copper-bearing minerals being azurite and malachite in small amount.

- Many surface indications of copper are seen in this general region, as on the Overall estate and the J. M. Matthew's heirs estate. Universally the country rock is the altered and epidotic basalt and the associated minerals are quartz, serpentine, asbestos, and some calcite.

\section{RAPPAHANNOCK COUNTY.}

AMRLER PROPERTY.

Across the mountain, on the west slope of the Blue Ridge, but only a couple of miles from the High Knob and the Sealoch copper properties, two small openings have been made on a fine exposure of copper ore in a rocky ledge known as Cottam Rock, on the property. of ${ }^{\circ}$ R. C. Ambler. A shaft, reported to be, 40 feet deep, has been 
sunk on the north end of the property at a considerable distance below the ridge crest. An examination of the dumps showed epidotic basalt, with some bornite and native copper and considerable malachite staining in places. An open cut and tunnel on the north end of this tract showed similar rock.

MANASSAS GAP COPPER MINE.

On the slope not far below the Ambler shaft and again, farther down, near the deeply cut course of the little stream forming the head of Rappahannock River, are the openings that were made by the Carter Company, subsequently reorganized as the Manassas. Gap Copper Company.

The property was visited in July, 1904, and again in August, 1905. It is most readily accessible from Front Royal, from which place a good and well-graded wagon road to Flint Creek and Washington passes within a half mile of the property. A branch road leads from the main country road down to the little stream which forms the head of Rappahannock River. A private bridge across this stream and a rough-wagon road from the creek one-quarter mile up the gorge leads to the lower tunnel of the company's workings.

The rocks from Front Royal to the mine all appear to be of similar character and to be part of the basaltic mass forming the mountains. The rocks vary, however, very considerably in texture, in color, and in general physical character. In part they are typical basaltic rocks, very dense and of dark-blue color when fresh; in part they are vesicular and resemble recent basalts in texture though not in color. In some places they are columnar and form high ledges along the sides of Happy Creek, which has cut a deep gorge through the rocks. In addition to these varieties there are, in a number of places, areas of what appear to be shales or slates, but which when the surface material is penetrated show exposures of sheared and slaty types. The only other rock seen is a coarse, well-cemented Cambrian sand- . stone or quartzite, whose grains vary from a millimeter up to a centimeter in diameter. This rock is exposed on the slopes south of the company's property and is said to mantle the south slope of the high mountain lying next south of High Point.

The property is opened at four different localities. That known as No. 3 is nearest to the shop and shows a tunnel, 45 feet long, with a course of $\mathrm{S} .70^{\circ} \mathrm{E}$., driven into the blocky, hard, unsheared basalt underlying the soft and crushed surface material. Only about 10 feet of the work nearest the face is in the solid rock. The tunnel represents about three weeks' work, and copper is said to have come from the bottom at the face, but no trace of it could be seen. It was started with the intention of draining the hillside and connecting 
with the No. 3 shaft, but it does not do so, for the shaft is only 8 feet deep, its collar being about 20 feet above the tunnel. An 8-foot drift runs off from the corner of the shaft. No ore could be found in the bottom, but there is a flat seam of quartz and asbestiform serpentine 2 inches thick, with a dip of $10^{\circ}$ and a course about N. $70^{\circ} \mathrm{W}$.

No. 1 shaft and drift is about 100 or more feet above No. 3. It is estimated to go 14 feet below the floor of the open cut which gives access to it, and 30 feet below the old surface of the ground. From its bottom a drift runs in a general southerly direction for 15 feet and then turns eastward. The total length of work on this level is about 56 feet. Good ore is said to have been found, and the dump heap substantiates the statement, but it occurs in small bunches and seams, scattered along the joint planes, and no pay ore could be mined from the present faces.

No. 2 tunnel and shaft are northeast of No. 3 and about 100 feet above it. The shaft is 60 feet deep but is filled with water. The ore dump at the month of the shaft shows the basalt to be altered and apidotized, with flat lenticular strain cracks filled with serpentine and with quartz, and the intermediate rock to be dotted with tiny specks and globules of cuprite. In the lower part of the shaft this cuprite is replaced by chalcopyrite and bornite, forming films along joint planes and scattered in dots through the rock. This sulphide ore is the first noted and it is unquestionably of secondary origin.

The tunnel is 190 feet long and trends S. $65^{\circ} \mathrm{E}$. The face shows loose, shelly, decomposed basalt, with a floor of hard, dense basalt. Throughout, the rock shows close fracturing, the fractures dipping $30^{\circ}$ toward the face, and running $90^{\circ}$, or nearly so. to the course of the tunnel. Careful inspection of both the surface and of the tunnel failed to reveal any vein structure or any well-marked plane of sheeting or shearing.

No ore was seen in the tunnel. The rock from the shaft, however: included a good deal of what might be classed as low-grade copper ore. In general', the rock which carries the copper is fractured by minute veinlets of faulted quartz faulting other veinlets of serpentine. All the veinlets, however, appear to be nonpersistent and of local origin. The caretaker at the mine, who once worked in the shaft, assured the writer that throughout the 60 feet of depth there was no place in the shaft at which one could not find specks of copper-not pay ore, but enough to show that the copper went down.

About 650 feet higher, at the base of the steep and wooded portion of the mountain and not far from the craggy exposure known as Cottam Rock, an open cut (No. 5), about 25 feet long and about 8 feet deep, has been made in the hillside at right angles to the course of the mountain. The face of this cut discloses the upper portion of a pyramidal exposure of basalt capped on both sides by the red- 
dish clays formed by its decomposition. Some good specimens of ore have been taken out, but the only ore now in sight lies along flat fractures, and is a bunch unconnected with any system of sheeting or vein structure-apparently a mere segregation formed by the alteration of the basalt. Bunches of tourmaline, quartz, and calcite also occur, and are equally localized. In the rear of this open cut a layer about 10 inches wide was pointed out to the writer as a vein. It appears to be a somewhat schistose portion, the course of whose fracture is $\mathrm{N} .5^{\circ} \mathrm{E}$. and whose joints dip at $58^{\circ} \mathrm{E}$. The joint fractures show malachite, and the rock itself contains disseminated particles of cuprite. The rock near by contains quartz, calcite, and a little native copper oxide.

The sandstone or quartzite outcrop was also visited. This lies about one-fourth mile south of the No. 5 open cut, beneath a line of springs which outcrop in the hillside. It is unquestionably a part of a continuous mass of sandstone lying quite near the contact with the basalt. It is a true quartzite, but the constituent grains are readily recognizable. At the outcrop this rock is somewhat sheeted by irregularly spaced fractures; the lesser fractures are epidotized for a few inches below the surface and the adjacent rock carries specks of copper oxide. No special significance can be attached to the presence of copper in this rock, save that it is due to circulating solutions which leached the material out of the basalt and carried it along the surface to seep down into the quartzite.

\section{PAGE COUNTY.}

GEOLOGY.

The copper properties in Page County lie on the flanks of the Blue Ridge southeast of Stanley, both east and west of the summit of the ridge, which here forms the dividing line between Page and Madison counties. The district has long been known as showing some of the most promising outcrops of copper ores in the Blue Ridge region, and the developments near Ida, on the headwaters of Hawksbill Creek, and in Dark Hollow, on the headwaters of Robertson River, are more extensive than those in any other part of the Blue Ridge.

The rocks at these localities comprise the same basaltic type which predominates generally throughout the Blue Ridge in Virginia, but include also intrusive masses of syenite and of granite, with interesting alteration products. According to Phalen the basaltic rock is properly classed as an olivine basalt, varying to a metadiabase. Its relations to syenite (hypersthene-akerite) seem to show that it is of earlier age, as it shows a zone of baking and alteration with a variety of structure near the contact. On the other hand, the 
granite to the west appears to be of earlier age, as the basalt has produced metamorphism of the rock along the border and the massive granite is gneissoid. In its habit the basalt presents the usual characteristics observed in these rocks. Owing to its resistance to erosion it usually forms the highest summits and indeed preserves the height of the ridges on which it lies. North of Milam Gap columnar jointing is well developed in the cliffs, which, unlike the basaltic rock near Front Royal, appear to be of intrusive and not of volcanic origin.

Mineralogically the rock shows olivine in visible crystals up to 3 or $4 \mathrm{~mm}$. in diameter, but the olivine is corroded and only the nucleus is fresh. More commonly the olivine has disappeared, leaving a brownish-red mass to mark its former presence. The rock consists of feldspar and pyroxene, with accessory magnetite, chlorite, epidote, and iron ore. Although classed as a basalt, its almost complete alteration would make it a metabasalt, as the groundmass is altered and no longer returnable. Epidote and chlorite are abundant and, in fact, the entire rock has been more or less epidotized, and transitions occur to an epidosite.

East of the summit the syenite; which is technically a hypersthene akerite, forms the lower slopes of the drainage basin of Hawksbill Creek. This rock is very coarse grained and of a dark grayish green. It consists of feldspar, black pyroxene, and an occasional particle of clear quartz. The feldspar is largely orthoclase, but albite occurs both in recognizable anhedra and in a denser portion. Thin sections show orthoclase, plagioclase, hypersthene, diallage, quartz, microcline, iron ore, apatite, and zircon, with the decomposition products epidote, chlorite, sericite, and secondary iron oxide. Hornblende is present in some places, but is not abundant. The minerals form a mosaic whose most abundant constituent is feldspar, which shows evidences of strain in wavy extinction and bent albite cleavage.

Near the copper mines an interesting alteration of the syenitic rock occurs, resulting in the production of an extremely beautiful rock composed of old rose-colored feldspar and green epidote. The peculiar pistachio-green of the epidote together with the old rose hues of the feldspar make a product which is sufficiently handsome to justify its use in interior decoration. The alteration evidently consists of an epidotization of the syenite (hypersthene-akerite), by which the invading solutions, presumably surface waters, have decomposed the pyroxenes and have attacked and replaced the feldspar by epidote. When the process is carried to an extreme point the feldspar disappears, and only epidote and quartz remain, making a rock known as epidosite.

The copper ores occur near the contact between the acidic and the basic rocks and are clearly connected, with a marked epidotization of the rockss. 
MINE NEAR IDA.

The deepest and most extensive copper workings of the Blue Ridge region are those of the Virginia Consolidated Copper Company, near Ida, in the foothill region east of Blue Ridge Mountain, about 5 miles southeast of Luray. Mining was carried on at this locality for about three years, but operations ceased at the end of 1904, after about $\$ 40,000$ had been expended in underground work and surface improvements.

The mine workings comprise an inclined shaft 308 feet deep, with drifts at 80,120, and 280 feet below the surface. The upper level extends for 60 feet to the east; the second has been driven for 170 feet west; and the third is 150 feet long.

These workings show that the basaltic rock is traversed by zones of sheeting in which the fissured and more or less crushed rock is decomposed and soft, and in which surface waters have worked downward to the lowest level of the mine. In these zones films and specks of oxidized ores occur in decreasing amount downward.

These zones of 'close jointing, like the most prominent joint system of the surface rocks, run N. $4^{\circ}$ to $25^{\circ} \mathrm{E}$., parallel with the axis of the hill on which the mine is situated. In the mine workings several such zones are cut; they are readily recognizable, as the rock is softer and is distinguished by the presence of quartz. On the 120 -foot level three such zones were examined, varying from 3 to 6 feet in width. The dip is vertical or steeply southeast. The course of the three zones, as determined on the 120 -foot level, is N. $25^{\circ}$ E., N. $15^{\circ}$ E., N. $10^{\circ}$ E. On the 280 -foot level the sheeting in similar zones runs N. $4^{\circ}-5^{\circ} \mathrm{E}$.

At the surface the jointing runs N. $6^{\circ}$ E., dip $24^{\circ} ;$ N. $10^{\circ}$ E., dip $34^{\circ} ;$ N. $24^{\circ}$ E., $\operatorname{dip} 10^{\circ} ;$ N. $40^{\circ}$ E., dip $12^{\circ} ;$ N. $21^{\circ}$ W., dip $43^{\circ}$; N. $30^{\circ}$ W., dip $6^{\circ} ;$ N. $55^{\circ}$ W., dip $28^{\circ} ;$ N. $88^{\circ}$ W., dip $22^{\circ}$. The dominant direction is $\mathrm{N} .5^{\circ}$ to $25^{\circ} \mathrm{E}$., corresponding very nearly to the direction of banding and foliation of the schist at the contact between the dark basalt and light syenite seen on the main road from Stanley to Ida and along the hill. The jointing is inferred to be due to the syenite intrusion, showing the same genetic relation observed art the workings of the Blue Ridge Copper Company.

The ore is confined to the zones of sheeted, softened rock. 'The alteration consists of epidotization and the production of veinlets of quartz. The copper occurs as malachite films and specks and as native copper. At 30 -foot depths a bunch of ore consisting of malachite and azureite, with quartz, serpentine (asbestos) epidote, and jasper, was found, and a few tons shipped. At 120 feet the rock is epidotized along joint planes and quartz veinlets occur, with small amounts of malachite and rare specks of native copper; oxidation is still quite marked, with an abundance of irony clay along the joints. 
At the 280-foot level altered zones similar to that at the 120 -foot level and having the same general direction were observed. Along the edge of one of these zones a small amount of native copper was seen on a joint face. Malachite was also observed on some joint faces. The peculiar brown flinty or felsitic rock seen above was also observed, together with quartz and calcite in limited amount. Though the evidences of surface-water action are plain, naturally they are not so strongly developed as at the 120 -foot level. The drift, however, was wet and water percolated from the roof. No sulphides were seen, and the specimens of native copper were discovered only by careful search. No pay ore exists in the mine.

\section{MADISON COUNTY.}

DARK HOLLOW.

The best developed copper property in Madison County is owned by the Blue Ridge Copper Company, of Chicago. It comprises about 100 acres of land in what is known as Dark Hollow, situated near the head of Robinson River, about a mile southeast of Milams Gap (also known as Fishers Gap), very near the crest of the Blue Ridge, whose summit forms the dividing line between Page and Madison counties. According to statements made by local residents, the copper ores were worked before the war, but had been abandoned for many years before the Blue Ridge Copper Company began operations, about 1902 .

The old or No. 1 shaft, which is located about 250 feet above the confluence of the two main headwater branches of Robinson River, and a small prospect a short distance to the. northwest, were made many years ago. In 1905, when the property was visited, this shaft was filled with water to within 20 feet of its top. Two drifts run at water-level; the one N. $12^{\circ} \mathrm{W}$. for 20 feet and the other for 9 feet in the opposite direction, comprised the only workings.

The new shaft (No. 2) is an incline 42 feet in length, located about 100 feet vertically below the mouth of the old shaft. From its bottom a drift has been run northeast for 40 feet, with the intention of intersecting the copper-bearing zone on which the old shaft was started. Work on this shaft was temporarily suspended at the time of visit, and a third shaft had just been begun northwest of and higher up the hill than shaft No. 1.

From the old shaft (No. 1) a few tons of ore have been removed and shipped. The country rock along the walls of the shaft appear to be sheeted, in places very closely, and along the joint planes the rock has been altered to epidosite, a material composed of epidote and quartz. In some places the rock is completely rotted and crum- 
bles between the fingers. Epidosite is seen along joint planes and also at the workings higher up the hill, at shaft No. 3. The workings of the old shaft disclose no definite vein, the so-called lead being merely a thinly sheeted epidotized basalt. The zone is, moreover, very irregular. In places the altered rock occurs in masses 6 to 8 inches thick. The joints observed in these old workings have the following directions: N. $20^{\circ} \mathrm{W}$., dip $80^{\circ}$, and N. $8^{\circ}$ W., dip $68^{\circ}$. That this is the prevailing direction of the sheeting is easily determined, as the jointing is rather close.

The workings of shaft No. 2 show a belt of irregularly shaly, soft, almost plastic, moist rock running about midway through the drift. Small stringers of quartz are associated with it, and a little malachite was noted in it. Sulphides of copper are reported to have been found in the seam, but none were noted until a portion of the block was blasted down, the material thus secured showing quartz and chalcopyrite in small amount. So far as determinable this zone has a course of N. $44^{\circ} \mathrm{W}$, or at right angles to the drift, whose course is $56^{\circ} \mathrm{E}$. At the face of the drift a mass of vein material composed of quartz and pink feldspar is seen. The workings of shaft No. 2 show practically no ore, and the dump was equally barren of ore-bearing material. The drift was very wet, and hand pumps were employed to keep it clear of water. Evidences of percolating water are everywhere abundant, both in these and other workings, the water following the joint plane.

At shaft No. 3, at which work had just started at time of visit, similar jointing of the rock is disclosed. The steeply dipping joints exposed have the directions S. $50^{\circ}$ W., N. $20^{\circ}$ W., N. $80^{\circ}$ W., N. $84^{\circ}$ E., the last two probably representing a coordinate fracture. A persistent joint with a dip of $40^{\circ}$ has a course of N. $40^{\circ} \mathrm{W}$. As will be observed later, the persistent north-south joint courses are significant in their relation to the eruptive contact.

The copper outcrops lie near the contact of an intrusive mass of syenite with the normal basaltic rock of the Blue Ridge. The Blue Ridge Copper Company workings are quite close to the basaltsyenite contact, shaft No. 2 being not more than a stone's throw away. This syenite body is, however, distinct from the main mass of syenite seen on the western slope of the ridge. No copper ore was found in the syenite, though it has locally undergone epidotization, forming unakite, a granite rock made up of quartz, pink feldspar, and yellowgreen epidote. The ores found at this locality consist of native copper, blue and green carbonates, a little cuprite, and the sulphide noted in depth. The epidotized rocks show quartz, calcite, and asbestiform serpentine; in fact, the association of the latter epidotic material with the ores is quite intimate. It is difficult, however, to establish any definite trend to the epidotized phase of the basalt. 
The syenite mass near Dark Hollow is seen on the path which leads from Milams Gap down to the mine workings. Basalt forms the entire eastern portion of the spur between the headwaters of Robinson River, the basalt-syenite contact running northwest and corresponding in a general way to the trend of the jointing. The occurrence of the copper ore is clearly dependent on the joint planes and appears to be the result of superficial agencies and the downward percolation of surface waters.

\section{HAWKSBILL MOUNTAIN.}

Northeast of Milams Gap, between Hawksbill and Stonyman peaks, some prospecting was done many years ago. A shaft filled with water, but said to be 60 feet deep, was visited. The dump heap showed the same epidotized basalt, with green-stained joint planes, that is found at other localities. To this excavation Professor Rogers's report (see p. 94) seems quite appropriate.

STONYMAN MOUNTAIN.

In the early fifties the copper excitement which led to the prospecting of the Blue Ridge region and to many attempts to work the numerous copper outcrops from Front Royal southward resulted in the opening of a deposit on the summit of Stonyman Peak, which lies east of Luray on the main divide of the Blue Ridge and is the second highest summit of the Blue Ridge Mountains, rising 4,031 feet above sea level.

Stonyman Mountain is composed of a dark trap rock of basaltic character and of varying degrees of crystallization-from diabase to dolerite. This rock varies in texture from amygdaloidal and ashy to very dense. It shows striking outcrops in broad cliffs that appear to mark lava flows. The rock abuts against a hypersthene akerite, varying to a syenite, which forms the plateau and cliffs that lie southwest of the peak. This syenite rock extends to the base of the mountain and appears to be similar in character and composition to the rock found a few miles south, at Milams Gap.

The copper occurs in the basic rock a few hundred yards from its contact with the syenite and is associated with a zone of not especially prominent fracturing. The ores consist of native copper and copper oxide, with films of carbonate, all of which occur in disseminated particles and irregular segregations in zones where the rock has been epidotized and where joints and fractures have been filled by white, glassy quartz. Ore is confined to belts in which the rock has been thoroughly epidotized but is not an invariable accompaniment of epidotization. 
An open cut trending northwest and southeast is 50 to 60 feet long, 30 feet deep at its highest point, and from 10 to 15 feet wide. It has yielded considerable ore, which was carted about a mile to a spring, where furnaces were erected and smelting was attempted. The size of the slag dump at the spring indicates that the attempt was not successful.

Examination of the open cut, which was cleaned out about twenty years ago and shows good exposures, indicates that the copper belt runs at right angles to the more prominent system of jointing in the rock. It has a fairly well-defined but irregular foot wall and dips about $70^{\circ} \mathrm{NE}$. The rock in which the copper occurs is a pale, pistachio-green, dense metabasalt, which shows fracture lines and areas of apparently crushed material in which the fragments have been epidotized. Epidotization has followed along the fracture planes, the latter being in places partly filled by quartz. The quartz joints in the hanging wall are very prominent and sheet the rock, the welldefined fracture planes dipping at $70^{\circ} \mathrm{N}$. These joints come up to the ore zone and can be traced in the foot wall, but are not prominent. The lack of well-defined sheeting, the bunchy character of the ore, and the indefinite character of the mineralization do not compare favorably with the conditions in other deposits of the same general character found farther north.

Copper-bearing rocks undoubtedly occur at a number of places on Stonyman Mountain. A second and parallel zone, marked by epidotization and the occurrence of native copper, lies southwest of the one just described; and the cliffs on the west face of the mountain, a few hundred feet below the summit, known as Asbestos Cliffs, show disseminated native copper and copper oxide. These cliffs, which are about 50 feet high, are cut in the center by a rift corresponding to a line of rather close sheeting, with plates some 3 to 6 inches wide; the adjacent rock is platy and columnar, the sheets being from 1 to 3 feet thick. No vein is exposed at this place, but the zone of close sheeting corresponds to the epidotization with which the copper is associated. . No development work has been done at this place, though a road has been graded around the side of the mountain to afford access to the cliff.

The permanent water level must be near the valley bottom, for there are no good wells on the hill, hence the water in the mine must be surface water, and the relatively great depth to which it has penetrated is in part due to the elevation of the hill above the surrounding base-level of the country. This penetration has been greatly facilitated by the highly jointed character of the basalt.

Figure 24 is a drawing from a small hand specimen of asbestiform amphibole admixed with some quartz containing particles of 
native copper. The specimen was taken from the dumps examined in August, 1905.

\section{GREENE COUNTY.}

The Blue Ridge region of Greene County containe several copper prospects, two of which have been opened up by mining operations.

HIGHTOP MOUNTAIN PROPERTY.

The most extensive work is that of the Hightop Copper Company, whose mines are situated 7 miles east of Elkton, on the summit and southern side of the southeast spur of Hightop Mountain, at an elevation of 3,000 feet above seal level. The property is accessible by country road to Powell Gap, and thence by private road along the summit, the distance from Elkton by this route being 12 miles. The distance by the short-cut road down the mountain is but 7 miles, but the grade is steep and the road bad.

Hightop Peak is the highest point in the county and dominates the Blue Ridge for many miles about. Its summit is rounded, timber covered, and rearhes an elevation of 3,650 feet above the sea. The streams on both sides cut well back toward the summit, but those on the east have notably deepcut and steep-sided narrow ravines and are eroding much

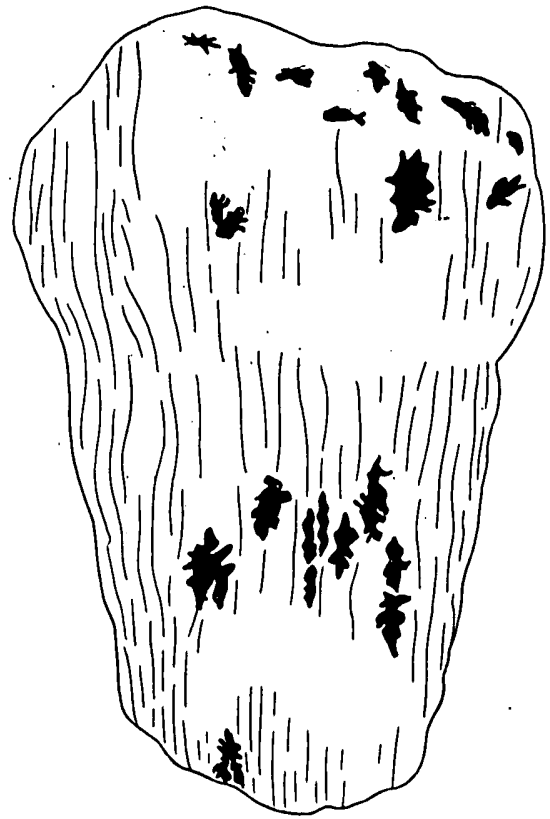

Ficine 24.-Asbestiform serpentine with native copper. Solid black represents native copper. From mine 7 miles southeast of Luray, Page County, Va. faster than those of the Shenandoah drainage. The Blue Ridge summit in this vicinity has many clearings and small farms.

The rocks in the vicinity of Hightop are similar to those farther north, near Hawksbill Head. The isolated mountains at the west base of the Blue Ridge consist of lustrous gray sericitic schists. The foot slopes of the main ridge are composed chiefly of altered basaltic rocks. The slopes to Powell Gap consist of a coarsely granular, syenitic rock, whose appearance corresponds in every way to that of the hypersthene akerite of the Stonyman and Hawksbill region. This rock extends a few rods north of Powell Gap, where it is replaced by basalt; the massive form of the Catoctin schist. The latter 
rock prevails northward from near Powell Gap nearly to the summit of Hightop. In the vicinity of the mines it forms steep and extensive cliffs, from 50 to 75 feet in height, which mark the upper limits of old lava flows. Good exposures were not found along the contact between the syenite and the basalt, so that the relations of the two rocks could not be determined at this locality. The rocks of the mountain top are massive and not schistose, but those in the vicinity of the mines are markedly schistose.

All the rocks of the vicinity show hydrometamorphism, and in the vicinity of the ore bodies the rock is considerably epidotized. The exposures indicate that one lava flow succeeded another and that the shaly felsitic material found along the contacts represents the old surface or soil weathered from lower flows before the succeeding ones were laid down. Amygdaloid is common, and some of the upper parts of the flows show scoriaceous and slaggy portions now in part filled by foreign material

The mine workings consist of extensive stripping of the ledges exposed on the mountain side and of a crosscut tunnel 150 feet in length under a shaft said to be sunk 80 feet from the bottom of an open cut driven on the hillside. The westernmost workings show a well-marked joint system trending N. $20^{\circ}$ E. The ore seemed to be associated with a band of schistose rock 18 inches thick lying amid a more massive form of the same material. Streaks and patches of purple felsitic material appear to be kneaded in with the lava as if taken up when the latter flowed over the old surface. Quartz veinlets occur with a peculiar branching and dropping arrangement and are associated with local epidotization and patches of copper-bearing rock. No definite vein could be found, nor was it possible to associate the occurrence of the copper with any particular system of joints.

The ore consisted of native copper in little grains and pellets scattered through a rock of cuprite; some malachite, mainly as a staining along fracture planes; and in some places of a little bornite and less chalcopyrite. In the large open cut which runs into the hillside for a distance of 75 feet, and to a depth at its face of about 40 feet, slight exposures of the rock were seen. At the breast of the open cut a shaft has been sunk for 90 feet, but it was filled with water and inaccessible. In this open cut the master joints run east and west, but are cut across by north and south joints, showing crushed matter, from 1 inch to 2 inches wide. The rocks show an alternation of massive and of schistose forms, the copper occurring in rudely lenticular masses lying between the two more schistose layers. It is associated with quartz, carrying actinolite bunches, and occurs only in connection with epidote. Chalcopyrite and bornite both occur, appearing to form about lenses of quartz and epidote. 
The material from the shaft showed that in depth the epidotization was decreasing and fading out, the material from the bottom showing only actinolite and sericitic schists. The workings at this place showed every gradation from massive, slightly altered basalt to thinly foliated and shaly lustrous schist. The tunnel was examined, but no ore seen, as the walls are closely timbered and lagged. The tunnel enters the hillside at a distance of 400 feet below the summit of the ridge and has been driven for a distance of 111 feet from the entrance. At che time it was examined the face was in solid and massive basaltic rock, showing splintery fracture but no well-defined joint planes. The course of the tunnel is S. $50^{\circ} \mathrm{E}$. The open cut and shaft are 200 feet (by aneroid) below the tunnel and the same distance below the top of the ridge.

The No. 2 opening shows the most instructive exposures seen at the camp. The ledges have been stripped for a distance of 50 feet in width and 125 feet in length at a point about 250 feet below the summit. The ledges above are massive, while below the rock is quite slaty. The ore occurs associated with irregular lenticles varying in size up to 3 to 5 feet. These lenticles are composed of epidote penetrated by quartz veinlets and are incased in a layer of schistose rock from an inch to 2 inches in thickness, the rock beneath being massive and that above beingschistose. The character and occurrence of the quartz veinlets indicate that they are gash veins, produced by the filling of strain cracks, and the casing of schistose material about the lenticles indicates pressure from it on the surrounding rock. The ore occurs here as sparsely disseminated bornite about the quartz veinlets.

PIEDMONT, COPPER COMPANY'S PROPERTY.

The Piedmont Copper Company owns property on the southeast flank of the Blue Ridge, about 8 miles from Elkton, in Greene County. The mine workings and buildings are about 3,000 feet above sea level and 2,000 feet above the valley. The mineral belt descends the mountain toward the southwest and ascends it to the northeast, traversing the mountain top obliquely 500 feet above the mine, and thence gradually descends, reaching the foothills at Conway River, 20 miles from its starting point. ${ }^{a}$

Concerning this property, Prof. Dwight says:

'The Sims property, on the eastern slope of the Blue Ridge, 5 miles north of Stanardsville, the county seat of Greene County, shows the same geological conditions observed near Front Royal. Native copper and cuprite occur in bunches along shear zones in diabase (Catoctin schist). The rock is often schistose and is penetrated by tongues of granite, shaly near the contact. Local segregations and many small lenticular masses of quartz occur along

a Information furnished by G. L. Clarke, from report of Prof. W. B. Dwight, dated Oct. $9,1901$.

$81777^{\circ}-$ Bull. $455-11-8$ 
the shear zone, usually trending across the direction of shearing. The shear zone has a course of S. $80^{\circ} \mathrm{W}$. magnetic, and dips $70^{\circ}$ to $80^{\circ} \mathrm{E}$ : A number of shallow openings have been made along these zones, and on the Sims property a shaft 30 feet deep has been sunk. No well-defined ore body has as yet been seen, though good ore has been found at the surface diggings both at this place and at a locality 2 miles farther west. The amount of development work done does not warrant a positive opinion as to the future of these deposits; but inasmuch as the ore is the result of alteration, and the original source is as yet unknown, there is some doubt as to their future. At the western pit the shear rock shows pyrite and chalcopyrite in smell amounts disseminated through the altered rock. These minerals occur only where quartz and epidote are found, and the small quartz lenticules are often found surrounded by a zone of epidote carrying pyrite. The material from the western opening shows movement and is in part brecciated. A short crosscut, driven 25 feet north at a depth of 30 feet cuts through the curly schists of the shear zone, but shows no ore.

\section{SUMMARY OF BLUE RIDGE ORES.}

Native copper and cuprite ore is found very commonly with epidote schist, not only in the mountain region, but over the Piedmont Plateau. It is evident that the association of epidote (and, to a lesser degree, of chlorite) with native copper is a constant one, for which reason it is believed that the processes incident to the formation of the one led to the formation of the other. Such ores occur near Virgilina, Va., near Charlotte, N. C., and in many scattered localities through the South.

From the detailed descriptions given it may be concluded that the basalt, which is the copper-bearing rock of the Blue Ridge region, has undergone regional alteration, with local epidotization and a further alteration, resulting in the production of quartz and to a less extent of calcite, feldspar, and asbestiform serpentine, with associated native copper, malachite, azurite, cuprite, some bornite, and scant chalcopyrite, and possibly chalcocite, nowhere, however, in commercial quantity.

These alterations, which are local and irregular in occurrence, have given rise to expensive and fruitless prospecting, the amount of copper present being everywhere too small to pay. To apply the term "vein" to such deposits is misleading. It is better to call them local segregations, occurring in altered zones or patches and in some places developed perhaps on a greater scale along a prominent system of close vertical joints in zones of the softer and more altered rock near a syenite contact. "Where the joints are locally concentrated a natural path is afforded for downward-moving superficial waters, which have produced the ore deposits, and it is along such paths that the greatest alteration should be expected. Recalling the uniform nature of the copper deposits and their association with the altered portions of the rock, it is evident that one must look to the zones of sheeting and 
alteration as the normal site of the ores. But when it is borne in mind that there are other joint systems; that the basalt has undergone local alteration, perhaps throughout its mass, besides the regional alteration already mentioned; and when, moreover, it is remembered that the copper has not been introduced by the syenite but exists disseminated throughout the basalt, then the reason why the ore does not appear to be restricted in its distribution to the soft zones near the syenite contact will be understood.

The copper comes from the mass of the basalt, where it probably exists as thinly disseminated chalcopyrite and perhaps as cupriferous pyrite. These minerals have been acted on by percolating waters and have been dissolved, carried, and redeposited with vein materials along the joint planes of the rock, forming small veins and patches or local segregations. Accordingly it should be expected that the richest ore would be found near the surface, for it is in the most superficial belts that the solvent power of atmospheric waters is strongest and that the ore would be found steadily to diminish in depth. Such a condition seems to exist at the mines of the Virginia Consolidated Copper Company; where the alteration has extended to a depth of 280 feet, but where the richest ore is found 30 feet below the suiface.

In the higher and steeper ridges, which rise to considerable elevations above the local stream levels, such a depth of altered zone is not surprising, for in them the level of ground water is relatively deep below the surface. In those areas where the workings are lower down the slopes and therefore nearer local water level the depth of alteration must be necessarily less.

\section{SOUTHWEST VIRGINIA REGION.}

\section{INTTRODUCTION.}

The most noted copper region of Virginia lies in the southwestern part of the State in a belt of crystalline rocks passing through Floyd, Carroll, and Grayson counties. It forms part of the eroded Blue Ridge upland, with well-rounded summits and deeply trenched streams, which is known as the Floyd-Carroll-Grayson plateau. It is traversed by two branches of the Norfolk \& Western Railwaythe Cripple Creek branch running to Galax and the Betty Baker line running to the mine of that name-both of which reach what is commonly known as the Carroll vein or the Great Gossan lead of Virginia.

The region was actively prospected in the early 50's, and the rich secondary copper ores found beneath the gossan were boxed and shipped to Baltimore. From 1852 to 1856 the South had what the journals of that day called a "copper mania," and every outcrop of limonite, large or small, was currently believed to overlie a copper 
mine. During 1854-55 eight mines were producing on the Gossan lead, and the ore shipped for the six months from January 1, 1855, to July 1,1855 , amounted to 2,721 boxes, carrying $1,454,363$ pounds of ore. As this ore averaged about 25 per cent copper and the metal was at that time worth 26 cents per pound, the ores yielded a profit despite the fact that they had to be hauled a long distance to the railroad.

Other mines have been opened on a dike of amphibolite traceable for many miles northwest and southeast through Carroll County, and still others near Floyd, in Floyd County, to the northeast.

\section{GEOLOGY.}

The immediate wall rock of the lead consists of highly lustrous sericite schist. Southeast, on the hanging-wall side of the vein, the rocks are throughout most of the course of the vein ordinary mica schists, more or less replaced by altered fine and coarse grained diorites. The foot-wall rocks appear to belong to a different series, and are, in part at least, similar in lithological character and position to the Ocoee group of the southern Appalachians. No detailed section was made, but it is certain that a belt of greenstones, with intrusive granitoid rocks, lies betwen the quartzites of presumable Cambrian age which flank the mountain region and define it from the Shenandoah Valley, and that these greenstones are relatively massive and represent various types of basic rocks. In some places this greenstone belt extends upward and across strata that resemble the Ocoee group and are found near the gossan lead, but nowhere, so far as observed, do they appear on the hanging-wall side of the vein. These facts and the structure of the vein itself prove faulting, and as the dip of the vein is from $45^{\circ}$ to $60^{\circ}$ there is little reason to doubt that the faulting is of the overthrust type, which predominates in this portion of the Appalachian region. These features are observable practically throughout the entire belt. In the mica schists lying southwest of the vein several narrow basic dikes were observed. They appear to be of later age and of dioritic character.

Along the road from Sylvatus to the Cranberry copper mine shales, presumably Ocoee, form the slopes to the crossing of Little Reed Island Creek, and along this stream and up Bobbitt Creek to the summit. They weather to a yellow soil. Beyond the summit gray shales extend to the turnpike. No igneous rocks were observed.

THE GOSSAN LEAD.

GENERAL CHARACTER.

The gossan lead has been reported by various writers, notably Boyd, to be from 20 to 27 miles long. It is distinctly traceable by an almost continuous gossan outcrop for 18 miles, from New River, near Old- 
town, northeastward to beyond Betty Baker (Sylvatus post office). A large part of its course is covered with a thick forest growth with more or less brush, and since the gossan outcrop rarely projects above the surface and is in some places so covered by soil and vegetation as to be indistinguishable, the absolute continuity of the lead can not be vouched for. But from one end to the other there are old

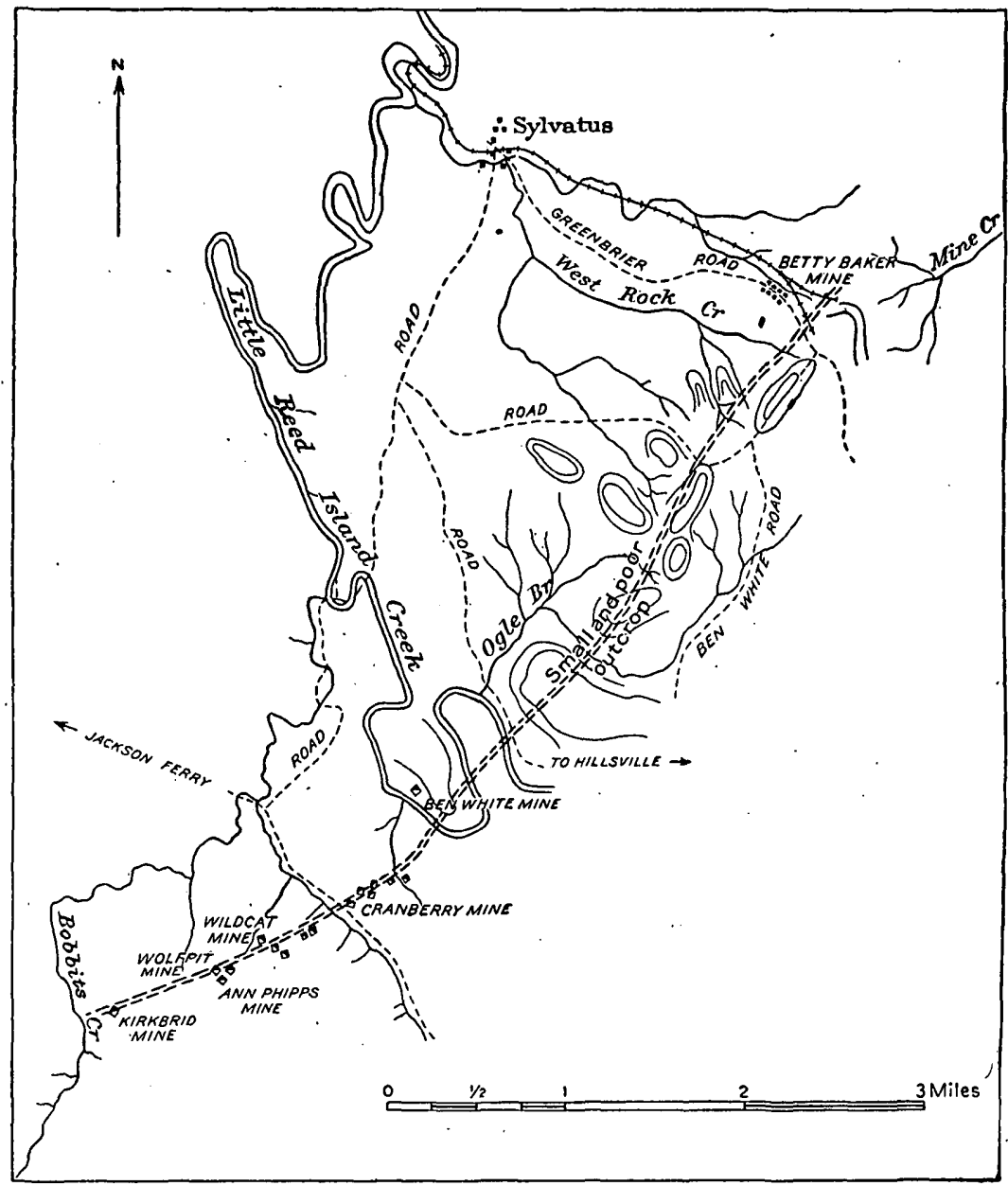

Figure 25.-Mip showing location and course of gossan lead of Virginia.

pits whose dump heaps show typical gossan ore, and as the old mine workings, 20 to 60 feet below the surface, could once be continuously followed underground for miles, there is little doubt that the deposit is one of the greatest, if not the greatest; known in the Appalachians.

The map (fig. 25), which is reproduced by permission of Capt. J. F. McKee, shows the location and course of the gossan lead and the mines scattered along it. 
The surveys made by the Norfolk \& Western Railway engineers for a railroad to reach the limonite gossan of the Carroll vein give a careful location of the vein from the Kirkbride property on the southwest to the Betty Baker property on the northeast. Throughout this distance the vein is large and very well defined and is continuously traceable from the Kirkbride to the Ann Phipps mine, across Wolf Pit Branch and the old pits of the mine of that name, across Wild Cat Branch and its mines, to the Cranberry Meadows, where the remains of an old smelter can still be found. The course is N. $65^{\circ}$ E. to the Cranberry mine; then it changes to N. $40^{\circ} \mathrm{E}$, continuing thus, with slight variations, across Little Reed Island Creek to Ogles Branch, where it changes to N. $20^{\circ}$ E.; running thus to the Baker mine, where it is N. $35^{\circ} \mathrm{E}$. Between Ogle Branch and the Baker mine the vein has small surface showing and but scanty indications are noted along the wooded ridge until the workings of the Baker mine are encountered on the west fork of Rock Creek.

In width the vein varies, as would naturally be expected from a fissure of this character. In places it is said to pinch to 5 feet and in others to widen to perhaps 100 feet. On the Chestnut property it ranges from 45 to 60 feet, and on the Betty Baker property from 20 to 35 feet. The narrowest place found was at No. 7 shaft, about a mile west of the office of the Betty Baker mine, where the vein is squeezed to 5 feet. At the east end of the Betty Baker property the surface shows a width of about 300 feet of limonite. The average thickness of the vein at the Cranberry mine is about 20 feet. Between the Cranberry mine and the Ann Phipps mine the thickness ranges from 12 to 14 feet.

The gossan is much wider than the underlying vein, a familiar phenomenon in the study of veins, as the gossan forming water not only works downward along the walls and spreads out on the country rock on either side, but also forms masses of concretionary ironstone on the surface. At the Cranberry mine the gossan is 135 feet wide along the road, but in part this represents a thin overflow or cap of limonite formed by the surface waters running down the slope.

The strike of the vein varies in accordance with that of the country rock; at the Betty Baker it is N. $35^{\circ} \mathrm{E}$, but it shows many deviations from this when traced southwestward, the strike reaching as much as $\mathrm{N} .60^{\circ} \mathrm{E}$. in some places. The vein has not only suffered from strike faulting, but shows sharp folding or change of strike southwest of the Cranberry mine; at the Betty Baker mine a horizontal displacement of 62 feet was measured close to the point where the wagon road crosses the ledge. The dip varies somewhat, but averages about $45^{\circ}$. Former observers who have examined the Chestnut property speak of the vein as being nearly vertical., A marked dis- 
cordance in the dip of the slates and of the vein was observed in the first ravine southwest of the old mine buildings at the Betty Baker mine. At this point the schists or slates, which are presumably Ocoee, have a dip of about $30^{\circ}$, and the vein cuts across them at an angle of about $45^{\circ}$. The ore shows occasional slickensided surfaces and flat seams crossing the vein. It is evident, therefore, that there has been some postmineral faulting, but the character of the ore and its mineralization indicates clearly that the vein filling occurred subsequent to the metamorphism of the region.

At Little. Reed Island Creek, about one-half mile above Ogles Branch, the gossan lead shows pyrrhotite and chalcopyrite, with balls of schist and of impregnated leafy or nacreous slate. It has a steeper dip than the slate, which dips about $30^{\circ}$. The hanging wall of the slate for about 6 to 8 feet from the vein is native, and then the gneiss shows. The gneiss is a solid and firm rock, and resembles the specimens taken half a mile farther up the creek, which appear to be massive diorite. On the hanging-wall side the leafy schists extend for several hundred feet, and then are replaced by the dark, basic greenstone. The vein is opened by a 10 -foot drift about 50 feet above the creek.

CHARACTER OF THE ORE.

The vein consists essentially of pyrrhotite, with disseminated particles and

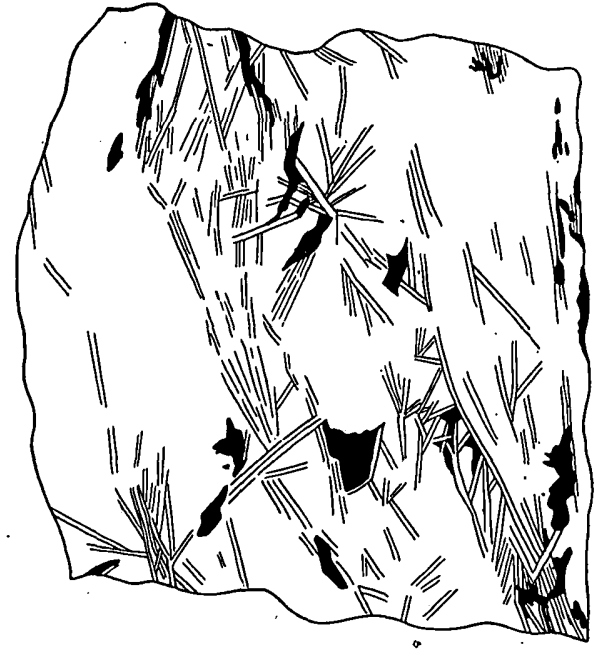

Figure 26.-Ore from Chestnut Yard mine, Cạroll County, Ya. Shows pyrrhotite with columnar hornblende and chalcopyrite. White is pyrrhotite; black is chalcopyrite; lined areas are hornblende. stringers of chalcopyrite. Horses and protecting masses or intercalations of mica schist, or rather of sericite schist, occur in the vein, and in places where the fresh material is observable a considerable proportion of the vein consists of coarse biotite schist impregnated with chalcopyrite and interleaved masses of pyrrhotite. Quartz lenses occur on the wall of the vein, particularly the hanging. wall. Where the walls have been exposed by the -caving of the old: workings it is seen that they are undulatory, and that the lenticular. swelling and thinning of the vein is due to their unevenness. The: slickensides observed are believed to be due to later movement. The vein filling is locally composed of a conglomerate of rock fragments. of varying character, cemented together by. pyrrhotite. In some 
places these fragments are well rounded; in others they are subangular and include rock types not seen on the surface, either at the - vein or near by. The evidence indicates an origin as friction breccia. The occurrence of rounded quartz balls indicates that the vein was formed after the segregation of the quartz veinlets. Inasmuch as the vein filling is solid and massive, showing neither schistosity nor sheeting, though the inclosing rocks are thoroughly altered by regional metamorphism, it is believed that the vein is of much later formation than the inclosing rocks, and was formed after the period of metamorphism, which masked and disguised the original character of the rocks. This evidence confirms the conclusions reached

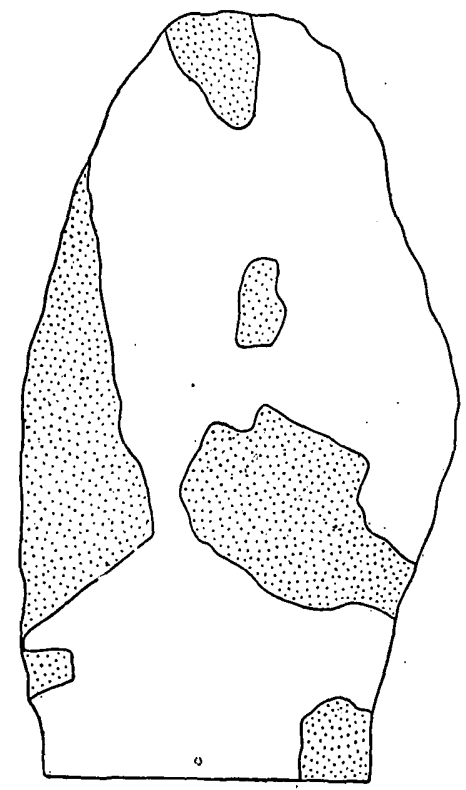

Figure 27.-Fyrrhotite with included quartz fragments. From Betty Baker mine, Carroll County, Va.

from the study of the rocks and of the included fragments.

The structure of the vein is shown in figure 27 , which illustrates a block of rock seen in the ores from the Betty Baker mine. This same brecciated structure was observed in the ores of each locality visited, though nowhere is it so prominent as it is in the Betty Baker ores.

The primary vein filling consists mainly of pyrrhotite, with scant chalcopyrite, but it is not a solid mass of pyrrhotite from wall to wall, but rather a series of layers, partly of pure pyrrhotite, but largely of pyrrhotite mixed with more or less micaceous material, which is an altered form of the country rock (fig. 28). This primary ore is seen exposed at one opening, that of the Pulaski Mining

Company on Chestnut Creek, at the southwest end of the lead. Ore dumps, however, can be seen on the Cranberry property and at the Betty Baker mine at the northeast end of the lead, and the structure of the ore can be studied in the material thus exposed.

The phenomena of secondary enrichment, which proved so marked a feature of these mines and led to their working in the early fifties, may be observed in several recent workings. Beneath the gossan there is usually found from a foot to 6 feet of the secondary copper ores, containing near the top more or less carbonate and oxide and very rarely a little native copper; farther down, on top of the unaltered sulphides, there is more or less soft black ore, the so-called 
"smut ore" of the miners, with secondary chalcopyrite. The character of these secondary ores is shown in the following table, which gives the position of the ores shipped from three of the principal mines in 1856 :

Copper content of secondary ores from mines on the gossan lead (Carroll vein), Carroll Couvity, Va. ${ }^{a}$

[Analyses by Doctor Dickenson, of Philadelphia.]

\begin{tabular}{|c|c|c|c|}
\hline . & $\begin{array}{c}\text { Cranberry } \\
\text { mine. }\end{array}$ & $\begin{array}{l}\text { Kirk- } \\
\text { bride } \\
\text { mine. }\end{array}$ & $\begin{array}{c}\text { Ann } \\
\text { Phipps } \\
\text { mine. }\end{array}$ \\
\hline 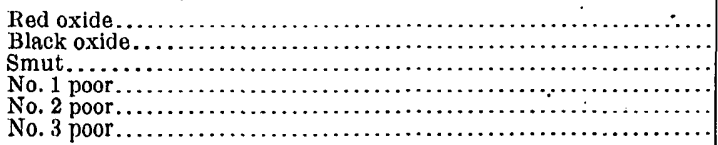 & $\begin{array}{r}61.05 \\
52.10 \\
26.00 \\
9.50 \\
5.00 \\
3.00\end{array}$ & $\begin{array}{r}64.00 \\
52.50 \\
25.60 \\
1.00 \\
3.50\end{array}$ & $\begin{array}{r}66.08 \\
54.20 \\
24.08 \\
7.28 \\
5.00 \\
4.00\end{array}$ \\
\hline
\end{tabular}

a Mining Magazine, vol. 6, 1850, p. 463.

The primary ore contains about 32 per cent of sulphur. The other ingredients are shown in an analysis which was furnished to the

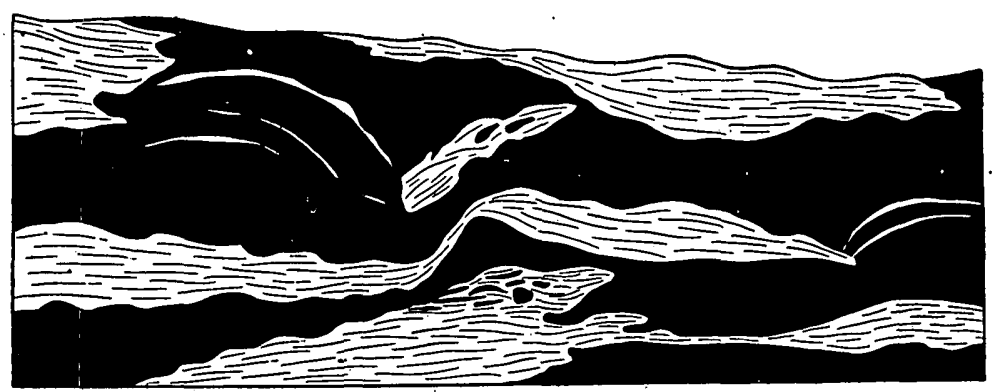

Figure 28.-Pyrrhotite interleaved with talc. From Chestnut Yard mine, Carroll County,

Va. Lined areas are talc; solid blade is pyrrhotite. Two-thirds natural size.

writer by the Pulaski Mining Company but does not represent the composition of a pure pyrrhotite ore, as the material sent to the acid works carries considerable biotite ore, which, of course, raises the magnesia content.

The Cranberry property is said to have been worked for its cupriferous pyrrhotite ores, and copper smelters at both the Betty Baker property and at the Cranberry property ran on ores cobbed out from the pyrrhotite mass. The amount of the copper pyrite becoming scanty as depth was reached, the smelting operations proved unprofitable and were abandoned.

\section{THE MINES.}

FEATURES OF THE VEIN.

As the numerous properties along the lead were worked for copper from 1854 to 1856 and were abandoned before the Civil .War, very 
little information can be obtained about a large part of the vein. The gossan cap, however, has been the basis of extensive operations, its purity and ease of extraction making it a very desirable ore for the local blast furnaces. Figure 29 shows a longitudinal section along the vein and is made from surveys and data compiled by Capt. J. F. McKee. It shows the profile along the course of the vein, the height to which the unaltered sulphides rise, and the depth of the gossan overlying the primary ore.

In general the outcrop is relatively inconspicuous as to height, but is noticeable on account of the dark-reddish or ochrous color of the concretionary ironstone, which is in marked contrast to the surrounding gray soils of the crystalline belt. This gossan extends downward 20 to 60 feet, averaging a greater depth on the hilltops than in the ravines. It has been removed from the Betty Baker property and from the Chestnut Creek property (commonly known as the "Great

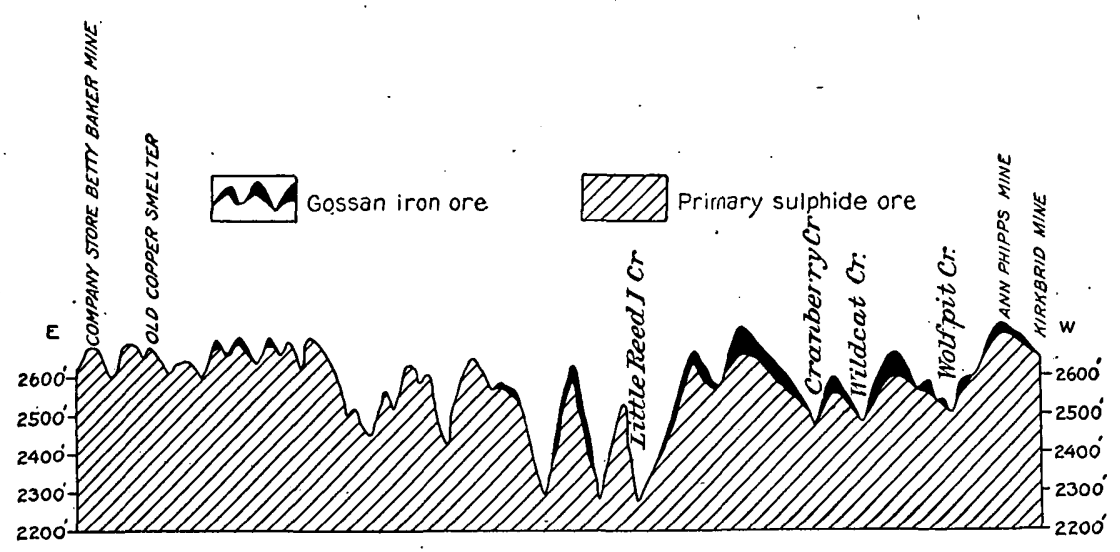

Figure 29.-Longitudinal section along gossan lead, showing capping of iron ore.

Outburst"), but the intervening portion of the vein being remote from the railroad had not been worked for iron ore at the time of visit.

BETTY BAKER MTNE.

Before closing down the Betty Baker mine 1,800 tons of mundic were shipped by Capt. J. F. McKiee to the Southern Chemical Company at Winston Salem, N. C., where it was used in acid making. This was in 1900 . The pyrrhotite ore contained 33 per cent sulphur; after roasting, this material carried 58 per cent iron and was said to be particularly valuable for making crucible steel. The shipments to the Winston-Salem Works were stopped when the plant was absorbed in the consolidation of the Southern fertilizer manufactories.

The ore, if free from mica, carries approximately 55 per cent iron when roasted; but most of it carries biotite and when roasted has 
about only 45 per cent of iron. The raw ore carries about 0.6 per cent manganese, 0.35 per cent copper, and 3 per cent magnesia. Iron furnaces require that the sulphur content shall be below 0.7 per cent, and it is difficult to roast the ore sweet enough for use in such.

CRANBERRY MINE.

The Cranberry mine is situated on the divide between Cranberry Creek and Big Island Creek. The main road from Jackson Ferry to Hillsville passes across its western end.

The mine was opened in the fifties and was worked for nearly ten years, black copper ores being extracted and treated in a smelter erected for the purpose. It was closed down in 1859. The latest work is said to have been done in 1893, when W. C. Moxham obtained an option on the property, cleaned out the old shafts, cut the growth of young trees from the outcrop of the vein, and shipped some sample lots of ore.

The old workings are at present inaccessible, and observations were necessarily confined to surface exposures, to an examination of the ore dumps, and to data supplied by diamond-drill cores, the results of drilling by the Virginia Iron, Coal and Coke Company in 1902. Neither machinery nor buildings remain on the property. Figure 29 shows a profile across the property and indicates the thickness and amount of the heavy gossan capping which has never been removed from the vein and is available as an iron ore.

Samples seen on the dumps show the ore to be a somewhat less pure "mundic" or pyrrhotite than that of the Betty Baker mines. Though some ore carrying 10 per cent or more of copper was encountered, the vein as a whole is evidently low grade. The débris on the dump shown included fragments of country rock, slickensided surfaces, and a mineral association nowise different from that found elsewhere along the vein. The property was formerly worked by the usual method of crosscut tunnels, with long drifts following the - upper limit of sulphide ore and opening through air shafts to the surface at frequent intervals. The wall is plainly seen at one or two points, and has a dip of $45^{\circ} \mathrm{E}$. In the creek bed the Meunir shaft is 104 feet deep, and was worked for yellow copper ore. At the time when the copper smelter was in operation an extensive settlement occurred at this point.

In 1902 a diamond-drill hole was put down by the Virginia, Iron, Coal and Coke Company, under the superintendence of Captain McKee, to a depth of 524 feet vertical in the hanging wall several hundred feet from the outcrop of the vein. This hanging wall is a fibrous quartz schist not at all like the nacreous shales of the footwall. A core from a depth of about 100 feet shows it is a schist. 
WILDCAT MINE.

Across Cranberry Creek to the southwest, at the Wildcat mine, a series of old shafts still open down to the water level, show the direction of the vein to be N. $65^{\circ} \mathrm{E}$. and the dip to be about $45^{\circ}$. In the woods the gossan is hardly noticeable and does not project above the surface. The strike at the crossing of Wildcat Branch is N. $65^{\circ}$ E.

KIRKBRIDE MINE.

Several open cuts expose the vein on the Kirkbride property, southwest of the Wildcat, but the long crosscut tunnels driven from the sidehill to the vein and the drifts driven on the vein are all caved and inaccessible.

VAUGHAN MINE.

The Vaughan mine, which lies southwest of the Kirkbride, has not been worked for many years, but the old shafts are still open, and, although the gossan is hardly noticeable and does not project above the surface, the shafts occur at such frequent intervals that there can be but little doubt of the continuity of the vein. These shafts are said to be 30 to 50 feet deep and to go down to solid sulphide ore. At the Vaughan mine a crosscut tunnel 15 feet long is driven into the hillside to tap the vein. The gneiss here shows considerable crinkling and also a black and dense amphibolite. It is said that the Vaughan workings and those on adjacent properties made a continuous drift 4 miles long. The direction of the vein, as determined by the old shafts, was nearly $65^{\circ}$ E. and the dip $45^{\circ}$, but inasmuch as many of the shafts were sunk in the hanging wall it is impossible to make certain that this direction is correct. The ore from this mine was hauled to Max Meadows and shipped to Baltimore. Most of it was pounded up and put in boxes. According to Mr. H. E. Vaughan, who lives near by, the vein was 75 feet wide in places.

[ VEIN SOUTHWEST OF THE VAUGHAN MINE.

From the Vaughan mine to Crooked Creek no outcrops occur for 5 or 6 miles, or at any rate the vein has never been worked, and its presence not therefore definitely determined. The region is densely wooded as far as Crooked Creek, beyond which, to Iron Ridge, the vein is well exposed and has been extensively worked.

FUTURE OF THE GOSSAN IEAD,

So far as known from mining operations, the amount of chalcopyrite becomes scanty in depth. In recent attempts to mine the ore the percentage of copper in the output was reckoned at 0.6 to 1 per 
cent, a percentage that will not permit the working of the vein for copper alone. The future value of the "gossan lead" apparently lies mainly in its unworked iron ores and in the utilization of the magnetic pyrite for acid making. There is reasonable probability, however, that ore shoots carrying 3 to 6 per cent copper may be found when the vein is further developed. The fact that all parts of the "gossan lead" are cupriferous, as shown by the early blackcopper workings and by the primary sulphide ores that have been opened up, makes it not at all improbable that in its known extent of 18 miles there are places where it is locally above the average in copper content. Moreover, the development of the primary sulphide ore has been confined to only three places-the Betty Baker, the Cranberry, and the Chestnut Ridge mines.

In mining the gre much vein filling of black biotite mica rock is extracted, and this is apparently richer in copper than the solid pyrrhotite. It is possible that such ores can be culled and shipped for copper treatment, and, of course, it is also possible that the roasted cinder may be economically leached for copper and its metallic contents precipitated for scrap iron.

The utilization of the ores for acid making has been attempted by the Pulaski Mining Company, which has built an experimental plant at Pulaski and in 1905 was turning out high-grade 95 per cent acid. The officers of this company would not divulge the secrets of their plant and process, but it was generally believed that the process was still in the experimental stage and that. ultimate success depended on the practical elimination of the sulphur from the ore and the utilization of the cinder for iron manufacture. At present (1906) no especial encouragement can be given to others to attempt to solve this problem, as it is one demanding the highest chemical and technical skill and abundant capital.

TONCRAY DEPOSI'T.

The Toncray deposit, located at the northern end of the copper belt, about 7 miles from Floyd, is similar in character to the deposits of the gossan lead. The ore consists of chalcopyrite with pyrrhotite and pyrite impregnating amphibolite or forming a mass of solid sulphides. The vein is said to be about 30 feet wide, runs N. $25-54^{\circ} \mathrm{E}$., and dips southeast at an angle of $30-45^{\circ}$, crossing the steeper dipping bands of schist. The property is developed by two old tunnels (vertical), 70 feet apart, which were recently cleared out and extended a few feet, and by a new shaft. The old drift showed solid pyrrhotite ore 10 feet below the surface. The ore is low grade, and owing to the abundance of hornblende magnetic concentration or 
direct smelting are the most hopeful methods of treatment. The old adit-a train tunnel-shows a flow of water that deposits terraces of iron ocher. These openings are west of the "branch" or stream and west of the road.

The shaft is 100 feet deep, cutting the footwall of the vein with a 39-foot crosscut through the ore. A drift 15 feet long is driven west on the footwall and a 50-foot incline follows down on the footwall. The workings show 10 feet of coarse biotitic gneiss on the footwall, and some of the same rock, together with granular quartz, lies scattered through the vein. The "mica ore" shades into a "giant gneiss," carrying ore.

The property was formerly worked on a small scale for the limonite of the gossan. It is said that the course of the vein can be traced for: several miles by this limonite outcrop, exposed every half mile or so where it is cut across by ravines.

\section{AMPHIBOLITE DIKE.}

Besides the gossan leads mentioned, there is a dike of amphibolite, traceable for many miles across the country, whose weathered outcrop shows occasional masses of native copper and which, for this reason, has been often called the "native vein." The trend is northwest and southeast, and the dike crosses the foliation planes of the schists. $^{a}$ The only attempt to work it is on the Gardner and the Goad properties, both of which have been opened up by shafts and tunnels.

Schist is well exposed in the creek bed near the Goad mine; it strikes N. $50^{\circ} \mathrm{E}$. and dips $61^{\circ} \mathrm{S}$; the dike crosses this at an acute angle. It is also well exposed 50 feet south of the engine house, the strike there being $\mathrm{N}$. $65^{\circ} \mathrm{E}$. and the dip $60^{\circ} \mathrm{S}$. These dips were taken on extremely good exposure of the fissile rock in the open-cut work south of the shaft house.

The ore occurs in a dark and coarse-grained amphibolite dike about 15 feet wide, which is well exposed in the walls back of the excavation made for the engine house. The exact trend of the dike could not be determined, but it apparently cuts the schists at an angle of about $20^{\circ}$. The ore occurs as round nodules about the size of a hickory nut, composed of chalcopyrite. Postmineral movement has squeezed these out into pyrite mirrors and streaks, giving the impression of very much richer ore than the facts warrant. The Goad shaft is 3 feet 4 inches by 4 feet 2 inches in the clear and is timbered and planked and in good condition. It is, however, filled with water to

${ }^{a}$ Boyd, C. R., Mineral resources of southwestern Virginia : Trans. Am. Inst. Min. Eng., vol. 8,1880, p. 342 . 
the tunnel level, which is about 15 feet below the collar. The country rock through which the dike cuts consists of black mica schists, breaking into slabs one-half inch to an inch thick, and alternating with leafy sericite schists carrying interlaminated films of quartz. The ore at both the Goad openings shows the same curly or crinkly contorted amphibolite, carrying pyrite balls and characterized by slickensides and sheared surfaces. It is, however, somewhat more varied than that at the Gardner mine, showing acidic material and sometimes bands of dense and evenly foliated black amphibolite, with an abindant dissemination of pyrite.

The Gardner and the Goad properties are held under option by the Virginia Copper Company, and were once extensively advertised. Observations show that the richness and amount of ore already extracted is not in accord with the published statements and that the nature of the deposit has been misunderstood. The dump heap consists mainly of knotty and curly sericitic schist. The Goad Tunnel, said to be 201 feet long, was flooded at the time of visit, and of course the shaft, which lies 40 feet from the mouth of the tunnel, was also full of water, so that inspection of underground workings was impossible. The rocks near the ore-bearing layers appear to be somewhat more amphibolic than elsewhere.

The deposit can not be classed with those of the gossan lead nor with those of the Ducktown type. It is clearly a dike in the normal schist series, in which copper pyrite balls have been formed and by subsequent movement have been drawn out into small irregular masses. No definite ore body was seen, unless one calls the dike carrying these chalcopyrite balls an ore body. The property is well situated with regard to water, roads, and timber, but the results of the development work so far done have been unsatisfactory and it is generally understood that the property has been abandoned.

\section{NORTH CAROLINA.}

\section{CHARACTER AND EXPLOITATION OF THE DEPOSITS.}

The amount of copper produced at present in North Carolina is small and comes mainly from the Gold Hill and Virgilina districts, $y$ et the State contains a large number of copper deposits of wide diversity of character apparently offering conditions permitting profitable working. Many of the veins of the gold belt contain copper ores; but the successful operation of such properties depends on the presence of large amounts of ore, and none of them have as yet become important producers.

The deposit in Ashe County, in the northwestern part of the State, differs materially from the deposits of the gold belt, consist- 
ing of low-grade pyritic ores of the same general character as the well-known Ducktown, Tenn., deposits. These ores constitute the. so-called copper range, a misleading name, since the known copper deposits of this section of the State show the same variety as those in the region east of the mountains.

The copper-bearing quartz veins of the Virgilina district, which lies partly in V.irginia and partly in North Carolina, have been extensively developed in recent years and several properties have become intermittent producers. In the western, mountainous part of the State there are three districts; the first, that of Ashe and Alleghany counties in the extreme northwestern part of the State; the second, that of Jackson and Macon counties in the southwestern part; and the third, that of Rowan and Davidson counties in the western Piedmont region. The first of these contains the Ore Knob mine, so profitably worked for many years. 'The deposits of the Virgilina district have already been described (see.pp. 67-89); a description of those of the other districts follows.

\section{ASHE AND ALLEGHANY COUNTIES.}

ORE KNOB MINE.

Location.-The Ore Knob copper property is situated in Alleghany County, in the extreme western part of North Carolina, on the flat top of one of the higher spurs of the Blue Ridge, at an elevation of 3,200 feet above sea level. The nearest railroad point is Galax, Va., the terminus of a branch line of the Norfolk \& Western from Pulaski, Va.

Geology.-The geology of this part of the Blue Ridge has not yet been studied in detail, but the region immediately west has been mapped by Keith, ${ }^{,}$and the mine appears to be in a direct extension of a series of schists and gneisses called by him the Carolina gneiss. In general, the rocks of the region are thinly foliated gray gneisses; often schistose when weathered. The foliation has a prevailing northeast-southwest direction and eastward dip. In 1905 the outcrop of the ore body could be seen in only a few old shafts, the gossan, formerly so prominent, being covered by great dump heaps and by the small angular fragments of a hard gneiss which everywhere covers the slopes. The vein has been traced by means of shafts and outcrops for a distance of about $1 \frac{1}{2}$ miles, showing on the summit slopes of the Blue Ridge to the south of the mine and being lost in a ravine between the Ore Knob property and Trainor. The vein appears to have a course of N. $65^{\circ}$ E. magnetic and a dip if $85^{\circ} \mathrm{NW}$.,

a Cranberry folio (No. 90), Geol. Atlas U. S., U. S. Geol. Survey, 1903. 
which accords with the observations of previous writers. The inclosing rocks are hard micaceous gneiss and mica schists, the schistosity having a direction of $\mathrm{N} .57^{\circ} \mathrm{E}$. and a dip of $40^{\circ}$ to $45^{\circ} \mathrm{SE}$. Thus the vein has a course nearly parallel to the direction of schistosity, but being nearly vertical, cuts across the banding of the schists in depth.

According to E. Emmons, the ore body lies in a well-defined fissure in a band of hornblende schist one-fourth mile wide that is apparently intrusive in talco-micaceous schists. This could not be verified by examination of the surface exposures. The material on the waste heaps in mostly a closely puckered, foliated gray gneiss, with quart: nodules and streaks, the foliation showing by the alternation of dark and light layers. Some segregations and lenses of biotite occur.

The ore body consists of pyrrhotite, with a little pyrite and chalcopyrite. It is mainly massive, and in places contains much quart\%. According to Eggleston, one wall is sharply defined, and shows slickensided surfaces, whereas the other shows a gradual transition from ore into impregnated country rock, and this into the normal gneiss. The material shows evidence of movement, and good slickensides and gliding planes can be seen on the larger blocks. Secondary deposits of quartz and chalcopyrite are recognized in the material exposed, and it is said that a quartz streak occurred along the west wall.

Development.-According to Wendt ${ }^{a}$ the development of this property was begun in 1860, languished during the war, and was taken up in 1873 by a strong corporation and vigorously worked. Extensive development of the ore body was made and eleven shafts put down, proving the deposit to have a length of 2,800 feet, and an average thickness of workable ore of about 10 feet, the variation being from 8 to 16 feet. The deepest shaft was said to be 400 feet, and the ore in the bottom to carry as good values as that above. A visit was made to the mine in 1904 and notes on the general geology were obtained; the trip, however, was disappointing, as most of the old workings were found to be inaccessible, and the following notes are taken from the reports of previous observers.

Early descriptions.-The following extracts from the report of Dr. Eggleston, ${ }^{b}$ under date of September 18, 1880, and from that of Wendt ${ }^{c}$ in January, 1886, give information from a reliable source as to the characteristics of the property at that time: The vein is a vertical fissure vein in gneissoid rocks cutting across the strata and

\footnotetext{
" Tendt, A. F., School of Mines Quart., vol. 7, 1886. pp. 224-225.

"Eggleston, Thomas, Investigations of the Ore Knob process : Trans, Am. Inșt. Am. Eng., vol. 10, 1882, p. 25.

- Wendt, A. F., op. cit., pp. 324-330.
} $81777^{\circ}-$ Bull. $455-11 \longrightarrow 9$ 
having a strike of N. $60^{\circ} \mathrm{E}$. The hanging wall is sharply defined. The footwall shows a transition from ore into rock, there being no seam or sharp separation between the two. The vein varies from 10 to 20 feet in thickness. The outcrop is covered with gossan 40 or 50 feet thick, but outcrops for only a few hundred yards near the main workings. Elsewhere it is covered by a few feet of earth, and is exposed only by trenching, by which it has been traced for nearly a mile. The unaltered sulphides consist of pyrrhotite, with chalcopyrite, calcite, biotite, and occasionally a little quartz also occurs. Both the vein walls are vertical, or nearly so, and sufficiently strong to stand without timbering. In 1880 two shafts had been sunk 300 feet and two others 250 feet each. Five other shafts to the north had been sunk to different depths, 60 feet being the shallowest.

Shaft No. 4 south lies 550 feet and the Miller shaft about 1,000 feet south of No. 2. The "Engine" shaft was the one from which most of the ore was hoisted. Stoping was carried on 280 feet distant from the shaft in 1880. At this point the stope is 30 feet deep and the vein 18 feet wide. The next stope is 127 feet long and the vein 20 feet wide. The next is 47 feet long, 30 feet high, and the vein 18 feet wide. A quartz roll appears on the south wall, south of shaft No. 2 south, but the vein makes an increased width to the north side that nearly compensates for this roll. This quartz band continues through the mine for several hundred feet, appearing on the north side, near the engine shaft, but crossing the vein and making a clean and complete separation from the ore-an advantage in mining. The north end of the mine contains only low-grade ore.

The ore was hoisted in iron buckets carrying from 1,600 to 2,000 pounds, but the shaft being single but one bucket could be used at a time.

The cost of mining in 1882 was 65 to 66 cents per ton, and the total net cost of the copper, inclusive of every item, was $12 \frac{1}{2}$ cents per pound, or, making allowances for profits from the company'store, was 10.39 cents per pound.

The Ore Knob copper was exceedingly pure, no other copper in the market approaching it except that from the Lake region. Elaborate tests were made by Professor Eggleston to prove this fact.

The average ore carried from 20 to 30 per cent silica, and was treated without the addition of fluxes.

The ingot copper produced by the Ore Knob works was entirely free from antimony and arsenic, and carried 14.6 ounces of silver per ton. 
As many inquiries have been made for information concerning this deposit and the character of the ore, the following analyses are quoted from Eggleston's paper:

Analyses of ore from, Ore Knoż mine, North Carolina. ${ }^{a}$

\begin{tabular}{|c|c|c|c|}
\hline & 1. & 2. & 3. \\
\hline 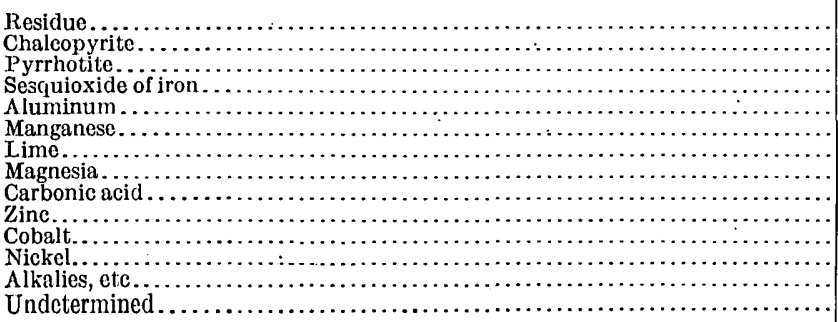 & \begin{tabular}{r|}
29.10 \\
11.33 \\
37.46 \\
8.14 \\
1.84 \\
.16 \\
5.32 \\
.35 \\
4.76 \\
.67 \\
.09 \\
.71 \\
$\ldots \ldots$ \\
$\ldots \ldots$
\end{tabular} & $\begin{array}{r}13.57 \\
13.50 \\
35.74 \\
16.34 \\
1.49 \\
.50 \\
7.84 \\
.94 \\
7.19 \\
.66 \\
.09 \\
.92 \\
\ldots \ldots . . . \\
\ldots \ldots . .\end{array}$ & $\begin{array}{r}12.80 \\
4.76 \\
48.78 \\
18.36 \\
\ldots . . . \\
.70 \\
7.21 \\
.30 \\
6.00 \\
.65 \\
.095 \\
1.08 \\
\ldots \ldots . . \\
\ldots \ldots\end{array}$ \\
\hline Metallic copper in ore.. & $\begin{array}{r}99.93 \\
3.92\end{array}$ & $\begin{array}{r}98.58 \\
4.60\end{array}$ & $\begin{array}{r}100.79 \\
1.65\end{array}$ \\
\hline
\end{tabular}

a Eggleston, Thomas, op. cit., p. 28.

1. Sample from thirteen buckets of ore, each of 1,800 pounds, taken from the high stopes of shaft No. 2 . 2. Sample from sixteen buckets of ore of 1,600 pounds each, taken from the Engine shaft.

3. Sample made by taking a wheelbarrow load from each pile of the pure ore on the surface, the material being quartered down for assay.

The ore of the deposit differs from that of Ducktown chiefly in being more siliceous, this being particularly marked in the ore heaps and extensive piles of siliceous ore rejected while the property was being worked.

The siliceous nature of the ore led to an attempt to treat it by. leaching, and a complete Hunt \& Douglas leaching plant was erected. Owing, however, to the appreciable amount of lime present in the ore, this process was unsuccessful and was abandoned for smelting. The Rio Tinto treatment used some years ago, in which the copper fines were slowly oxidized in the air with the addition of salt, and cement copper produced from the solutions thus obtained, was introduced at Ore Knob about 1884. About 10,000 tons of second-class ore, averaging about $2 \frac{1}{2}$ per cent copper, were treated in this way. It is said, however, that a loss occurred by reason of seepage through the bottom of the leaching yard, and this has been verified by an examination of the property.

Under earlier conditions about 50 per cent of ore mined was sent to the smeltery. The latter consisted of six roast sheds, each 34 by 240 to 400 feet, ten shaft furnaces, one reverberatory furnace, and six charcoal storage houses. Analyses of smelted ores follow. 
Analyses of smelted ores from ore Knol mine, North Carolina.

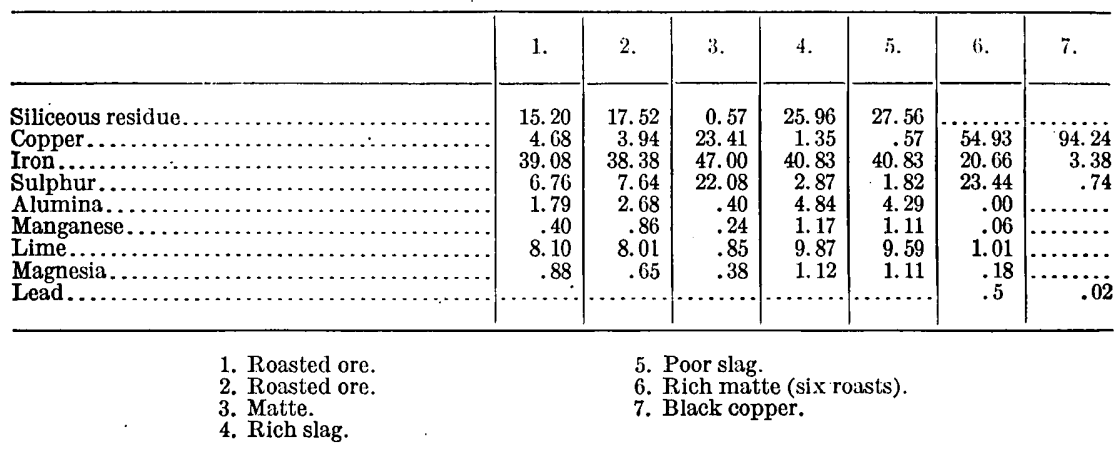

COPPER KNOB OR GAP CREEK MINE.

The Gap Creek or Copper Knob copper mines are situated in the valley of Gap Creek a few miles west of the crest of the Blue Ridge. The ore occurs in well-defined quartz veins intercalated in and cutting across a dark basic schist that is believed to be a metamorphosed basic eruptive. The ore consists of chalcopyrite and of bornite, the chalcopyrite being in large part altered and near the surface showing malachite and other decomposition products of the sulphide ores. The width of the vein varies from 6 inches to 2 feet, and the ore occurs in the quartz in irregular bunches and masses, apparently lying between the terminations of the interlocked crystals which make up the massive quartz. The quartz itself is milky white and very massive. The old workings consist of an adit driven in from the level of the creek for several hundred feet, of a shaft said to be 180 feet deep, and of a second upper tunnel between the shaft and the lower level. All these workings are now caved and inaccessible, but the caving of the shaft has exposed the vein and the schists, so that a good outcrop is seen. The property is equipped with a 10stamp mill, with plates and concentrating tables, engine house and engine, boilers, etc. The property has not been worked for many years.

One of the workmen formerly employed in the mine informs me that free gold is found in the quartz, and it is commonly understood that the concentrates carried between $\$ 50$ and $\$ 60$ in gold. The deposit belongs to the Virgilina type. No examination has been made of thin sections of the basic eruptive, which apparently is a mass of the same general character as that mapped by Keith throughout this Appalachian region under the name of Roan gneiss, At any rate its association with basic eruptives is very intimate, 
The copper occurs in a well-defined quartz vein cutting dark hornblende schists running N. $60^{\circ}$ E. and dipping $40^{\circ}$ SE. There are three quartz veins, only one of which is mineralized. Its strike is $\mathrm{N} .35^{\circ} \mathrm{W}$. and dip $45^{\circ} \mathrm{NE}$. As the workings are inaccessible the following notes are taken from a report by Hanna. ${ }^{a}$ The upper part of the vein had a selvage of iron oxide carrying very high values in gold. The vein on the 60 -foọt level varies from 14 inches to 3 feet in width and has a mineral streak 4 to 6 inches wide in the center. On the northwest drift of this level the vein changes at 53 feet from the shaft and is oxidized, carrying iron oxide and native gold for 36 feet, the course changing to $43^{\circ} \mathrm{W}$.

The ore occurs in films and a netting of streaks and bunches scattered through the massively coarsely crystalline quartz. It consists entirely of bornite, except where weathering has altered this mineral to malachite and other oxidized minerals.

The only record of production is that for 1880 , when it was 40,000 pounds.

\section{PEACH-BOTTOM MINES.}

The Peach-Bottom copper mines lie on the west slope of the Allegheny Mountains, in Ashe County, about 7 miles from New River. The rocks are part of the great series of crystalline schists classed by Keith as Carolina gneiss. The vein is a well-defined layer of schist 4 to $4 \frac{1}{2}$ feet wide, lying apparently conformably with the surrounding rocks, whose foliation is $\mathrm{N}$. $75^{\circ} \mathrm{E}$., dip $60^{\circ} \mathrm{S}$., and containing thin lenticules of dark-red quartz impregnated with chalcopyrite and bornite. The general character of this quartz is very much like that of the Union copper mine at Gold Hill, N. C.; in other words, it is a schist vein. The property has not been worked for many years, and the tunnel is now caved near its entrance, so that access to the old workings is impossible. The general relations of the vein to the surrounding rocks is, however, revealed in a road cutting above the old mine and in the exposures at the mouth of the adit. The property was evidently. worked many years ago, but the old buildings are still standing. There was a 10 -stamp mill of very light stamps, which was used for a short time to crush the ore, but the small amount of tailings present indicates that the attempt was soon abandoned. A small furnace built of soapstone anid about $2 \frac{1}{2}$ feet in diameter was evidently blown in, but was not run long, as the slag dumps is extremely small. An old horse whim with vertical drum still stands above the mouth of the old shaft, which is on the hill about 75 or 100 feet above the mouth of the tunnel. It is said to be 140 feet deep. The ore dumps seen near the old mill are scarcely

${ }^{a}$ Kerr, W. C., and Hanna, G. B., Ores of North Carolina, 1887, p. 225. 
rich enough to pay for working, even under present conditions. The ore is extremely siliceous and the particles of pyrite are small, irregular, and closely interlocked with the quartz, so that extremely fine crushing would be necessary to liberate the values. The ore carries zinc blende and a few specks of galena. Considerable impregnation, though mostly with secondary minerals, appears in the schists adjacent to the walls, and is believed to be the result of the decomposition of the chalcopyrite of the original vein and the seepages of the resulting copper-bearing solutions into the wall rock. The vein itself presents evidence, in its brecciated condition and its inclusion of fragments of country rock, of being a plane of movement whose formation was subsequent to the metamorphism of the schists, and the crushed condition of some of the quartz indicates a postmineral movement.

The deposit is not associated with any extensive area of amphibolite or other basic schists. The immediate wall rock is in part a dark biotite gneiss, and the vein consists in part at least of a shearred quartz gneiss, with much sericite, the chalcopyrite occurring as thin, leaf-like masses interfoliated with the schist. The vein runs N. $54^{\circ}$ E., and dips $80^{\circ} \mathrm{S}$. Its northeastern extension passes beneath the valley bottom and is covered by wash and débris. Southward the vein is lost beneath the soil covering the flat summit of the ridge but is said to be traceable in the drainageways on the other side.

The property can not be considered a valuable one under existing conditions, as the difficulty experienced at the Union Company's copper mine will be met with here, the minute particles of ore being so closely locked in the siliceous gangue as to preclude their separation and concentration and the siliceous nature of the ore preventing its being smelted in the crude state.

A lead vein 6 to 9 inches thick lies alongside of the copper vein and separated from it by a slight thickness of schist.

\section{ELTK KNOB.}

The Elk Knob copper property is located in Ashe County, in the extreme western part of North Carolina, about 2 miles from the township line. The deposits occur on the flanks of Elk Knob (5,555 feet), one of the highest summits of a roughly mountainous tract that forms the divide between the north and south forks of New River. The nearest railroad station is at Mountain City, which lies about 1.7 miles to the northeast and is accessible over roads cut up by the heavy traffic in lumber from the numerous sawmills that are rapidly using up the primitive forests of the region.

The copper deposits occur in the center of an extensive area of gneissoid rocks, mainly hornblende gneiss and diorite, which have 
been grouped as the Roan gneiss by Keith, who has described the general geology of the region. ${ }^{a}$ According to him, the Roan gneiss cuts an older complex of granitic rocks called the Carolina gneiss, but the contacts between the two are so much metamorphosed that definite proof of their relations can not be obtained. Mr. Keith says :

The Roan gneiss consists of a great series of beds of hornblende gneiss, hornblende schist, and diorite, with some interbedded mica schist and gneiss. The hornblendic beds are dark greenish or black in color, and the micaceous beds are dark gray. The mica schist and gueiss beds range in thickness from a few inches to 100 feet and are frequent only near the Carolina gneiss, into which they form a transition. * * * The hornblende schists make up most of the formation and are interbedded with hornblende gneisses throughout. The schist beds consist almost entirely of hornblende in crystals from one-tenth to one-half inch long, with a very small amount of biotite, feldspar, and quartz. The gneisses contain layers and seams consisting of quartz and feldspar, interbedded with layers of hornblende schist. In places these are regularly disposed aud give a marked banding to the rock. * * Many of the beds of this formation consist almost entirely of hornblende and are so basic they appear to have been derived from gabbro. So thorough is the alteration, however, that such an origin is not certain. * * * Thus the Roan. gneiss has passed throtigh two deformations, one producing the foliation and a second folding the foliation planes. During or before the second deformation the bands of quartz and feldspar appear to have been formed.

At Elk Knob the rocks generally appear to be somewhat less hornblendic than is indicated by the above description, but the ore deposit occurs in a mass of basic rock corresponding very closely to an altered peridotite and presumably consisting of an altered basic eruptive.

The main opening lies in the bed of a torrent on the north side of the mountain, about 1,500 feet below the summit, and has extensive dump heaps. The opening consists of a short drift run in on the vein, exposing on the west a smooth slickenside wall, that dips $80^{\circ} \mathrm{W}$. near the mouth of the tunnel and $80^{\circ} \mathrm{E}$. farther in. The vein is 6 feet wide, and consists of hard, dense, fine-grained amphibolite, in alternating layers of impregnated rock and purer streaks of pyrite, chalcopyrite, and pyrrhotite. Along the wall it has a narrow band, from one-half to three-quarters of an inch wide, of nearly pure pyrite. The inclosing gneiss is gray and black and is decidedly curly in structure, showing white quartz in cross fractures. The vein is traceable up the mountain side with difficulty owing to the thick growth of underbrush which everywhere covers the surface, but so far as could be made out the direction of strike is to the northwest, nearly at right angles to the prevailing schistosity of the region.

\footnotetext{
a Keith, Arthur, Cranberry folio (No. 90), Geol. Atlas U. S., U. S. Geol. Survey, 1903, pp. $2-3$.
} 
No work has been done on the property for many years, although numerous examinations have been made at different times. Owing to its inaccessibility, small size of ore body, and intimate mixture of ore and rock, it is not likely to prove an important source of copper in the near future.

Another opening on the south side of the mountain at an elevation of 4,000 feet is also in the bed of a stream, a tributary of Meat Camp Creek. The ore is similar in character to that of the deposit just described. The development work is limited to blasting out the vein in the bed of the stream, exposing about 5 feet of concentrating ore. Near the bottom of the valley, at the south base of the mountain, another opening has been made in similar pyritized rock. The shaft here is caved, but the dump heap shows ore entirely similar to that just noted.

On the south side of the road, in a direct line running through the three openings above mentioned, there is another property on which a tunnel said to be 100 or more feet long has been driven, but no good ore was seen on the dump heap, and work has been abandoned. The fact that these four openings line up and that they are in similar rock has been taken as evidence that there is a north and south lead running through the country, but owing to the very heavy rainstorm prevailing during the three days' visit to this locality and the dense underbrush on the upper part of the mountain, it was impossible to verify this inference. From what has been said it will be seen that the property does not offer any temptation to immediate development.

\section{JACKSON AND MACON COUNTIES.}

\section{IMPORTANT PROPERTIES.}

The Tuckaseegee copper region of the Cowee Mountains in Jackson County, N. C., is a district about 10 miles across, lying east and south of the town of Webster, the county seat. It is drained by the headwaters of Tuckaseegee River, and is a mountainous tract whose summits rise to heights of 4,000 to 6,000 feet above the sea. Two or three years before the Civil War this region was energetically prospected as a result of the furor in copper mining caused by the discovery of the rich secondary copper ores of Ducktown, Tenn. Numerous copper properties were at that time discovered and more or less work was carried on, some of the richer properties shipping ore to the seacoast. With the outbreak of the Civil War all work was abandoned and only in recent years was an attempt made to reopen any of the property. The following list comprises the more important properties:

New Savannah, or Betts Gap mine, belonging to Mr. W. S. Adams.

Brendle Knob mine, belonging to the Carolina Copper Company. 
Way-Ye-Hutta mine, belonging to the Carolina Copner Company.

Cullowbee mine, belonging to the Cullowhee Copper Company.

Tuckaseegee mine, belonging to Alfred M. Low.

Old Savannah Mining Company (The Ehlor Mining Company), now owned by W. S. Adams.

Sarannah Copper mine, belonging to Cox, Davies \& Co.

Buck Knob mine, belonging to Mr. Davies.

Highland Forestry Company property, otherwise known as the National Abrasive Company, owning a tract on Sngar Top Mountain and Deviltop Mountain.

Poor Ridge mine, belonging to Davies \& Co.

Davies mine, belonging to Judge Davies.

Wolf Creek Copper mine, belonging to the Buchanan Company.

The rocks of the region are gneisses and schists of pre-Cambrian age, containing "soft hornblendic slates" or amphibolites with associated copper deposits. The rock is soft and friable. The foliation runs $\mathrm{N}$. $34^{\circ}, 50^{\circ} \mathrm{E}$., and commonly dips steeply to the northwest. The veins are conformable, or nearly so, to the schistosity, and are everywhere associated with or formed by an impregnation of the soft hornblendic slates which constitute the copper bearer. These "veins" are from 10 to 15 feet thick and are capped by gossan, by which the veins may be traced for many miles.

The ores consist of chalcopyrite, glance, and gray copper with the common decomposition products near the surface, especially at the Way-Ye-Hutta mine and Savannah. With a few exceptions, the mines have not been worked for many years, and the nature of the ores can only be judged from the material on the old dumps and the structural relations of the outcrops. They occur in or alongside of hornblende gneisses that in places consist of pure hornblendes, but generally of quartz and hornblende, and represent altered gabbro and diorite. Pyrite lenses are common along these belts of basic gneisses. In general the ores occur in the hornblende rocks, but are found also in the gray gneiss alongside. Where faulting is distinguishable, it is noted that the fault plane, usually an overthrust, has itself been folded and presents all the peculiarities of a folded bed.

There are two principal parallel veins, the Cullowhee to the east, and the Way-Ye-Hutta to the west, the latter being also known in parts of its course as the Shell Ridge and the Savannah lodes, though some observers.maintain that the two last named are independent but parallel veins. The Way-Ye-Hutta has outcrops of gossan and tremolite and at various openings shows carbonate and copper pyrite. The Cullowhee vein has on it the Cambuco, Wolf County, Cherry Gap, and Loudermilk mines. The workings of the first named showed in 1863 a width of 6 feet, with well-defined walls, one of gneiss and the other of talcose slates. 
CULLOWHEE MINE.

Ore bodies.-The ore bodies occur along the contact between the amphibolite and the gray Carolina gneiss. The former, the footwall rock, is of undetermined thickness. The shaft and the crosscut tunnel afford good exposures for 100 feet or more from the vein. These workings show a fine-grained, dark, micaceous, hornblende gneiss, showing intricate plications, passing into a coarsely granular hornblendite or amphibolite near the ore body. This rock is cut by a dike of gray acidic gneissoid granite, 2 to 6 feet wide, with somewhat irregular boundary, cutting across at $60^{\circ}$ to $90^{\circ}$ to the foliation of the gneiss, but apparently not faulting it. This rock is cut in the 50-foot crosscut in the shaft, and is seen one-half mile from the mine, where the wagon road crosses the mountain slope.

To the west of the shaft the main ore body terminates abruptly at a point about 50 feet from the shaft. At this point there is a fault slip, and beyond it the gneissoid rock carried pegmatite, but the exact relations of the latter were not determined owing to the difficulty of recognizing the rocks in the wet and soot-covered walls. The drift is said to follow a thin layer of ore which is supposed to be the apex of an ore body, the ore being found in the floor of the drift and extending upward for 2 or 3 feet above it, but the roof of the drift shows no ore whatever. At 170 feet west of the shaft the crosscut carried some small bunches of ore in crushed rock and at 174 feet a breast of ore $2 \frac{1}{2}$ feet wide was encountered.

To the east of the shaft the main ore shoot extended almost to the face of the drift, 150 feet from the shaft, where a cross slip throws the ore into the hanging wall.

The dump heap and also the west drift of 100 -foot level shows a very coarse-grained pegmatite, carrying much biotite in places with tourmaline and hornblende; but no transition to amphibolite was observed. That the rock carries chalcopyrite shows age of the latter to be the same as that of the pegmatite formation. The occurrence of corundum as a normal (but rare) constituent of this acidic rock is noteworthy. Two ore bodies are known.

The deposit is relatively low grade, the material in the ore bins appearing to average about 5 to 7 per cent copper. The deposit has an average width of 3 feet and a maximum width of 6 feet, and the length of the developed shoot is about 200 feet horizontally. Little evidence of movement appears along the course of the ore body. The old adit level, later known as the 50-foot level, was driven in 1860. It reached the ore body at the water level and disclosed a little sulphide ore, but the oxidized ore was the most abundant and was selected and shipped. Although fresh faces are now exposed by the cleaning out of the old workings, no deposits of importance are found 
showing earthy or sooty glance. Most of the rather extensive work driven on this level for prospecting purposes was without system and was unproductive of results.

The ore.-The ore consists of chalcopyrite in bunches and films and as disseminations through massive pyrrhotite. It varies considerably in the relative abundance of these sulphides and locally lacks pyrrhotite. In places it contains irregularly rounded, blebby masses of quartz up to one-half inch diameter. The footwall is usually well defined and has a dip of $48^{\circ}(?)$, but in places the mineralization fides into the wall rock. The hanging wall is irregular. The vein is not well-defined; the contact is curving and ore bodies are lacking in places. It has steep cross slips, fault matter, and soft crushed rock carrying new endogenous ore. Its course is $\mathrm{N} .48^{\circ} \mathrm{E}$.

The contact vein has a dip of $48^{\circ}$, and the shaft sunk in the hanging wall cuts through the ore body 87 feet below the surface. At this point the ore consisted of a very open textured mass of coarsely crystalline pyrite, imperfectly cemented by black and earthy glance. The only other copper mineral seen was in an upraise carried from the 100-foot level for 47 feet on the dip of the vein. In this upraise considerable amounts of covellite were found. The pyrrhotite and pyrite always predominate, but the amount of each mineral varies widely from place to place.

The ore is compact, vugs being rare. There is no real gangue, but the mixture of minerals forming the ore includes rounded, apparently etched grains of quartz (with secondary enlargement?) and grains of feldspar, spinel, pyroxene, and other constituents of the wall gneiss. Locally these minerals show enlargement; the core being like that of the same mineral in the gneiss and the shell consisting of accreiions containing inclusions of pyrrhotite. Secondary calcite, etc., occurs as crusts, veinlets, and sessile crystals. The ore body holds occasional fragments of country; surrounded by crusts; and patches of wall rock are impregnated with ore and show a microbreccia structure, with sulphides of iron and copper in the microscopic fractures. All this evidence shows that the ores are not of sedimentary but of secondary origin, and are formed by solutions that penetrate into a zone of crackled and crushed rock. The mineralizing waters caused partial metasomatic replacement of rock by ore minerals, with enlargement and regeneration of a part of the corroded original constituents. The waters are supposed to be the result of a granitic intrusion.

The ore occurs as lenses in an amphibolic rock that itself contains disseminated particles of pyrrhotite, chalcopyrite, and pyrite. In this rock the sulphides appear in thin section to have been the last minerals to crystallize out, as many corroded fragments of pyroxene and hornblende are surrounded by pyrite, which also occurs between 
the plates of biotite. Portions of the ore are rich in corundum. These relations and the fact that the pyrite is in the altered silicates indicate that the ore was formed at the time the hornblende was uralitized, as a deposit from hot waters, and is therefore to be regarded as an after effect of the intrusion itself. The corundum has made diamond drilling too expensive a mode of prospecting for use at this property.

Development.-The development work of the mine consists of a vertical shaft 160 feet deep, well timbered and lined for buckets, and a ladder-way. Levels are driven at 50 feet and 100 feet and a crosscut at 160 feet. The latter extends for 140 feet from the shaft, but does not cut the vein, although an upraise driven 10 feet above the roof of the crosscut failed to disclose ore. The flow of water is rather heavy, requiring six hours' pumping per day to lift it to the 50 -foot level, whence it drains out. The property is equipped with steam boilers, engines, air compressors, and a 2-drum steam hoist.

\section{LTTTIE TEN NESSEE MINE.}

The Little Tennessee property first attracted attention in 1857. It is located 4 miles from the Georgia line and about 10 miles south of Franklin, Macon County. The vein has a gossan cap and carries black copper ore 30 feet below the surface. The width is unknown.

\section{NAN'TAHALA MINE.}

The Nantahala mine is on one of the spurs of Nantahala Mountain, on a branch of Cartoogechaye Creek about 4 miles southwest of Franklin. The vein is in the Catoctin schist near a bank of hornblendic gneiss, and consists of chalcopyrite and gray copper with granular quartz gangue. The strike is N. $40^{\circ}$ E., agreeing closely with the foliation of the rock, the vein occasionally cutting at $10^{\circ}$ to $15^{\circ}$ across the schist. The vein, according to old reports, is 35 feet wide and is marked by an outcrop of hornblendic rock with sphalerite, quartz, and limonite. According to Kett, the vein at Way-ye-Hutta mine is 5 to 6 feet wide, and at Savannah is in several beds, the widest of which measures from 9 to 10 feet.

\section{DAVIDSON AND ROWAN COUNTIES.}

\section{COPPER-GOLD DEPOSITS. ${ }^{a}$}

Gold Hill district.-A large number of copper-bearing ore deposits of the South are gold veins, which have been and still are worked for their gold contents. In many of the gold veins, of North Carolina

\footnotetext{
a Weed, W. H., Types of copper deposits in the southern United States: Trans. Am. Inst. Min. Eng., vol. 30, 1901, pp. 470-471.
} 
especially, the mines were opened, the oxide ores extracted, and sulphides encountered at the water line. At some places these sulphides have been successfully worked as gold ores. More often the mine was abandoned when the sulphides were encountered, especially if the ore contained an admixture of copper pyrites which prevented successful amalgamation. In many of the mines the sulphide ores were found to contain from 2 to 5 per cent of copper, present as chalcopyrite. A few properties of this kind are now successfully worked for copper, their auriferous contents being in most cases sufficient to give them an additional value. The Gold Hill mines are of this nature, and as they are now being extensively opened and exploited, they have been taken as a type of the auriferous chalcopyrite veins of the South.

\section{GOLD HILL MINES. ${ }^{a}$}

Location.-Gold Hill is 14 miles southeast of Salisbury, on the Piedmiont Plateau. The country shows a relief of 200 to 300 feet, broad stream levels separating flat-topped ridges, steeply trenched by lateral drainages. The Gold Hill district was formerly densly wooded, but has now been largely denuded about the mines and in the vicinity of the few farms which dot the region. The veins occur on a narrow plateau ridge running northeast and southwest and which is about $1 \frac{1}{2}$ miles long and two-thirds of a mile wide, the region being bounded by Buffalo Creek on the west. The veins are in an area of metamorphic schist, mostly argillaceous, bounded by an intrusive mass of granite on the west and by metamorphosed dioritic rocks on the east. The schists show a foliation of N. $30^{\circ} \mathrm{E}$., and dip $75^{\circ}$ to $80^{\circ}$ W. The veins have been proved to a depth of 800 feet and have been traced on the surface for more than three-fourths of a mile. But their outcrops are obscure and the continuity of the veins has not as yet been established beyond doubt. The ore occurs primarily in quartz; but small amounts are found disseminated through the altered schists.

History.-In the reports of the North Carolina géological survey upon the gold mines of the State those of Gold Hill are fully described. It is said that these mines were discovered in 1842, which was a comparatively late date in the history of gold mining in the State. They were worked until 1856, yielding in 14 years over $\$ 2,000,000$ in gold. The sulphides were then encountered, and from that time until 1874 about a million dollars were extracted, but as the process of simple amalgamation extracted only 20 to 30 per cent of the value the ores were regarded as unfavorable. Gold mining was practically stopped in 1893, and from that time until 1899 no 
mining was done. The treatment up to 1881 was with Chilian mills and rockers. At that time a 20-stamp mill was put in. An attempt. at cyanide extraction was made in 1893 , but without success. At the Isenhour mine, near by, the ore is pulverized in a Howland crusher and concentrated on blankets and the concentrates are washed in log rockers with quicksilver.

The gold product of this district came from several veins, but the main producers were the Randolph and Barnard mines. The shaft

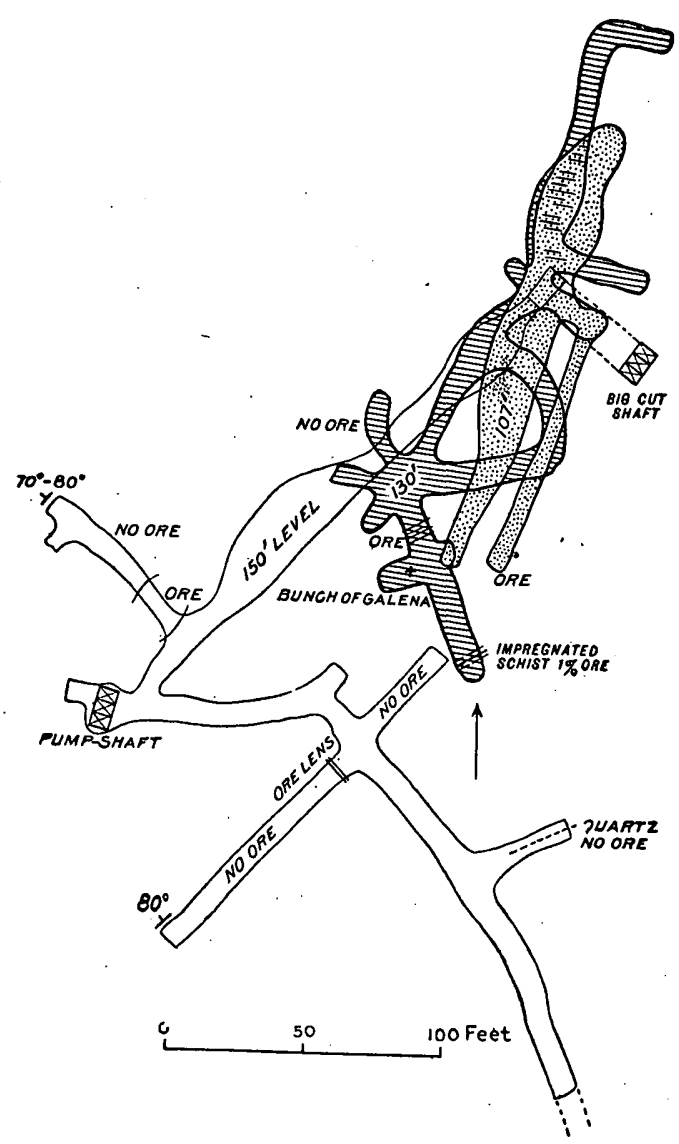

Figura 30.-Workings of Union Copper Company mine, Gold Hill, N. C. at the Randòlph mine is 800 feet deep, and has been practically worked out down to the 500-foot level. As developed in mining operations, the values occurred in shoots, and one of these proved too rich in copper to pay for working by amalgamation as a gold ore; so that this body has never been stoped. The mine is now being unwatered, and if the reports of the value of this copper shoot be true it may become a producer of auriferous copper ores. During the active exploration of the district a number of shafts 100 to 200 feet deep, and a great many shallower pits were made for the extraction of the oxidized free gold ores. The Union Copper Com-

pany's tract was explored in this way, and a deep open cut was made on a zone of mineralized and oxidized schist (locally slate) which carried gold. At 25 to 30 feet copper was encountered; and the vein received the name of the $\mathrm{Big}$ Cut copper vein, by which name it has been mentioned in numerous official reports.

The rocks.-The rocks of the region are greatly decomposed, and except where exposed in the banks of ravines have weathered to reddish white or rusty slaty débris. The fresh material from the 
mine workings is, however, gray or blue in color, and varies from a very dense and hard, siliceous gneiss to soft talcose material. Under the microscope the rock shows a mixture of quartz and biotite with some hornblende. The quartz is very finely granular, but holds veinlets and spots of coarser grain. There is much pyrite usually associated with the green hornblende.

Vein phenomena.-A mineralized belt extends along the edge of the hill, from the mines seen in the village of Gold Hill, beyond the Union Copper Company's workings, in a direction generally parallel to the schistosity of the rock. There are lesser veins, recognizable in part by outcrops and in part by old prospect pits, which run across the banding of the schist and end in the belt mentioned. As a rule, the so-called gold veins are recognizable only by the greater amount of iron staining the weathered rocks; and the few visible outcrops of quarts are barren of value and do not form well-marked veins. That the veins of the district are true fissure veins and continue in length and dip, is clearly proved, however, by the workings of the Barnard and Randolph mines nearby.

The exact nature of the copper deposits and their relation to the schists have not been conclusively determined. So far as the writer was able to observe, the ore shoots conform in dip and strike to the secondary schists, and pitch to the north. They show no banding. Composed largely of a distinctly and finely graular dark-gray quartz, with patches, spots, and streaks of ore, they present little or no crystalline or massive white or transparent quartz such as is commonly seen in quartz veins, and is usual in the auriferous "stringer lodes" of the South. A large part of the ore shoot consists of a breccia of fragments of hard, white, silicified schist, inclosed in quartz ore, showing conclusively that the slates were shattered and breccia zones were formed before the ore-bearing solutions became active.

The ore bodies show no well-defined walls, clay slips, or seams, They have, however, been fractured by later movements, as is shown by vertical fractures, which serve as conduits for descending waters, and by subordinate flat fractures connected with the first and believed to be a result of the strains resulting from the formation of the first fissures. These flat fissures dip south at $20^{\circ}$ from the horizontal.

The only ore shoot exposed at the time the property was visited (December, 1899) showed a length of about 150 feet and a width of 20 feet and extended from the upper level to the deepest [800-foot] workings.

Character of the ore.-The ore below water level consists of pyrite, chalcopyrite, and quartz, with occasional bunches of galena and 
blende. The pyrite is in broken, shattered masses, in part cemented by chalcopyrite, which is distinctly later in origin, and surrounded by quartz of coarser grain than the main mass of the ore. The extreme upper part of the vein is leached and barren of copper, but has been worked for its gold. Below this rusty weathered zone the vein shows marked alteration; the quartz and schist are dull, shattered, and rust-stained, and carry blue and green carbonates, cuprite, and native copper-the oxide often in beautiful crystals. Below this the ore body shows opaque white quartz of a sugary or flour-like texture, carrying sooty black sulphide of copper, and passing into the oxidized ore where pipes and water channels extend down into it. This partially altered ore contains crystallized and massively crystalline and dull chalcocite, and nucleal masses of copper pyrites may be seen, surrounded by all the alteration products mentioned. The alteration takes place especially along the vertical fractures, and those dipping at $20^{\circ}$ which connect with the verticals. In general the vertical fissures are marked by oxidized material, leached of copper, even down to the 150-foot level, which fact leads to their designation as gold veins. The flat-dipping fractures usually show red oxide and sheets of native copper. While there is no sharply defined limit to the zone of enrichment, the ore shoot is markedly enriched for from 15 to 20 feet above the sulphide ore.

Origin of the ore.-The ores show no banding or crustification, but do exhibit a brecciated structure. The quartz is not massive, and the ore-bearing quartz has not the characters of quartz filling an open cavity. On the contrary, a study of the occurrence of the ore in the mine and of specimens indicates a replacement of schist by quartz, or a replacement of the ferromagnesian mineral by ore. The study of thin sections shows that a mass of silicified schist, holding pyrite, has been shattered by fault movement, and chalcopyrite, together with a little galena and blende, and a new growth of quartz has been deposited. The chalcopyrite has been altered in part to bornite, and to glance near the water level, or to cuprite and malachite and azurite when oxidation has been more pronounced.

The Gold Hill mines were not worked in the summer of 1904, though the shaft of the Union Copper Company was being pumped out. The company shipped ore from the dump heap to the Ducktown smelter:

\section{MISCELLANEOUS COPPER-GOLD MINES.}

The Conrad Hill mine is situated about 6 miles west of Lexington. The property has not been visited, but according to reports of reputable engineers it shows two systems of veins, in which the ore consists of chalcopyrite and pyrite, with free gold in a gangue of quartz and siderite. The ore shoot shows a maximum width of 18 feet, and the 
vein has been developed to a depth of 400 feet. Other mines in this. vicinity are said to carry similar ore.

The Lalor mine, 2 miles from Thomasville, shows chalcopyrite and pyrite in a vein developed by three shafts, the deepest being 140 feet vertically.

The Emmons mine is another property carrying chalcopyrite with some gold. It is situated about 15 miles from Lexington. It shows a vein 3 feet to 8 feet thick, which is developed by an inclined shaft 400 feet deep.

The Cid mine is a similar property, lying 1 mile from the Emmons mine.

\section{GEORGIA.}

M.AGRUDER OR SEMINOLE MITNE. ${ }^{a}$

The chief copper mine of Georgia is situated on the border between Wilkes and Lincoln counties, in the northeastern part of the State, 12 miles from Washington, which place is accessible by the Georgia Railroad from Atlanta and Augusta. The mine was visited by the writer in 1904 and was being worked in January, 1906.

The country is part of the broad expanse of the Piedmont plain, averaging about 500 feet above tide and having very flat or gently inclined surfaces. In the vicinity of the mine the stream bottom is 95 feet below the plateau top. Though intersected by a great number of branching streams, this part of the State is relatively dry and the streams are very low in summer, the water supply being derived from springs. Little River is about 12 miles away.

The rocks of the region consist of soft micaceous schists, with numerous dikes of basic igneous rock, all deeply decomposed by atmospheric agencies, so that red-clay and pale-brown soils predominate and relatively few exposures are seen. Indeed, the road cuttings on the route from Washington to the mines show merely a spotted clay, without banding or recognizable bedding, and are assumed to be a residual product of rock decay. The basic dikes are micaceous and are clearly intrusive, since they cut across the foliation irregularly. They can be accurately determined only when fresh material is available, as at the mines. Comimonly it is impossible to secure determinable material. They are mainly diabasic in character.

This part of Georgia contains several groups of producing gold veins, those of Columbia, on Little River, 8 miles southeast of Washington, being best known. The gold occurs in a milky-white quart\% forming lenses of the type designated segregation veins by most authors in the mica schists.

a Other notes on this mine are glven by 'T. L. Watson in Bull. U. S. Geol. Survey No. 225, 1904, pp. 182-186.

$81777^{\circ}-$ Bull. $455-11-10$ 
At the Seminole mine copper ores are found in veins formerly worked for gold, and later when sulphides were encountered the copper and lead ores carrying gold and silver were shipped.

A large body of high-grade pyrite was opened in 1905 in the vicinity of Dahlonega. The occurrence of this mineral in at least one body of workable size has been known for some time, but until 1902 the deposit had not been opened sufficiently to justify any statement as to its value. During 1905, however, exploitation was carried far enough to permit some idea being formed as to the size, uniformity, and grade of the deposit.

Two other pyrite properties are being worked in the northern part of the State.

The Seminole Mining Company acquired the Magruder property in 1900 , and at present writing (1906) has opened up the property, sinking a shaft to a depth of 200 feet on the Wardlow vein, with levels at 125, 145, and 185 feet. The 145-foot level connects, by a crosscut 800 feet long, with a level driven on the Magruder vein. These workings are all below the oxidized zone and expose unaltered sulphide ores. The older workings extended to a depth of about 125 feet on the two largest veins. They are in part accessible and show pillars of relatively high-grade ore.

The veins are well defined in the weathered zone and their schistose structure is most quickly recognized in this condition. There is little ironstone gossan, and the veins are not continuously traceable by outcrop, although in part the tract is virgin ground covered with great oaks that have never been cut, so that cultivation has not obscured the outcrops. Open-cut work and numerous shafts have, however, disclosed the course of the Magruder vein, which was the only one known until a long crosscut tunnel, oblique to the vein, was driven from the foot of the hillside and encountered other nearly parallel veins.

The veins have a general course of N. $43^{\circ}$ E. magnetic, and dip west. Three distinct and well-defined veins are known-the Magruder, Finlay, and Wardlow-but the entire space between the Magruder and Wardlow veins is an altered silicified and pyritized shear zone of schist, in which there are several veins, so far as known, of nonpersistent value.

These veins are cut across and faulted by dikes of diabase and other basic rocks, which are massive and not schistose, and are clearly later than the veins, since they contain angular detached blocks of ore in the dike rock. The general course of these dikes is north and south. Their intrusion was accompanied by movement and shattering of the country rock.

The veins have a generally schistose structure and include a more or less continuous streak of quartz containing sulphides. This quartz 
is not the white, milky quartz of the gold veins nor is it coarsely crystalline: It is usually a dense dark-gray rock, whose metallic particles are scattered through it in a general banding. Slivers of included schist occur.

The ore bodies range from a few inches to 8 or even 10 feet across. In the Wardlow vein the main ore shoot is 35 feet long on the 125foot level and 60 feet long on the 145-foot, averages 3 feet wide, and is continuous in richness and character to the 185 -foot level. It is cut off west by the diabase, and, though some blocks of ore show the break was across the ore shoot, the offset faulted portion has not yet been recovered.

In examining the mine workings several interesting details of structure are observed. The Wardlow vein in vertical section in the ore shoot has a steep, nearly vertical dip, with two flat offsets to the east on the 90 -foot level. (This and the general dip show that the vein does not conform to the foliation of the schists.) The 145-foot level, which is the most extensively developed, shows several trap dikes, which terminate the main ore shoot of the Wardlow vein on the south. The first dike, 20 feet from the crosscut to the shaft, is a foot thick, has a course N. $20^{\circ} \mathrm{E}$., and dips $55^{\circ} \mathrm{W}$.; though it cuts through, it does not cut out the ore; it cuts across the ore body where it has narrowed to 2 inches. At this point it looks as if the fracture continued across the dike. The second dike encountered is 3 feet thick and is nearly parallel $\left(\mathrm{N} .10^{\circ} \mathrm{E} ., 75^{\circ} \mathrm{W}\right.$.) to the first. No ore is found on its south side for 100 feet or so, when a crosscut north cuts an ore body. The level follows an altered soft layer in the schist, rendered tender by slipping.

The ore body shows in north end of 185-foot level a thin clay selvage, and exhibits rounded, slickensided, and grooved faces, showing downward movement.

On the 145-foot level the south ore body of the Wardlow vein shows two to three strealss, aggregating perhaps 3 feet of ore, in well-defined bands, separated by white pyritized schist with walls of the same, there being all told about 15 feet of milling rock, concentrating 6 to 1 .

Cross joints, locally called "heads," cut the ore body and in places limit it, though usually merely effecting a local change in values. These "heads" are shear planes, tending S. $50^{\circ}$ E., vertical, or S. $15^{\circ} \mathrm{W}$., with dips of $30^{\circ} \mathrm{S}$. and $60^{\circ} \mathrm{N}$. These fractures also appear in the large mass of diabase encountered at the south end of the 185-foot level as closely but irregularly spaced shear joints tending N. $35^{\circ} \mathrm{W}$. and dipping $80^{\circ} \mathrm{SW}$. A fine slickensided cross joint runs from the north wall of the crosscut to the shaft on the 185-foot level. 
The diabase, which is recognized even when decomposed by its splintery blocky fracture, has no ore, no quartz, and no pyrite. In the Magruder vein workings on the 145 -foot level it shows a flat $20^{\circ}$ pegmatite seam 2 inches wide.

The Magruder vein is the largest and most persistent vein, as shown by the old workings, but the new level is too badly caved to show the new ore body. A shaft 80 feet deep does not reach the present level, the end of which is about 300 feet south of the shaft and 100 feet below the collar. The vein has been crushed by later movement and is very wet. It carries about 3 per cent copper and $\$ 2$ gold, being relatively low grade, but it is easily mined, the cost being estimated by Henrich at about one-third that required to mine the Wardlow ore, and it is large and will be the mainstay of the mine's future. The north end of the drift is in a black, sheared, shistose basic rock, characterized by abundant cubes of pyrite, the largest having sides one-half inch square.

Between the Wardlow and Magruder veins the rocks are sheared and altered. In part they consist of almost pure-white quartz sericite schist, more or less silicified; in part of schist with quartz bunches and streaks, and in part of pyritized schist.

There are several veins of which one, the Findlay, was worked by the former owners. The present development consists of a south drift from the crosscut 55 feet long, and a 27 -foot drift north to an upraise to the 125-foot level. The ore narrows up westward and the workings are in white schist showing abundant pyrite.

A second vein to the west varies from 2 inches to 3 feet, shows zinc blende and pyrite, and has walls of pyritized white schist, but the ore is bunchy and not persistent, as shown in a raise to an old shaft.

The diabasic intrusions of this property are postmineral, and hence can have had no influence on the primary vein filling. They cut off the ore bodies and fault them, and in one exposure (125-foot level) contain an included torn-off fragment of the vein. On the 185-foot level the trap rock does not sharply truncate the ore where the dike cuts across the schist, but contains a mass of ore projecting in the diabase. There is, however, evidence of postmineral movementboth slipping and crushing - of the ore bodies, which is most reasonably correlated with the period of diabase intrusions and which has been followed with vein water, with migrations of copper and other metals and consequent enrichment. This is particularly marked in the Magruder vein.

The ore bodies proper occur in a zone of sheared, highly altered, sericitized schist, altered from gray quartz-mica schists to lustrous pearly white rock, with abundant auriferous pyrite, especially along the veins. 
The ores differ from the gold quartz ores in their schistose character, in the tough dense nature of their quartz, and in the abundance of zinc blende, galena, chalcopyrite, and pyrite they contain.

An average sample of the pyritic first-class concentrates from the bins, analyzed in the Survey laboratory, showed 9.3 per cent silica, 0.59 per cent baryta, and traces of lime, magnesia, and zinc. A calculation of the mineral composition of the second-class concentrates made by the owner, Mr. Carl Henrich, is as follows:

Mineral composition of ore from Magruder mine.

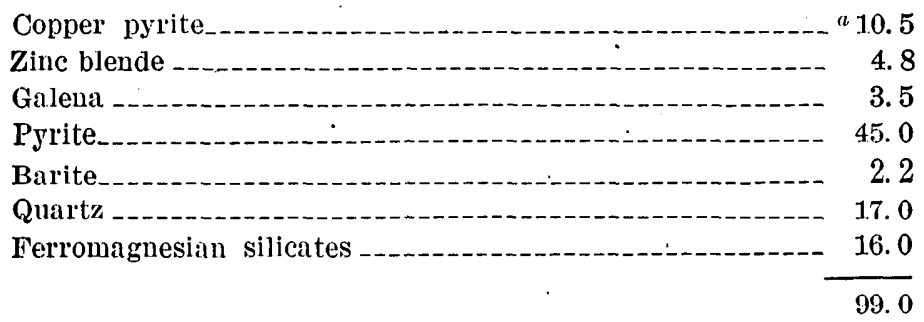

This is not, however, an average sample of the ore body, but is the result of milling a large tonnage of the pyrite-bearing white schist found between the veins. A sample of this schist pulverized and panned for the writer yielded a concentrate of nearly clear pyrite, which was assayed, yielding $\$ 10.80$ gold and 4 ounces silver per ton, and 0.1 per cent copper. The first-class mill concentrates taken from the ore bins carried $\$ 7.60$ in gold per ton, and 7.1 ounces silver per ton. The second-class concentrates have the following approximate composition: Quartz, 2.5 per cent; alumina, 4.5 per cent; iron, 26.2 per cent; lime, 0.8 per cent; magnesia, 0.3 per cent; barium oxide, 1.6 per cent; copper, 3.6 per cent; lead, 3 per cent; zinc, 3.2 per cent.

\section{CHESTATEe PROPERTY.}

The property of the Chestatee Pyrites Company is located about 6 miles from Dahlonega, in a direction a little north of east. The openings are located on the south side of Chestatee River, about 2 miles west of its junction with the Tessantee.

The outcrop of the pyrite body has a direction of N. $45^{\circ}$ E., and dips at an angle of about $45^{\circ} \mathrm{NW}$. On examining the stratigraphy it was found that in position, form, and association this pyrite deposit closely resembles the typical gold deposits of Dahlonega. The pyrite forms a "bedded" vein, which is conformable to the quartoze mica schists that overlie it on the west. The rock adjoining the pyrite on the east, however, is of the same type of hornblende schist as that described above in connection with the Dahlonega gold 
veins: As with those deposits, the pyrite body occurs on the contact between a normal (and possibly sedimentary) mica schist and a hornblende schist, which is a much-metamorphosed igneous rock of early date.

The deposit has been thoroughly opened at two points in addition to the pits and trenches which have been dug in order to test the continuity of the deposit. The northeastern opening is a tunnel, driven completely through the vein. Two drifts diverge from the tunnel at right angles, both being run parallel to the trend of the vein. One of the drifts is run on the western or hanging wall of the vein, the other on the foot wall. About 100 feet southwest of the tunnel opening an incline has been sunk on the dip of the vein, a depth of 60 feet below the mouth level having been attained at the time of visit.

These workings, taken in connection with somewhat extensive diamond-drill explorations and the examination of natural ourcrops, would seem to give a fair basis for calculating the size of the deposits. The outcrop extends at least 2,000 feet along the surface of the ground. Where it has been effectively crosscut by tunnels and incline the pyrite body is about 30 feet in thickness, and trenches and drill borings appear to prove that its thickness at no point along the 2,000 feet of exposure falls below 20 feet. It has been followed down on the dip for a distance of almost 150 feet.

The body of ore seems therefore amply large for profitable exploitation. The operating company has adopted a wise policy in this respect, the intentions being to push underground working and accumulate a large supply of stock ore before commencing to build a treatment plant.

Eight carloads of ore were taken from the tunnel, thus securing a sample entirely across the vein. The average of the analyses is as follows:

Analysis (averago) of Chestatee pyrite.

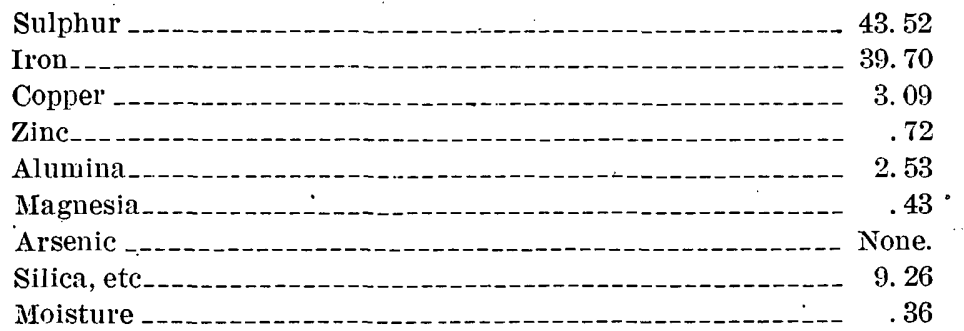

Analyses from the middle 20 feet would show a higher sulphur and lower copper content than the average analysis quoted, while analyses of the portions of the pyrite body near the walls would 
give lower sulphur and higher copper. It is probable that this difference in composition, which can be noticed even in a hand specimen, will be taken advantage of in planning the treatment of the ores.

\section{BAR'YOW PYRITE PROPERTY.}

The Bartow pyrite property is situated on the line running from Atlanta to Chattanooga. The pyrite occurs in a vein 7 feet wide, consisting of pyrite, quartz, and pink garnet. The ore runs about 32 per cent sulphur, but can be concentrated like the ore of Villarica to 45 per cent sulphur. In 1905 the property was owned by $\mathrm{Mr}$. Smith, of the Cherokee Pyrite Company, Atlanta, Ga. According to him the Villarica property shows a loss of about 30 per cent in concentrating the material in Hartz jigs. The property contains three veiris, one of which is gold-bearing.

\section{EMERSON PYRITE PROPER'TY.}

The Emerson pyrite property is situated near the city of Emerson, on the Western \& Atlantic Railway, north of Atlanta. The pyrite occurs in bands in a carbonaceous slate, which is mined as a filler for fertilizer phosphates. The width of the material is about 500 feet, and as the pyrite occurs in bands, which could be separated, the pyrite itself forms a valuable asset. There seems little doubt that a washer would effect a fairly clean separation between the pyrite and the slate. At present writing (1905) the property is worked by an open cut, exposing a face about 90 feet high. The material is put through a gyratory crusher, which reduces it to 16 -mesh dimensions. The output is about 100 tons a day, and the price realized is $\$ 1.25$ per ton. The expense account is as follows: Mining and crushing, 45 cents; salaries and expenses, 20 cents; freight, 60 cents.

The material has the following composition, as determined by N. A. Pratt, chemist, of Atlanta, Ga.:

\section{Composition of rock-at Emerson property.}

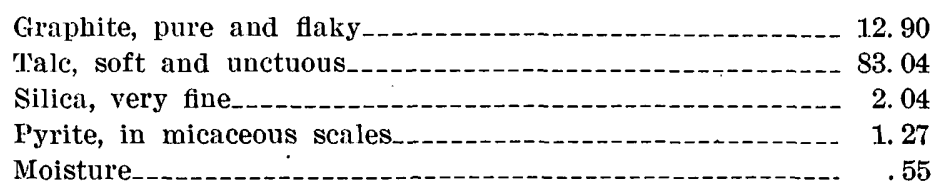

An analysis by Prof. H. C. White, of the University of Georgia, vielded 2.85 moisture, 5.12 carbon, with small amounts of hydrogen and nitrogen. 


\section{TENNESSEE.}

\section{THE DUCKTOWN DISTRICT.}

The Ducktown district is situated in the extreme southeastern corner of Tennessee, in an open basin inclosed by bounding mountains on the east and west, Ocoee River on the south, and a broad plateau level on the north. The ore deposits occur in a belt about 2 miles wide and 4 miles long, their general distribution being indicated upon the accompanying map. The rocks are gneisses and schists, usually weathering readily, so that good outcrops are not frequent, and disintegration commonly extends to a depth of 50 to 90 feet. In the best exposures the prevailing rocks are micaceous and very finely puckered. They are biotite-quartz schists and hence are of sedimentary origin, and are regarded by Keith as the lower part of the Ocoee series of early Cambrian age. The schists have throughout the district an average strike of $\mathrm{N} .20^{\circ}$ to $25^{\circ} \mathrm{E}$., and. dip $50^{\circ}$ to $55^{\circ} \mathrm{E}$. The original bedding planes cut across the schistosity.

The Ducktown, Tenn., deposits were actively worked from 1852 to 1855 for their secondary enrichment ores. The Cherokee and Tennessee mines were opened early in 1855 , and the Hiwassee in the latter part of that year, the other mines being opened in 1854 . Up to July, 1854, the different mines had produced a total of 18,569 tons, of which 17,735 tons were produced in the preceding year. This ore being soft was extracted with picks and shovels, the hard lumps broken, the ore sacked and shipped to Baltimore. As shipped the ore averaged 32 per cent copper, and had a gross value of $\$ 192$ per ton.

The Tennessee Copper Company's great plant has made this one of the great copper-producing districts of the world. The ore bodies have been systematically and extensively opened up by both the Tennessee and its neighbor, the Ducktown Sulphur, Copper and Iron Company. ${ }^{a}$ Both companies have succeeded in treating at a profit ore of lower grade than is mined anywhere else in the United States.

VEINS.

I visited the district in 1899 and published ${ }^{b}$ the following notes a few months later:

The ore bodies occur in veins nearly parallel to the foliation of the rocks. There is a difference in dip, and the writer has observed the vein outcrop crossing the schists at the Blue Ridge property. There has been secondary fracturing and faulting of the veins since their

\footnotetext{
a Henrich, Carl, Trans. Am. Inst. Min. Eng., vol. 25, p. 173. Kemp, J. F., Ore deposits of the United States, 1900, p. 193.

${ }^{b}$ Copper deposits of the southern United States: Trans. Am. Inst. Min. Eng., vol. 30, 1901, pp. $482-483$.
} 
formation, and the lenticular form of the deposits is ascribed by Henrich ${ }^{a}$ to these faults. The veins vary from a few feet to 150 feet in width, showing a solid mass of ore for the entire distance. They can commonly be traced for distances of a mile by surface outcrops, and the most northeasterly vein, the Burra Burra, has been followed by black copper workings for 2 miles. The observations of Henrich upon the structure and the records of the diamond-drill borings agree with the observations of Kemp and of the writer that the deposits fill fissure veins.

The ore bodies differ considerably in character. That of the Isabella mine is pyritoùs; the Burra Burra and London veins have less pyrite than the Isabella and a larger amount of chalcopyrite and pyrrhotite, while the Mary-Polk County ore is pyrrhotite with little pyrite. The copper content will average 2.2 to 3 per cent. The copper value lies in the chalcopyrite, which is scattered through the pyrrhotite in small grains and films, and more rarely occurring in bunches.

The vein consists essentially of iron sulphide for its entire width, which is 20 to 100 feet. Although the ore body is pyrrhotite it: varies in purity and value and is not always workable. This is in part due to the larger proportion of the accessory minerals in the ore or simply to a lower percentage of copper. More or less quartz in clear rounded grains, tremolite, etc., occurs in what appears to be solid pyrrhotite; and in the leaner ore these increase in amount. Bunches of white quartz are encountered in the main mass of ore and layers of slaty ore are found parallel to the walls. Hornblende ore-a mass of interlaced hornblende crystals with the open spaces between filled by sulphides-often appears along the walls.

The structural characters of these ore beds show that they fill fault fissures, which follow the foliation and correspond to slip planes between the "beds." This movement probably furnished a channel for the ore-depositing waters.

The ore body has been modified by faults since the formation of the vein, to which the present lenticular forms of the ore bodies are perhaps partly due. The ore body is thrown by these faults, and the somewhat schistose structure may be due to this and not to original replacement. The flat fractures which traverse the ore and are in some places marked by films of calcite or quartz (later than the ore) are believed to be strain cracks such as would form between two parallel shears.

The notes just given were made during a reconnaissance visit to the Ducktown district in December, 1899. 


\section{MINES.}

WEST VEIN.

The westernmost of the three large veins of the Ducktown district includes the Burra Burra, London, and East Tennessee mines. The vein is supposedly continuous between these workings, bui has not been explored except on the surface, the old black-copper workings which follow the water level being nearly continuous.

\section{BURRA BURRA MINE.}

In the Burra Burra mine the vein is very regular in course and has a well-defined and persistent hanging wall; the footwall, how-

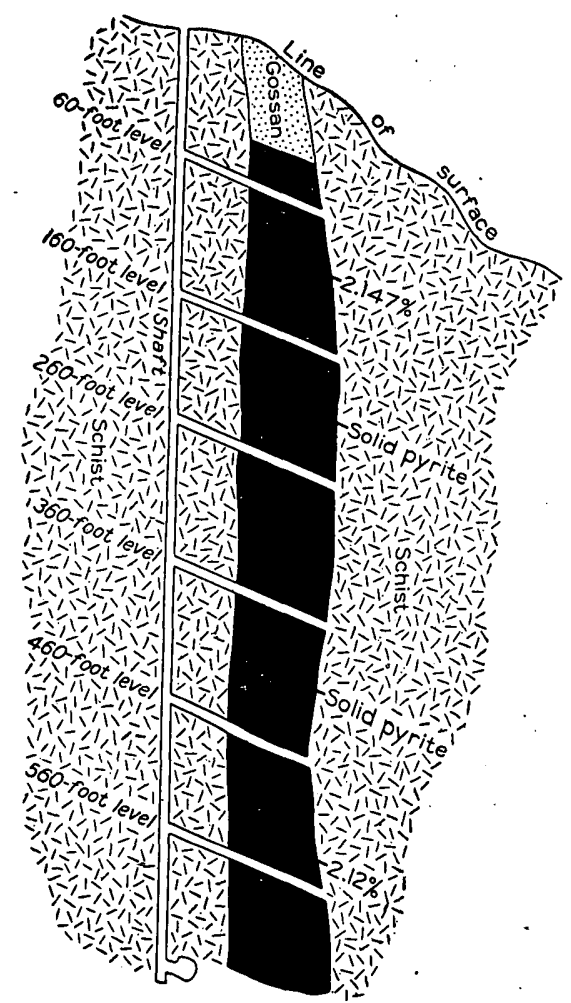

Figure 31.-Section of Burra Burra vein, Ducktown, Tenn. ever, is somewhat rolling and shows bulges, in . which the basic ore makes out in rounded bunches. This regularity of the hanging wall prevails in all three mines. Beyond the hanging wall the schist is impregnated for 100 feet or more, showing silicification and an impregnation with pyrrhotite and a little chalcopyrite. The development in the Burra Burra is 646 feet vertically beneath the outcrop on the third level; the vein has been drifted on for about 1,600 feet. To the lowest level open the dip is quite regular.

The Burra Burra and London shafts are about 4,800 feet apart, and the Burra Burra and $\mathrm{McPherson}$ are 2,000 feet apart on the strike, giving a total distance of 7,000 feet along the vein.

\section{LONDON MINE.}

In the London mine the lowest workings are on the fifth level, and the dip, which is quite constant down to the fourth level; shows a marked flattening at that point.

\section{EAST TENNESBEE MINE.}

The East Tennessee mine has been developed to 510 feet. The vein here shows a hanging-wall split, and ranges from 6 to 30 feet 
in width. The mineral character of the ore varies somewhat in different workings. In the Burra Burra mine the deposit consists essentially of pyrrhotite and pyrite in nearly equal proportions. The ore consists of about 30 per cent pyrrhotite and about 30 per cent pyrite, the balance consisting of copper and insoluble material. The London and East Tennessee ores are nearly free from pyrite, but the Burra Burra and McPherson ores carry the pyrite in isolated crystals, giving the ore a spotted or porphyritic appearance. The ore is, moreover, lower grade in this property, averaging about $2 \frac{1}{2}$ per cent. In the London mine the ore is higher grade and shows at times a casing

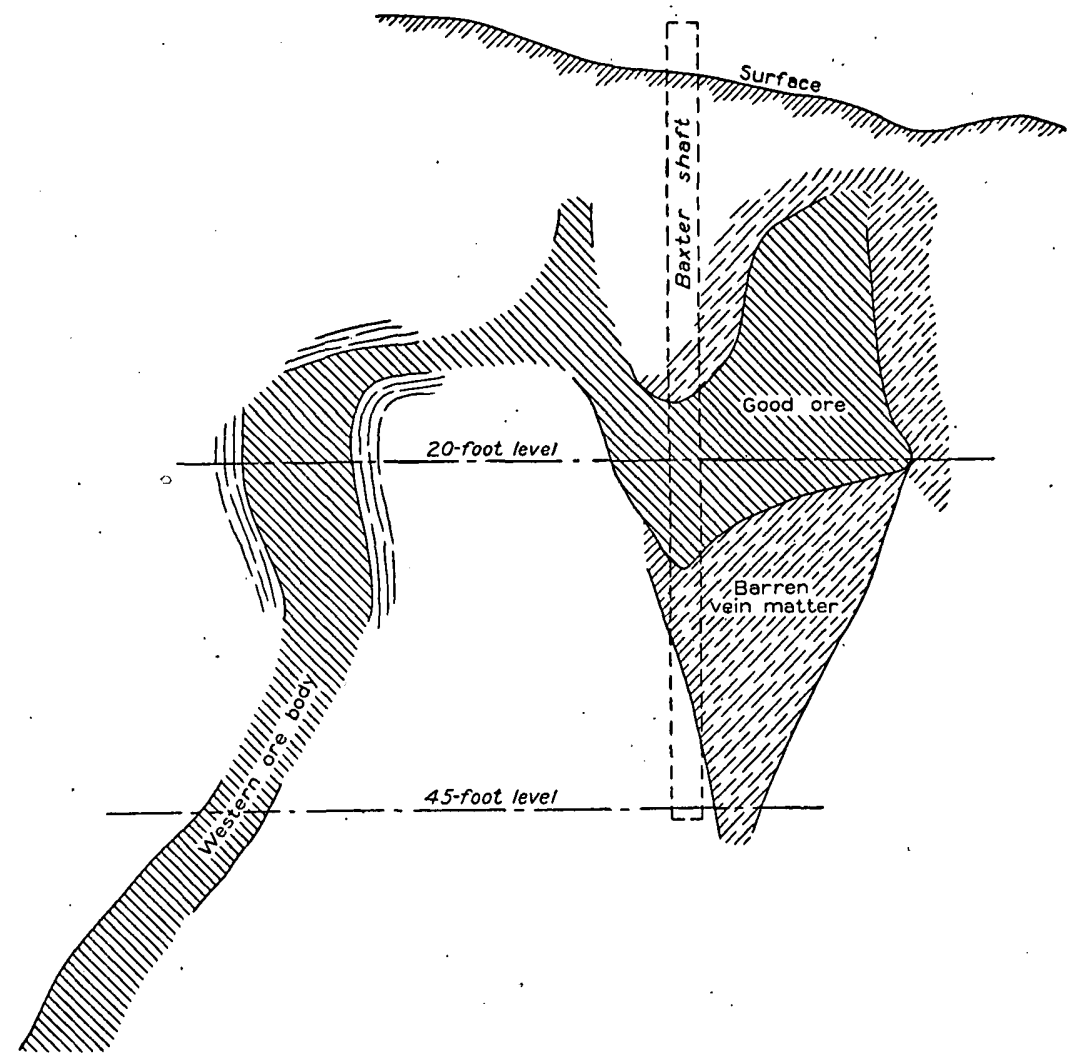

Figure 32.-Section through ore bodies of Mary mine, Ducktown, Tenn.

of siliceous ore. In general the basic ores have a somewhat blunt termination, and the fracture is apparently continued by crinkled schist. In some cases the ore pinches out and the footwall schist shows marked impregnation with chalcopyrite.

EAST VEIN.

POLK COUNTY AND MARY MINES.

The east vein contains the Polk County and Mary mines on a continuous ore body with the Callaway to the north. The crosscuts of 
the ore body are similar in both Polk County and the Mary mines (fig. 32). The deposit is irregular, and has in it horses of waste, which generally consist of a lustrous mica schist, commonly somewhat curly. One such horse showed a width of 3 to 6 feet and was 50 to 60 feet long, being entirely surrounded by solid basic ore. In general the casing of the ore body is either siliceous ore for a few inches or more or consists of purely mica schists. The hanging wall of the west ore body of the Mary vein is good. In some of the properties solid ore shows a rounded surface, slickensided and polished, and abuts directly against a sugary-white quartz-biotite schist, so that faulting is evident. The Mary vein at one place in the Polk County mine shows schists faulted against each other at an angle of $30^{\circ}$. Both the Mary and Burra Burra veins show included angular fragments of black biotite rock, which look like amphibolite in the walls but prove to be mainly biotite when seen in the daylight. In a few places balls and. stringers of ore are seen in the rock breccia adjoining the vein, and in places the ore body consists of a rock breccia in which the ore forms a cement. It is believed that the fractures are continuous for a long distance, but that in places the faulting is taken up by a crinkling of the schists. The maximum width of the Mary-Polk County vein is about 300 feet.

\section{CALLAWAY MINE.}

The Callaway mine is on the east vein, about one-half mile distant from the northeast workings of the Mary mine. The shaft is 340 feet deep, going down with an incline of $80^{\circ} \mathrm{SE}$. The ore body has a thickness of 10 to 50 feet and a developed length on the lower levels of 150 feet. The ore differs from that of the other mines in its siliceous character, showing a well-banded structure in which quartz-schist is interleaved with sulphide ore, the separate layers being from one-fourth inch to 2 inches thick. This is particularly true of the north ore body. The south ore body has a more massive texture and is basic. The walls of the ore body are of solid schist, and, as usual, show a highly and coarsely micaceous wall. Tremolite occurs in abundance, usually segregated in patches, and though a refractory silicate, is not unwelcome at the smelter save that it is usually characteristic of lean ore.

ISABELLA VEIN.

The Isabella vein lies between the Burra Burra and the Mary and continues southward in the Colchote. This is the largest ore body of the district, but is too low grade to work, carrying less than 1 per cent copper. The ore body is 250 feet wide on the level, and it is developed by underground workings and diamond-drill holes to a 
depth of 300 feet. The gossan has been worked for many years as an iron ore. The ledge to the south has old copper workings, but has not been developed.

\section{ORES.}

The enormous masses of gossan forming the outcrops of parts of the deposits, the soft rich secondary ores beneath them, and the general features of the deposits have been repeatedly described. Professor Kemp's ${ }^{a}$ paper presents the results of his carefully detailed mineralogical study of the ore.

The approximate composition of the ore from these deposits, as given by Channing, is as follows:

Mineral composition of Ducktoun ores.

\begin{tabular}{|c|c|c|}
\hline . & $\begin{array}{l}\text { Burra } \\
\text { Burra. }\end{array}$ & London. \\
\hline 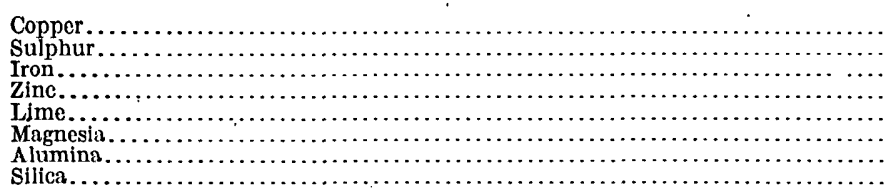 & $\begin{array}{r}2.2 \\
30.0 \\
37.5 \\
2.0 \\
6.2 \\
1.9 \\
3.9 \\
10.3\end{array}$ & $\begin{array}{r}3.0 \\
21.0 \\
31.0 \\
0.8 \\
6.1 \\
2.5 \\
4.4 \\
26.3\end{array}$ \\
\hline
\end{tabular}

The 1905 production of the Ducktown Copper, Sulphur and Iron Company was 36.4 pounds of copper per ton of ore, costing $9 \frac{1}{2}$ cents, 638,000 tons from the Mary mine, and 30,000 tons from the Callaway mine.

The characteristic mineral of the Ducktown district is zoisite, which is generally present in small crystals hardly recognizable by the eye. At times, however, it forms a gangue of considerable portions and is always welcome, as it carries a high copper content.

\section{ALABAMA.}

\section{GEOLOGY.}

The mountainous region of Alabama forms the central-eastern portion of the State. Hills of schists and other metamorphic rocks lie between the Cretaceous coastal plain on the south and the long ridges of coal-bearing Paleozoic rocks on the northwest, forming the southern continuation of the gold-bearing crystalline belt of the Carolinas and Georgia.

In this mountainous area deposits analogous to those of Ducktown are known. The so-called "copper lead" of Alabama is a strip or area of altered igneous rock, locally designated "Hillabee" schist, 
which is presumably an altered diabasic rock. This supposed lead is in no sense a lode or vein, though copper has been found in considerable amounts at different localities over its area and though the line of outcrop shows many old openings, none of which have proved profitable.

According to Smith and McCalley ${ }^{a}$ the rocks of the crystalline belt of Alabama consist of feebly crystalline or semicrystalline schists, often called talcoid schists, which are really semicrystalline slates and have been demonstrated to be metamorphosed sediments. To these the name of Talladega has been given, and they correspond in appearance and geographical position to the Ocoee of Tennessee. Carboniferous fossils (Lepidostrobus) have been found in one of the belts of this formation 8 or 10 miles from its western border. This discovery makes it certain that this belt contains infolds of Paleozoic rocks. Two-thirds of the gold workings of the State are in these Talladega slates. Along the eastern base of the range of hills known as the Talladega Mountains there is a belt of greenish rock resulting from the alteration of an igneous rock. This greenstone is called the Hillabee schist by the State survey. The outcrops of this rock have been followed from Chilton County west of Coosa River, northeastward through Coosa, Clay, and Cleburne counties to the Georgia State line. Pyrite occurs in disseminated crystals in these rocks at various intervals throughout this entire district. Crystalline pyrite in compact ore bodies also occurs at several localities.

\section{MINES.}

STONE HILL MINE.

In 1870 copper was discovered in Cleburne and Randolph counties, on the Woods Hill property, at the Stone Hill copper mine, 20 miles from Heflin station, on the Southern Railway. The property was vigorously worked during 1874,1875 , and 1876,200 to 500 men being employed in extracting and hauling the black-copper ores and nativecopper ores of the oxidized zone of the deposit, the total output being reported to have been $1,300,000$ pounds up to the time the work was stopped in 1879. For the first two years the black-copper ore alone was extracted; but this becoming exhausted in 1876, an attempt was made to mine and smelt the pyrrhotite ores. From 1879 to 1896 the property was idle, but in the latter year the Copperhill Mining Company was organized, the old mines pumped out, a new shaft house erected, machinery purchased, and mining resumed. Considerable ore was mined and stored on the surface, but no smelters were erected

"Smith, E. A., and McCalley, H., Index to the mineral resources of Alabama: Geol. Survey Alabama, 1904, p. 55. 
and, lacking railroad facilities, it was found that the ore could not be profitably worked.

According to Brewer the ore body is 24 feet thick, carrying the richest ore next to the walls with 10 feet of lean ore in the center. The entire body averages 3 per cent copper, with slight values in gold and silver. Ten feet of the ore will average 7 per cent copper. The unaltered rock of the walls appears to be a schistose igneous rock, presumably the "Hillabee" schist, though the mine is not in the main body of that formation; that is, it is not on the so-called "copper lead." a

A report on the same property made by $R$. P. Rothwell ${ }^{b}$ says that the Alabama deposit is a bed of sulphide ore intercalated in a micaceous schist of Taconic age. The vein has a limonite cap, beneath which is a black-copper zone which carries 30 per cent copper and is rarely more than 6 to 8 feet thick, the black copper following in a somewhat irregular manner the contour of the surface. The mine resembles the Ducktown and Ore Knob deposits. The openings showed 400 feet of levels, with an incline shaft running 50 feet below the levels. The bed is traceable for 1,200 feet on the surface. The schists strike N. $16^{\circ} \mathrm{E}$. and $\operatorname{dip} 45^{\circ} \mathrm{E}$. The ore occurs in welldefined beds 25 to 30 feet thick, but the wall rocks hold disseminated copper. A cross section is given, showing a central mass of slate ore with 4 to 5 feet of mundic-pyrrhotite ore on either side, lean schist ore on the hanging wall, and good schist on the footwall. The description given does not accord with that of Brewer, who says that the ore will carry 30 per cent copper, whereas the mundic contains but 3 to 4 per cent copper. The yield of the samples assayed by Adolph Thies is 5 to 40 per cent.

\section{SMITH MINE.}

The Smith copper mine lies a mile northeast of the Stone Hill mine. The ore occurs in an eruptive rock that resembles the "Hillabee "schist, but is 5 miles southeast of the main belt of that formation and is separated from it by Turkey Mountain, a hill 500 feet high, formed of graphitic slate. At the north end of the property there is an anticlinal arch, with a core of ore surrounded by alternating bands of ore and rock. The ore is thin on top of the arch and thick on the flanks, according to Brewer, from whose notes this description is abstracted. The property is now worked by the Copper Hill Mining Company. From 1870 to 1876 about $\$ 1,300,000$ worth of ore was shipped. From 1876 to 1879 the ore was smelted at a local furnace, but without profit. Since that time the property has been idle.

\footnotetext{
a Brewer, W. M., Proc. Alabama Indus. and Sci. Soc., 1897, p. 13 ; Eng. and Min. Jour., March 13, 1897, p. 256.

${ }^{b}$ Lng. and Min. Jour., vol. 24, 1877, pp. 86-88.
} 
ALABAMA PYRITES COMPANY'S PROPER'TY.

Smith and McCalley ${ }^{a}$ in 1904 described a copper property near Dean post office in Clay County, extending northeastward for several miles. The ore carries a little copper, and was first worked for this metal in the old Montgomery Copper Works, especially during the Civil War, when bluestone and other copper salts were manufactured. Recently the Alabama Pyrites Company has reopened the property. In 1904 the workings extended to a depth of 450 feet, and a daily output of 150 tons was extracted. The vein averages about 6 feet in thickness and is exposed in outcrop for $1 \frac{1}{2}$ miles. The ore as shipped contains an average of 42 per cent sulphur. A railroad has lately been completed from Talladega to Pyriton. Another bed of pyrite occurs at Hatchet Creek post office in the southwestern part of the county.

The property was visited by me in July, 1905, and found to be idle. The shafts were filled with water and the buildings boarded up. Three old shafts, unlined, and partly caved, were examined and the extensive dump heaps looked over for evidence of geologic conditions. The waste is mainly gray schist or gneiss of the hanging wall. No basic rock was seen on the dump, though bowlders of it occur on the surface, near the gossan. The ore slacks and crumbles on weathering. Various transitions from solid sulphides to country rock were observed. 


\section{INDEX,}

A. Page.

Acknowledgments to those aiding in work in New Jersey.................

Alabama, geolory and ore deposits of .... 157-160 mines of, development of............ 158-160

Sce also particular mines.

Alubama Pyrites Co. property, development of .......................

Albemarle County, Va., copper deposits of and mining development in ... 89-92

Allegheny County, N. C., copper deposits of, distribution and character of. 128-136

Allen, J. T., work of ................... 48

Ambler property, Virginia, development of.......................... 101-102

Americun mine, New Jersey, copper deposits of, occurrence and character of $\ldots \ldots \ldots \ldots \ldots \ldots \ldots \ldots, 45-54$

equipment and workings of........... 45

ores of, alteration of ................. 51-53

analyses of .................. 47-48

character and geologic relations of. 45-48 figure showing................ 40

occurrence of ................... 48-50 diagramatic sketch showing ... 49

origin of ..................... 50-54 summary of conclusions regard-

ing $\ldots \ldots \ldots \ldots \ldots \ldots \ldots \ldots .6 .53-54$

surphur content of, table showing. .

shaft of, fissures cutby, figure showing.

Amher'st County, Va., copper deposits of and mining development in........

Amphibolite dike, Virginia, course of and development work on...... 126-127

Anaconda mine, Virginia, development at. 83-84

development at, figure showing....... 84

Appalachian States, distribution of copper ores in, map showing...........

Asbestiform serpentine with native copper, from Stonyman Mountain, Va., figure showing .............

Ashe County, N. C., copper deposits of, distribution and character of .... 128-136

Avon, Conn., occurrence of cnpper at...... 35

B.

Bure Hills mine, Maryland, location, equipment, and production of ........ (64-65

Barrell, Joseph, work of ................ 47

Bartow pyrite property, Georgia, ore of occurrence and preparation of.

Bentonville-Overall district, Virginia, $\mathrm{min}$. ing development in
Berks County, Pa., occurrence of copper in. Betty Baker mine, Virginia, ore from, churacter and production of ...... 122-123

Blue Ridge regrion, Virginia, copper ores of, distribution and character of. . 93-115

geology of ...................... $95-96$ mines of, detailed descriptions of ..... 96-114 mining development in, history of..... 93-95 ores of, summary of data regárding.. 114-115 Sce also particular mines.

Blue Ridge type of copper deposits, characteristics and occurrence of .. 11, 14-15

Blue Wing mine, copper deposits of, occurrence and character of ........84-87

development $n t$.................... 84-85

figure showing $\ldots \ldots \ldots \ldots \ldots \ldots \ldots . \quad 84$

ore of, occurrence of .............. 84-87

occurrence of, figures showing..... 86,87

specimen of, figure showing.......... 85

Bond, Joseph, assistance of ............ 47

Bowers Hill, Conn., occurrence of copperin. $\quad 37$

Borg, A., analyses by ................ 47-48

Bradford County, Pa., occiurrence of copper

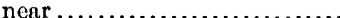

Brecciated epidotized basalt from Stonyman Mountain, Va., figure showing .....................

Bristol mine, Connecticut, copper deposits of, character of.............. 36-37

Burra Burra mine, Tennessee, development at ....................... i 154

section of vein at, figure showing...... 154

C.

Callaway mine, Tennessee, character of ore body at.

Carmel Center, Conn., occurrence of copper in........................

Carolinian type of copper deposit, characteristics and occurrence of ...... 11,13

Carroll County, Va., occurrence of copper in ......................... 115

pyrrhotite ore from, figures showing.. 120-121 Carpenter mine, Pennsylvania, copper deposit of, occurrence and character of .................... $59-61$

Catoctin type of copper deposit, characteristics and occurrence of .. $11,14-15$

Chappel mine, Virginia, development at... 83

Charlemont, Mass., occurrence of copper near ..................... $33-34$

Charlottesville, Va., occurrence of copper near........................ 90 
Cheshire, Conn., occurrence of copper in..

Chestatee property, Georgia, ore of, character and analysis of....... 149-151

development and production of....... 150

chestnut Yard, Virginia, ore from, composition of, figure showing........

pyrrhotite interleaved with talc from, figure showing ................

Eid mine, North Carolina, location of......

C'aremont, N. H., occurrence of copper at. Clay County, Ala., occurrence of copper in. Connecticut, copper ores of, distribution, character, and occurrence of... 35-37

See also particular counties and mines.

Conrad Hill mine, North Carolina, character of ore of ................ 144-1.45

Coos County, N. H., occurrence of copper in ..........................

Copper deposits, distribution of, in Appalachian States, map showing..

types of........................... 10-11

Copperfield, Vt., occurrence of copper at..

Copperfield mine, Vermont, copper deposits of, occurrence and character of .................... 24-30

See also Ely mines.

opper Knob mine, North Carolina, character of ore of ............ 132-133

copper quartz vein type of copper deposit, characteristics and occurrence of .......................... 12-13

subdivisions of .................... 11

Copper World mine, Virginia, development at.........................

Corinth, Vt., occurrence of copper at ......

Corinth mines, Vermont, development, production, and character of ore of ....................... 32-33

Cornwall, Pa., occurrence of copper near.

Cornwall iron mine, Pennsylvania, production of copper at............

Cove farm, Virginia, copper ores of, character of ................... 99-100

Cranberry mine, Virginia, development at.

Grosby, W. O., on occurrence of copper ores near Davis mine:...............

Groydon, N. H., occurrence of copper at....

Dallowhee mine, North Carolina, copper deposits of, character and occurrence of................. 138-140

development of ................... 140

Culpeper County, Va., copper deposits of and mining development in... 92-93

D.

Dahlonega, Ga., occurrence of copper near. Dark Hollow, Va., development at and character of ore at........ 107-109

Bavidson County, N.C., copper deposits of, character of................ 140-145 mining development in............ 140-145

avis mine, Massachusetts, copper deposits of, occurrence and character of .33-34

production of ........................ 3is

Dean, Ala., occurrence of copper sear..... 160
Delaware Water Gap, N. J., occurrence of copper near................ 54

Deposits of copper, classification of ....... 10-15

Diabase from Somerville, N. J., copper deposits in, plate showing .........

Dickeys Ridge district, Virginia, copper deposits of, distribution and character of .................. 99-101

Dillsburg, Pa., occurrence of copper near.. 61

Dimmicks Ferry, N. J., occurrence of copper at ......................

Dolly Hyde mine, Maryland, copper ores of, occurrence and character of.

Dorothy mine, Virginia, development at...

Ducktown, Tenn., section through Mary mine at, figure showing....... 156

Ducktown district, 'Tennessee, copper deposits of ................. 152-157

mines of, development of ........... 154-157

ores of, composition .................. 157

production of copper in :............. 157

veins of, data regarding............ 152-153

See also particular mines.

Ducktown type of copper deposit, characteristics and occurrence of..... 11-12

Durgy mine, Virginia, character of ore at.. 82 equipment and workings at, description of ...................... 82

workings at, figure showing............ 82 Dwight, W. B., on ores of Greene County, Va....................... 113-114

E.

East-central region, Pennsylvania, copper deposits of, distribution and character of.

East Tennessee mine, Tennessee, development at and character of ore of......................... 154-155

East vein, of Ducktown aistrict, Tennessee, mining development on..... 155-156

Eckel, E. C., on copper at Bowers Hill, Conn ......................... 37

Eggleston, Thomas, on Ore Knob mine, North Carolina............. 129-132

Elizabeth mine, Vermont, course of ore body at, figure showing....... 31

equipment and workings of .......... 30-31

ores of, assays, composition, and occurrence of $\ldots \ldots \ldots \ldots \ldots \ldots 21-22,31-32$

Elk Knob mine, North Carolina, copper deposits of, occurrence and character of................ 134-136

development of ................. 135-136

Elkton, Va., occurrence of copper near .. 111,113 Ellenville, N. Y., occurrence of copper near. .......................

Ely mine, Vermont, copper deposits of, occurrence and character of ..... 24-30

development of....................... 25

history of $\ldots \ldots \ldots \ldots \ldots \ldots \ldots \ldots \ldots \ldots . .24$

ores of, analyses, composition, and ocrence of ...................... 25-36

assays of ........................... 22

formation of $\ldots \ldots \ldots \ldots \ldots \ldots \ldots . . \quad 30$ 
Page.

Ely mine, Vermont, ores of, minerals of .... 29-30 petrography of ores and rocks of..... 26-30 polished specimen of ore from, plate showing ......................

production of copper at, table showing. pyrrhotite ore from, plate showing..... reduction works at, equipment of...... rocks and gangue of, minerals of ...... 26-29 schist from, plate showing

Emerion

Emerson pyrite property, Georgia, composition of rock at ..............

ore at, treatment of .

Emmons, E., on Ore Knob mine, North Carolina.....................

Emmons mine, North Carolina, develop-

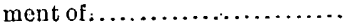

Enfield, N. H., occurrence of copper at..... Eureka mine, Vermont, development, production, and character of ore of.

\section{F.}

Finksburg, Md., occurrence of copper at... Floyd, Va,occurrence of copper near...... Floyd County, Va., occurrence oi copperin. Franklin County, Mass., occurrence of copper in

Fruser, Persifor, on copper ore near Liberty mine, Maryland........... 63-64

Frazier mine, Virginia, development at....

Frederick County, Ma., occurrence of copper in

Fritz Island, Pa., occurrence of copper at.. Front Royal, Va., occurrence of copper near .................... 93-104

Front Royal district, Virginin, copper deposits near.

\section{G.}

Gap mine, Pennsylvania, production of copper at......................

Gap Creek mine, North Carolint, character of ore of ................. 132-133

Gardners Mountain mines, New Hampshire, copper deposits of, position, occurrence, and character of..... 1ti-17

Georgia, copper deposits of, distribution and character of . $145-152$

See also particular mines.

Gold Hill district, North Carolina, coppergold deposits of............ 140-141

development of

Gold Hill mines, North Carolina, character and origin of ore of .......... 143-144

figure showing.................. 142 history of ....................... 141-142

location of ...................... 141

rock and vein phenomenn of......... 142-143

Gold Hill variety of copper deposit, characteristics of ................. 11

Gossan lead, Virginia, character of ..... 116-125 course of ......................... 116-118 dip, strike, and width of ............ 118-119 iron ore capping of, figure showing.... 122
Gossan lead, Virginia, mines along, de tailed descriptions of......... 122-124

ore of, character of .............. 119-121 composition of, figures showing.... 119,

$120,121,122$

possible future development of....... 124-125

See also particular mines.

Grafton County, Me., copper production of.

Grafton County, N. H., copper mines of, development of $\ldots \ldots \ldots \ldots \ldots \ldots, 16-18$

Granby, Conn., occurrence of copper in.... 35-36

Granville County, N. C., occurrence of copper in ....................

Greene County, Va., mining development in and character.of ores of ...... 111-111

Grayson County, Va., occurrence of copper

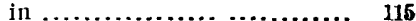

Griggstown mine, New Jers $y$, copper deposits of, char iter and occurrence of ...................4.42-44

copper deposits of, cologic relations of. $\quad 43$ location and dev' sopment of . ........ 42-43 ores of, occurre ce and che acter of ...

H.

Halifax County, Va., oc , arrence of copper jn...........................

Hanover, N. H., occ rrence of copper at... Hartford County, Conn., copper deposits of, distribution and character of... 35-37

Haverhill, N. H., occurrence of copper at.. $\quad 16$

Hawksbill Mountain, Va., mining development at.....................

Heflin, Ala., occurrence of copper near... Henrich, Carl, determination by, of composition of ore of Seminole mine, North Carolina .............. 198

High Hill mine, Virginia, development of and charucter of ore of ......... 87-89

metallic content of ore of, table showing $\quad 88$

shaft No. 4 at, occurrence of ore in, figures showing ............... 88-89

shaft No. 9 at, occurrence of ore in, figure showing ..................

Hightop Mountain property, Virginia, mining development at and character of ore of.

Higley mine, Connecticut, copper ores of, character ố ..................

Holloway mine, Virginia, development, equipment, production, and character of ore of ............ 79-81

face of 300 -foot level in, figure showing. $\quad 79$ ideal cross section in, figure showing... $\quad 79$

I.

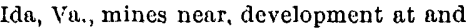
character of ore of........... 106-108

Isabella vein, of Ducktown district, Tennessee, mining development on $\ldots \ldots \ldots \ldots \ldots \ldots \ldots \ldots \ldots \ldots, 156-15$ ?

J.

Jackson County, N. C., occurrence of copper

in $\ldots \ldots \ldots \ldots \ldots \ldots \ldots \ldots \ldots \ldots \ldots \ldots \ldots . .136-140$

properties in, list of $\ldots \ldots \ldots \ldots \ldots \ldots .136-138$ 
Kieslager, characteristics and occurrence of........................ 11-12

Kirkbridge mine, Virginia; development at...................... 124

Kittatinny Mountain mine, New Jersey, copper deposits of, occurrence and character of..

See also Pahaquarry mine.

IaTor mine, North Carolina development of Laincaster County, $\mathrm{Pa}_{a}$, occurrence of copper in ......................

Lebanon, N. H., occurrence of copper at... Leesburg, Va., occurrence of copper near.. Lenticular openings, formation of, figure showing.....

Lexington, N. C., occurrence of copper near ..................... 144,

Liberty mine, Yaryland, copper deposits of, occurrence and character of....

developmentat.....................

limestone near, analysis of

Lincoln County, Ga., occurrence of copper near ..........................

Linden, Va., copper deposits near, occurrence and character of ........ 97,98

Little Tennessee mine, North Carolina, location of......................

London mine, Tennessee, workingsat......

Loudoun County, Va., copper deposits of and mining development in....

Lyman, N. H., copper mines near, development of ................... 16-17, 18

Lyman mine, New Hampshire, copper deposits of, occurrence and character of....

$M$

McKee, Capt. J. F., assistance of...........

Macon County, N. C., occurrence of copper in ...................... 136-140

Madison County, copper deposits of and mining development in ...... 10 $;-111$

Magruder mine, Georgia, ore of, character, composition, and occurrence of ....................... 145-149

development at.................... 146,

Maine, copper production of ............. 16

Manassas Gap mine, Virginia, development of and character of ore of.... 102-104

Mary mine, Tennessee, character of ore of 155-156 section through ore bodies at, figure showing .................... 156

Maryland, copper deposits of, distribution and character of ............. 62-65

Massachusetts, copper deposits of, distribution and character of .......... 33-34

Milams Gap, Va., occurrence of coppernear. Milan mine, New Hampshire, copper deposits of, occurrence and character of........................

Mills property, Virginia, copper ores of character of ............... 99-100

Mineral Hill mine, Maryland. ore of, character and $\operatorname{dip}$ of ................

Monroe County, Pa., occurrence of copper in ..........................

Montgomery County, Pa., occurrence of copper in .....................

Mount Carmel, Conn., occurrence of copper near .......................

Mount Washington, Md., Bare Hills mine at, development of .............

N.

Nantahala mine, North Carolina, character of ore at .....................

New Albany, Pa., occurrence of copper near ........................

Newgate mines, Connecticut, copper ores of, occurrence and character of ........................ $35-36$

New Hampshire, copper deposits of, character and distribution of ....... 16-18

See also particular mines.

New Haven, Conn., occurrence of copper near .........................

New Haven County, Conn., copper deposits of, distribution and character of ...........................

New Jersey, copper deposits of, distribution and character of.............. 38-57

copper deposits of, geologic relations of. $39-40$ geologic relations of, figures showing $\ldots \ldots \ldots \ldots \ldots \ldots \ldots \ldots \ldots \ldots, 40$

historical sketch of development of. $35-39$ occurrence of ................... 40-41 copper ores of, occurrence and character of

mines of, development and distribution of .......................... 42-57

See also particular mines.

New Jersey type of copper deposit, characteristics and occurrence of ......11, 13

New London, Md., occurrence of copper near.

New London mine, Maryland, copper deposits of, occurrence and character of

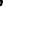

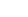

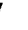

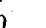
. (n) 
Paddock mine, New Hampshire, copper production of ...................

Page County, $v_{a l}$., geology of and mining development in ............. 104-107

Pahaquarry mine, New Jersey, copper deposits of, occurrence and character of ...................... 54-57

copper deposits of, geologic relations of.

development of..................... 54,57

workings at, figure showing........... 56

Pihaquarry type of copper deposit, characteristics and occurrence of ... 11,13-14

Partz, August, on copper ores near New Albany, Pa..................

Patapsco mine, Maryland, ore of, character

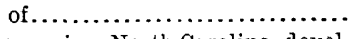

Peach Bottom mine, North Carolina, development of and character of ore of...................... 133-134

Pennsylvania, copper deposits of, distribution and character of.

enst-central region, of, copper deposits of ...........................

nortbern coal region, copper deposits of ......................... 59-61

South Mountain region, copper deposits of ......................... 57-59

occurrence of copper with other metals in .......................6. 61-62

Percival, J.G., on Cennecticut copper deposits.

Person Consolidated mines, Virginia, copper ores of, occurrence and character of $\ldots \ldots \ldots \ldots \ldots \ldots \ldots \ldots \ldots .81-82$

Person County, N.C., occurrence of copper in.........................

Piedmont Copper Co. property, Elkton, Va., ore of, character of........... 113-114

Piedmont region, Virginia, copper deposits of, distribution and character of. 67-93

copper districts of, classification of.....

See also particular mines, Virgilina district, Albemarle County, and Triassic area.

Pike County, Pa., occurrence of copper in.

Polk County mine, Tennessee, character of ore of .................... 155-156

Purpose of the investigation............. 9-10 Pyrrhotite ore, from Ely mine, Vermont, plate showing ................

\section{Q.}

Quartz lenticle of vein in Virgilina district, Virginia, figure showing .......

R.

Rappahannock County, Va., copper ores of, distribution and character of. 101-104

See also particular mines.

Rending, Pn., occurrence of copper near... 61

Rogers, W. B., on copper deposits of Virginia...................... 93,94

Rowan County, N. C., copper deposits of, character of ................ 140-145

mining development in . 140-145
Rowe, Mass., occurrence of copper in... Page.

Rudacill property, Virginia, copper ores of, character of ............. 100-191

\section{S.}

St. Lawrence County, N. Y., occurrence of copper in .....................

Salisbury, N. C., copper deposits near, occurrence of ...................

copper deposits near, rocks and vein pheriomena of .............. 142-143

Schist, from Ely mine, Vermont, plate showing.......................

Schuyler mine; New Jersey, development of ..........................

Sealoch mine, Virginia, development at and character of ore of ........... 98-99

Seminole mine, Georgin, ore of, character, composition, and occurrence of ..................... 145-149

development at

Seminole variety of copper deposit, characteristics of $\ldots \ldots \ldots \ldots \ldots \ldots \ldots$.

Simsbury mines, Connecticut, copper ores of, occurrence and character of. $35-36$

Smith mine, Alabama, development of..... 159

Somerville, N. J., copper deposits at $\mathrm{t}_{\mathrm{t}}$ diabase from, plate showing............

fissures cut by American mine shaft near, figure showing...........

occurrence of copper in contact rock near, figure showing............

section across Watchung Mountains near, figure showing .

Southington, Conn., occurrence of copper in .........................

South Mountain region, Pennsylvania, copper deposits of, distribution and character of .

South Strafiord, Vt., occurrence of copper at..........................

Southwest Mountain district, Virginia, copper deposits of and mining development in.............. 89-92

Southwest Virginia region, copper deposits of, distribution and character of..................... 115-127

dike of amphibolite in, course of and development on........... 126-127

geology of ...................... 116

gossan lead of, character of ore of ... 119-120 character of ore of, figures showing $\ldots \ldots \ldots \ldots \ldots \ldots 119,120,121,122$

course of ................... 116-119 mup showing................ 117

mines along, detailed descriptions of ....................... 121-124

Toncray deposit of, character of ..... 125-126

sce also particular mines.

Springfield mine, Maryland, production of copper at.....................

Stevensburg, Va., occurrence of copper

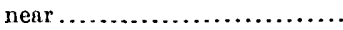

Stevenson mine, Connecticut, occurrence of copper at..................

Stokes, H. N., work of.................... 
Stone Hill nine, Alabama, deyelopment of and character of ore body of.. 158-159

Stonyman Mountain, Va, asbestiform se:pentine from, figure showing..

brecciated epidotized basalt from, figure sbowing

mining development and character of ore of 109-110

Stony Point mine, Virginia, mining development in $89-91$

Structure of veins, figure showing ......... is Sugar Run, Va., occurrence of copper at... 92 Sullivan County, N. H., occurrence of copper in...

Syliesville mine, Maryland, production of copper at.

T.

Taylors mine, Virginia, development of... Tennessee, copper deposits of, distribution and character of

See also particular mines.

Thomas mine, Virginia, character of ore at.

Thomasville, N. C., occurrence of copper near ................................ 145

Toncray deposit, Virginia, development work along ................ 125-126

Triassic area, Virginia, copper deposits of and mining development in... 92-93

Tuckaseegee copper region, North Carolina, geology, location, and important properties of.

$136-137$

mines of, development of $136-140$

U.

Ulster County, N. Y., occurrence of copper

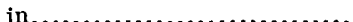

Union mine, Vermont, development, production, and character of ore of. $32-33$

Unity, N. H., occurrence of copper at...... 16

\section{V}

Vaughn mine, Virginia, development at...

Vermont, copper deposits of, occurrence and character of............. 18-33

copper deposits of, geologic relations of. $18-20$ origin of ..................... 22-23 similarity of, to other deposits ..... 23-24 copper ores of, composition and analyses of

See also particular mines.

Vershire mine, Vermont, copper deposits of, occurrence and character of.... 24-30

See also Ely mine.

Virgilina, Vr., copper mines near, development of, and character of ore of. $67-89$
Virgilina district, Virginia, copper deposits of, distribution and character of

location of .....................678 mines of, detailed descriptions of ...... $79-89$ mining development in, history of..... 68-96 ores of, occurrence and character of ... $\quad 76$ figures showing........ 82, 84; $86,87,88,89$ ore veins of, occurrence and character

of ......................... $76-79$

rocks of, age relations of............. $7 \cdot 1-7 \overline{0}$

anulyses of $\ldots \ldots \ldots \ldots \ldots \ldots \ldots \ldots, 73$

character and distribution of...... 69-i5

chemical composition of . ......... $72-74$

microscopic character of .......... $71-72$

See also particular mines.

Virgilina variety of copper deposit, characteristics of...................

Virginia, copper deposits of, distribution and character of............65-127

copper deposits of, map showing....... 66

copper districts of, classification of..... 66-67

Sce also Piedmont region, Blue Ridge region, Southwest Virginia region, and particular counties, districts, and mines.

\section{W.}

Wall mine, Virginia, development at..... $\quad \delta 2$

Warren County, Va., geology of.......... 96-97

mines of, detailed descriptions of...... 97-101 See also particular districts and mines.

Warren mine, New Hampshire, copper deposits of, position and occurrence of....................... 17

workings at, section showing .......... 17

Washington, Ga., occurrence of copper near. 145 Watchung Mountain, N. J., occurrence of copper in................. $38-40$

section across, figure showing ......... 40

Watson, T. L., on rocks of Virgilina district. $70-75$ Webster, N. C., occurrence of copper near.. $130^{\circ}$ West Fairlee, Vt., Ely mine near, development of . .................. 24-30

West vein, of Ducktown district, Tennessee, mining development on...... 154-155

Wheatfield, Pa., occurrence of copper in.... 61

Wildcat mine, Virginia, development at... 124

Wilkes County, Ga., occurrence of copper near .................... 145

Windsor Bush, Mass., copper mine at, development of

Yancey mine, Virginia, development and character of ore of ...........81-82

Yancy mine, North Carolina, assays of ore of........................ 76

York County, Pa., occurrence of copper near 